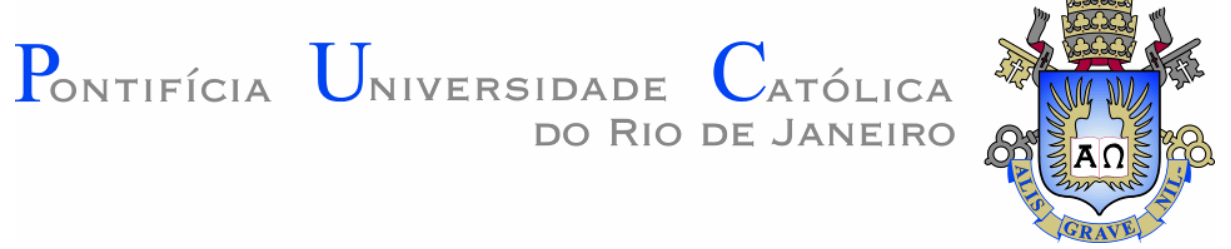

Sarah Laurindo Monteiro

Escola pública sob disputa:

moralidade e religião

Dissertação de Mestrado

Dissertação apresentada ao Programa de Pós-graduação em Ciências Sociais da PUC-Rio como requisito parcial para obtenção do grau de Mestre em Ciências Sociais.

Orientador: Prof. Marcelo Tadeu Baumann Burgos 


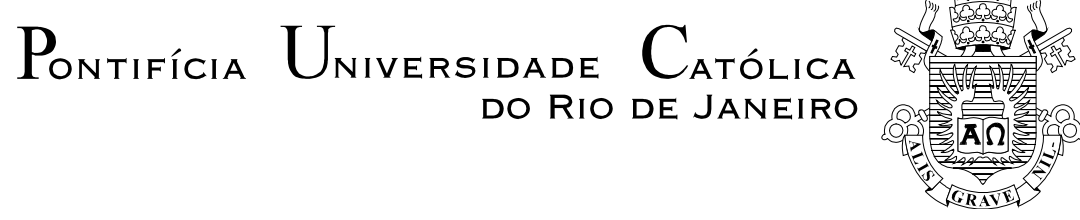

Sarah Laurindo Monteiro

\section{Escola pública sob disputa: moralidade e religião}

Dissertação apresentada como requisito parcial para obtenção do grau de Mestre pelo Programa de PósGraduação em Ciências Sociais do Departamento de Ciências Sociais do Centro de Ciências Sociais da PUC-Rio. Aprovada pela Comissão Examinadora abaixo assinada.

Prof. Marcelo Tadeu Baumann Burgos Orientador Departamento de Ciências Sociais - PUC-Rio

Profa. Cecilia Loreto Mariz UERJ

Profa. Angela Maria Randolpho Paiva Departamento de Ciências Sociais - PUC-Rio

Prof. Augusto César Pinheiro da Silva Coordenador Setorial do Centro de Ciências Sociais - PUC-Rio

Rio de Janeiro, 20 de abril de 2018. 
Todos os direitos reservados. É proibida a reprodução total ou parcial do trabalho sem a autorização da universidade, da autora e do orientador.

\section{Sarah Laurindo Monteiro}

Graduou-se em Ciências Sociais na Pontifícia Universidade Católica do Rio de Janeiro (PUC-Rio) em 2014. Foi pesquisadora do Centro de Políticas Públicas e Avaliação da Educação - CAEd/UFJF, membro do Núcleo de Estudos sobre Escola, Sociedade e Democracia (PUC-Rio). Tem interesse em Sociologia e Antropologia da Educação, da Religião, Urbana, Política e do Gênero, Infância, adolescência e Juventude e Políticas Públicas Educacionais.

Ficha Catalográfica

Monteiro, Sarah Laurindo

Escola pública sob disputa : moralidade e religião / Sarah Laurindo Monteiro ; orientador: Marcelo Tadeu Baumann Burgos. - 2018.

180 f. ; $30 \mathrm{~cm}$

Dissertação (mestrado)-Pontifícia Universidade Católica do Rio de Janeiro, Departamento de Ciências Sociais, 2018.

Inclui bibliografia

1. Ciências Sociais - Teses. 2. Religião. 3. Escola pública. 4. Laicidade. 5. Moralidade. 6. Valores. I. Burgos, Marcelo Tadeu Baumann. II. Pontifícia Universidade Católica do Rio de Janeiro. Departamento de Ciências Sociais. III. Título.

CDD:300 
À vó Elza e à vó Jacira que, às suas maneiras, entendem muito de educação e religião. 


\section{Agradecimentos}

À CAPES, por investir no conhecimento cientifico, por garantir que o trabalho de pesquisa seja feito com a tranquilidade e o tempo de dedicação que ele precisa.

À PUC-Rio, por ser a "mãe" que se diz por aí. Por ter me acolhido de braços abertos desde a graduação. Por dar os melhores subsídios para o estudo e a pesquisa, pela sua infraestrutura privilegiada e pela disposição dos seus funcionários em nos atender sempre muito solícitos. Especialmente pela Biblioteca Central e os seus bibliotecários, prestativos, pacientes e prontos a ajudar.

Ao Departamento de Ciências Sociais, minha segunda casa na cidade do Rio de Janeiro. Aos queridos professores, pelos anos de muito aprendizado e mudança de visão de mundo. Por me formarem a Cientista Social que sou hoje. Especial agradecimento aos funcionários da secretaria, Ana, Aline, Felipe e Monica, obrigada pela paciência e por resolver os problemas que sempre insistiam em aparecer.

Às professoras Angela Paiva e Cecília Mariz. Por me apresentarem o campo da Sociologia da Religião. Pelos apontamentos feitos no momento de qualificação. E por aceitarem o convite de participar da minha banca, muito obrigada pelas críticas que virão.

Ao professor Marcelo Burgos, orientador e mestre que observo e aprendo ao longo de oito anos. Por ter confiança na minha capacidade como pesquisadora. Pela intensa dedicação ao trabalho, pelo compromisso e paixão com o conhecimento. Por ter uma postura crítica e atuante na sociedade. Por instigar, desafiar e inspirar a cada dia não só a mim, como tantos outros estudantes. Por ser incansável e por vê-lo trabalhando, pensando e construindo análises e por poder 
fazer parte desse processo. Por me ensinar que as Ciências Sociais podem se construir coletivamente.

Aos amigos da turma de Mestrado de 2016, especialmente às amigas help, Tati, à Mari e à Ana, pelos bons momentos nesses dois anos.

Aos amigos do grupo de pesquisa, com carinho à Rafa, parceira dos momentos tensos e percalços para chegar até aqui, pelas conversas de grande identificação. Aos amigos da velha guarda do grupo de pesquisa, em especial ao Leo, por ser um grande incentivador e uma inspiração como profissional e pessoa.

Aos amigos do karaokê, por me fazer rir em tempos tão sombrios como o que vivemos atualmente. Às amigas madames trapo, com especial carinho, à Lah.

À minha família, ao meu pai Zezinho, por ser o maior exemplo de uma pessoa inquieta e crítica que eu conheço, por não se acomodar nunca. À Carol, por me incentivar e me botar pra cima e pelas dúvidas, à Dri, por ser a grande calmaria no meio disso tudo, por se preocupar se eu estou comendo, dormindo, me cuidando. À minha mãe Bernardete, por acreditar e apostar tanto em mim e ser o meu maior exemplo, pela sua força e garra que tanto me incentivam, por sonhar junto, por compreender as minhas escolhas. À minha família do Rio, à Socorro, que me inspira a levar a vida com mais prazer e a ser mais como eu sou, sem me importar.

Ao meu amor, Luiz, por acreditar em mim até quando eu não acreditava, por me perceber gigante, por ser com quem eu penso alto e dialogo sem hora. Pelas críticas, conselhos e sugestões para esse trabalho, por ser o organizador de ideias no quadro. Pela companhia nas madrugadas, pelas andanças na sala pra pensar, por ser o mais empolgado. Pela leitura e revisão, pelos cafés e músicas de incentivo. Pelas palavras e paciência. Por sempre estar perto e ser meu parceiro da vida. 


\section{Resumo}

Monteiro, Laurindo Sarah; Burgos, Marcelo Tadeu Baumann. Escola pública sob disputa: moralidade e religião. Rio de Janeiro, 2018. 180p. Dissertação de Mestrado - Departamento de Ciências Sociais, Pontifícia Universidade Católica do Rio de Janeiro.

O Brasil tem experimentado uma mudança no seu campo religioso com o decrescimento do catolicismo e o aumento das religiões protestantes, principalmente as de denominação pentecostal e também dos indivíduos que se declaram sem religião. Atesta-se que a sociedade está vivendo um processo de reforma moral e a escola pública é um dos seus principais palcos. Tal instituição é também o resultado de intensas disputas sociais. Esse cenário é o foco desta dissertação. Desenvolve-se, à luz dos conceitos de secularização e laicidade para compreender o processo brasileiro, em direção à constituição de uma sociedade pluralista. Isso se percebe historicamente; por meio de pistas empíricas e bibliográficas; e também a partir de propostas legislativas e resoluções para o currículo escolar recentes. É constatado que a interface entre religião e escola no Brasil é umbilical, ora aparece de forma explícita, ora subjacente nas disputas para a constituição do que se entende por escola pública. A novidade é que a transição para um campo religioso mais diverso, em especial, por conta do pentecostalismo, faz com que a naturalizada acomodação entre Estado e Igreja Católica seja abalada e se dispute o significado do próprio conceito de laicidade e até, no limite, do de democracia no cotidiano das relações que se travam no "chão da escola".

\section{Palavras-chave}

Religião; escola pública; laicidade; moralidade; valores; escola sem partido; ensino religioso; base nacional comum curricular; "ideologia de gênero". 


\section{Abstract}

Monteiro, Laurindo Sarah; Burgos, Marcelo Tadeu Baumann (Advisor). Public school under dispute: morality and religion. Rio de Janeiro, 2018. 180p. Dissertação de Mestrado - Departamento de Ciências Sociais, Pontifícia Universidade Católica do Rio de Janeiro.

Brazil has been experimenting change in their religious field with the decrease of catholicism and increase of protestant religions, especially those of pentecostal denomination, and individuals declared without religion. It is attested that society is living a process of moral reform and the public school is one of the main stages. Such institution is also, to a high degree, the result of intense social dispute. This situation is the focus of this dissertation. It is developed, under the concepts of secularization and laicity in order to understand the Brazilian process, towards the constitution of a pluralist society. It is noticed historically: through empiric clues and bibliography; also, through legislatives propositions and recent public policies. It is noted that the interface between religion and school in Brazil is intrinsic, sometimes showing explicitly, sometimes subjacent to disputes for the constitution of what is comprehended as public school. The innovation is the transition to a more diverse religious field, especially because of pentecostalism shaking the complacent situation between State and Catholic Church, thus disputing the meaning of the concept of laicity or, ultimately, that of democracy in the daily relations waged at "the schools floor".

\section{Keywords}

Religion; public school; laicity; morality; values; school without party; religious education; common basic curriculum; "gender ideology". 


\section{Sumário}

1. Introdução

2.Secularização e Laicidade: os conceitos e o caso brasileiro 22

2.1. Secular, Secularização, Secularismos 23

2.2. Laico, Laicização, Laicidades 27

2.3. Secularização sociocultural e laicidade sociopolítica 33

2.4. Secularização e laicidade no Brasil 35

2.4.1. Identidade e Sincretismo 36

2.4.2. Cidadania e Pluralismo religioso 40

2.5. Imbricações do uso dos conceitos e premissas 44

3.Católicos, protestantes, pentecostais e a

história educação brasileira 48

3.1. Colônia e Império: Jesuítas e o monopólio

da educação escolar no Brasil 49

3.2. República: disputas entre católicos e Pioneiros 52

3.2.1. As disputas entre os Pioneiros da Escola Nova e os católicos em torno da escola pública 58

3.2.2. Mais uma vez convocados: pioneiros, católicos e donos das escolas particulares em torno da Lei de Diretrizes e Bases da Educação $\quad 70$

3.3. Protestantismo e educação: o início da mudança no campo religioso brasileiro $\quad 77$

3.4. Continuidades nas disputas 88

3.5. As disputas por diferentes projetos educacionais 90

4. A disputa moral e religiosa que ocorre na escola pública contemporânea brasileira

4.1. O chão da escola: uma escola pública municipal da Zona Sul do Rio de Janeiro e algumas outras pelo Brasil $\quad 100$ 4.1.1. Dada a "maioria católica brasileira" 102

4.1.2. "Também porque a gente tem é um bom número de alunos 
evangélicos, né?"

4.1.3. "Ah, não posso fazer isso porque a minha

mãe não deixa, porque a gente vai pra igreja” 105

4.1.4. "Então, eu vejo que tem intolerância de tudo quanto é, 109 sabe?"

4.1.5. "A gente, às vezes, acaba tendo que fazer

mais o outro lado dos valores, do que é certo"

4.1.6. “'Ah, mas por que, professora, que esse feriado

existe, se nem todo mundo é católico? É uma boa pergunta, né?" 115

4.1.7. O "nós" versus "eles"

4.2. As recentes propostas legislativas e resoluções

para o currículo e a disputa moral e religiosa

120

4.2.1. Gênero e seus debates e "ideologias" 122

4.2.2. Ensino Religioso: ainda em disputa 127

4.2.3. Civismo, moral e ética 136

4.2.4. Escola sem Partido: entre conservadores e religiosos 139

4.3. A reforma moral e a mudança na cultura escolar 148

$\begin{array}{ll}\text { 5. Conclusão } & 153\end{array}$

6. Referências bibliográficas 167 
Não há mundo comum. Jamais houve. O pluralismo está conosco para sempre. Pluralismo de culturas, sim, das ideologias, das opiniões, dos sentimentos, das religiões, das paixões, mas também pluralismo das naturezas, das relações com os mundos vivos, materiais e também com os mundos espirituais. Nenhum acordo possível sobre o que compõe o mundo, sobre os seres que o habitam, que o habitaram, que devem habitá-lo. Os desacordos não são superficiais, passageiros, devidos a simples erros de pedagogia ou de comunicação, mas fundamentais. (...). O mundo comum deve ser composto, tudo está aí. Ele já não está enterrado na natureza, em um universal, dissimulado sob os véus amassados das ideologias e das crenças as quais bastaria deixar de lado para que o acordo se faça. Ele deve ser feito, deve ser criado, deve ser instaurado.

(Bruno Latour, Não há um mundo comum: é preciso compô-lo, 2011) 


\section{Introdução}

Com uma perspectiva que prioriza o olhar para os processos sociais, grande parte das vezes buscando compreender as mudanças e as continuidades, muitos são os temas que vão e voltam nas Ciências Sociais, isto é: ora tornam-se "velhos", ora são retomados com outras roupagens e ganham novos fôlegos. A relação entre Estado e religião pode ser um desses casos (Montero, 2013; Novaes, 2012). Quando globalmente assistimos a um processo de acirramento das relações entre os países europeus e a sua população mulçumana e localmente, no Brasil, percebemos atores políticos imbuídos de um discurso religioso ganhando força na arena política, tornase também nosso papel contribuir para que este novo cenário possa se tornar um pouco mais inteligível.

Já há algum tempo, estudiosos têm apontado que não podemos mais dizer que o Brasil é um país católico (Brandão, 1988; Pierucci, 2004; Teixeira, 2014; Mafra, 2013; Almeida e Barbosa, 2015 entre outros). Como se pôde ver no censo do Instituto Brasileiro de Geografia e Estatística (IBGE) de 2010, era claro o declínio contínuo do catolicismo e o crescimento de outros grupos, especialmente os evangélicos ${ }^{1}$, principalmente pentecostais ${ }^{2}$, e os sem religião ${ }^{3} .22 \%$ da população brasileira se afirmou evangélica no último censo. São 42,2 milhões de pessoas, um

\footnotetext{
${ }^{1}$ Por evangélicos entendo o universo do protestantismo como um todo. Originalmente evangelicals eram ligas e alianças de igrejas protestantes unidas por princípios comuns para fazer frente ao ultramontanismo católico. Acabou se tornando uma auto identificação no Brasil genérica para os protestantes (Mendonça, 1990). Além desse termo, tornou-se usual o uso da palavra "crente", utilizada pelos primeiros missionários para definir os convertidos. Uma divisão clássica é a do protestantismo histórico ou tradicional e pentecostal. O primeiro divide-se entre o protestantismo de imigração - ligado a uma etnicidade e a preservação da cultura de origem - e de missão principalmente norte-americanas, missões que vieram com o objetivo de converter as pessoas. metodistas, presbiterianos e batistas são alguns exemplos importantes.

${ }^{2}$ Chegou ao Brasil no início do século XX, apresentaram um boom entre os anos 1950 e 1970. Suas duas primeiras igrejas foram a Congregação Cristã do Brasil e a Assembleia de Deus. Foram um movimento de renovação entre os protestantes históricos, diferenciando-se deles inicialmente por conta do "batismo do Espírito Santo", os dons espirituais e a crença na segunda vinda de Jesus Cristo (Ramalho, 1976). Nos anos 1960, vieram as transformações desse movimento denominada por alguns de neopentecostalismo e por outros de movimento carismático (Machado, 1996). No Brasil levou a cismas nas principais igrejas históricas e surgimento de uma série de outras denominações. Uma muito importante é a Igreja Universal do Reino de Deus (IURD). Apesar da ressalva da grande pluralidade do universo protestante, em especial do pentecostalismo, para efeitos desse trabalho, usa-se o segundo termo para englobar tanto as denominações pentecostais como as neopentecostais, diferenciando-as apenas quando houver necessidade.

3 "Sem religião" não precisa necessariamente significar que não há uma crença religiosa, ou ser um sinônimo de ateísmo. Regina Novaes (2012) fala da passagem para além da vertente institucional, “em prol de uma síntese pessoal" (Novaes, 2012, p. 188).
} 
aumento de 16 milhões em 10 anos, o que dá uma média de 4384 novos fiéis por dia. Entre esse grupo, parte considerável se declarou pentecostal, são mais de dois terços dessa população, cerca de $13,3 \%$ da população brasileira como um todo, 25,3 milhões de pessoas (Teixeira, 2014). Além disso, destaca-se o retraimento, às vezes, fraco crescimento, da declaração de adeptos das religiões afro-brasileiras ${ }^{4}$ nos últimos censos. Em 2010, elas representavam 0,3\% da população (idem), embora seja digno de nota a dificuldade ainda contemporânea de estimar tais grupos, por conta dos momentos de perseguição institucionalizada que sofreram ao longo da história brasileira e que contribuem para que muitas pessoas se autodeclarem como “católicas” ou “espíritas” (Prandi, 2013 apud Teixeira, 2014).

Observamos então um processo de transição que implica em novas configurações nos valores e costumes. De um lado, tal transição merece ser problematizada. Como a formação de uma sociedade pluralista é favorecida ou não no momento em que o catolicismo deixa de ser a religião "dos brasileiros" (Teixeira, 2014, p. 37) e passa a se tornar da "maioria dos brasileiros" (idem)? Em que medida o crescimento das religiões evangélicas pode significar um aumento da pluralidade, ainda com um viés cristão e, por isso, geralmente pouco afeita a outras formas de religiosidade não-cristãs? Ou mesmo, que novos ideários são criados com o aumento das pessoas desvinculadas de uma instituição religiosa ou de uma religiosidade mais tradicional? Por outro lado, como as mudanças nas religiões dos brasileiros podem influenciar na construção de uma nova moralidade, isto é, mudar costumes, valores e atitudes?

Há um consenso de que a religião no Brasil praticamente nunca esteve restrita à esfera privada. A Igreja Católica, por exemplo, de maneira nenhuma diminuiu a sua influência política ao longo da nossa história, mesmo quando foi separada do Estado. Em contrapartida, o crescimento da bancada evangélica na Câmara e no

\footnotetext{
${ }^{4}$ Também chamadas religiões de matriz africana. "Numa definição curta (...) as religiões afrobrasileiras são basicamente religiões do transe, do sacrifício animal e do contato direto com os deuses como meio de comungar valores e estabelecer sociabilidades em comunidades relativamente pequenas" (Silva, 2011). As mais conhecidas são o Candomblé e a Umbanda. Nesse trabalho usarei a definição geral de afro-brasileiras.

${ }^{5} \mathrm{Um}$ grande exemplo é o de Mãe Menininha do Gantois, célebre mãe de santo baiana que morreu em 1986. Dizia ao agente do censo "sou católica". Em contrapartida, mais recentemente para o censo de 2010, houve campanha do movimento negro e também de instituições de religiões de matrizes africanas para incentivar a auto declaração a tais denominações com o slogan "Quem é de Axé diz que é!”.
} 
Senado Federal e até a eleição do prefeito da cidade do Rio de Janeiro em 2016, Marcelo Crivella, ligado à Igreja Universal do Reino de Deus (IURD), demonstram um crescente poder político de diferentes igrejas evangélicas.

Para além da relação entre Estado e Igrejas e Política e Religião, torna-se de especial relevância ao trabalho, atentar-se mais especificamente para as interfaces entre a escola pública, moralidade e religiões. Inúmeras notícias a ilustram, algumas delas se destacam por evidenciar como tal relação é geralmente perpassada por diferenças e conflitos. Situações essas que foram descortinadas por conta da nova realidade religiosa brasileira. Algumas ocorridas fora do ambiente escolar, ainda assim muito importantes para o que nos interessa aqui: a situação enunciada por Vagner Gonçalves Silva (2007), a exposição da imagem do adolescente Ricardo Navarro, no livro de 1997, Orixás, Caboclos \& Guias - Deuses ou Demônios? de Edir Macedo, bispo fundador da IURD. Então com 4 anos, ele apareceu numa foto tocando atabaque no terreiro de sua avó, a Ialorixá Palmira de Iansã, em Mesquita, no Rio de Janeiro, com a seguinte legenda: "essas crianças, por terem sido envolvidas com os Orixás, certamente não terão boas notas na escola e serão filhos 'problemas' na adolescência". Antes disso, outras três crianças foram utilizadas em imagens que aparecem na Folha Universal, numa matéria cujo título era "Filhos do Demônio". Uma delas disse ter sido motivo de chacota na escola, "eu fui chamada de macumbeira, que vivia em religião de demônio" (Silva, 2007, p. 21) ${ }^{6}$.

O caso de Kayllane dos Santos, já citado em diversos trabalhos (Zeferino, 2016; Rodrigues, 2017), uma menina de 11 anos que foi apedrejada ao sair de uma cerimônia do Candomblé em um subúrbio carioca em 20157; na cidade de Dourados, no Mato Grosso do Sul, em 2017, foi realizada uma audiência pública para responsáveis pedagógicos de alunos da rede pública sobre evasão escolar que acabou se tornando uma pregação "motivacional e religiosa". O procurador de

\footnotetext{
${ }^{6} \mathrm{Na}$ Bahia, a Justiça pediu que tal livro fosse retirado de circulação pelo seu caráter ofensivo às religiões afro-brasileiras. No Rio de Janeiro, a IURD e a editora Gráfica Universal foram condenadas em 2004, a pagar 120 mil reais pelo uso indevido da imagem de Ricardo Navarro. Foi aberto outro processo em relação às três crianças, a gráfica foi condenada a pagar 20 salários mínimos para as famílias delas (Silva, 2007, p. 21).

${ }^{7}$ Disponível em http://g1.globo.com/pop-arte/blog/yvonne-maggie/post/menina-apedrejadafanatismo-e-intolerancia-religiosa-no-rio-de-janeiro.html. Acesso em: 14 fev. 2018. À época, à coordenadoria de ensino religioso da Secretaria Municipal de educação promoveu uma atividade em que os alunos escreveram cartas para Kayllane. Para uma análise crítica dessa atividade ver: Zeferino, 2016.
} 
justiça responsável falou sobre a "necessidade de Deus nas famílias", fez orações e condenou a discussão sobre gênero nas escolas por meio de vídeos ${ }^{8}$.

Outras, que se deram nas escolas públicas propriamente: a situação de um menino que se iniciava no Candomblé, que em 2014, então com 12 anos, foi barrado na entrada pela diretora da escola municipal onde estudava, localizada na zona norte da cidade do Rio de Janeiro. O motivo era o fato de o garoto ter que usar branco e guias durante 3 meses como parte do ritual de iniciação, e mesmo vestindo a blusa de uniforme por cima, a diretora disse que suas roupas estavam "fora do padrão adequado". Ele acabou ficando quase um mês sem ir para escola, só retomou quando foi transferido de unidade ${ }^{9}$.

Em Salvador em 2005, uma diretora de uma escola pública pediu que apagassem a figura do Orixá Ogum que tinha sido feita num painel artístico naquela escola, por conta da pressão dos pais evangélicos (Silva, 2007, p, 15); ou ainda, a ocorrida numa escola pública estadual de Manaus, em 2012, quando 13 alunos se recusaram a fazer uma atividade sobre cultura africana, alegaram que tal tarefa ia contra os seus princípios religiosos e, por isso, fizeram um trabalho alternativo sobre as missões evangélicas na África, orientados pelos seus pais e pastores ${ }^{10}$.

Há o relato também dos protestos de uma coordenadora pedagógica evangélica de Belford Roxo, no Rio de Janeiro, contra uma editora de uma série de livros didáticos que, ao falar sobre as "raízes africanas", explicava as religiões afro-brasileiras. Para a coordenadora, fazia-se uma "apologia" a elas, o que fez com que os livros não fossem adotados na escola em que trabalhava, uma vez que a maioria dos alunos e

${ }^{8}$ Foi feita uma convocação obrigatória aos pais e responsáveis pedagógicos dos estudantes. Disponível em http://justificando.cartacapital.com.br/2017/05/27/ministerio-publico-do-mscoagiu-pais-irem-em-palestra-com-pregacao-religiosa/ . Acesso em: 27 mai. 2017.

${ }^{9}$ Disponível em: https://educacao.uol.com.br/noticias/2014/09/03/rj-aluno-e-impedido-defrequentar-escola-com-guias-de-candomble.htm e http://g1.globo.com/rio-dejaneiro/noticia/2014/09/aluno-e-barrado-em-escola-municipal-do-rio-por-usar-guias-docandomble.html . Acesso em: 14 fev. 2018. O então prefeito Eduardo Paes fez um pedido de desculpas ao aluno e à sua mãe e abriu uma sindicância contra a diretora. Ver: https://oglobo.globo.com/rio/paes-recebe-aluno-barrado-em-escola-no-rio-por-usar-guia-docandomble-13815666. Acesso em: 14 fev. 2018.

${ }^{10}$ Para tentar resolver a situação foi proposta uma reunião com os responsáveis pelos alunos, a escola e entidades de Direitos Humanos, LGBTs, o Fórum de Diversidade da Ordem dos Advogados do Brasil daquele estado e o Ministério Público Disponível em: http://www.pavablog.com/2012/11/12/em-manaus-alunos-evangelicos-se-recusam-a-ler-obrascomo-macunaima-e-casa-grande-senzala-dizendo-que-os-livros-falam-sobre-homossexualismo/. Acesso em: 09 dez. 2016. 
professores ali eram evangélicos, apesar da escola ser laica e pública, e da Lei $10.639^{11}$; e, ainda em Pato Branco, no Paraná, um vereador evangélico classificou tal obra como "livro do demônio" e pediu a "cassação" da coleção (Silva, 2007, p. $17)^{12}$.

Também foi publicizida a situação trazida por Stela Guedes Caputo (2012), ocorrida em 2009, de uma professora umbandista da rede municipal do Rio de Janeiro que foi proibida pela diretora evangélica de dar aulas em uma escola, porque utilizava o livro Lendas de Exu. A alegação de algumas mães de alunos era que se fazia com isso, "apologia ao Diabo" (Caputo, 2012, p. 246). Envolvendo igualmente o uso de livros didáticos, no início de 2017 na cidade de Ji-Paraná em Rondônia, um grupo de pais e mães de uma escola pública estadual entregou um abaixo-assinado ao Ministério Público daquele estado pedindo a retirada do livro de ciências do nono ano do Ensino Fundamental por conter um capítulo sobre educação sexual que possuía um desenho de um órgão sexual masculino, o que foi considerado "impróprio" por eles ${ }^{13}$.

Esses são alguns dos acontecimentos que foram elencados, poderiam ser muitos outros. Uma certeza se tem: eles ocorrem. Têm em comum o envolvimento de estudantes - crianças ou jovens - de escolas públicas, professores, gestores e/ou responsáveis pedagógicos - principalmente mães; o alvo nas pessoas e nas crenças das religiões afro-brasileiras, como também num determinado tipo de moralidade. Outrossim, têm como autores, principalmente, os evangélicos. Ocorrem, no entanto, num contexto mais amplo de "solo católico" (Giumbelli, 2007, p. 175), isto é, numa base que dá um caráter de invisibilidade ao catolicismo no Brasil.

\footnotetext{
${ }^{11}$ Essa é uma lei de 2003 que prevê "no âmbito de todo o currículo escolar, em especial nas áreas de Educação Artística e da Literatura e História brasileiras" a obrigatoriedade do ensino da História e da cultura afro-brasileiras nas escolas de ensino básico públicas e privadas. Em 2008, ela foi alterada, acrescentando o estudo da cultura e da História indígena também como parte do currículo oficial. Posteriormente, nas Diretrizes Curriculares Nacionais publicadas em 2013 tal lei foi regulamentada. Propôs-se entre outras coisas, a valorização e o respeito às religiões de raiz africana (DCN, 2013, p. 499), o incentivo ao diálogo intercultural de valores, visões de mundo, raciocínios e pensamentos. Fala ainda da possibilidade de parcerias com organizações negras incluídas as irmandades religiosas. Especificamente no conteúdo de História fala-se da inclusão da história da ancestralidade e religiosidade africana.

${ }^{12}$ Ainda segundo Silva, a coleção havia sido avaliada e obteve parecer muito favorável, sendo então recomendada pelo Guia do Plano Nacional do Livro Didático (PNLD-2004).

${ }^{13}$ Disponível em: https://brasil.elpais.com/brasil/2017/04/17/opinion/1492435392_872941.html . Acesso em: 14 fev. 2018.
} 
A escola pública, alçada como uma instituição central a partir da Constituição de 1988 para a socialização das novas gerações (Burgos, 2014), passa a ser um lugar de disputa; uma vez que se discute, a partir desse momento, que tipo de escola que se quer preconizar. No limite, a disputa em relação à escola explicita qual o projeto de sociedade que se quer apostar. Nesse sentido, esta é uma tarefa que não é mais só dos sistemas escolares e da comunidade escolar. É compartilhada e se torna responsabilidade da sociedade como um todo em seus diferentes grupos, desde as famílias até as instituições organizadas, desde a Universidade até as diferentes entidades de proteção à infância e à adolescência, desde a mídia até os partidos e as próprias instituições religiosas. Importa à dissertação entender tal disputa dando enfoque nas diferentes religiões em relação aos currículos escolares e também à prática de professores no tocante a alunos do segundo segmento do Ensino Fundamental, isto é, adolescentes geralmente entre 11 e 15 anos de idade. Percebendo ainda de que modo categorias como a laicidade, a tolerância e a diversidade são acionadas ou não. Nesse sentido, busca-se voltar a atenção para as relações entre o espaço público e o privado, em diferentes visões de mundo, valores, atitudes e moralidades que ora se relacionam e ora concorrem umas com a outras dentro do ambiente escolar.

Minha aproximação com o tema se deu a partir da realização de um trabalho de campo em duas escolas públicas em Goiás no ano de $2014^{14}$. Oportunidade em que, apesar de não ser esse o meu foco, passei por um momento em que o campo "gritou" aos meus olhos de pesquisadora, ou como disse José Guilherme Magnani (2009), tive uma "experiência reveladora" (Magnani, 2009, p. 149), que só o encontro das teorias do pesquisador com as ideias nativas pode produzir (Peirano, 1995, apud Magnani, 2009). Revelou-se um dado que para mim era novo: a permeabilidade de determinados valores, por vezes religiosos, que adentravam o ambiente escolar com bastante naturalidade. Abriu-se um mundo de novas questões que me permitiram rever a hipótese de uma escola pública republicana, consequentemente laica, e dar novas pistas para construir o argumento deste trabalho.

\footnotetext{
${ }^{14}$ Intitulada "Educação para o mundo do trabalho", esta foi uma pesquisa financiada pela Confederação Nacional das Indústrias $(\mathrm{CNI})$ e realizada pelo Centro de Políticas Públicas e Avaliação da Educação (CAEd/UFJF). Buscava compreender as estratégias de escolas públicas em todas as regiões do Brasil que tinham tido o maior salto em seus resultados no Índice de Desenvolvimento da Educação Básica (IDEB) entre os anos de 2011 e 2013. Eu havia ficado responsável em pesquisar as duas melhores escolas da região centro-oeste.
} 
Na primeira delas, em Goiânia, presenciei uma atividade extracurricular para adolescentes com idade entre 11 e 15 anos. Foi uma palestra com uma pessoa, aparentemente famosa na região, que ia de escola em escola para falar sobre bullying e drogas com as crianças e os adolescentes. O palestrante falou sobre como é a vida de um preso, sua rotina, os castigos e a comida ruim. Mostrou imagens de adolescentes usando drogas, disse que a escolha era deles. Falou também sobre doenças sexualmente transmissíveis, responsabilizando apenas as meninas pelo uso da camisinha. Também sobre o aborto contando para os alunos presentes a história de um feto ao ser abortado. Em outra hora, pediu aos alunos que fechassem os olhos e desenvolveu uma história onde a mãe de cada um havia morrido, pediu a eles que pensassem o que sentiriam se isso acontecesse, o que diriam às suas mães se tivessem uma última oportunidade. A palestra seguiu, "coloque Deus no seu coração acima de tudo" ${ }^{15}$.

Na segunda escola presenciei uma reunião de pais e responsáveis dos alunos iniciada com uma oração. Em outro momento foi falado sobre o "momento de acolhida", um acontecimento que ocorre todos os dias na escola antes que a aula comece. Todos os alunos são enfileirados no pátio junto aos funcionários, fazem orações, participam do momento de socialização e, por último, cantam o hino nacional. Essa é uma forma dos alunos aprenderem a se comportar e melhorarem a disciplina dentro da própria sala de aula. Iniciam o "momento de acolhida" com a seguinte frase: "vamos nos colocar na presença de Deus, pedir as bênçãos do Senhor" e depois rezam o "pai-nosso", como forma de respeitar as outras religiões, o "pai-nosso é quase universal"".

Foram essas duas situações de campo que me impulsionaram a pensar a escola pública a partir da sua porosidade à religião. Muitas vezes, ela não aparece tão claramente, mas envolta em uma perspectiva de ensino de "valores", como sendo

\footnotetext{
${ }^{15}$ Maria Edir Silva (2011) observa em outra escola pública o desejo dos evangélicos em ver o pastor conduzindo reuniões, hinos de louvor em momentos previstos no calendário escolar. E Allan do Carmo Silva (2013) registra a entrada de uma pastora evangélica para realizar orações para alunos e funcionários em uma escola pública.

${ }^{16}$ Outras situações de pesquisa em que foi observado momentos de oração em escolas públicas: Silva (2011), uma escola que criou uma oração própria que atendia evangélicos, católicos e espíritas: durante o "pai-nosso" todos rezavam, no "santo-anjo" os evangélicos se dispersavam e na oração espírita a dispersão era quase geral; Cunha (2013) observa numa escola que a refeição só começava após uma oração coletiva; Zeferino (2016) registra numa escola pública a realização de orações após a execução do hino nacional em momentos coletivos.
} 
uma aliada à disciplina, a um determinado tipo de comportamento e de estilo de vida. Corrobora uma expectativa de um aluno ideal e de uma família também ideal, segundo determinados preceitos.

Outra motivação, esta que segue a linha observada por Gilberto Velho (1978) de "estranhar o familiar", tem a ver com a surpresa percebida de uma classe média mais intelectualizada, na qual me incluo, com o crescente ganho de força política de candidatos que se dizem evangélicos ou que se aproximam dos seus valores. A primeira reação ao novo cenário geralmente foi o de se valer da ideia do Estado laico. Porém, ao estranhar a minha própria formação em uma família extremamente católica foi que percebi que o "casamento" entre religião e política já existia no Brasil desde a sua fundação e que, muitas vezes, não era tão fortemente questionado, ao contrário, era naturalizado. Por que isso não incomodava tanto assim antes?

A diferença agora é que, pela primeira vez, o cenário se consolidava não mais como uma hegemonia da Igreja Católica. Passou-se a se constituir o que se convencionou chamar de um "mercado religioso brasileiro". Esse que é acirrado com a disputa principalmente dessa igreja com as denominações pentecostais, materializada principalmente nas arenas político-partidária e midiática (Mariano, 2011) e, porque não dizer, também no próprio mundo da vida, já que a religião é tão presente no dia a dia das pessoas. Como observam Christina Vital da Cunha e Paulo Victor Leite Lopes (2012), ter como objeto privilegiado os evangélicos, torna-se interessante na medida em que a presença deles trouxe visibilidade para velhas questões e atores antes pouco percebidos. Além de destacar situações em que quase não se conseguia ter alguma legitimidade para colocar em questão a laicidade até então em espaços como o Judiciário, as Assembleias Legislativas e as Câmaras, os hospitais, os asilos, e as escolas públicas.

Busca-se compreender como a escola pública brasileira passa a experimentar as disputas que se dão a partir das mudanças no campo religioso brasileiro. A hipótese geral deste trabalho é a de que vivemos um processo de transição de uma sociedade hierarquicamente sincrética (Mariano, 2011 apud Freston, 1993), isto é, que se vale de combinações entre diferentes religiões, mas que só dá o status ao catolicismo, para uma sociedade pluralista (Montero, 2015). Entretanto, tal transição ainda não 
se deu plenamente, pois as diferentes religiões experimentam lugares de poder desiguais no espaço público, o que se pode traduzir numa perpetuação de uma exclusão já histórica principalmente para os adeptos das religiões minoritárias, como as afro-brasileiras. Isso, num momento em que elas passam a ser tornar visíveis nas escolas por meio, por exemplo, da inserção no currículo do ensino de história e cultura afro-brasileira e africana. Tudo isso, sem perder de vista o caráter de invisibilidade do catolicismo construído historicamente e, ainda hoje, fortemente presente na sociedade e na cultura brasileira, apesar do seu vertiginoso decrescimento em adeptos nos últimos anos.

A segunda hipótese é a de que o aumento da força social e política das religiões evangélicas, principalmente as pentecostais, fazem com que se tornem visíveis (Vital da Cunha e Lopes, 2012), mais do que isso, presentes e "perturbem" arranjos até então acomodados como o da porosidade da escola pública brasileira ao catolicismo. Como seus atores - professores, diretores, alunos e famílias comportam-se na medida em que tal sociedade apresenta uma concepção diferente da anterior? Por último, supõe-se que também no espaço da escola exista uma disputa que se manifesta nas diferentes perspectivas trazidas por uma nova normatividade a partir da Constituição de 1988, de Estado laico e liberdade religiosa que se chocam com as diferentes visões de seus profissionais, alunos e suas famílias. E que há uma moralidade latente no ambiente escolar que preconiza o ensino de "valores" mais ou menos relacionados a um "fundo" religioso.

Para tanto, desenvolvem-se três capítulos. O primeiro deles versa sobre os conceitos de secularização e laicidade. A fim de traçar as tradições teóricas que os definem e as suas diferenças. Além disso, discute especificamente o processo brasileiro de definição da laicidade estatal a partir da República e sua relação contínua com o catolicismo, o tipo de construção social e cultural do secular e ainda as mudanças advindas do crescimento das igrejas evangélicas. O capítulo que se segue a esse, busca compreender a história social e cultural da escola pública brasileira, dando ênfase na sua relação com o catolicismo a partir dos jesuítas e posteriormente com os Pioneiros da Escola Nova. Como também, aprofundando na história dos protestantismos e pentecostalismos e sua relação com a educação escolar. 
O último capítulo traz situações contemporâneas que envolvem a moralidade e as religiões que adentram o ambiente escolar público no seu cotidiano em dois níveis observáveis: o do "chão da escola", por meio de uma pesquisa empírica exploratória em uma escola pública municipal da cidade Rio de Janeiro; como também, a partir de propostas legislativas e resoluções para o currículo recentes, a saber, as discussões relacionadas ao gênero e à diversidade sexual e também sobre o Ensino Religioso na Base Nacional Comum Curricular (BNCC) e as propostas legislativas sobre Moral e Cívica e o Programa Escola sem Partido (ESP). Desse modo, tem-se a possibilidade de perceber que essa disputa não é nova e, ao mesmo tempo, traçar as suas diferenças e aproximações do contemporâneo - com o pluralismo religioso em curso - com o período anterior - de hegemonia católica. Aposta-se na escola pública como um bom palco de análise. 


\section{2}

\section{Secularização e Laicidade: os conceitos e o caso brasileiro}

A laicidade, enquanto valor a ser cultivado como tradução axiológica da separação entre Estado e Igreja, é comumente lembrada quando se percebe uma interpenetração das duas esferas em diversas instâncias, como: quando persistem símbolos religiosos em repartições públicas; quando se faz referência a algum ritual religioso em sessões legislativas; ou quando se instituem e se multiplicam os feriados desta ou daquela religião. Nenhum lugar talvez seja mais sensível a este valor quanto a escola pública. Essa instituição, mais do que outros espaços, é uma referência de tal separação.

Sempre poderemos nos reportar à Constituição e afirmar que "o Estado é laico" quando situações como as citadas ocorrem. No entanto, para efeitos deste trabalho, faz-se necessária uma aproximação atenta à construção sociológica da laicidade enquanto conceito. Antes disso, precisamos nos deter na discussão sobre o conceito de secularização. Uma vez que ambos se relacionam intimamente. A secularização é um processo mais abrangente e tem a ver diretamente com a Modernidade, uma vez que é nesse período, no Ocidente, que se realiza a retirada da influência da religião em vários aspectos da vida individual e social.

Quais são os seus fundamentos filosóficos? A que contexto especifico se referem? Como se conectam e como se diferenciam? Como se deu tais processos no Brasil? Esta já é uma discussão clássica, nunca é demais revisitá-la para, enfim, delimitar o percurso a ser construído. Ricardo Mariano (2011) esclarece que o uso do termo secularização e suas derivações se dá em grande medida na literatura em alemão e inglês. Nos escritos em português, espanhol e francês o termo é dividido com laicidade e seus correlatos. Uma hipótese para tal distinção é a necessidade de se delimitar claramente como um dispositivo jurídico a separação do Estado em relação à Igreja em países latinos de tradição católica, casos mais acirrados quando comparados aos contextos de países anglo-saxões de tradição protestante. Alguma confusão pode ser gerada, pois, muitas vezes, os dois conceitos são utilizados como sinônimos, apesar da diferenciação latina. 
"Laico", originalmente do grego, laikos, significa "do povo", de onde vem laos, que quer dizer "povo". Era utilizado inicialmente para distinguir os cristãos que não faziam parte do clero, não eram padres, bispos ou diáconos (Blancarte, 2011). Exibe um sentido próximo do que para nós hoje significa "leigo". Somente no século XIX que essa palavra passa a denotar um espaço que está fora do controle eclesiástico. Já o termo "secular" deriva de saculum e também significou primeiramente o grupo de membros da Igreja que não pertenciam ao clero (idem). Embora hoje tenha havido um descolamento do sentido original e tenham ganhado novos significados, opondo-se inclusive ao religioso, como Roberto Blancarte destaca, as duas palavras têm uma origem religiosa e especificamente cristã.

\section{1}

\section{Secular, Secularização, Secularismos}

Com sua visão crítica diante da Modernidade, Weber (1982) foi um dos pensadores que falou na separação da esfera religiosa diante das outras. Tal separação se caracteriza por dois aspectos: a diferenciação da esfera religiosa, econômica, política, estética, erótica e intelectual, detenho-me mais à frente em algumas delas; como também, o seu crescente processo de racionalização. Inicialmente, para Weber, nas próprias religiões pode-se ver um processo de rejeição do mundo e de renúncia das coisas mundanas. Ele se utiliza de duas categorias que funcionam como polares e que se traduzem em diferentes comportamentos visando à salvação: o ascetismo e o misticismo. No primeiro caso, o devoto é visto como instrumento de Deus e, por isso, se prova através da ação, por meio do trabalho como uma vocação "mundana"; já no segundo, o indivíduo é tido como "recipiente" do divino, nesse sentido, o objetivo que se tem é o da possessão contemplativa, volta-se então para o "outro mundo" e não para este.

Em contrapartida, as práticas mágicas são aproximadas a um tipo de carisma que tem nas figuras do profeta e do salvador o seu ápice. Weber afirma que as tensões entre religião e o mundo aumentam na medida em que elas se tornam cada vez mais redentoras. Uma vez que os ensinamentos proféticos evoluíam para uma ética, e ainda mais se essa ética era cada vez mais racional, e quanto mais se voltasse para valores sagrados interiores, a tensão seria crescente. Ao mesmo tempo, tal processo 
de racionalização e de sublimação possibilitavam a tomada de consciência de uma autonomia interior e lícita, como Weber coloca, das esferas individuais.

A ética religiosa desenvolveu-se a partir de uma perspectiva de "amor ao sofredor per se" (caritas): ajuda ao vizinho em dificuldade e o pensamento de que a necessidade de um hoje pode ser a do outro amanhã. Uma fraternidade que cada vez mais se chocaria com os valores do mundo, que se racionalizava e firmava as suas próprias leis. No caso da esfera econômica, diz Weber, isso foi mais evidente. Interesse, mercado, lucro e acúmulo são características que definitivamente não se encaixam com a ideia de amor ao próximo. Uma saída para isso foi a da ética puritana da "vocação", o trabalho como serviço da vontade de Deus e uma comprovação do estado de graça; outra, ligada ao misticismo, em que a devoção é o fim e não é dirigida a ninguém em especifico, como também o próprio sacrifício assim é feito.

Outra esfera citada por ele é a política. Surge uma tensão quando se entende o Estado a partir do monopólio do uso legítimo da violência e, por isso, é ele quem administra as questões, as punições e que tem o objetivo de salvaguardar a distribuição interna e externa de poder. Política e religião podem concorrer diretamente. A saída puritana é afirmar que os mandamentos de Deus são incompreensíveis e devem ser impostos ao mundo pelos seus próprios meios, ou seja, a violência. A fraternidade é resguardada então apenas nos interesses e "causas" especificas de Deus. O misticismo, por sua vez, prega uma atitude antipolítica radical, separa-se do estigma da violência. A busca pela salvação pode ser resumida pela frase bíblica: “dai a César o que é de César”, nesse sentido completamente à parte do mundo. No entanto, as religiões históricas, diz Weber, se misturam com os interesses e lutas pelo poder.

Por último, importa citar a emancipação da esfera intelectual. Caso o conhecimento racional, isto é, o desencantamento, se dê por meio da sua transformação de um mecanismo causal para significar que o mundo é um cosmo ordenado por Deus, então não há tensão, pois dessa forma o caminho chega à religião. Quando, ao contrário, não há essa conciliação, mais uma vez temos uma concorrência de duas visões diferentes de mundo que se pretendem últimas. E se há uma luta com a 
ciência, ela também se dá no campo da educação dos mais jovens mais à frente ${ }^{17}$. Para cada esfera há ações que seguem leis próprias e, por isso, inevitavelmente entram em tensão com a ética religiosa. Para os religiosos, as coisas mundanas foram sendo cada vez menos valorizadas e tidas como fúteis, afinal estar aqui era tido como indigno e provisório e o que de fato importava era a busca pela salvação ou a sua demonstração.

Charles Taylor em seu Uma Era Secular (2010) busca compreender o termo analítico secularização para além da ideia de separação da Igreja em relação às estruturas políticas, ou mesmo a partir da constatação corrente, principalmente na Europa central, do declínio e/ou abandono das práticas religiosas, em parte pelo aparecimento de outras crenças, como a ciência e a razão. Seu argumento pode ser resumido na percepção da mudança de uma sociedade em que a fé em Deus era inquestionável para outra em que essa se torna apenas uma alternativa, uma opção ou uma possibilidade dentre tantas outras. É claro, diz ele, que o primeiro sentido contribuiu para que este último ocorresse, mas tal transformação envolve mais do que o Estado ou o espaço público. A plenitude da vida humana deixa de ser transcendente e passa a ser imanente, isto é, realiza-se "dentro" e não "fora" da vida.

Para Taylor, importa perceber então o movimento da Modernidade como que possibilitando novas condições de crença, na medida em que a religião ocupa um novo lugar na vida social, mais ou menos ligado ao mundo privado. $\mathrm{O}$ autor corrobora com a tese de Weber sobre diferenciação e autonomização das esferas e destaca a não necessidade de exclusão da fé para que ocorra um processo de racionalização. Weber já havia falado também, ao enfatizar a intelectualização das religiões a partir de suas próprias teodiceias e seus distanciamentos em relação à magia, Taylor chama atenção que muitas vezes se confundiu o desencantamento do mundo com o declínio da religião, o que termina por abafar as relações complexas entre religiões dominantes e o mundo encantado. Temos agora um indivíduo autônomo chamado a agir no mundo e transformá-lo; não mais um indivíduo

\footnotetext{
${ }^{17}$ De acordo com Francisco Cambi (1999), com o desenvolvimento do Humanismo na Europa já no século XV começa a se questionar o tipo de educação proposto pela Igreja, mas é apenas no século XVII que os sistemas educacionais europeus começam a ser laicizados e se tornar efetivamente responsabilidade do Estado. Philppe Àries (2012) fala também da atuação dos clérigos na educação durante a Idade Média e da posterior disputa.
} 
"preso" a uma ordem fundada no cosmo e que se explica apenas por essa vertente de pensamento.

O ponto destacado por Angela Paiva (2010) é justamente a criação da ideia de um indivíduo com direitos inalienáveis que foi possibilitada pelo processo de secularização. Ao mesmo tempo, o olhar para a religião não deixa de ser importante nas Ciências Sociais, uma vez que dependendo de qual processo for, ela irá influir na atuação do indivíduo na esfera social. Inevitavelmente, a secularização implicou numa mudança interna e externa da vida religiosa, dirá esta autora. A sua preocupação será de que maneira a religião influi na ação no mundo ou fora dele.

Para Ricardo Mariano (2011), a secularização recobre múltiplos níveis ou dimensões e está referida a diferentes fenômenos sociais e culturais e instituições jurídicas e políticas, onde se percebe uma redução da presença e influência das organizações religiosas (idem, p. 244). Este autor traz a crítica de José Casanova, que, diferente de Charles Taylor e se aproximando de Weber, vê como o mais plausível sentido para a secularização o da diferenciação das funções das esferas seculares e religiosas. Algo que pode motivar a instituição de "religiões públicas" (ibidem), nos termos do autor espanhol, religiões que buscam atuar no espaço público. Com isso, o processo de secularização não implica necessariamente no escanteio da religião à esfera privada. Paula Montero (2013) também cita Casanova e acrescenta que essa configuração fragiliza o paradigma da secularização tal como conhecemos.

A autora brasileira, no entanto, diferencia o conceito de secularização da doutrina do secularismo. Em meio às intensas disputas entre as esferas religiosa e política, tais quais Weber havia observado, "o secularismo se desenvolve como doutrina que defende uma nítida separação entre religião e política" (idem), não implica necessariamente na separação entre instituições religiosas e instituições governamentais (Montero, 2011). Demandas religiosas podem se apresentar na agenda pública, e religiosos podem ser chamados a participar da construção de políticas públicas. Citando Talal Asad, ela reforça a constatação de que quando as religiões se integram à política moderna, interessam-se em participar das discussões e das tomadas de decisão em relação aos rumos da economia, da ciência e da educação (Asad, 2003, p. 182 apud Montero, 2011, p. 4). 
Logo, segundo Montero, o secularismo evolui do campo da política para o campo da sociologia e da ética e está intimamente ligado à formação dos Estados-nação (Asad 2003 apud Montero, 2013). Com tal distinção, ela quer frisar a importância de não perceber o processo europeu de diferenciação das esferas como único modelo para que uma sociedade possa ser considerada secular ou moderna. A própria Europa, ela acrescenta, foi obrigada a repensar a até então cristalizada doutrina do secularismo por conta da emergência dos movimentos islâmicos em seu território. Em suma, segundo Paula Montero (2016, p. 147), a secularização pode ser entendida como o processo social e histórico de diferenciação das esferas e privatização da religião; o secular é aquilo que se opõe no domínio da vida social ao religioso, é o pertencente ao mundo; e secularismos seriam as diferentes teorias dos variados processos de secularização nas sociedades e na maneira como se concebem as diferenças do que é tido como mundano e do que é entendido como religioso.

\section{2}

\section{Laico, Laicização, Laicidades}

Philippe Portier (2011) define laicidade a partir de um processo histórico trazendo à tona as especificidades de cada caso. Nessa acepção, o termo é uma tradução jurídica da separação entre Estado e religião, em que o primeiro é respeitado a partir de sua soberania, e as liberdades de consciência e de culto do segundo também são asseguradas. Porém, na Europa, para onde volta a sua atenção, a laicidade em geral tornou-se parte do ethos. Este autor aproxima a ideia de laicidade a questão dos valores (Portier, 2015). Isso, porque se dá como um projeto de emancipação no plano coletivo ao afirmar a soberania da política e no plano individual ao promover a liberdade de consciência.

Laicidade representa uma clivagem entre dois modos de vida muito distintos e de duas relações de poder também diferentes: $1^{\circ}$ ) ser humano como criatura de Deus, o princípio do poder político estava na transcendência e a Igreja possuía um status abrangente; $2^{\circ}$ ) autonomia do indivíduo, o poder está a serviço das pessoas e de seus direitos, a religião como algo que cada um está livre para escolher, com isso, a Igreja se torna apenas uma instituição setorial. 
Está em jogo uma nova relação entre Estado e Igreja. Nos casos analisados por Portier, a divisão ocorre de duas maneiras. A primeira, chamada de regimes de confessionalidade, ligada aos países não católicos, onde se manteve um modelo de religião de Estado nacional (às vezes duas). Já que elas, principalmente as da vertente protestante ou ortodoxa ${ }^{18}$, representaram muitas vezes o símbolo da identidade coletiva destes países e não se constituíram como obstáculos à emancipação do Estado, relegando-se à função espiritual a partir de uma "teologia da secularidade", como Portier chama. A religião oficial recebe algumas responsabilidades e possui imunidades particulares. As outras religiões possuem o direito de existir, mas não se beneficiam do mesmo "reconhecimento" que a principal. Na prática, isso tem a ver com o recebimento de impostos e financiamentos, bem como ter mais influência, por exemplo, no sistema educacional ${ }^{19}$.

A segunda maneira de se relacionar, característica dos países de tradição católica, são os chamados regimes de separação, importante para a entrada na Modernidade por alguns países. Uma vez que, até pelo menos o Concílio Vaticano II $^{20}$, a Igreja de Roma reivindicava poder influenciar nas definições de assuntos temporais a partir de um direito divino natural. Muitas vezes, tal religião acabou por representar ainda os motivos de cisões nacionais e não de sua união como na situação anterior. Se, no primeiro caso, há intervenção do Estado na organização religiosa, aqui elas são autônomas e em princípio todas as religiões são iguais - possuem as mesmas prerrogativas e imunidades, o que na realidade pouco se verifica quando analisamos o poder de influência da Igreja Católica em detrimento de outras religiões em vários países.

Portier subdivide esse modelo em outros dois: "separação flexível”, que é o caso dos países do Norte e da parte central da Europa ${ }^{21}$, em que há uma cooperação entre Igrejas e Estado, sem admitir a ideia de uma religião oficial, mas o que implica, de

\footnotetext{
${ }^{18}$ Ex: Finlândia, Dinamarca, Bulgária, Romênia, Grécia.

${ }^{19}$ No Reino Unido, de maioria protestante, na Grécia em que há colaboração com a Igreja Ortodoxa e na Finlândia de tradição luterana, por exemplo, o ensino religioso é uma matéria obrigatória.

${ }^{20}$ Guiado pela ideia do aggiormento, o Concílio Vaticano II, iniciado em 1962, foi a definição para a entrada da Igreja Católica na Modernidade, atualizando-a e a tornando harmônica a ela. Reconheceu-se, dentre outras coisas, a liberdade religiosa, o ecumenismo e a tolerância com os não cristãos.

${ }^{21}$ Alemanha, Áustria, Bélgica, Países Baixos.
} 
fato, para as religiões principais uma dimensão pública; e "separação rígida", que ocorre essencialmente na França, em que não há de forma alguma o reconhecimento das religiões que não seja no âmbito privado. Ari Pedro Oro e Claude Petrognani (2015) em um texto sobre Baubérot, outro francês, estudioso dos processos de laicização, trazem o argumento desse autor que essa essencialização da França como a exceção das exceções na laicidade não se sustenta tanto assim. $\mathrm{O}$ processo de separação entre Igreja e Estado no México foi anterior, 1861 e com um endurecimento em 1864, tendo sido este país utilizado como referência para a separação na França, o que não significa que foi aplicada por lá.

Voltando à França, a separação rígida fica muito clara quando se percebe a relação entre escola pública e religião, exemplo paradigmático para esse trabalho, uma vez que o modelo de educação escolar brasileiro é construído em interlocução com o modelo de escola republicana francês. Desde o século XIX, as escolas públicas primárias possuem um dia livre durante a semana, as quartas-feiras. Originalmente para que caso se queira, os pais possam buscar uma educação religiosa fora do ambiente escolar (Domingos, 2008) ${ }^{22}$. Condorcet foi o primeiro a explicitar uma concepção laica de educação. É Jule Ferry em 1879 quem coloca a escola laica em funcionamento ao propor uma moral laica, independente das igrejas (idem, p. 156). Para Durkheim (2012), a preocupação da educação está em constituir o "ser social" de cada um, o que nos torna capazes de viver em sociedade, possuir um substrato que é comum a todos. Por isso, na sua visão, torna-se papel da sociedade e dever do Estado também participar do processo educacional. Dessa forma, são afastados os particularismos como o da família e a dimensão republicana do direito é trazida enquanto uma linguagem que trata os indivíduos igualmente.

Philippe Portier observa também que alguns países têm experimentado nos últimos tempos um processo de desconfessionalização e caminham para uma separação flexível que reconhece publicamente as religiões ${ }^{23}$ em sua pluralidade e com maior

\footnotetext{
${ }^{22}$ Marília de Franceschi Neto Domingos afirma ainda que "Nesse dia, as escolas abrem como centro de recreação, para receber as crianças cujos pais não desejam que os filhos frequentem o ensino religioso, ou cujas práticas religiosas não compreendem uma formação específica, ou ainda aqueles que recebem a instrução em outros dias da semana (escola dominical, dentre outras). Já para as escolas privadas, o ensino religioso é facultativo" (idem, p. 161 e 162).

${ }^{23}$ Itália, Espanha, Suécia, Grécia. Nos dos primeiros países, por exemplo, o ensino religioso é uma disciplina optativa.
} 
respeito aos não-crentes. Tal mudança veio "de cima", principalmente a partir da ideia de "diferencialismo igualitário" resguardada no Conselho Europeu, o que consiste no pensamento de que todas as crenças devem ter o igual direito de se afirmarem e de se expressarem; e que respeita os modos nacionais de regulação das crenças, mas reconhece o direito à publicidade de suas identidades culturais e religiosas privadas. Além disso, veio "de baixo", acrescenta o autor, a partir da constatação de que estas sociedades mudaram, não são mais religiosamente homogêneas. Há cada vez mais mulçumanos ou descrentes, ou então crentes de outras formas que não a dominante.

No caso da França, Portier percebe um processo, como ele nomeia, de reassociação. Antes, a separação aparece em momentos como o da instituição na III República da religião como pertencente à esfera privada e, de forma alguma, poderia entrar no espaço público, ou na legislação de 2004 que proibia o uso de signos religiosos na escola pública. Agora, a mistura aparece, por exemplo, desde a lei Debrè de 1959, que regulamenta o financiamento das escolas privadas confessionais por meio de contrato, principalmente as católicas, também as judaicas e algumas mulçumanas mais recentemente. No entanto, ocorre também na França um processo dialético. Ari Pedro Oro e Claude Petrognani comentam que, para Baubérot, já a própria a lei de 1905 não foi pensada para regular a atuação e domínio do Estado no espaço público e relegar a religião ao mundo privado, ao contrário do que se poderia inicialmente pensar.

Nessa perspectiva, a proposta era a de garantir a construção de uma sociedade civil em que pessoas diferentes e com diferentes crenças pudessem conviver de forma pacífica. Tinha a ver, então, com a possibilidade de criação de um espaço comum. Tal lei permitiu inclusive que algumas religiões minoritárias, como a islâmica, ganhassem visibilidade, como no exemplo já citado de financiamento de escolas particulares. O conselho de Estado em 2011, visando balancear duas prerrogativas da lei de 1905, a saber, a proibição do Estado em financiar cultos e a que assegura a liberdade em praticar qualquer um, propôs a construção de salas polivalentes, uma que também serviria ao culto mulçumano. Como também o estabelecimento de subsídios públicos interpretando que há ali uma separação entre o cultual e o cultural, o primeiro ligado a esfera do particular e o segundo ao bem comum. 
Nesse processo de reassociação, as instituições religiosas participam cada vez mais das redes de ação pública e dos fóruns de decisão. Portier vê com bons olhos essa "abertura progressiva da consciência francesa a um entendimento mais 'diferencialista' da existência" (Portier, 2011, p. 22). A antiga ideia republicana de uma definição pela razão abstrata, deixando de lado as afiliações de base se modificou, em grande medida, para um reconhecimento da identidade que pode sim estar ligada a uma memória e a um enraizamento anterior passível de ser considerado. O Estado, diz ele, deixou de ser visto como o "instituidor do social" para se tornar o "escriba da opinião".

Os dois movimentos, o da desconfissionalização e o do da ressociação, falam de um novo sistema europeu de regulação da crença, segundo o autor. Pautado no princípio da igualdade de tratamentos dos diferentes cultos pelo Estado, o princípio da positividade, isto é, do reconhecimento de que as religiões podem se beneficiar simbólica e financeiramente do apoio da instituição política, o que representa uma passagem de uma laicidade de "neutralidade" para uma de "benevolência". E, por último, o princípio da razoabilidade, a instituição de algumas condições para a presença das religiões no espaço público, principalmente em relação ao respeito aos direitos humanos.

Philippe Portier, em outro texto (2015), reconhece a complexidade do processo de mudança na percepção sobre a laicidade na sociedade francesa e na sua nãolinearidade. Nessa oportunidade, o autor fala de duas correntes que se polarizam: a primeira, "inclusivista" que entende que os laços sociais devem ser construídos com a ajuda do Estado e que reconhece e afirma as particularidades culturais e religiosas; a segunda, "exclusivista", ou neorrepublicana, mais poderosa socialmente, diz ele, que remete o poder da "identidade laica" para a unidade da nação em detrimento da união universal dos direitos humanos. Isso se traduz num compartilhamento de direito comum para as religiões protestantes, judaica e católica e um viés de suspeita destinado ao islamismo. O primeiro caso se cola a um nacionalismo resgatado por essa nova situação. Na prática, tal recrudescimento se traduz, diz Portier, numa "nova laicidade", pautada em uma maior regulação e repressão do Estado em relação ao indivíduo religioso. As leis de proibição do uso de signos religiosos de 2004 na escola, e de 2010 em espaços públicos são exemplos dessa nova laicidade. 
Ela visa à interdição das diferenças e tem forte apelo xenofóbico ao estigmatizar os mulçumanos e passa a regular a vida privada, como nos exemplos.

Baubérot, por sua vez, afirma que o controle do Estado se dá em relação a certas práticas religiosas e que tais medidas ferem os princípios da laicidade defendida pela lei Debré, a "laicidade histórica", como ele coloca. Este autor acredita, no entanto, na concepção dialética da laicidade (Baubérot, 2011). E se afasta de um neorrepublicanismo que põe a cargo da laicidade a imposição em relação aos religiosos que se secularizem internamente. Como também de um neoclericanismo que prega menos laicidade como forma de responder aos desafios da secularização. É por aí que vamos vendo, falaremos sempre e cada vez mais em laicidades no plural, já que advém de processos complexos e com conjunturas especificas.

Laicidade entendida como a separação entre Estado e religião tem como fundamento, para Baubérot, a partir do texto de Oro e Petrognani, possibilitar um espaço de convivência entre diferentes crenças. Com isso, diz ele, laicidade tem muito a ver com a ideia de liberdade e liberdade igual para todos que se traduz não só numa "liberdade de religião, também a liberdade da religião (Baubérot,2011, p. 59 apud Oro e Petrognani, 2015, p. 54). O religioso não se subordinou ao político no espaço público, observam os autores, com base em Baubérot.

Ricardo Mariano (2011) restringe o conceito de laicidade "à regulação política, jurídica e institucional das relações entre religião e política, Igreja e Estado em contextos pluralistas" (Mariano, 2011, p. 244). Este autor fala em emancipação do Estado e do ensino público dos ditames religiosos, em neutralidade confessional das suas instituições, em autonomia dos poderes políticos, em neutralidade em relação às religiões ou o tratamento igualitário a todas elas, em tolerância e liberdades de consciência, de religião (ter a que quiser ou mesmo não ter alguma) e de culto.

Paula Montero (2013) foca o seu entendimento sobre laicidade tendo em vista um modelo de regime político em que a ordem institucional é resultante do poder soberano dos seus cidadãos. A autora traz Jacqueline Lagrée (2010, apud Montero, 2013), que remonta a laicidade ao princípio do artificialismo do contrato voluntário quando dá a autoridade política a determinado grupo. Além disso, remonta ao 
princípio da heterogeneidade que delibera sobre a neutralidade do Estado e do reconhecimento do pluralismo de opiniões e atitudes individuais. O desenvolvimento da ascese evangélica, diz Montero, caminha para uma política de emancipação do humano, colocando Deus como transcendente e abrindo passagem para que o próprio indivíduo possa conceber por si mesmo a sua relação com o mundo. Isso em parte explica os dois regimes de que Portier falava, o confessional e o separatista.

\section{3}

\section{Secularização sociocultural e laicidade sociopolítica}

Fala-se em diferentes Modernidades, por consequência, em diferentes processos de secularização e de distintas construções da laicidade. Do mesmo modo, se tais conceitos se interconectam intensamente, inclusive, dependendo do contexto sociolinguístico, podendo ser utilizados como sinônimos, ou se intercambiar, aqui se defende uma sutil separação, mas que ilumina aspectos cruciais para a análise pretendida nesse trabalho.

A secularização implica nos processos de racionalização, autonomização e diferenciação das esferas religiosas e seculares. Por fim, tem a ver com uma mudança de visão de mundo, com um novo comportamento, um novo modo de vida possível entre tantos outros que se apresentam como opção. Não significa que não possa haver disputas e concorrências entre uma esfera e outra, ou mesmo que haja afinidades eletivas, nos termos de Weber. Quando falamos em secularização, estamos nos reportando às relações dos indivíduos, das culturas e das sociedades com a religião. Uma sociedade secularizada é aquela em que a influência das religiões diminuiu enormemente podendo até ter efetivamente acabado, o que não necessariamente se traduz em declínio das religiões.

Já a laicidade se circunscreve às diferentes formas de relação entre poderes, entre Estado e Igrejas. Por isso, tem a ver com a emergência do pluralismo religioso, com a soberania popular e liberdade de consciência, de culto e de religião, com a emancipação do Estado e do indivíduo. Logo, é também um valor, além de ser um dispositivo jurídico, a ser defendido e cultivado por uma sociedade. Um Estado é laico quando se separa do domínio eclesiástico no sentido das suas funções e regula a sua relação com as religiões existentes em determinado contexto. 
Bauderot (2011) afirma que se olharmos para a "tribo dos sociólogos da religião" perceberemos que, há meio século, se fala do conceito de secularização como pouco operatório, porque é multidimensional, mas não significa que não deixem de usálo. Às vezes, o termo é tido como um paradigma teórico, outras como conceito, para evidenciar mudanças na representação do mundo ou como um processo de diferenciação sociopolítico e institucional. Para o autor, trata-se de um conceito "ideal-típico". Como Paula Montero e Banclarte, Bauderot remonta à origem da ideia de "secular" ao diferenciar na vida monástica da Idade Média o momento que um religioso passava a viver no "Século". Mais à frente, no entanto, passou a significar a tomada de direção pelo Estado a partir de uma potência laica de aspectos e funções que antes pertenciam à Igreja. Daí suas acepções: sociocultural, diz ele, sociopolítica e sociojurídica.

Segundo Bauderot, normalmente privilegia-se a perspectiva do termo "laicização", mas como subcategoria para secularização. Ele, no entanto, radicaliza:

portanto, é o momento de praticar o agnosticismo metodológico, de dessacralizar o emprego do termo "secularização"! De um ponto de vista heurístico, é mais operatório empregar dois conceitos diferentes (Bauderot, 2011, p 287).

Assim, para Bauderot, a secularização daria conta das mudanças socioculturais por causa da evolução dos saberes e técnicas, e pelo desenvolvimento da racionalidade instrumental, o que se traduz em mudanças nas representações societais do mundo e nas atuações na vida pública. O processo de laicização, por sua vez, se deteria à regulação política, jurídica e institucional da religião, do credo, dos seus simbolismos e os conflitos inerentes a tal relação.

Paula Montero (2013) se aproxima do autor francês ao colocar a ideia de secularismo no nível societário e a sua doutrina política a partir da emancipação do religioso e a ideia de laicidade se colar ao regime jurídico do Estado. Possui também uma visão mais dialética entre Modernidade e religião ao não afirmar de antemão uma "antinomia radical entre mundo laico e mundo religioso" (Montero, 2013, p.15), fundamental para este trabalho.

Ricardo Mariano (2011) reconhece as críticas de Bauderot em relação ao conceito de secularização, mas chama a atenção, a partir também de Micheline Milot (2009, p. 11 apud Mariano, 2011, p. 245), que a própria ideia de laicidade pode ser 
pluridimensional - política, jurídica, cultural e social - que se inscreve nas construções das nações democráticas. Ele relembra que na literatura sociológica inglesa secularism, Secular State e secularist têm geralmente o sentido próximo da laicização institucional (do Estado e do ensino público), de Estado laico e laicista ${ }^{24}$. Conclui:

De todo modo, cabe reconhecer, de um lado, a delimitação conceitual mais precisa ou restrita do termo laicidade. De outro, cabe observar que o conceito de secularização, quando referido especificamente ao processo de secularização do Estado, do ensino, da política, da esfera jurídica, por exemplo, nada perde em precisão em relação ao de laicidade (idem, p. 245 e 246).

Reconhecer a escola pública como um espaço pluridimensional tem a ver com o desafio de compreender tal instituição na sua complexidade. Assim, fala-se em laicidade na escola pública na medida em que se quer destacar o aspecto político disso, a sua relação enquanto instituição pública destacada do domínio religioso. Também, significa enfatizar a laicidade como um valor, tal como destacou Portier, mais ou menos defendido e cultivado e que tem o seu sentido disputado, inclusive, no "chão da escola". Trazer à tona os atores ali envolvidos - diretores, coordenadores pedagógicos, professores, alunos e famílias - como sujeitos que trazem consigo as suas identidades e crenças mais ou menos secularizadas é perceber que tal separação e/ou emancipação não está dada.

\section{4}

\section{Secularização e laicidade no Brasil}

É importante atentar para a necessidade de se ter uma visão dos interstícios entre cultura e religião; e entre formação social, política e religião. Só assim podemos entender um pouco da complexidade da formação identitária brasileira, por meio da sua construção histórica, como atesta Carlos Rodrigues Brandão (1988). Essa que passa pelo compartilhamento de determinados valores e crenças e, mais do que isso, por uma negociação e reconhecimento mútuo de determinados códigos, signos e significados.

Torna-se oportuno compreender como se deu a concepção tradicional da laicidade brasileira que acomodava um catolicismo latente, por meio da associação à

\footnotetext{
${ }^{24 “} \mathrm{O}$ laicismo é uma forma agressiva, combativa de laicidade que procura eliminar, extirpar a religião da vida social. O laicismo se mostrou na história política de diversos países ocidentais como fortemente anticlerical e antirreligioso" (Ranquetat Jr, 2008).
} 
identidade nacional acionado pelo sincretismo como um elemento integrador, o que não deixou de ser lastro e se interligar à concepção mais recente de cidadania que se pauta na percepção da sociedade como um conjunto vasto de diferenças: de crenças, de cor, de posição social, de gênero, etc. Além disso, perceber a cada vez maior presença dos evangélicos, crucial para a consolidação e o reconhecimento do pluralismo religioso. E como tem "perturbado" um arranjo - entre a Igreja católica e a política - que estava há muito tempo acomodado.

\subsection{1}

\section{Identidade e Sincretismo}

A velha relação entre Estado e Igreja veio como herança da colonização portuguesa e quase nunca deixou de existir. O catolicismo no primeiro momento da colonização foi a liga para a integração nacional. Depois, a convivência e influências dos cultos africanos, indígenas e o desenvolvimento de um catolicismo popular foi uma das molas propulsoras para a construção de um sincretismo religioso. A Igreja Católica seguiu sendo a religião oficial até mesmo após a independência, durante o Império, separando-se do Estado apenas com a proclamação da República.

A solidariedade social se deu por meio da fé religiosa, dirá Gilberto Freyre (2006), e Sérgio Buarque de Holanda (1995) concorda ao afirmar que a religiosidade se perdia e se confundia em um mundo ainda sem forma, o que fez então com que nenhuma elaboração política fosse possível fora da religião. Desse modo, Maria Isaura Pereira de Queiroz (1988) afirma que a força e a coesão das religiões funcionarão por aqui contra o perigo da desintegração e descontinuidade dos grupos sociais e Paula Montero (2013) dialoga com esta autora ao dizer que a grande influência na maioria dos aspectos da vida social e política da Igreja Católica possibilitou sua atuação para "cimentar o sentimento de unidade nacional" (Montero, 2013, p. 22). A Igreja Católica sendo unitária nesse primeiro período, colocava-se como exclusiva e tinha no seu "rebanho" os indígenas catequizados e os escravos também obrigados a se batizar, além, é claro, dos brancos. Nesse sentido, Brandão afirma que, para além de se constituir como maioria, o catolicismo "é socialmente a possibilidade de todas as categorias de sujeitos sociais possuírem uma mesma religião e diferenciarem, no seu interior, modalidades próprias de sua 
religiosidade" (Brandão, 1988, p. 47). Ou seja, era a única maneira possível de manter aspectos da cultura de origem por meio da mistura de elementos.

A influência, no entanto, era mútua e sua proximidade era muito maior com as práticas das pessoas dos diversos interiores brasileiros do que com a oficialidade episcopal ligada à Roma. Faltavam padres, as hierarquias eram de famílias, a identificação de lugares sagrados e de novos santos eram feitas por leigos, as superstições imperavam. Praticava-se um catolicismo muito mais mágico que intelectual. Isso era visto com maus olhos, pois era tido como inferior, o que se deu foi uma verdadeira criação religiosa, aponta Queiroz, a dos cultos sincréticos. De outro lado, um catolicismo popular fazia vista grossa às outras formas de religiosidade, muito em função da ideia de sincretismo religioso, um sincretismo hierárquico (Mariano, 2011 apud Freston 1993). Entretanto, o status de religião era dado apenas à denominação católica. Ao seu lado, os cultos afro-brasileiros e indígenas iam sendo colocados como "crendices", portanto ocupando um lugar menor, tal qual o Espiritismo kardecista a partir do século XIX. Como Brandão afirma, o ecumenismo era estendido até os limites do protestantismo, mas sem tirar do católico tradicional a crença de que a sua Igreja é o lugar privilegiado de fundação do Brasil.

Para Montero (2011), tais características de formação do campo religioso no país, além da quase universal crença dos brasileiros num conceito específico de Deus único e transcendente, inspirado no catolicismo, fizeram com que os requisitos para que uma denominação fosse aceita socialmente como religião viessem daí: levar em conta um processo histórico implícito, demonstrar que benefícios materiais não seriam seus primeiros objetivos e ter o ideal cristão da caridade, que se associa à secular assistência social. Só assim, dirá a autora, se reconhecerá tal religião como legítima na busca do bem comum. Nesse sentido, nas mesmas primeiras décadas do século XX em que surgia no Brasil a Umbanda, uma religião com elementos de todas as matrizes que nos compunham enquanto nação, a ordem era higienista, criminológica e cientificista, como coloca Mariano. Detinha no catolicismo o modelo de religião em contraponto às práticas "mágico-religiosas" espíritas e afrobrasileiras. Estas duas últimas vistas como patológicas e/ou ilegais. Isso só muda posteriormente, quando elas se aproximam das características inspiradas no 
catolicismo, aí começam a ser vistas como religião. Como aponta Emerson Giumbelli (2008), a noção de caridade foi fundamental para que os porta-vozes espíritas, também alvos das incursões policias e judiciárias, por conta de suas práticas terapêuticas, pudessem ter as suas práticas enquadradas à noção de religião.

Se no início, evangelização e colonização caminhavam juntos, de certa forma justificados pela "missão" civilizadora que os portugueses traziam para si e depois com a dispersão no vasto território nacional, passou-se a desenvolver um catolicismo popular/rústico e/ou de família. Já no Império, as tensões eram mais aparentes. Paula Montero (Esquivel, 2008 apud Montero, 2013) atesta que no Regime de Padroado a Igreja era subordinada à autoridade estatal monárquica em detrimento do Vaticano. Angela Paiva (2010) atenta-se que no Padroado a relação era de obrigações e deveres, não havia espaço para os direitos individuais, apenas para os direitos cristãos. As tensões levavam a intromissões do Estado nos próprios assuntos da Igreja, o que fez com que fosse criada uma "pastoral coletiva do episcopado brasileiro" que apoiava claramente o regime republicano pouco tempo antes dele ser instaurado.

Paula Montero entende esse movimento como uma das explicações para a consolidação da hegemonia histórica cristã na sociedade brasileira. Uma vez que, ao se constituir a República, influenciada pelo iluminismo europeu e seu anticlericalismo, em oposição ao catolicismo ou melhor dizendo, ele mesmo se retirando da constituição estatal, tal instituição foi para a sociedade civil, o que sem dúvida a fortaleceu. Está aí a peculiaridade do caso brasileiro, afirma a autora, a construção da identidade nacional e da ideia de laicidade, pelo menos a institucional, deu-se com influência do próprio clero católico, o que já nos afasta da classificação feita por Portier, por exemplo, uma vez que não ocorre no Brasil o "separatismo" tal como ele definiu ao observar os países de tradição católica na Europa. A disputa para a construção da laicidade brasileira teve então dois lados: o da Igreja Católica que se retirava do Estado, mas que a essa altura já detinha grande parte da constituição da identidade nacional, principalmente dos mais pobres e, por isso reivindica na primeira Constituição da República, valores cristãos e o lado positivista dos letrados e dirigentes que almejava o afastamento de tudo isso. 
Dessa maneira, se em um primeiro momento a Igreja Católica fez parte da construção estatal brasileira, no período posterior, ela se tornou autônoma, o que lhe deu mais liberdade para atuar na sociedade brasileira, agora a partir da oficialidade da Santa Sé. Angela Paiva observa que a Igreja Católica se fortaleceu muito institucionalmente nesse período, por conta das alianças de autoridades eclesiásticas e as elites, e ainda por meio da abertura de várias dioceses e escolas católicas. A laicidade no Brasil instituiu-se, como observa Montero, a partir da regulação dos direitos e deveres da Igreja Católica e não da regulação dos direitos e deveres de todas as crenças religiosas, sua atuação no espaço público e apaziguamento de conflitos não se fez dessa forma porque "a República instituiu o secularismo mais do que o pluralismo religioso" (Montero, 2011, p. 2). Ou seja, no primeiro caso não há real necessidade de se separar Igreja e Estado, os conflitos então eram tidos como inexistentes e as outras religiões não eram consideradas ou percebidas a partir desse estatuto. $\mathrm{O}$ sincretismo unificava as diferenças, afirma a autora. Ricardo Mariano (2011), reafirma que tal separação não possibilitou o fim dos privilégios da Igreja Católica e nem da discriminação estatal às outras religiões, principalmente às da vertente espírita. O caminho tomado não foi, de maneira nenhuma, o da neutralidade religiosa. A laicidade enquanto um valor, tal como destacou Portier, definitivamente não foi escolhido para ser defendido pela sociedade brasileira.

Até os anos de 1940, dirá Ricardo Mariano, reprimiam-se os ritos e práticas afrobrasileiros ao enquadrá-los como crimes de feitiçaria, curandeirismo e charlatanismo (Maggie, 1986 apud Mariano, 2011). O caminho então se seguiu por um maior registro em cartórios desses grupos enquanto religiões, o que não se traduziu necessariamente numa diminuição da perseguição dessas instituições. Em 1939, durante a Ditadura do Estado Novo, investiu-se no Departamento de Defesa da Fé, em uma política de oposição em relação aos protestantes e em favor da "nação católica" (Rolim, 1985, p. 72 apud Mariano, 2011, p. 246). Outro órgão criado em 1953, o Secretariado Nacional para a Defesa da Fé e da Moralidade, tinha objetivos parecidos com o anterior: vigiar a expansão das "falsas religiões" (Mainwaring, 1989, p. 54 apud Mariano, 2011, p. 247), freá-las e condená-las. Esse esforço exposto e direto se deu, segundo o autor, até fins da década de 1950. 
$\mathrm{O}$ catolicismo até a primeira metade do século $\mathrm{XX}$ no Brasil se beneficia e beneficiará o tipo de formação social brasileira, ligada a uma sociedade patriarcal, hierarquizada e rural. Desse modo, é de se esperar que a sua atuação se torne um anteparo para que a laicidade não se desenvolvesse enquanto um valor a ser defendido pela sociedade, o que sem dúvida contribuirá para o processo de modernização conservadora que se dará nesse período. Como veremos no capítulo seguinte, o momento imediatamente anterior a esse é crucial para o acirramento das disputas no campo educacional brasileiro e remetem a projetos educacionais opostos, como também de sociedade.

\section{4 .2}

\section{Cidadania e Pluralismo religioso}

O reconhecimento do pluralismo religioso e da competição religiosa só ocorrerá, segundo Mariano, com a redemocratização em 1988, por conta do crescimento acelerado do pentecostalismo e seu ingresso na televisão e na política partidária, o que não significa que tal processo já não estivesse em curso anteriormente. Porém, nesse momento, a perspectiva passa a ser outra, a adesão religiosa efetivamente torna-se uma questão de opção pessoal e consciente, o que contribui para a legitimação do chamado mercado religioso no Brasil.

De acordo com Mariano, ocorreu uma mudança fundamental com esse novo cenário, uma vez que o pentecostalismo chama para si uma identidade que é exclusiva. Ele foi crucial para a consolidação do pluralismo religioso; para a maior defesa da liberdade religiosa e de culto; e para que enfim houvesse uma ruptura com a lógica de monopólio no campo religioso, ao colocar em xeque a já tradicional vinculação entre catolicismo e nacionalidade. Logo, o sincretismo é posto em suspenso. No pluralismo há várias opções em disputa em um mercado. Estabelecese com isso, dirá Mariano, a "modernidade religiosa no Brasil" (Mariano, 2011, p. 248).

De outro lado, houve a facilitação por parte da Igreja Católica a partir da década de 1960 com o Concílio Vaticano II, que reconheceu o direito à liberdade religiosa, além do surgimento da Teologia da Libertação e das Comunidades Eclesiais de Base (CEBs) e da "opção preferencial pelos pobres", o que levou a um maior engajamento, nesse período, na luta contra a Ditadura Militar que se endurecia, 
como também na atuação direta em movimentos sociais. Em contrapartida à guinada progressista, a reação católica contra o avanço do pentecostalismo, na visão de Mariano, que relembra a fala do Papa João Paulo II em visita ao Brasil, para a necessidade de "impedir o avanço de seitas no Brasil" (Mariano, 2011, p. 249), se deu pela expansão do movimento carismático, inclusive com investimento em redes de televisão. A resposta ao avanço pentecostal, segundo o autor, se deu na migração para as esferas midiática e política. Mesmo vedando a participação do clero, o Vaticano incentiva a participação de leigos na política partidária. Além disso, atua por meio da influência da Confederação Nacional dos Bispos (CNBB), da pressão direta de lideranças em relação aos políticos, da realização de parcerias com os poderes públicos, da insistência dos seus valores religiosos e de suas bandeiras políticas nas diversas redes que possuem. Para daí influenciar na formatação de políticas públicas e na constituição de leis principalmente quando se trata da moral familiar e sexual, aborto, uso de métodos contraceptivos, educação religiosa em escolas públicas, união civil homossexual e eutanásia (Duarte, 2009 apud Mariano, 2011, p. 249).

Mariano aponta ainda que durante a Ditadura Militar ganhou-se cada vez mais espaço entre os evangélicos dirigentes de uma ala mais conservadora, salvo exceção da Igreja Evangélica de Confissão Luterana do Brasil (IECLB). As denominações pentecostais, por sua vez, passaram a atuar politicamente a partir da Constituinte de 1987. Antes disso, vigoravam duas perspectivas: "o dever de votar no governo e, salvo raras exceções, não se envolver com política" (Mariano, 2011, p. 250). A virada dos pentecostais e de algumas denominações evangélicas na Constituinte se deu por medo de que a Igreja Católica expandisse seus privilégios com a escrita da nova Constituição (idem; Vital da Cunha e Lopes, 2012). A antiga autoexclusão se traduziu em uma atuação política e midiática que visavam a defender os seus valores morais, a família e os bons costumes em detrimento dos católicos, dos homossexuais, dos "macumbeiros" e das feministas. Esta era uma maneira de tornalos visíveis, de divulgá-los. Assim eles definitivamente entraram na disputa da arena política no final dos anos de 1980. Christina Vital da Cunha e Paulo Vitor Leite Lopes apontam que não foram só os pentecostais que pensaram assim, a Igreja Batista também entrou na discussão da Constituinte para defender o Estado laico, alegando que nenhuma religião deveria ter espaço privilegiado na relação com o 
Estado. Ao longo do tempo, as denominações evangélicas foram aumentando as alianças com partidos laicos e as suas próprias candidaturas.

Para Ricardo Mariano, tal imbricação entre religião e política no Brasil tem representado um empecilho à laicização da esfera pública brasileira. Embora seja importante frisar, existe um acordo no Brasil quanto à laicidade do Estado: ele deve estar separado da religião (Giumbelli, 2012 apud Montero, 2013), o que não se traduz em outro consenso sobre a doutrina do secularismo a ser adotada e se deve haver adesão a ela.

Mariano percebe, por outro ângulo, que cada vez mais o que está em jogo são as disputas sobre o sentido da laicidade, inclusive sobre qual tipo de interpretação que se fará sobre a laicidade definida pela Constituição. Grupos diferentes partem de "saberes, bases axiológicas, interesses, posições sociais e institucionais distintas, e frequentemente antagônicos”. (Mariano, 2011, p. 252). Isso não é nada trivial e está longe de ser resolvido. Grupos laicos aproximam seu sentido ao modelo de tradição republicana francesa, que defende a laicidade no ensino público, a forte separação entre Estado e igrejas e a diminuição da participação de lideranças religiosas na esfera pública. Já grupos religiosos, afirma Mariano, tendem a defender uma laicidade que reconheça a sua participação na esfera pública e no seu espaço, mas que mantenha consonância com uma laicidade jurídico-política do Estado, que respeite essa prerrogativa. Todos os grupos, no entanto, afirmam respeitar e defender a laicidade, reafirmando, é claro, a sua interpretação, os seus valores e interesses. O papel do Estado na definição deste conceito também é de fundamental importância, de acordo com o autor, pois é a partir daí que se dita, afinal, que tipo de laicidade será adotada e que tipo de atuação das religiões será tolerada.

Para Mariano, a laicidade no Brasil não possui força normativa e nem histórico de atuação que levem a uma maior secularização da sociedade, o que tem indicado uma redefinição da fronteira entre o público e o privado, uma reordenação da relação entre religião e política, e uma desprivatização ou publicização do religioso a partir da admissão da ação religiosa nos espaços públicos (Burity, 2001; 2006 apud Mariano, 2011). A separação entre Igreja e Estado na instituição da República, entretanto, nunca resultou em privatização da religião, como também na exclusão entre religião e política. Além disso, não desencadeou um movimento anticlerical 
radical como foi em outros lugares. Mesmo tendo aparecido como importante naquele momento, a laicidade não se constituiu como valor central da República, digna de ser defendida e buscada de qualquer forma, nem teve na sua retaguarda uma sociedade tão secularizada. Ainda, vincular catolicismo e poder público, acrescenta Paula Montero, não é percebido pela sociedade brasileira como ameaça à laicidade. Na contemporaneidade, o sentido de bem coletivo ainda está associado a uma ética cristã, ou, ulteriormente, ligada aos seus valores. Em suma, juridicamente a laicidade é assegurada desde o início da República, na realidade, pela ótica dos atores envolvidos, aponta a autora, não se adere ao secularismo. Nas suas palavras,

Desse modo, poderíamos afirmar que a doutrina do secularismo à moda brasileira vai em direção da expansão da religiosidade no espaço público, seja no sentido da disputa para conferir a todas as religiões os mesmos privilégios já constitucionalmente garantidos à Igreja Católica, seja transformando cada vez mais variadas religiões em índice de nacionalidade. Não se pode deixar de notar que essas foram exatamente as duas modalidades por meio das quais a Igreja Católica garantiu historicamente suas pretensões de influir no ordenamento da vida social (Montero, 2013, p. 26).

É como se então as outras religiões, a começar pelas evangélicas, principalmente as pentecostais, tivessem "aprendido os passos" com a Igreja Católica e buscassem, guardadas as devidas diferenças de contexto e de atuação, repeti-los e aprimorá-los. Simultaneamente, é à laicidade que se remetem quando se trata de debates e conflitos que envolvam grupos laicos e religiosos (Mariano, 2011, p. 254). Mariano pega emprestado o termo que Fernando Catroga utiliza para falar dos países católicos do sul da Europa, Portugal, Espanha e Itália, e o utiliza no Brasil ao dizer que há, em grande medida, uma "quase laicidade" (Catroga, 2006 apud Mariano, 2011). A nossa diferença em relação a esses países é o aumento recente da disputa entre católicos e pentecostais.

Está em curso uma mudança na maneira pela qual os brasileiros se percebem enquanto sociedade. $\mathrm{O}$ problema da identidade nacional lastreado na identidade católica tradicional com o seu sincretismo hierárquico, de certo modo, pautava uma cidadania que se dizia inclusiva, embora na prática tratasse desigualmente pessoas de determinadas religiões, situação social, cor etc. Tendo como marco a Constituição de 1988, o paradigma do sincretismo, visto como integrador das diversidades étnicas e culturais dá lugar à ideia de inclusão que distingue a 
sociedade como um conjunto de diferenças, inclusive de crenças. Conjuntamente, a mudança no campo religioso brasileiro irrompe, por meio dos evangélicos, especialmente dos pentecostais, e exige, por meio desse grupo religioso, uma cidadania que se quer exclusiva.

\section{5 \\ Imbricações do uso dos conceitos e premissas}

Peter Berger (2000) é um dos estudiosos das religiões que volta um pouco atrás ao falar do conceito de secularização. Ele salienta que é falsa a afirmação de que vivemos num mundo secularizado, uma vez que não se verificou o declínio da religião, apesar dos efeitos secularizantes da Modernidade que, afinal, aparecem em mais lugares que em outros. Faz isso se apoiando na hipótese de que o mundo em que vivemos é tão ou mais religioso do que era antes e traz dois movimentos de reavivamentos religiosos para comprovar a sua tese: o islamismo e o evangelismo. O primeiro caso, mesmo com fortes diferenças internas, caracteriza-se por uma restauração não só das crenças, também do modo de vida islâmico, muitas vezes, que vai de encontro a algumas ideias modernas. Esse é um movimento que também se verifica em países com alto grau de modernização. O segundo caso, em conversões no extremo Oriente e principalmente na América Latina. Cecília Mariz (2000) chama atenção que no segundo caso não houve o processo de secularização nos termos ocorridos em outros lugares, como a Europa, por exemplo. Com isso, não haveria de ter ocorrido uma dessecularização por aqui. Os pentecostais se expandem entre grupos sociais que possuem uma visão de mundo nada secular, logo, não haveria aí um reavivamento.

A exceção à sua tese de dessecularização é a Europa, mas mesmo lá, segundo Berger, o que mais se observa é uma mudança no lugar institucional da religião. $\mathrm{O}$ autor nesse momento se aproxima da definição de Charles Taylor sobre secularização, como vimos no início. Outra exceção é a elite secular formada por pessoas com ensino superior no modelo ocidental, principalmente pertencentes às Humanidades e às Ciências Sociais, que, apesar de pouco numerosas, têm ampla influência na definição do que é a "realidade", o que se contrapõe aos surtos religiosos, geralmente populares. 
Podemos tirar daí duas proposições que dialogam com o caso brasileiro. A primeira é que a secularização não implica necessariamente num declínio do religioso. Como vimos acima, a separação entre Estado e Igreja, isto é, a laicidade, não teve como retaguarda uma sociedade secularizada que tivesse nesse valor jurídico-político o seu bastião. Além disso, nos ajuda a entender a complexidade deste processo e as mútuas influências entre política, cultura e sociedade, já que, por muito tempo, como pudemos ver, o catolicismo se vinculou fortemente no Brasil à identidade nacional. Foi fundamental para a mudança dessa perspectiva a explicitação de um mercado religioso, ou seja, a evidenciação do pluralismo. Deu-se então largada à disputa.

O segundo aspecto trazido por Berger que devemos ter atenção é o das exceções à dessecularização. Por muito tempo, as análises nas Ciências Sociais feitas com base numa ideia da Europa como modelo perdeu em muito no sentido de perceber as peculiaridades de cada processo. No caso do Brasil, é como se estivéssemos sempre "em atraso", como se ainda fôssemos viver o que por lá já ocorre. Hoje, com a perspectiva das múltiplas Modernidades, podemos afirmar que nem todos os lugares passarão pelo que a Europa passou, e mesmo lá não se teve processos tão homogêneos, um declínio tão amplo em relação à religiosidade. Este não é o caso dos Estados Unidos, por exemplo, uma sociedade fortemente secular, mas muito religiosa, e também não é o caso do Brasil. Uma configuração como a nossa, que manteve estreitos laços entre Estado e Igreja Católica mesmo após a separação oficial das duas instituições, certamente passou por outros caminhos. A ressalva que se faz a isso é que sem dúvida, apesar das diferenças, existem certamente pontos de contato, principalmente num mundo que se globaliza e de certo modo experimenta alguma homogeneização, o que necessariamente implica então na relevância de uma análise construída por meio da interlocução.

É interessante notar o fato de como os autores europeus ao falarem das novas questões por conta da imigração, principalmente de mulçumanos no seu território, como também a partir da crítica pós-colonial, podemos iluminar a diversidade religiosa brasileira, falando especificamente do tema que nos é caro aqui. É claro que não vivemos, ou que há pouca ressonância (mas já há alguma), com a questão mulçumana no Brasil. Essa nova atenção pode nos ajudar a esclarecer o pluralismo 
religioso, deixando de lado uma perspectiva anterior conciliatória que tinha no sincretismo hierárquico o seu epítome no que tange à religiosidade e solapava as diferenças, para destacar o conflito. Uma sociedade que deixa de se perceber na unidade e passa a se conceber na diversidade.

Berger chama a atenção para a elite secular que olha os movimentos religiosos populares com desconfiança. É importante ter isso em mente quando se tem à frente tal cenário. Há muita dificuldade em perceber o campo religioso quando apenas se vincula o declínio da religião como diretamente proporcional a uma maior intelectualização. Weber já havia feito essa ressalva quando fala do processo de racionalização das religiões mundiais por meio da criação de uma elite que administrará os "dons da graça". Estar atento a isso de antemão não é algo corriqueiro. Só assim perceberemos as suas dobras.

É nesse sentido que absorvo a premissa de Patrícia Birman (2003) ao chamar atenção para que não aceitemos de antemão que exista uma separação clara entre o mundo laico e religioso, mas que percebamos os seus entrelaçamentos e confrontos e as configurações que podem vir daí, ao reconhecer as religiões enquanto atores sociais. Muitas vezes, pensar como banal a religião como pertencente ao "foro íntimo" ou mesmo apenas a sua própria esfera, diz ela, não nos permite ver certas configurações do que se define como religião que acontecem no complexo espaço público nas sociedades contemporâneas. A sua crítica é de que as Ciências Sociais geralmente "carregam" nesse quesito e, dessa maneira:

Concedem menos atenção às dinâmicas que ultrapassam os limites normativos fixados pelo Ocidente cristão e moderno (felizmente, jamais inteiramente obedecidos) nas sociedades que se dizem laicas e seculares (Birman, 2003, p. 12).

A sua perspectiva é a de que o "religioso" e a "sociedade" se constroem mutuamente. De certo modo, Paula Montero dialoga com esta autora ao tratar da abordagem pioneira do uso teórico-metodológico marcadamente mais weberiana dos trabalhos brasileiros inaugurados por Antônio Flávio Pierucci (1986;1989;1990 apud Montero, 2013) sobre a presença crescentes de religiosos no Congresso Nacional, o que, na sua visão, contribuiu para que tal problematização fosse vista a partir de um viés da "invasão" da esfera política pelos agentes religiosos (Montero, 2013, p. 20) sem levar em conta os limites do paradigma da secularização Montero se questiona se em algum momento da história brasileira as religiões deixaram de 
ocupar os mais variados espaços da vida social. Para ela é complicada a ideia de dizer que elas estão "fora de seu lugar".

Por isso, o foco da análise vai para a própria construção do secularismo que se fez nesse trabalho ao analisar a relação entre religião e política. Um conceito que não pode ser limitado apenas à ideia de um regime que supõe a separação do poder burocrático em face do eclesiástico, o que se tem são múltiplas relações e, por isso, de acordo com Paula Montero, o foco não deve ser o normativo. Existem diferentes intepretações e uma disputa de significados, principalmente quando se percebe que a antes naturalizada percepção católica como nacional e como construção do "bem coletivo" já é criticada; e também quando a própria justificativa construída por religiões ao disputar as agendas públicas se torna secular, como nos exemplos trazidos pela autora ao se falar em assistência pública, educação, cultura e ciência abandona o domínio da fé.

Ao analisar de que forma o pentecostalismo influi no comportamento do campo religioso brasileiro, Cecília Mariz e Roberta Campos (2014) criticam a dificuldade de grande parte dos sociólogos e antropólogos brasileiros que estudam religião em perceber as mudanças trazidas pelo vertiginoso aumento dos adeptos das religiões dessa vertente do protestantismo no Brasil. Isso porque, na visão das autoras, tais estudos apontariam sempre as continuidades. Assim, o aumento dos pentecostais é justificado pela ideia de que estas religiões se adaptaram à cultura brasileira e não o contrário. Há um risco aí de se incorrer na essencialização do conceito de cultura.

As autoras priorizam, porém, uma análise relacional, que também perceba as rupturas e consiga dar conta do processo de mudança pelo qual a sociedade brasileira vive. Esse que pode ser interpretado como sendo uma reforma moral está mudando o mito da brasilidade representado não só pelo decrescimento do catolicismo, também das próprias religiões afro-brasileiras. Com a presença cada vez maior dos evangélicos e também dos sem religião podem surgir novas demandas, uma delas é o questionamento da laicidade brasileira de uma forma completamente diferente do que se fazia até então, enquanto um valor a ser disputado. 


\section{3 \\ Católicos, protestantes, pentecostais e a história educação brasileira}

A professora coloca um santinho católico no mural no fundo da sala de aula, passa um inspetor, ela tira, quando ele sai, a professora o recoloca. Essa é uma cena do filme cubano Numa escola de Havana (Conducta originalmente), de 2014, dirigido por Ernesto Daranas. Guardadas as devidas peculiaridades de contexto histórico, político e social, tal cena poderia ser utilizada como metáfora para a relação sempre presente entre religiosidade, escola e a construção social da laicidade nesse ambiente, não só em Cuba, também no Brasil.

A instituição escolar como um dos mais importantes espaços de afirmação da separação entre Estado e Igreja é tão implícita que chega a ser curiosa a informação trazida por Roberto Blancarte (2011, p. 185): a primeira vez que se tem notícia da utilização do termo "laicidade" (laïcité em francês) data de 1871, quando houve uma votação no Conselho Geral da Região do Sena (la Seine) na França sobre o ensino laico como sendo uma educação não confessional e sem instrução religiosa. A partir daí, nesse país, a educação laica se constituiu, como coloca o autor, na "coluna vertebral" da luta por instituições sem a influência das religiões tal como se imagina nas sociedades republicanas.

Neste capítulo, continuaremos nos aprofundando no estudo do processo de secularização e construção da laicidade estatal brasileira, dando ênfase agora à história social e cultural da escola pública pelo viés da sua relação com o catolicismo em dois momentos cruciais: uma breve incursão ao Brasil Colônia e Imperial para destacar a relação dos jesuítas com a educação escolar; e um foco mais aprofundado no período republicano, principalmente para situar as disputas entre os reformadores ligados à Escola Nova e o grupo católico. A partir daí o capítulo também destacará a história dos protestantismos e pentecostalismos no Brasil e as mudanças advindas do crescimento das igrejas evangélicas. 


\section{1 Colônia e Império: Jesuítas e o monopólio da educação escolar no Brasil}

Durante o século XVI, a Igreja Católica colocou-se contra o movimento de ampliação da instrução iniciado pela Reforma Protestante na Europa e fez tudo o que pôde para que ele não crescesse. Depois, no entanto, resolveu combater a Reforma com os seus próprios princípios. Sua Contrarreforma trazia para si a prerrogativa sobre a instrução, os livros e as escolas. A França, por exemplo, fiel ao Concílio de Trento, que definiu tal mudança, realizou durante os séculos XVII e XVIII "uma verdadeira ideologia da escola, concebida ao mesmo tempo como inseparável da educação cristã” (Marcílio, 2005, p. 10). Escolas essas pensadas para os pobres da cidade que influenciarão fortemente o mundo moderno ocidental.

É aí que começa a grande tarefa dos Jesuítas, uma vez que suas escolas para leigos foram as mais bem-sucedidas. $\mathrm{O}$ ensino nesse período não se distinguia do catecismo: "instrução" ou "doutrina" englobava a instrução religiosa, moral e leitura, escrita e contagem (Lebrun, F. p 243 apud Marcílio, 2005, p. 6). A Companhia de Jesus tinha como principal missão a evangelização da fé católica. E, como herdeiros do humanismo renascentista, definiram o seu Ratio Studiorum ${ }^{25}$ que regulava o sistema escolástico. Portugal ficou isolado da revolução científica e filosófica que ocorria no resto da Europa nesse período. Assim, mantiveram-se contra o conteúdo crítico e a favor das formas dogmáticas de pensamento e da reafirmação da autoridade da Igreja ou mesmo dos antigos, além dos exercícios intelectuais que fortaleciam a memória e capacitavam o raciocínio para comentar textos.

Simbolicamente, pode-se dizer que o primeiro ato educacional feito em terras brasileiras foi o desembarque de seis missionários jesuítas em 1549 junto com Tomé de Souza, nosso primeiro Governador Geral (Miranda, 1966). A Igreja foi, desde o princípio da história brasileira, a primeira e, por muito tempo, até meados do século XVIII, a única instituição educacional no Brasil, como também havia sido em Portugal até então. Logo, não é à toa a sua legitimidade adquirida nesse assunto (Lima, 1978; Marcílio, 2005). Priorizaram a educação secundária para os jovens

\footnotetext{
${ }^{25}$ Programa de estudos.
} 
brancos, meninos, filhos da elite colonial. Educação essa focada no estudo clássicohumanista que preparava para o Ensino Superior. A outra vertente educacional era destinada às crianças indígenas. E consistia no ensino das primeiras letras e no catecismo. A primeira foi ganhando cada vez mais importância, na medida em que seus alunos iam se tornando os mais novos representantes da Colônia junto à Corte. Além disso, fundaram colégios, internatos para a formação de futuros padres, também provenientes da elite. Poucas escolas aceitavam os filhos de colonos, apenas os que eram órfãos ou abandonados. Ainda, embora de forma desigual, uma pequena parte da população negra ia sendo educada também, graças a inciativas particulares, de associações ou irmandades (Barros, 2016).

Em suma, sob a tríplice proteção da Coroa, da Igreja e da família patriarcal, os jesuítas puderam constituir uma das mais poderosas influências na formação da sociedade brasileira. Aliado a isso, pode-se dizer que o lugar privilegiado que ocupavam no governo português e que afastava qualquer outra iniciativa, mesmo eclesiástica e o profundo preparo intelectual da Companhia, além de sua grande habilidade política, possibilitaram a consolidação de sua obra educacional e do seu monopólio nesse quesito (Chagas, Valnir, 1978, apud Marcílio, 2005). Nota-se, como aponta Otaíza de Oliveira Romanelli (2009), que o arranjo da família patriarcal escravocrata com os seus hábitos aristocráticos de vida, beneficiou-se em muito do monopólio dos jesuítas na educação; uma vez que separava quem era destinado a acessar o sistema educacional e quem não deveria nem chegar perto dele.

Foi Marquês de Pombal quem introduziu a escola pública na Colônia, que só se deu com a expulsão dos jesuítas em 1759 e foi regulamentada apenas em 1772. O vácuo de 13 anos foi preenchido por preceptores particulares para os meninos mais ricos e para o resto, a quase totalidade, garantia-se o ensino das atividades paternas e dos elementos de instrução cristã ensinados pela mãe. As reformas na instrução pública foram inspiradas no iluminismo português, de base reformista, nacionalista e humanista, mas não tão radical como o francês, por exemplo. Mexeu-se na instrução primária e secundária, com aulas de ler, escrever e contar, junto com a doutrina cristã por via de aulas-régias fragmentadas e sem continuidade, com "mestresrégios", geralmente despreparados e ignorantes, mas pela primeira vez: leigos. 
Embora os professores mais recrutados ainda fizessem parte do clero secular, o que persistiu mais à frente, durante o Império. Em matéria de regularização do ensino, pouco se fez com a chegada da Família Real em 1808: mantinham-se as aulas avulsas no secundário e as aulas de ler, escrever e contar no primário. E o domínio da Igreja ainda era garantido por lei.

No Brasil, o clima efervescente das ideias liberais e positivistas levou à Independência que teve a sua primeira Constituição em 1824. Ela, apesar de manter a religião católica como oficial, permitia o culto doméstico às outras religiões. Proibiu-se a perseguição religiosa, apenas nos casos de ofensa ao Estado e à moral pública. Por aí eram enquadradas as religiões afro-brasileiras e também as espíritas nesse período, geralmente consideradas atentatórias à moral e aos "bons costumes" (Cunha, 2013). Adicionou-se a isso, o Código Criminal do Império, de 1830, que reforçava tal criminalização, na medida em que se consideravam quaisquer dos costumes dos escravos negros e de seus descendentes como possibilidade de insubordinação e perigo de revolta, como observa Nathália Fernandes de Oliveira (2015).

No século XIX, importou-se o método inglês de Ensino Mútuo ou monitorial ${ }^{26}$. É a primeira vez que se fala em instrução para meninas: "se instruída ela será uma boa esposa e como mãe seria capaz de criar de forma cristã seus filhos" (Marcílio, 2005, p. 63). A Constituição de 1824, em uma lei complementar, como aponta Surya Pombo de Barros (2016), proibia a entrada de negros ${ }^{27}$ nas escolas nesse período, o que foi reforçado por leis estaduais posteriormente.

Mais uma vez se garantia o ensino dos "princípios da moral cristã e da doutrina da religião católica e apostólica romana, proporcionados à compreensão dos meninos" (Cunha, 2013, p. 32). Isto é, garantia-se o Ensino Religioso e o catecismo como obrigatórios e a situação de crise do clero secular contribuiu para que, pelo menos nesse período, a Igreja Católica aceitasse sem tanta contestação a instituição pela primeira vez do ensino público (Marcílio, 2005, p. 45). Mesmo assim, as famílias ricas mantinham preceptores para os seus filhos, que eram geralmente sacerdotes

\footnotetext{
${ }^{26}$ Alguns adolescentes instruídos diretamente pelo mestre ensinavam aos outros alunos.

${ }^{27}$ Leia-se: escravos, libertos, filhos de africanos livres, não livres, pretos e ingênuos (Barros, 2016, p. 593).
} 
seculares. A educação da imensa maioria dos mais pobres era apenas uma transmissão oral por meio de um catecismo de perguntas e respostas decoradas, bem como orações e doutrinas.

Ao mesmo tempo, a demanda por educação só aumentava com o surgimento de uma pequena camada intermediária urbana que, desde sua formação, percebia o valor da escola enquanto possível forma de ascensão social (Romanelli, 2009, p. 37). O Ato Adicional de 1834 deu direito às províncias de legislar sobre a instrução pública primária e média. Iniciava-se um longo debate que se arrastou séculos à frente: a centralização ou descentralização do ensino. O secundário continuou a ser apenas uma preparação para o superior, o que se fez apenas foi uma tentativa de reunir as aulas régias em liceus, mas a maior parte dele era particular. Quase nada se investiu no ensino primário. O Decreto Couto Ferraz de 1854 que regulamentava o ensino primário e secundário proibia a matrícula e a frequência de escravos nas escolas de ensino primário e secundário (Barros, 2016). No ano seguinte a 1878, outra reforma tornou o ensino primário obrigatório para meninas e meninos entre 7 e 14 anos, com multas previstas para os pais que não cumprissem. Em resumo, mantinha-se a lógica do ensino primário para o povo e o secundário reservado para as elites.

O monopólio da Igreja Católica no período entre a Colônia e o Império levou a uma multiplicidade de formas possíveis de se ter a experiência com o catolicismo no Brasil (Brandão, 1988). Isto é, uma pessoa poderia se engajar de maneira mais intensa, a partir da participação em irmandades e congregações e constituir o clero, por exemplo, até apenas ter uma relação com essa instituição religiosa de forma mais oficial ou mesmo apenas como um costume (Machado, 1996). Para os efeitos deste trabalho, importa notar que grande parte do aprendizado em relação ao catolicismo nesse período, suas doutrinas, valores, ritos e interpretações de mundo, enfim, a cultura católica, se dava no ambiente escolar.

\section{2}

\section{República: disputas entre católicos e Pioneiros}

O início da República foi marcado por uma grande aposta na educação. É nesse período que se formam as bases do pensamento escolanovista, e começa a sua influência: é pela educação que será possível incorporar as grandes camadas da 
população e levá-las junto com o país para a linha do progresso, é também por ela que se formará o "novo homem brasileiro" (Marcílio, 2005, p. 132). Entretanto, antes disso, tal crença se dá primeiramente por conta da influência positivista que chega ao Brasil a partir da segunda metade do século XIX. Passado o primeiro momento mais marcado pela defesa da separação do Estado e da Igreja, pouco a pouco, foi-se retomando a influência da Igreja Católica, vista como portadora de “forças morais" imprescindíveis à tarefa de reconstrução nacional (Cury, 1978).

As escolas Politécnicas e de Direito, além dos clubes republicanos, foram os principais irradiadores do positivismo no Brasil ainda em fins do Império e influenciaram fortemente o processo de proclamação da República. Um dos seus pontos mais marcantes era a defesa da laicidade do Estado. Assumiu grande importância também no campo educacional, como veremos, por meio de diferentes reformas que, em grande medida, se constituíam como uma reação à obra educacional da Companhia de Jesus. Adicionando-se aos republicanos, os abolicionistas também, na passagem do Império para a República, colocavam-se como mais que laicos, anticlericais, dada a omissão da Igreja Católica em relação à escravidão que, ao contrário, acabava por incentivá-la (Paiva, 2010).

Em 1890 determina-se a plena e total liberdade de culto, é suprimida as restrições até então vigentes aos não católicos e proibida todos os níveis do Poder Público de estabelecer alguma religião (Cunha, 2013). O Regime de Padroado foi extinto. A partir da primeira Constituição Republicana, de 1891, em que é explicitada a separação do Estado em relação à Igreja Católica, todas as religiões passaram a poder ter cultos públicos ${ }^{28}$. No entanto, as religiões afro-brasileiras e espíritas continuaram sendo criminalizadas pelo Código Penal de 1890, tidas como charlatanismo, junto ao samba, enquadrado como vadiagem, e a capoeira.

Quanto ao ensino, a Constituição era clara: "Será leigo o ensino ministrado nos estabelecimentos públicos" (Cunha, 2013). Luiz Antônio Cunha atenta-se para a sua marca positivista:

essa foi a única passagem de uma Constituição brasileira, até os dias atuais, em que uma atividade do Estado brasileiro foi explicitamente qualificada na legislação de laica. Em todas as demais, a laicidade é implícita, e tem de ser deduzida, devido às

\footnotetext{
${ }^{28} \mathrm{Além}$ disso, os registros de nascimentos e casamentos tornaram-se responsabilidade do Estado e os cemitérios foram secularizados.
} 
ambiguidades remanescentes no ordenamento jurídico do nosso país (Cunha, 2013, p. 44).

A educação teve a sua primeira Reforma com Benjamin Constant, um positivista heterodoxo que tratou de laicizar o ensino público, tornou o currículo enciclopédico, introduzindo disciplinas científicas. O ideário positivista foi fiador da ação intervencionista do Estado, inclusive em matéria de educação. Foi muito intensa nesse momento a valorização no discurso de um Ensino Fundamental livre, gratuito e leigo (Marcílio, 2005). Em alguns períodos dos primeiros 30 anos republicanos, introduziu-se a disciplina Moral, de feição também positivista (Cunha, 2009).

Concomitantemente, a Igreja Católica passou nesse período por uma profunda reestruturação institucional vinculada à Santa Sé, o processo de "romanização", como ficou conhecido (Dallabrida, 2005). Houve um crescimento do número de dioceses Brasil afora. Embora tenha concordado com a separação do Estado em relação à Igreja, a laicidade do ensino foi vista como uma agressão à fé católica da maioria do povo brasileiro. Apesar de defender a separação entre Estado e Igreja (Lima, 1978, p. 75), D. Sebastião Leme ${ }^{29}$ foi o autor da tese do "caráter nacional" do catolicismo no povo, reivindica o retorno do Ensino Religioso e a necessidade de reconhecimento, pelo Estado, do catolicismo enquanto "religião da maioria" e, portanto, o Brasil como uma nação católica. Propôs então a formação de uma elite capaz de influir politicamente e levar as ideias católicas a público (Cury, 1978). Dessa forma, a saída encontrada foi a consolidação de uma rede de escolas católicas (Dallabrida; 2005; Paiva, 2010).

\footnotetext{
${ }^{29}$ Foi arcebispo de Olinda e Recife entre 1916, e 1921 e arcebispo do Rio de Janeiro entre 1930 e 1942. Grande incentivador do desenvolvimento da instrução religiosa da elite e Defensor do Ensino religioso facultativo e das escolas superiores católicas. Em 1922 apoiou a criação do Centro D. Vital, fundou a Confederação Católica do Rio de Janeiro. Em 1932, fundou o Instituto Católico de Estudos Superiores (ICES). Organizou e assumiu a direção da Liga Eleitoral Católica (LEC). Em suas viagens ao Vaticano, insistiu na criação de uma universidade católica no Brasil. Em fins de outubro de 1940, foi assinado o decreto federal que autorizava a abertura das faculdades de Direito e Filosofia, cujos cursos foram instalados oficialmente em março do ano seguinte e se tornaram o embrião da Pontifícia Universidade Católica do Rio de Janeiro (PUC-Rio), pouco tempo depois. Disponível em: http://www.fgv.br/cpdoc/acervo/dicionarios/verbete-biografico/sebastiaoleme-de-silveira-cintra.
} 
O decreto Concili Plenari Americae Latinae, do Concílio Vaticano $\mathrm{I}^{30}$ fala explicitamente da educação primária, secundária e universitária em um dos seus pontos sobre a "educação católica da juventude". E tem como um dos “impedimentos e perigos da fé", as "escolas acatólicas e neutras" (Wernet, 1991a apud Dallabrida, 2005, p. 78). Esse era um reforço para a justificação do investimento em escolas católicas. Mais à frente ainda, em 1915, o documento conhecido por "pastoral coletiva", resultado de várias conferências episcopais, condena as escolas laicas e determina que os católicos frequentem apenas escolas que tenham Ensino Religioso na sua grade curricular (Pastoral Colletiva, 1915; Oliveira, 1985 apud Dallabrida, 2005, p. 78).

Aquilo que não era ensino católico seria necessariamente considerado ensino ateu na visão da Igreja no período (Azzi, 2008, p. 154). Assim, passaram a atuar em todo o território nacional ordens e congregações católicas masculinas e femininas de origem europeia ${ }^{31}$ que chegam ao Brasil nesse momento e introduzem práticas católicas romanizadas. Tal entrada intensificou-se ainda mais após a promulgação da Constituição de 1891. Essa que garantiu algumas liberdades para a Igreja Católica retraindo o anticlericalismo radical do momento da proclamação da República (Dallabrida, 2005). Tais congregações acreditavam ser "enviados com o dever de ensinar a verdadeira doutrina cristã, contribuindo para reconstruir o colonialismo cultural europeu" (Dallabrida, 2005). A maioria delas então atuou na "reconversão" dos brasileiros à fé católica romanizada em detrimento do catolicismo popular, por meio das redes de instituições assistenciais e educativas, como orfanatos, creches, casas de saúde, hospitais, asilos e principalmente colégios e escolas que criaram. Como atesta Angela Paiva (2010), não houve registro de nenhuma escola religiosa fundada especificamente para a promoção da educação dos negros.

A Constituição de 1891 previu a descentralização do ensino. Eliminou-se a seleção pela renda, manteve a seleção pela instrução, favorecendo assim os setores médios

\footnotetext{
${ }^{30}$ Realizado entre 1869 e 1870 e proclamado pelo papa Pio IX, definiu uma constituição dogmática sobre a fé católica e sobre o primado e a infalibilidade do Papa em assuntos de fé e moral.

${ }^{31}$ Além dos jesuítas que se permitiu pela Constituição que ficassem, outras congregações também foram incentivadas a vir para o Brasil e tiveram liberdade de ação (Wernet, 1991b; Cury, 2001 apud Dallabrida, 2005). Algumas delas: lazaritas, salesianos, maristas, franciscanos, lassalistas, irmãs de São José de Chamberry, Apóstolas do Sagrado Coração de Jesus e Irmãs da Divina Providência.
} 
e excluindo os analfabetos. A partir daí muitas foram as reformas, mas foram tentativas frustradas ou então pontuais em meio aos mais variados comandos políticos (Romanelli, 2009). Em 1911, os positivistas mais extremos passaram a defender veementemente a liberdade de ensino e a uniformização do secundário. Assim, foi aprovada uma reforma que tornava o ensino oficial autônomo, os cursos secundários não seriam mais equiparáveis, instituía-se o exame de entrada para o ensino superior. O secundário depois passou a ser seriado. Em contrapartida, com a permissão de entrada para as congregações religiosas, a partir da década de 1920, a Igreja Católica passou a investir fortemente na educação. A escola protestante e o ensino leigo eram tidos como os principais adversários da Igreja Católica nesse período (Azzi, 2008). Com esse projeto acreditavam que formariam as elites nos princípios cristãos, o que, seguindo essa perspectiva, tornaria o Brasil um Estado católico novamente (Azzi, 2008).

O texto da Pastoral Coletiva recomendava também a fundação de escolas primárias em cada paróquia, as chamadas escolas paroquiais. Expandidas no Brasil para fazer frente às escolas públicas laicas com sua "pedagogia moderna". Foram importantes principalmente nas regiões de imigração europeia, especialmente no sul do país. O prédio escolar ficava ao lado da Igreja ou da capela ou mesmo dentro delas. E até a década de 1930, alfabetizavam os filhos dos camponeses. Quando foi retomado o Ensino Religioso nas escolas públicas, não houve mais necessidade de se investir nesse tipo de escola.

Já no ensino secundário, a predominância era de ginásios católicos ${ }^{32}$. A expansão da rede pública de ensino secundário se dará mais à frente, apenas durante a Ditadura do Estado Novo. As escolas de ensino secundário das ordens e congregações católicas, direcionadas para as elites, dividiam-se geralmente em internatos: o colégio de padres para os meninos e o colégio de freiras, que ofereciam o Normal, para as meninas. Uma vez que não havia mais os auxílios financeiros do Estado, como era no período imperial, os colégios começaram a ser utilizados como uma fonte de recurso eficiente e lucrativa. Possuíam docentes com formação europeia, quase inexistentes nesse período no Brasil, e almejados pela elite

\footnotetext{
${ }^{32} \mathrm{Em}$ 1931, por exemplo, mais de três quartos das 700 escolas secundárias existentes no Brasil eram católicas (Brueneau, 1974, 9. 122 apud Dallabrida, 2005, p. 81).
} 
(Dallabrida, 2005). A difusão das escolas públicas, todavia, representava uma diminuição do público das escolas católicas, principalmente o de menor poder aquisitivo e nas pequenas cidades, onde também tais escolas eram numerosas (Azzi, 2008).

A "recatolização" da intelectualidade nos moldes romanos se deu não só pelas instituições escolares, como também a partir da liderança de D. Sebastião Leme, pela imprensa, confederações religiosas e formas de engajamento. Dessa maneira, criou-se a revista mensal A Ordem na década de 1920 e o Centro D. Vital, um instituto que reunia intelectuais católicos militantes, tais como o próprio D. Leme, Jackson de Figueiredo ${ }^{33}$, Alceu Amoroso Lima ${ }^{34}$, Padre Leonel Franca ${ }^{35}$, Hamilton Nogueira $^{36}$, Sobral Pinto ${ }^{37}$. Além disso, o forte apelo para a criação de faculdades católicas $^{38}$. Por último, mas não menos importante, bispos e padres com a ajuda fundamental das congregações e do laicato católico, incentivaram os católicos que fossem professores a fazerem o Normal e prestarem concursos públicos para

\footnotetext{
${ }^{33}$ Foi quem fundou o Centro D. Vital. Morreu precocemente em um acidente.

${ }^{34}$ Recém convertido, foi um dos principais líderes do laicato católico. Ocupou o cargo de diretor do Centro D. Vital e editor da revista A Ordem, a partir de 1928 quando Jackson Figueiredo morreu precocemente. Assumiu a orientação política conservadora. Assumiu em 1929 a direção da Coligação Católica Brasileira, criada com o objetivo de congregar todas as associações católicas no país. Foi encarregado de planejar, juntamente com outros líderes católicos a Liga Eleitoral Católica (LEC). Combateu o Manifesto dos Pioneiros da Educação Nova. Participou da criação e assumiu a direção nacional da Ação Católica Brasileira (ACB) em 1935. Começou a rever seus princípios filosóficos e políticos a partir da década de 1940, continuando católico, mas retornando às suas concepções liberais. Tornou-se forte crítico da Ditadura Militar. Escreveu para diversos jornais. Disponível em: http://www.fgv.br/cpdoc/acervo/dicionarios/verbete-biografico/lima-alceuamoroso

${ }^{35}$ Foi membro do Conselho Nacional de Educação em 1931 e vice-reitor do Colégio Santo Inácio no Rio de Janeiro. Foi um dos fundadores da Pontifícia Universidade Católica do Rio de Janeiro e seu primeiro reitor.

${ }^{36}$ Ajudou a fundar e tornou-se vice-presidente do Centro D. Vital. Foi deputado constituinte em 1946; senador pelo Distrito Federal em 1946; deputado federal pelo Distrito Federal em 1959 e pela Guanabara em 1960. Disponível em: http://www.fgv.br/cpdoc/acervo/dicionarios/verbetebiografico/hamilton-de-lacerda-nogueira

${ }^{37}$ Advogado. Escreveu para A Ordem. D. Leme passou a pressioná-lo, pois havia escrito artigos de crítica ao Governo Provisório de Vargas. Ainda em 1933, Sobral Pinto aderiu à Liga Eleitoral Católica (LEC). Em 1936, foi encarregado pela seção carioca da Ordem dos Advogados do Brasil de defender Luís Carlos Prestes e Harry Berger. Foi um crítico assíduo da Ditadura Militar, atuando publicamente em diferentes ocasiões. Disponível em: http://www.fgv.br/cpdoc/acervo/dicionarios/verbete-biografico/heraclito-fontoura-sobral-pinto ${ }^{38}$ Criou-se o Instituto Católico de Estudos Superiores (ICES) em 1932. Em 1940, são fundadas as "faculdades católicas". As faculdades de Direito e Filosofia começaram a funcionar no ano seguinte e tiveram como reitor o Padre Leonel Franca. Em 1946, elas foram congregadas com a Escola de Serviço Social e se transformaram na Universidade Católica do Rio de Janeiro, que se tornou pontifícia no ano seguinte (Dallabrida, 2005, p. 83).
} 
também contribuir para a "recatolização" da cultura escolar republicana e laica (Dallabrida, 2005, p. 79).

Insta lembrar ainda que, como coloca Ricardo Mariano (2011), a discriminação às religiões afro-brasileiras, como também ao Espiritismo kardecista ainda eram muito presentes na vida social brasileira nas primeiras décadas do século XX. Embora, estivéssemos em tempos de República, o modelo do que se considerava religião, como pudemos ver, ainda era o católico; e as práticas "mágico-religiosas" espiritas e afro-brasileiras eram interpretadas sob à luz das correntes higienistas, criminológicas e cientificistas tão comuns à época. Elas só irão ser descriminalizadas na medida em que se aproximam das ideias de caridade e assistência tão caras às tradições cristãs e católica (Giumbelli, 1997; Montero, 2006 apud Mariano, 2011).

\subsection{1}

\section{As disputas entre os Pioneiros da Escola Nova e os católicos em torno da escola pública}

A Revolução de 1930 é o grande marco para a virada da política educacional brasileira. Apesar do grupo vencedor não ter trazido consigo um programa educacional definido e integrado, eles se fizeram valer da grande efervescência ideológica do período. Os debates daqui para frente, até logo antes da Ditadura de 1964, são basicamente divididos entre: os defensores da Escola Nova, portanto da laicidade do ensino, da coeducação ${ }^{39}$ e da escola pública; versus os conservadores, sendo a Igreja Católica a maior fiadora daquilo que entendiam como "liberdade de ensino", e os defensores da escola particular ${ }^{40}$. Para isso, tal instituição revia o papel do Estado em assumir a função educadora, criticava fortemente a laicidade do ensino e reagia à campanha em favor da escola pública que se agigantava cada vez mais. Como aponta Otaíza Romanelli, a legislação foi sendo criada de forma contraditória, ora balanceando as correntes em oposição, ora agradando uma em detrimento da outra. O saldo, entretanto, na sua visão, pendeu para o lado da

\footnotetext{
${ }^{39}$ Ensino misto numa mesma unidade escolar, ou seja, de ambos os gêneros de forma conjunta.

${ }^{40}$ Embora uma minoria de intelectuais católicos, como Mario Casassanta, Jônatas Serrano, Everardo Backheuser e Heitor Lyra, tenha aderido ao movimento pela Escola Nova, a reação católica oficial foi radicalmente contrária (Azzi, 2008, p. 306). Além deles, o então padre Helder Câmara, que criticou severamente a pedagogia catequética tradicional e desenvolveu uma metodologia de ensino do catecismo na Escola Nova (Lima, 1978).
} 
corrente conservadora, representado principalmente pelos católicos. Ainda, a Igreja tornou-se aliada do Estado na luta anticomunista. Iniciava-se a disputa, uma das mais profícuas do campo educacional brasileiro até hoje.

Este também é o período de industrialização e urbanização brasileira, com o surgimento de setores urbanos, o enfraquecimento da família patriarcal de origem rural e a crescente entrada da mulher no mercado de trabalho. Fatores que, junto com o início do uso dos anticoncepcionais mais à frente, na década de 1950, levaram a uma mudança enorme nos hábitos e costumes das pessoas, especialmente das mulheres. Como aponta Riolando Azzi (2008), a Igreja reagiu insistindo nos padrões tradicionais de sexualidade e de família. O projeto institucional de "recatolização" da sociedade brasileira de que falava anteriormente, teve como forte alavanca não só o investimento em escolas católicas e em intelectuais, como também, e principalmente, a "promoção da vida familiar".

Tendo-se como modelo a Sagrada Família: Jesus, Maria e José, em 1939 foi criada a Liga de Defesa da Família que, entre outras coisas alertava contra a educação física e a educação sexual ${ }^{41}$. A Igreja constituiu-se inclusive em um grande entrave até a década de 1960 para que se avançassem as discussões sobre educação sexual no sistema escolar brasileiro, de acordo com Elisangela de Araújo Guimarães Carvalho (2016). Defendia-se, no limite, a defesa da ordem social, isto é, manutenção do status quo, contra as inovações liberais ou socialistas. Nessa visão, a tradicional ética familiar e sexual funcionaria como empecilhos às mudanças socioculturais que estavam por vir. Nesse período, era clara a orientação católica em evitar qualquer alteração importante da ordem social vigente no Brasil (Azzi, 2008).

Outro ponto interessante que teve reverberação nos sistemas educacionais brasileiros e se intensificou nesse período, principalmente durante a Era Vargas, foi a colaboração entre religiosos e militares para a educação dos jovens, com vistas ao civismo e ao patriotismo. Os educadores católicos buscaram incutir em seus alunos o respeito e a admiração pelos militares, sendo ajudados por eles principalmente na

\footnotetext{
${ }^{41}$ Indissolubilidade do matrimônio, família numerosa, mulher enclausurada no lar, submissão dos filhos, saudosismo do passado e denúncia do mundo moderno, solução sobrenatural para os problemas sociais (Azzi, 2008, p. 146).
} 
educação física e militar e nas orientações cívicas e patrióticas. Valores como ordem e disciplina eram exaltados. Buscava-se por meio aprovação, a obtenção de recursos econômicos para as escolas católicas (Azzi, 2008). Como salienta Cunha (2009), a disciplina Moral ou Educação Moral e Cívica foi suprimida durante a Ditadura do Estado Novo apenas quando o Brasil lutou com os Aliados durante a Segunda Guerra Mundial, o que retirou o seu suporte político-ideológico naquele período.

Voltando à cronologia, já em 1931, foi criado o Conselho Nacional de Educação (CNE) por iniciativa de Francisco Campos, Ministro do governo provisório, como um órgão consultivo do ministro. Alceu Amoroso Lima e o padre Leonel Franca são figuras importantes do grupo católico que tiveram assento no Conselho, o que sem dúvida contribuiu nesse momento para um certo equilíbrio de forças nas diretrizes educacionais (Azzi, 2008). Em 1932, Campos continuou no cargo, no recém-criado Ministério da Educação e Saúde. Reformou o ensino superior, secundário e comercial. Deixou de lado o ensino primário e normal, além de outros tipos de ensino médio profissionais. Era a primeira vez, entretanto, que uma reforma atingia a estrutura de ensino em todo o território nacional ${ }^{42}$. Adiante, no mesmo ano, assumiu no lugar de Campos, Whashington Pires, para o desagrado dos católicos, embora sua entrada não tenha de fato significado um rompimento radical com a perspectiva do anterior (Cury, 1978).

Antes do retorno do Ensino Religioso nacionalmente em $1931^{43}$ como um dos primeiros decretos de Getúlio Vargas, pelo menos seis estados voltaram a adotar tal disciplina de forma facultativa, fora do horário normal das aulas (Dallabrida, 2005; Cunha, 2013). Em Minas Gerais, por exemplo, no final da década de 1920, era

\footnotetext{
${ }^{42}$ Antes disso, as Reformas se limitavam ao Distrito Federal que deveria servir de "modelo" aos outros estados.

${ }^{43}$ Texto de Amoroso Lima saudando o decreto: "o Governo provisório acaba de dar o primeiro passo no caminho da única revolução que pode salvar a nacionalidade brasileira: a revolução espiritual" (...) "Há quarenta anos que vivíamos em um equívoco permanente. Há quarenta anos que os poderes públicos forçavam a consciência de numerosos alunos das escolas públicas oficiais, privando-os do ensino religioso exigido pela sua fé. Há quarenta anos que os direitos dos pais sobre a educação religiosa dos seus filhos eram sistematicamente violados pelo laicismo em vigor. Há quarenta anos que gerações e gerações de brasileiros passavam pelos estabelecimentos de educação primária, secundária, normal e superior sem que uma só palavra lhes indicasse o sentido profundo de tudo aquilo que estudavam." (...) "Só a aliança do Estado com a Igreja Católica e com a família podem dar a nossa instrução pública a base da realidade nacional, de universalidade cultural e de espiritualidade cristã que o laicismo desastroso the roubou." (Lima, 1978, p. 76).
} 
autorizado o Ensino Religioso nas escolas estaduais primárias, secundárias e normais e os procedimentos eram tais que apenas o catolicismo acabava podendo ser ensinado. Para aprovação do decreto federal, Campos elaborou a distinção entre educação e instrução: se o objetivo da escola era o de educar, então, na visão do Ministro, era preciso que se levasse em conta a dimensão ético-religiosa da vida, respeitando a vontade das famílias dos alunos (Cury, 1978, p. 109).

Um dos principais problemas brasileiros desse período era o educacional: no início do século XX, quase $80 \%$ da população brasileira era analfabeta (Bomeny, 2003). A maioria morava no campo, mas nem mesmo estar na cidade era garantia de acesso à educação primária (Romanelli, 2009). Embora tal realidade fosse escancarada, a primeira vez que de fato o debate sobre a educação ganhou ares de debate público foi a partir da década de 1920. Um dos seus palcos principais foi a Associação Brasileira de Educação (ABE), fundada nesse período. Tal entidade liderava um movimento que tinha como objetivo sensibilizar o poder público em relação aos principais problemas da educação brasileira e chamar atenção para a urgente necessidade de resolvê-los (Romanelli, 2009). A partir deles, surgiu um grupo de educadores influenciados por um novo ideário sobre a escola, vista dos ângulos da Filosofia, Psicologia e da Sociologia e por vários autores que se reuniam sob a égide da chamada "Escola Nova".

Durante a IV Conferência Nacional de Educação veio a motivação desse grupo em precisar e publicizar suas ideias em um Manifesto. Assim foi, em 1932, publicado o "Manifesto dos Pioneiros da Educação Nova", que, dentre outras coisas, defendia a gratuidade, obrigatoriedade, a laicidade e a coeducação para o ensino público brasileiro. Isto é, a defesa do direito de todos à educação e a responsabilidade do Estado em ofertá-la (Romanelli, 2009). A divisão entre católicos e escolanovistas se deu primeiramente nas Conferencias da ABE. A Conferência citada tinha como objetivo elaborar diretrizes para uma política nacional de educação, objetivo este que não foi cumprido dado o grau da polêmica que se instaurou em torno da laicidade do ensino e da disputa dos dois grupos. A discussão se aprofundou ainda na V Conferência e foi objeto de diversas publicações em jornais. O Manifesto para os católicos era um "documento socialista e comunizante” (Cury, 1978, p. 23). 
O clero católico era habituado a manter os seus interesses relacionados aos da elite rural e atravessado por uma visão de mundo autoritária e hierarquizada (Azzi, 2008). Por isso, via na interferência do Estado uma possibilidade para o monopólio da educação e a laicidade uma afronta aos princípios da educação católica (Romanelli, 2009). Em grande medida, tal defesa se justifica no até então quase monopólio da educação mantido pela própria Igreja Católica. O entendimento não foi que o Estado não teria condições materiais de obter o monopólio educacional e nem mesmo que não era essa a sua intenção em momento algum (Romanelli, 2009). Além disso, se o projeto era o de "recatolizar" a sociedade brasileira para os católicos, o Ensino Religioso deveria ter lugar privilegiado nessa forma de ação. Defendiam ainda uma educação mais academicista e autoritária, o que mais uma vez os aproxima das velhas elites.

Alceu Amoroso Lima e o padre Leonel Franca conseguiram exercer influência marcante no Ministério da educação. Além deles, D. Leme atuou fortemente contra a laicização do ensino e em defesa do Ensino Religioso nas escolas públicas. A acusação de comunismo inclusive foi uma arma poderosa dos católicos durante esse período (Azzi, 2008). Para a Igreja, nesse momento histórico, a sociedade com uma educação pautada pelos princípios católicos era a única possível. Em seu livro, Ensino Religioso e Ensino Leigo, Padre Leonel Franca traz argumentos de diversas áreas para justificar o Ensino Religioso:

(...) pedagógico, afirma que só a religião pode ser regra normativa para a Educação, negando à moral cientifica capacidade para isso, daí a condenação à escola leiga; social, a escola leiga, professando em principio uma abstenção impossível, a respeito dos grandes princípios orientadores da existência, condena-se à superficialidade educativa e à impotência social; jurídico, sustenta que a escola leiga não é neutra entre vários credos, mas inclui uma posição irreligiosa ou arreligiosa. (Lima, 1978, p. 78).

Segundo Carlos Roberto Jamil Cury (1978), a Igreja percebia, nesse momento, o Ocidente enquanto um mundo em crise principalmente moral, com o "desmoronamento das instituições vigentes e da desorientação das consciências individuais" (Cury, 178, p. 27). A crise no Brasil se relacionaria à crise geral, mas teria aspectos específicos: várias revoluções, transtornos políticos e reformas educacionais que teriam sido motivadas pela "apostasia republicana do Estado e laicismo pedagógico" (Cury, 1978, p. 38). Os princípios republicanos racionalistas, positivistas e maçônicos - seriam alheios à tradição do povo brasileiro. A mudança no sentido da nacionalidade, tradicionalmente cristã e 
católica, deu-se por conta, na visão católica do período, graças a gerações que foram educadas nos primeiros anos da República, que não ouviram falar de "deveres morais e nem deveres religiosos". A elite dirigente formada nesse período foi então negadora da presença de Deus. O pouco que se ouviu foi graças à família, principalmente às mulheres e às escolas privadas que mantiveram a educação moral. Os cidadãos brasileiros teriam se tornado "filhos da desordem moderna, anarquia pedagógica, do empirismo cientifico e da incultura generalizada" (Cury, 1978, p. 39). A própria instituição católica teria contribuído para chegar em tal situação, ao permitir uma ignorância doutrinária e colocação da religião na esfera sentimental. Na concepção católica do período, a ordem social baseava-se primeiramente no espiritualismo ensinado pela filosofia e religião católicas que reeducaria o indivíduo e daí a sociedade. A moral era vista enquanto força disciplinadora que mantinha a ordem e a estabilidade (Cury, 1978, p. 42). E o Estado deve conservar um mínimo de espírito cristão.

Os Pioneiros, como ficaram conhecidos os intelectuais do movimento pela Escola Nova, também acreditam que se atravessava uma crise, mas por conta dos avanços tecnológicos, científicos e da industrialização, o que levariam a mudanças na organização do trabalho e na família e vice e versa. A escola, local privilegiado da educação, deveria então, se ajustar a tais transformações e contribuir para que se formasse uma democracia social (Cury, 1978). Daí a função do Estado em assumir a educação.

Por conta da cada vez maior complexificação do mundo, principalmente na sua ordem econômica, para os Pioneiros, a influência educativa da família começou a diminuir e a função da escola a aumentar. A perspectiva desse grupo de intelectuais trazia para o centro a figura do aluno em sua acepção psicológica e social, impondose o desenvolvimento integral de suas capacidades criadoras, pesquisadoras e investigadoras. Por isso, defendiam a substituição do método memorizador pela valorização do raciocínio lógico e pela imaginação, além da ênfase na cultura científica (Lima, 1978; Azzi, 2008). E a formação de sua personalidade moral possibilitaria o cultivo da solidariedade, da cooperação social e do espirito de justiça que, cada um, fim em si mesmo, segundo o que acreditavam os escolanovistas. 
Destaca-se no Manifesto a defesa da escola pública ${ }^{44}$ e gratuita ${ }^{45}$. Para eles, se estamos numa sociedade heterogênea, a educação pública deveria ser laica, pois só assim respeitaria a personalidade e a confissão religiosa de cada $u^{46}{ }^{46}$. Além disso, o direito de todos significaria a igualdade de direitos entre homens e mulheres na possibilidade de acesso à mesma educação ${ }^{47}$. As diferenças na ação pedagógica viriam a partir das diferenças psicológicas dos alunos, de suas aptidões e interesses pessoais, apenas.

O Manifesto de 1932 foi elaborado por Fernando de Azevedo, mais influenciado por Durkheim, então na relação entre educação escolar e República e assinado por 22 educadores, líderes do movimento, dentre eles Anísio Teixeira, esse mais influenciado por Dewey, desse modo focado na relação entre educação e Democracia, Cecília Meireles, Antônio de Almeida Júnior e Manuel Lourenço Filho e representou uma tomada de consciência por parte deles e um compromisso. Tais signatários acreditavam numa relação dialética entre educação e desenvolvimento, na necessidade de utilização do método científico para entender os problemas educacionais, na importância de uma reconstrução educacional em âmbito nacional e não a partir de reformas estaduais que seriam sempre parciais. A educação deveria se adaptar às mudanças. Era vista enquanto um direito e não um privilégio de determinada classe social, por isso deveria ser um sistema único. $\mathrm{O}$ Manifesto pedia ainda uma ação mais incisiva do Estado em prol da escola pública, mas não recusava a contribuição da iniciativa particular; autonomia para ação educativa e descentralização; aponta para a

necessidade de colocar "o ambiente escolar acima das seitas, disputas religiosas, de dogmatismo" e de excluir do mesmo "qualquer influência perturbadora à personalidade do educando", impõe-se que seja leigo o ensino, na escola pública (Romanelli, 2009, p. 147).

\footnotetext{
44“"A escola oficial, única, em que todas as crianças, de 7 a 15 anos, todas ao menos que, nessa idade, sejam confiadas pelos pais à escola pública, tenham uma educação comum, igual para todos" (Manifesto dos Pioneiros da Educação Nova, 1932 apud Lima, 1978, p. 71).

45“'A gratuidade extensiva a todas as instituições oficiais de educação é um princípio igualitário que torna a educação, em qualquer de seus graus, acessível não a uma minoria, por um privilégio econômico, mas a todos os cidadãos que tenham vontade e estejam em condições de recebe-la" (Manifesto dos Pioneiros da Educação Nova, 1932 apud Lima, 1978, p. 71).

46"A laicidade, que coloca o ambiente escolar acima de crenças e disputas religiosas, alheio a todo o dogmatismo sectário subtrai o educando, respeitando-lhe a integridade da personalidade em formação, à pressão perturbadora da escola quando utilizada como instrumento de propaganda de seitas e doutrinas" (Manifesto dos Pioneiros da Educação Nova, 1932 apud Lima, 1978, p. 71).

47 "A escola unificada não permite ainda, entre alunos de um e outro sexo, outras separações que não sejam as que aconselham as suas aptidões psicológicas e profissionais" (Manifesto dos Pioneiros da Educação Nova, 1932 apud Lima, 1978, p. 71).
} 
E os católicos assim se defendiam, como resume Cury:

A adoção da escola leiga, num país católico, é a adoção da escola anticatólica e fere os princípios do próprio liberalismo que o Estado defende. Neste caso, a família católica é ofendida e sua consciência é obrigada a fundar escolas particulares, a fim de salvaguardar os interesses do ideal religioso. (Cury, 1978, p. 154).

Em relação à coeducação, os católicos, na visão dos Pioneiros, estariam confundindo uma questão que seria pedagógica como se fosse de ordem moral (Romanelli, 2009). Na visão católica do período, isso levaria à promiscuidade $\mathrm{e}$ imoralidade, os reformadores defenderiam a educação física e sexual "sem as bases familiares e os princípios intangíveis da moral cristã" (Cury, 1978, p. 155). Para os Pioneiros, o grupo católico ao defender a escola tradicional, colocava-se ao lado da velha ordem social brasileira. E para os católicos, os Pioneiros negavam a dimensão espiritual do ser humano que deveria ter proeminência e também era característica dos brasileiros, limitando-se ao natural e ao terreno. Para os reformadores, o ser humano era dotado de funções mentais, capaz de, pelo conhecimento, modificar a natureza; e vitais.

Os Pioneiros compreendiam o Estado como tendo um papel socializador fundamental e a escola como a principal maneira de integração do indivíduo em relação ao meio. Os católicos partiam, segundo Carlos Roberto Jamil Cury, da aceitação e defesa de Deus enquanto "luz natural" da razão e sua revelação no Cristo e na sua Igreja, a católica. Logo, qualquer consideração educacional, moral ou política que queira levar a uma transformação individual ou social deveria partir também desse pressuposto. O ponto de partida dos Pioneiros era a ciência e o método experimental. Para o grupo de intelectuais católicos, os Pioneiros defenderiam implicitamente um ateísmo, por isso a insistência no "laicismo de educação" que faziam pelo menos indiretamente a partir do materialismo e positivismo (Cury, 1978, 135). A preocupação dos escolanovistas era, todavia, antropocêntrica e qualquer consideração teológica ou mística deveria ser respeitada, mas não poderia ser assumida pelo Estado democrático. A laicidade garantiria a liberdade de culto no lar ou no templo e, na visão deles, o Estado deveria permanecer imparcial, principalmente numa sociedade, como eles observavam, cada vez mais pluralista (Cury, 1978, p. 136). 
Os católicos criticavam a dependência estrangeira do pensamento renovador ao dizer que suas teorias viriam de países protestantes e, por isso, não se identificam com a "alma católica" do povo brasileiro. O fim da educação, para os católicos era a formação integral dos indivíduos e isso significava partir de uma educação cristã e católica, por isso a disputa pelo Ensino Religioso era tida como tão importante, é a "luta para a regeneração da nacionalidade brasileira" (Cury, 1978, p. 148). Os escolanovistas, todavia, não aceitariam que a salvação nacional estaria nas mãos da religião e da moral, fiadores do civismo e da ordem social. Os reformadores pensavam que isso já não era mais a questão do momento, essa era a hora de fornecer aos indivíduos formas de participar, de acordo com suas potencialidades, naquilo que a sociedade precisava ${ }^{48}$. $\mathrm{O}$ grupo católico, nesse período, buscava salvar o Brasil do "individualismo liberal" e do "comunismo ateu". Entre os seus opositores estariam: os positivistas, os liberais, os protestantes, os agnósticos e os maçons. O objetivo dos Pioneiros era o de construir uma democracia social. Para os católicos, os intelectuais da Escola Nova pensariam que o catolicismo era para o povo, para as mulheres e crianças, para os ignorantes, não mais para os "homens da nova civilização" (Cury, 1978, p. 152). O ideal liberal dos reformadores, conscientemente ou não, levaria ao comunismo.

Os intelectuais católicos entendiam que a existência do Ensino Religioso nas escolas privadas era injusta porque ele seria um direito intangível de todos os indivíduos e garantia para a moralidade. Além disso, onerava a maioria católica que acabava tendo que custear a escola pública pelos impostos e pagar pelo ensino privado (Cury, 1978). Uma vez que, a família passou a ser vista como a primeira responsável pela educação dos filhos e a educação fora do lar supunha a continuidade da orientação iniciada pelos pais. Inclusive os direitos do Estado eram vistos como limitados pelos direitos anteriores e superiores da família e da Igreja (Cury, 1978, p. 162). Os Pioneiros reconheciam a importância da família na educação, também sua impossibilidade de garantir a eficiência e integração necessária de uma sociedade que se complexificava cada vez mais. O "manifesto" tolerava a existência de escolas particulares. Mas era muito clara a defesa da escola pública, aberta a todos.

\footnotetext{
48 Eram funcionalistas nesse quesito.
} 
A Constituição sancionada de 1934 foi fruto de uma primeira leva de acirrados debates entre o grupo católico e os reformadores. D. Leme criou a Liga Eleitoral Católica, a LEC, como ficou conhecida. O seu objetivo era o de instruir os votos dos católicos durante a Assembleia Nacional Constituinte e influenciar os deputados candidatos a se comprometer ativamente com a agenda católica para o Brasil naquele momento. Foi assim que, além dos candidatos católicos, constituintes não católicos defenderam o "programa mínimo" católico (Cury, 1978). Em contrapartida, os reformadores eram os "técnicos" e tinham a seu favor os republicanos com o espirito de 1891, os anticlericais, os católicos liberais, os representantes de outros credos, da maçonaria e mesmo os de esquerda ${ }^{49}$. A maioria dos eleitos, no entanto, foi apoiada pela LEC.

O Memorial enviado à Comissão encarregada do anteprojeto da Constituição, considerado um documento do grupo católico, apesar de não se apresentar dessa forma, possuía quatro artigos, conforme nota Danilo Lima (1978): 1) é tarefa da União promover, orientar e dirigir a instrução colaborando com os estados e os municípios, mas sem especificar, o que, na visão do autor, demonstra o receio da presença do Estado em relação à educação; 2) essa seria uma responsabilidade primeira da família que pode ser cumprida por escolas públicas, particulares ou mesmo o próprio lar, o Estado atuaria de forma subsidiária para quem precisasse; 3) assegurada então a liberdade de ensino e afastado o perigo do monopólio do Estado, deixando aberta a atuação das escolas particulares; 4) defesa do Ensino Religioso enquanto uma disciplina obrigatória para os alunos que solicitarem. Tal documento foi subscrito por mais de 700 assinaturas de professores e intelectuais.

A Constituição sancionada de 1934 em grande medida, refletiu a vitória dos Pioneiros: pela primeira vez, tornou-se responsabilidade da União fixar uma política nacional de educação a partir do Plano Nacional de Educação (PNE), além de coordenar e fiscalizar a sua execução; a educação foi proclamada como "direito

\footnotetext{
${ }^{49}$ Dentre eles, um protestante, Guaraci Silveira. Pastor, foi organizador e presidente da Igreja Metodista do Brasil em 1926, liderando o movimento emancipador dessa Igreja no Brasil. Elegeuse deputado à Assembleia Nacional Constituinte em 1933 e 1945. Ocupou muitas vezes a tribuna para defender o divórcio e a separação entre a Igreja e o Estado. Escreveu em diversos jornais e revistas. Em 1944, participou da fundação do Partido Trabalhista Brasileiro (PTB). Liderou ainda a criação do Partido Republicano Trabalhista (PRT), que, mantendo sempre ligações com grupos protestantes, transforma-se em 1958 no Partido Rural Trabalhista. Disponível em: http://www.fgv.br/cpdoc/acervo/dicionarios/verbete-biografico/silveira-guaraci.
} 
de todos", pelo menos no ensino primário; expandiu o ensino secundário, ainda que com conteúdo enciclopédico e com um sistema de avaliação extremamente rígido; vinculou-se $20 \%$ dos recursos dos estados para a educação e $10 \%$ dos recursos do governo federal. Por último, os católicos também tiveram sua vitória conseguindo a aprovação de quase todos os itens do Memorial. O Ensino Religioso permaneceu uma disciplina facultativa nos horários regulares das escolas públicas primárias, secundárias, profissionais e normais (Cury, 1978; Marcílio, 2005), apesar da escolha dos pais, na prática o catolicismo era ministrado. Luiz Antônio Cunha interpreta o retorno do Ensino Religioso nas escolas públicas como uma "pedagogia preventiva", dadas as crescentes atuações dos movimentos sociais que, na visão das elites dirigentes, seriam ameaçadores da ordem social ${ }^{50}$. Abriu-se a possibilidade de subvenções oficiais para entidades particulares por meio da tese da "colaboração recíproca", que (Cury, 1978, p. 120). Foi colocada também explicitamente o reconhecimento da família como educadora nessa Carta Constitucional.

Por conseguinte, aos poucos, a atuação de religiosos e leigos católicos foi se tornando mais comum. A Confederação Católica Brasileira de Educadores (CCBE), dissidência da ABE, teve seu primeiro Congresso em setembro de 1934, existiu até 1937. Nesse meio tempo, organizações laicas foram perseguidas ou tiveram que diminuir muito a sua atividade, algumas foram fechadas e tiveram seus dirigentes presos. A Ditadura do Estado Novo buscou obter diretamente o consentimento das massas, mas não descartou a ajuda a Igreja Católica (Cunha, 2013). Houve incentivo governamental para que as escolas católicas expandissem a sua rede, principalmente de ensino secundário e normal, o que denota a inclinação da formação das professoras primárias.

A nova Constituição outorgada, de 1937, previa a obrigatoriedade do ensino cívico em todas as escolas, públicas e privadas. O Ensino Religioso continuava facultativo, mas pela primeira vez obteve o status de disciplina escolar. A gratuidade do ensino teve um texto ambíguo, o dever do Estado em relação à educação tornou-se supletivo. Com as escolas públicas pagas ${ }^{51}$, os mais ricos financiariam os estudos

\footnotetext{
${ }^{50} \mathrm{Não}$ podemos esquecer que no início do período republicano eclodem muitos movimentos sociais das mais variadas vertentes, tais como operário em grande medida anarquista, o socialista e o de Canudos, com forte teor religioso.

${ }^{51}$ Por meio da contribuição para a chamada "caixa escolar".
} 
de seus filhos, deixando para os mais pobres o ensino profissional que muito se expandiu nesse período com a cooperação entre Indústria e Estado ${ }^{52}$ (Marcílio, 2005). Cada vez mais se percebia a educação como motor para o desenvolvimento nacional e como veículo de ascensão social e moral do indivíduo (Cury, 1978). O Código Penal de 1940, que entra em vigor em 1942, mantém a repressão às religiões de matriz afro-brasileira, em termos pejorativos que indicavam "charlatanismo, curandeirismo e exercício da medicina ilegal como crimes" (Oliveira, 2015, p. 105).

O Ministro Gustavo Capanema realizou reformas parciais entre 1942 e 1946: o ensino secundário passou a ter a função de trazer aos adolescentes uma sólida cultura geral: a consciência patriótica e a consciência humanística; o Ensino Religioso continuou facultativo e livre, isto é, ministrado de acordo com a confissão declarada dos alunos e aconselhou-se a separação de meninos e meninas nessa segunda etapa de ensino (Marcílio, 2005). Tornou-se obrigatória a educação militar para os meninos durante o secundário, com diretrizes pedagógicas fixadas pelo Ministério de Guerras (Romanelli, 2009) e foi inserida a Educação Moral e Cívica. Tanto os princípios fascistas e autoritários eram influência nesse período, quanto a própria Igreja Católica. Os educadores liberais, defensores da Escola Nova afastaram-se do governo federal nessa época. Para os católicos, o ensino técnico foi encarado como um dos fatores da laicização do ensino. Um amplo documento enviado por Amoroso Lima ao Ministério solicitava uma "filosofia sã", "rigorosa exclusão do ecletismo pedagógico e muito menos bolchevismo", "a faculdade do Ensino Religioso em todo o país", a "defesa das humanidades clássicas, latim e grego, e sua incorporação no plano nacional de educação" (Azzi, 2008, p. 312). Lourenço Filho, no entanto, ligado ao movimento renovador, preocupou-se com os aspectos técnicos da educação, o que garantiu que atuasse também durante o Estado Novo.

Segundo Riolando Azzi (2008), os dois Ministros da Educação de Vargas, Campos e Capanema, católicos, foram vistos como pontos de apoio importantes para o aumento da influência dos católicos no governo federal. A crença era um grande dispositivo para a obtenção da ordem pública, na visão deles, para a coesão da

\footnotetext{
${ }^{52}$ É desse período, mais precisamente de 1942, a criação do Serviço Nacional de Aprendizagem Industrial (SENAI) e de 1946 a criação do Serviço Nacional de Aprendizagem Comercial (SENAC).
} 
sociedade. Apesar das ideias do primeiro sintonizarem com a Escola Nova, era autoritário em sua conduta política e liberal quanto à educação. Capanema inclusive assumiu em 1934 como parte do acordo que estabelecia aliança entre a Igreja e Vargas. A saber, apoio em troca do Ensino Religioso. Gustavo Capanema era muito próximo de Amoroso Lima, que foi o intermediário das reivindicações católicas e incentivou que a educação pública brasileira seguisse tal orientação religiosa (Paiva, 2010). No entanto, a posição de Vargas era clara: recebia o apoio da Igreja Católica, mas sem aceitar a influência da Igreja no Estado.

\section{2 .2}

\section{Mais uma vez convocados: pioneiros, católicos e donos das escolas particulares em torno da Lei de Diretrizes e Bases da Educação}

Após a deposição de Vargas, retomaram-se os debates em relação à educação e o ideário reformista ganha novo fôlego. O Ministro do Governo Dutra, Clemente Mariani, foi assessorado por Lourenço Filho e Anísio Teixeira, figuras cruciais do movimento pela Escola Nova. O centro da política foi a educação popular, assumida como “missão civilizatória” (Marcílio, 2005). O sufrágio universal, no entanto, não incluiu os analfabetos ${ }^{53}$, o voto rural, onde estava a maioria dos analfabetos, foi muito restringido. O eleitorado da burguesia industrial era praticamente só urbano.

Com a Assembleia Constituinte de 1946 novamente se instituiu a já antiga disputa sobre a laicidade do ensino público. $\mathrm{O}$ auge foi a discussão sobre o Ensino Religioso, defendido pelos deputados constituintes apoiadores da LEC. O texto constitucional aprovado era exatamente como havia sido proposto pela LEC anos antes, de matrícula facultativa e de acordo com a confissão religiosa do aluno. O movimento dos educadores defensores da Escola Nova também teve algumas vitórias na Constituição de 1946: a educação voltou a ser definida como direito de todos, o ensino primário voltou a ser obrigatório e o oficial voltou também a ser gratuito para todos e o secundário gratuito quando se provava insuficiência de recursos. Previa-se ainda a criação das Diretrizes e Bases da Educação Nacional.

\footnotetext{
53 Os analfabetos só puderam votar a partir da Constituição de 1988.
} 
A Encíclica Divini Illius Magistri ${ }^{54}$, de 1929, "sobre a educação cristã da juventude", era o que influenciava a Igreja Católica brasileira no quesito educacional durante o período em questão. Indicava a defesa de recursos públicos para viabilizar as obras da Igreja (Lima, 1978, p. 45). Dizia que o dever de educar, visto aqui como quase um sinônimo de educação cristã, compete respectivamente à Igreja, a família e, de modo subsidiário, ao Estado, devendo a escola ser extensão da Igreja e da família (Lima. 1978, p. 57). Objetivava-se construir uma sociedade cristã e indivíduos considerados verdadeiramente cristãos, daí a defesa das escolas católicas e a proibição dos filhos de católicos em frequentar escolas laicas e que tivessem a educação sexual ${ }^{55}$ e a coeducação ${ }^{56}$. Por outro lado, um novo Manifesto foi defendido pelos educadores escolanovistas, escrito novamente por Fernando de Azevedo no ano de 1959 e assinado por 189 pessoas. Traziam mais uma vez à tona a defesa da escola pública, a liberdade de ensino, a educação liberal e democrática, mas principalmente o aspecto social da educação e os deveres do Estado em assegurá-la para todos.

Para a confecção do que seria a nossa primeira Lei de Diretrizes e Bases da Educação (LDB), o Ministro Mariani convocou uma comissão de grandes educadores que foi presidida por Lourenço Filho, a maior parte dos intelectuais dessa comissão eram adeptos à Escola Nova, três membros eram da Igreja Católica ${ }^{57}$. O projeto entrou na Câmara dos Deputados em 1948 e só conseguiu ser

\footnotetext{
${ }^{54}$ Escrita pelo Papa Pio XI, o mundo é visto como integral e cristão e as exceções são minoria. A educação vinculada aos princípios cristãos é colocada como a única possível (Lima, 1978).

55““Assaz difuso é o erro dos que, com pretensões perigosas e más palavras, promovem a chamada educação sexual, julgando erradamente poderem precaver os jovens contra os perigos da sensualidade, com meios puramente naturais, tais como uma temerária iniciação e instrução preventiva, indistintamente para todos, e até publicamente, e pior ainda, expondo-os por algum tempo às ocasiões, para os acostumar, como dizem, e quase fortalecer lhes o espírito contra aqueles perigos" (Pio XI, Divini Illius Magistri, Petrópolis, Vozes, 1947, par. 8, p. 13 apud Lima, 1978, p. 59).

56“'De modo semelhante, errôneo e pernicioso à educação cristã é o chamado método da 'coeducação', baseado também para muitos no naturalismo negador do pecado original e ainda para todos os defensores deste método, sobre uma deplorável confusão de ideias que confundem a legítima convivência humana com a promiscuidade e igualdade niveladora. O Criador ordenou e dispôs a convivência perfeita dos dois sexos somente na unidade do matrimônio e gradualmente distinta na família e na sociedade (...). Estes, segundo os admiráveis desígnios do Criador, são destinados a completar-se mutuamente na família e na sociedade, precisamente pela sua diversidade, a qual, portanto, deve ser mantida e favorecida na formação educativa, com a necessária distinção e correspondente separação, proporcionada às diversas idades e circunstâncias”. (idem, par. 66-9, p. 27 e 28 apud Lima, 1978, p. 60).

${ }^{57}$ Padre Leonel Franca na Subcomissão de Ensino Superior, Alceu Amoroso Lima e Maria Junqueira Schmidt na subcomissão de Ensino grau médio (Lima, 1978, p. 90).
} 
aprovado 13 anos depois, em 1961. Maria Luiza Marcilio aponta que a velha questão da laicidade do Estado foi, nessa segunda fase, revestida de uma roupagem nova. A saber, o grupo católico, dominante na discussão por meio da iniciativa privada não-confessional, colocou-se a favor que se limitasse a atuação do Estado no campo educacional e tentou garantir subsídios públicos para as escolas privadas (Cunha, 2013). Nesse período, a Igreja ainda se comprometia com uma perspectiva de organização social hierarquizada, a partir da formação de uma elite dirigente a qual deveria ser educada sob os seus preceitos (Marcilio, 2005, p 150).

Foram duas as fases da discussão: a primeira delas, a concepção centralizadora, herdeira de 1937 versus a concepção federativo-descentralizadora, que tinha como norte a doutrina constitucional de 1946; a segunda se deu a partir da apresentação do substitutivo do então deputado Carlos Lacerda contra o monopólio estatal e em favor das instituições particulares de ensino. Teve direito à arquivamento e retomada, à anexação de outro projeto feito pela Associação Brasileira de Educação, à participação de vários educadores em plenárias. $\mathrm{O}$ anteprojeto propunha a criação de um Conselho Nacional de Educação que deveria assessorar o ministro, além disso, a formação de um sistema federal de ensino e os estados também teriam os seus próprios sistemas, a União atuaria de forma supletiva quando necessário. $\mathrm{O}$ impasse foi tão grande que tal projeto acabou sendo deixado de lado.

De 1958 para frente, entrou na ordem do dia o substitutivo de Lacerda sobre a "liberdade de ensino", liberdade aí entendida como o direito de qualquer instituição, para além do Estado, em ensinar (Romanelli, 2009, p. 174). A ele se relacionavam os também previstos: direitos da família em relação à educação dos filhos, a escola era tida como prolongamento e delegação da família; a atribuição do Estado em fornecer às novas gerações o ensino oficial gratuito ou estimular à iniciativa particular. Reivindicavam-se recursos públicos para o ensino privado, antes mesmo do benefício do ensino oficial.

Em resumo, partia-se do direito da família e da liberdade de ensino para requerer uma igualdade absoluta de condições entre a educação pública e privada, isto é, discutia-se o próprio destino da educação pública (Romanelli, 2009). A ideia de "liberdade de ensino" contida no substitutivo era basicamente a mesma dos 
documentos papais: "exclusiva liberdade da Igreja de exercer a ação educativa" (Spencer, 1960 apud Romanelli, 2009, p. 177). Se no Brasil, a Igreja não poderia requerer tal exclusividade, ela passou a endossar a luta contra o monopólio do Estado em relação à educação escolar. Essa era uma oportunidade para retomar a influência até pouco tempo atrás exercida pela Igreja Católica no sistema educacional e na política como um todo. Para tanto, tal instituição apostava na tradicional sociedade católica brasileira. Além disso, tal argumentação interessava aos donos dos estabelecimentos particulares de ensino que acabaram por fazer coro aos ideais católicos. Embora a Constituição de 1946 falasse explicitamente da liberdade da iniciativa privada no ensino e o Estado brasileiro jamais tenha exercido o monopólio da educação escolar, nunca tendo efetivamente direcionado recursos para realizá-lo.

Uma nova configuração foi formada entre os católicos, com a morte de D. Leme e o afastamento de Amoroso Lima, outras lideranças surgiram e ocupavam cargos na Associação de Educação Católica (AEC) criada em $1945^{58}$, na Confederação Nacional dos Bispos Brasileiros (CNBB) fundada em 1952 e na Conferência dos Religiosos do Brasil (CRB) de 1954. Especialmente a primeira, fundada pelo padre Artur Alonso Frias ${ }^{59}$ teve atuação direta no debate sobre a LDB.

Os Pioneiros, agora renovados com alguns dos antigos e outros novos, como Florestan Fernandes e outros intelectuais da Universidade de São Paulo (USP), além de estudantes e líderes sindicais, reunidos em 1960 na Campanha em Defesa da Escola Pública, apresentaram um substitutivo por meio do deputado Celso Brant que se assemelhava ao antigo anteprojeto. Os pontos relacionados ao direito da família e o favorecimento da escola privada por meio do recebimento de recursos foram mantidos. Dividiram-se educadores em favor da necessidade do Estado em assumir a função educativa de um lado, e educadores católicos, nesse momento, coadjuvante em relação aos donos de escolas particulares, que viam na estratégia de defender o direito da família uma forma de conseguir garantias para o ensino privado. A própria AEC encarregou-se de encontrar uma conciliação entre os líderes da Câmara, chegando a um resultado que a agradava.

\footnotetext{
${ }^{58}$ Substituiu a antiga CCBE e teve uma atuação muito mais dinâmica em relação à antiga associação. ${ }^{59}$ Por alguns anos reitor da PUC-Rio e presidente da AEC.
} 
Segundo Danilo Lima, nem os educadores religiosos entraram ingenuamente nessa disputa e ela também não pode ser reduzida a uma competição por recursos apenas. Até porque a AEC exercia uma influência de peso nas organizações de instituições particulares de ensino. Na sua visão, os educadores católicos partiam de uma visão elitista do sistema educacional, que beneficiava principalmente as elites e se estendia de forma caritativa aos mais pobres. Logo, sua ação era supletiva nesse campo e para além dos princípios defendidos na Encíclica Divini Illius Magistri, a Igreja possuía três séculos de prática educativa: seletiva, privada, acadêmica, dualista, mas por muito tempo a única. A Igreja era uma instituição legitimada enquanto educadora por ter sido reconhecida há muito em formar as elites dirigentes brasileiras, a escola pública oficial "ameaçava" essa imagem, apenas a manutenção dos dois sistemas - o público e o privado - e a captação de recursos públicos, garantiria a manutenção do status anterior da Igreja Católica.

A LDB aprovada de 1961 previu como um dos fins da educação a condenação de qualquer tratamento desigual por conta de convicção filosófica, política ou religiosa ou preconceito de classe ou raça. Manteve-se o direito do Estado em fiscalizar a educação particular. O ensino primário deixou de ser obrigatório, o que foi uma perda num momento em que ainda os mais pobres mal chegavam a essa etapa escolar e as taxas de analfabetismo se mantinham altas. A liberdade de ensino manteve-se tal qual o substitutivo do deputado Carlos Lacerda, como também foi retirada a autonomia de recursos da esfera pública para privilegiar a esfera privada. Consolidava-se o projeto dual de educação e sociedade: formação de uma elite dirigente e de uma camada que serviria como força produtiva para um país que se modernizava de forma conservadora. Marcílio aponta, contudo, que a LDB representou um inegável avanço quanto a unificação do sistema escolar brasileiro, dos sistemas federais em relação aos sistemas estaduais de ensino. E para Romanelli, o balanço do resultado final da LDB foi negativo, apesar de enfatizar o caráter altamente produtivo dos debates antes da promulgação que teve no encontro da velha geração de 1930 com uma nova geração, da qual fizeram parte não só intelectuais, como estudantes e operários.

Além dos grupos hegemônicos, como chama atenção Danilo Lima, os grupos da Juventude Universitária Católica (JUC) tiveram uma atuação desviante em relação 
à cúpula da hierarquia eclesiástica na fase final da discussão sobre a LDB. Mas, segundo aponta Angela Paiva, os militantes jucistas ${ }^{60}$ que se colocaram a favor da autonomia da educação nacional não possuíam autonomia para atuar e acabaram sofrendo uma censura eclesiástica. A essa altura já se começava a ter uma crítica à Encíclica Divini Illius Magistri, feita por movimentos que culminarão na Declaração do Concílio Vaticano II Gravissimum Educations ${ }^{61}$ em 1966.

Em outras palavras, a mudança de orientação de Roma ocorria no mesmo período em que no Brasil se travam as disputas relacionadas à nossa primeira LDB. Tal Declaração fala de uma sadia educação sexual ${ }^{62}$; admite o controle do Estado na formação dos professores e na fiscalização das escolas particulares; defende também as escolas confessionais, mas de maneira mais moderada; separa o direito de todos à educação e o direito dos cristãos à uma educação cristã; os responsáveis pela educação são respectivamente em ordem de importância a família, o Estado e a Igreja. Um terceiro documento que trata de educação, que irá influenciar mais à frente, é o referente à II Conferência Geral do Episcopado Latino-Americano realizado em Medellín em 1968. No qual evoca-se a necessidade de uma educação que crie o espirito crítico ${ }^{63}$.

\footnotetext{
${ }^{60}$ Dentre eles, o Diretório Central dos Estudantes (DCE) da PUC-Rio.

${ }^{61}$ Propôs a visão pastoral, a saber, olhar a realidade antes de pensar sobre o que se pode fazer com ela. Os problemas da educação passaram a ser percebidos como parte da missão da Igreja em anunciar a salvação. Tomou-se conta da diversidade de ouvintes e de seus pontos de vista, o mundo começou a ser visto de forma plural e "o povo de Deus é chamado no Evangelho de Cristo a colaborar na construção de uma sociedade mais justa". A educação passou a ser vista como um direito universal (Lima, 1978, p. 55).

62“"sadia educação sexual de acordo com os progressos da psicologia, pedagogia e didática, há de dar-se assistência às crianças e aos jovens para desenvolverem harmoniosamente seus dotes físicos, morais e intelectuais, para adquirirem gradativamente um senso mais perfeito de responsabilidade, (...). De acordo com a idade sejam preparados por uma educação sexual positiva e prudente. Além disso, sejam treinados de forma a participarem da vida social. Assim, (...) estejam habilitados a entrosar-se ativamente nos diversos grupos da comunidade humana, abrindo-se para o diálogo com os outros e empenhando-se com gosto no esforço de promover o bem comum" (Concílio Vaticano II, Declaração Gravissimum Educations, 1966, par. 1 p. 5 apud Lima, 1978, p. 60).

63“"os métodos didáticos estão mais preocupados com a transmissão dos conhecimentos do que com a criação do espírito crítico. Sob o ponto de vista social, os sistemas educativos estão orientados à manutenção das estruturas sociais e econômicas reinantes, mais do que à sua transformação (...). A educação em todos os seus níveis deve chegar a ser criadora, enquanto deve antecipar o novo tipo de sociedade que buscamos na América Latina; deve basear seus esforços na personalização das novas gerações, aprofundando a consciência de sua dignidade humana, favorecendo sua livre autodeterminação e promovendo seu senso comunitário" (II Conferência Geral do Episcopado Latino-americano, em Medellín, SEDOC, v. 1, f. 5, novembro de 1968, col. 687-694 apud Lima, 1978, p. 62).
} 
Junto com esse início de virada, durante a década de 1960 iniciaram-se Campanhas e movimentos de alfabetização de adultos reunidos no Movimento de Educação de Base (MEB) que passou a ter um compromisso de transformação do meio rural nordestino. Foram esforços de renovação escolar, sobretudo em termos de educação de adultos (Azzi, 2008, p. 153) e envolveram universitários e professores, leigos e religiosos, membros da Ação Católica (AC) e Ação Popular (AP). Inclusive aderindo uma postura pioneira da educação popular que se interrompeu com a Ditadura de 1964. Contudo, ainda assim, o peso maior da Igreja continuava a se manter numa posição nitidamente conservadora (idem, p. 324), mas, como chama atenção Angela Paiva, esse é o início de um movimento renovador que traz matizes modernizadoras para dentro da institucionalidade católica do período que passou a questionar o que era ser cristão apontando para um maior engajamento social, na medida em que se passava a perceber as desigualdades brasileiras. E, além disso, uma primeira iniciativa da Igreja Católica para a promoção da educação de massa, por tanto tempo excluída de suas prioridades.

O governo de João Goulart quis aproveitar a experiência do MEB para a criação de uma política de educação de adultos em âmbito nacional. Muitos da JUC e da AP colaboraram, inclusive Herbert de Souza, o Betinho, então coordenador de assessoria do Ministro Paulo de Tarso. O convidado para coordenar o programa foi Paulo Freire. Para a cúpula oficial, tais reformas foram interpretadas como "perigo comunista". E conclamou os seus fiéis para a "Marcha com Deus pela liberdade".

Em contraposição à ação mais progressista da Igreja Católica, veio para o Brasil também na mesma época, em 1969, a Renovação Carismática, iniciada por aqui por membros da própria hierarquia da Igreja ${ }^{64}$, com inegável influência de pastores protestantes que se tornaram adeptos do neopentecostalismo. Primeiro em São Paulo e Campinas e por meio de retiros e Congressos foram se espalhando pelo resto país. Possuem vários pontos de contato com o protestantismo, principalmente o pentecostalismo, tais como a ênfase na transcendência imediata, crenças na cura

\footnotetext{
${ }^{64}$ Originária da cidade norte-americana de Pittsburgh em 1967, teve a Universidade de Duquesne como nascedouro. Por meio de alunos e professores que se dedicaram a "buscar o Batismo no Espírito Santo" e ao desenvolvimento de dons carismáticos, a partir de leituras das publicações pentecostais e da participação em encontros Inter denominacionais. Aos poucos, criou grupos católicos e passou a se expandir por meio de "pequenos grupos de oração" e a organização de encontros nacionais e internacionais. (Machado, 1996, p. 46-48).
} 
por meio dos "Dons do Espírito Santo", militância religiosa, valorização da Bíblia e influência do pietismo. Por outro lado, os carismáticos católicos diferenciam-se pela estrita obediência ao Papa e a devoção à Maria, o que lhes denotou forte identidade (Machado, 1996, p. 79).

\section{3 \\ Protestantismo e educação: o início da mudança no campo religioso brasileiro}

Como bem lembra Maria Luiza Marcílio (2005), o período de colonização do Brasil é o mesmo que ocorria em alguns lugares da Europa, especialmente na Alemanha, a Reforma Protestante. Investiu-se por lá, nesse período, na difusão da instrução, fundamental para que cada indivíduo pudesse ler e interpretar a Bíblia. É justamente daí, segundo a autora, que surgirão as iniciativas mais avançadas no que tange à instrução popular e moderna pelo empenho inclusive das recém-formadas ordens religiosas. Já em 1763, por exemplo, Frederico II da Prússia secularizou de vez a educação e instituiu a obrigatoriedade escolar universal para crianças de 5 a 13 anos. Para os protestantes a alfabetização se torna premissa crucial para o exercício de sua fé. No Brasil, de forma incipiente, os protestantes também tiveram participação nos momentos históricos anteriormente citados. De maneira que essa presença tenha servido como princípio do maior protagonismo evangélico hodiernamente. Torna-se de grande importância retomá-la para se construir o cenário com os diferentes atores envolvidos na relação entre religiões e a educação escolar na história do Brasil.

Pode-se dizer que a história do Protestantismo em suas diversas manifestações ${ }^{65}$ iniciou-se por aqui somente no século XIX. Antes da separação oficial entre Estado e Igreja, teremos apenas esparsas tentativas, como as invasões francesas no Rio de Janeiro entre 1555 e 1557, que tentaram instalar uma colônia huguenote; e também as expedições holandesas na Bahia e Pernambuco entre 1624 e 1630 com os princípios calvinistas, realizando inclusive uma espécie de catecismo para as tribos dessas regiões. Porém, nenhuma das duas invasões possibilitaram o culto protestante de maneira permanente.

\footnotetext{
${ }^{65}$ Como assinala Prócoro Velasques Filho e Antônio Gouvêa Mendonça (1990), falamos em vários protestantismos e não em um só.
} 
A vinda da Corte portuguesa em 1808 foi o primeiro marco para o fim da exclusividade católica, já que o acordo com os ingleses, apesar de grande oposição, previa a liberdade dos súditos britânicos em celebrar a sua fé nas próprias igrejas e capelas, desde que elas fossem construídas de maneira discreta e parecessem residências ${ }^{66}$ (Ramalho, 1976; Cunha, 2013). Mais à frente, no período regencial, Feijó tentou sem sucesso trazer missionários moravianos ${ }^{67}$, o que já indicava o cansaço com os jesuítas. Durante o Império ainda, D. Pedro II, inspirado em princípios liberais, intencionava atrair para o Brasil os imigrantes protestantes, muito apreciados pelos seus conhecimentos e serviços práticos que poderiam prestar (Ramalho, 1976). A já então desgastada relação entre a Igreja e o Estado ${ }^{68}$ teve mais um episódio frustrado de disputa para que se afrouxasse a lei de liberdade de culto. Chegando-se a deixar de ser obrigatório o Ensino Religioso no Colégio Pedro II em 1878 (Miranda, 1966, p. 61).

Além dos ingleses, vieram para cá norte-americanos e alemães, mas, ainda assim, a maior parte do fluxo migratório foi mesmo de católicos. Duas capelas tinham sido abertas pelas colônias estrangeiras, a dos anglo-saxões em 1819 e a dos alemães em 1837. Anos depois, em 1855, os cultos começaram e ser feitos em língua portuguesa (Ramalho, 1976). O segmento liberal brasileiro ansiava por uma educação que substituísse o sistema escolástico jesuíta e tomasse as rédeas do caminho para a educação pragmática (Mendonça, 1990, p. 74). Aos poucos, começaram a se instalar outras religiões por meio das migrações ou então a partir de missões principalmente norte-americanas ${ }^{69}$, não só no Brasil, como na América Latina como um todo ${ }^{70}$ : luteranos em 1823, metodistas em 1835, congregacionais em 1855,

\footnotetext{
${ }^{66}$ Os ingleses não poderiam "ser perturbados, inquietados, perseguidos ou molestados" por causa da sua religião, podendo gozar de inteira liberdade de consciência (Ramalho, 1976, p .52).

${ }^{67}$ Uma denominação protestante da Boêmia, atual República Checa.

${ }^{68}$ Nos anos de 1872 e 1875, houve o que se chamou de "questão religiosa", eclodida com a suspensão pelo bispo do Rio de Janeiro de um padre maçom. O primeiro era ferrenho adepto do ultramontanismo, a doutrina que postulava a infalibilidade do papa e combatia ideias e instituições liberais e racionalistas associadas à secularização e ao anticlericalismo, uma das principais: a Maçonaria. Abriu espaço para a perseguição de outros padres maçons chegando a críticas públicas e o questionamento do reconhecimento do Governo, o que levou à condenação de dois bispos. (Basile, 1990, p. 277).

${ }^{69} \mathrm{~A}$ instalação do protestantismo no Brasil foi a materialização das lutas teológicas travadas na igrejas norte-americanas. Como salienta Antônio Gouvêa Mendonça, provavelmente o que aqui chegou não deviam ser os mais privilegiados pensamentos teológicos daquele país. Mas sim ideias vencidas, minoritárias e residuais que por aqui prevaleceram.

${ }^{70}$ Os missionários contribuíram para que se introduzisse o vocábulo "crente" entre aqueles que se convertessem. Esse era alguém tinha abandonado suas antigas crenças e passava a "crer em Nosso
} 
presbiterianos em 1859, batistas em 1882, episcopais em 1890, espíritas em 1865 e esotéricos em 1909 e no ano seguinte, os pentecostais (Ramalho, 1976, p. 53). Com exceção das três últimas denominações, todas as outras pertencem ao que se convencionou chamar de "protestantismo histórico" que se divide entre o “protestantismo de imigração" e o de "missão".

O primeiro grupo tem nos luteranos o seu mais clássico exemplo e não será objeto desse trabalho. Uma vez que a religião para tais comunidades era uma maneira de preservar a sua própria cultura de origem, eles não vieram para o Brasil com o objetivo principal de converter as pessoas. Instalaram-se No Rio de Janeiro, Rio Grande do Sul, Santa Catarina, São Paulo, Espírito Santo e sul de Minas Gerais. Criaram em suas colônias uma vasta rede de escolas ligadas às paróquias para atender principalmente aos seus próprios filhos, sem fazer a integração inicialmente com o sistema de ensino oficial brasileiro. O segundo grupo, ao qual me deterei mais profundamente, implantou-se por meio de missões, facilitadas por D. Pedro II, em sua esmagadora maioria, norte-americanas, que teve basicamente duas estratégias: 1) a criação de escolas; 2) a conversão direta.

Grande parte dos missionários norte-americanos que vieram para o Brasil pertenciam ao movimento pietista ${ }^{71}$. Segundo Jether Pereira Ramalho (1976), tais denominações têm por característica ação proselitista, ausência de uma reflexão teológica mais elaborada em detrimento de um emocionalismo. Além disso, dão importância à santificação, o que se intensificou no Brasil, dado o monopólio tradicional católico e, por isso, a percepção pelos missionários do país como um lugar "atrasado". Com isso, converter as pessoas seria uma saída para torná-las "bons cidadãos, excelentes patriotas e tementes a Deus" (Ramalho, 1976, p. 62). Eles acreditavam nas missões enquanto uma vocação norte-americana, uma missão divina, de transferir para a América Latina o seu estilo de vida, interpretado como o seu "destino manifesto" (Mendonça, 1990, p. 73). Outros grupos de missionários, os evangelicals, surgidos em princípios do século XIX na Europa e que migraram para os Estados Unidos, chegou ao Brasil no início do século XX, em 1903.

Senhor Jesus Cristo" como um compromisso de mudança de vida. Significava honra, privilégio e respeito, também era um estigma (Mendonça, 1990, p. 15).

${ }^{71}$ Prioriza o sentimento e o misticismo na experiência religiosa, em detrimento de uma construção teológica racionalista. Ênfase na "religião do coração e nas formas de comportamento" (Ramalho, 1976, p. 62). 
Consistiam em ligas e alianças de Igrejas protestantes a partir de alguns fundamentos comuns, com o objetivo de enfrentar a expansão do ultramontanismo ${ }^{72}$ católico, recuperar e preservar a força das Igrejas reformadas e unificar a mensagem religiosa para não causar confusão denominacional nas áreas de missão. Daí surgiu a auto identificação de "evangélico" que se tornou tão comum (Mendonça, 1990, p. 16).

A língua e as doenças foram algumas das dificuldades enfrentadas pelos missionários. Também as leis do Império, que os impedia de construir casas que tivessem fachadas de Igreja, não considerava válidos os casamentos que celebravam e os filhos de tais uniões, os proibiam de pregar suas doutrinas em lugares públicos, dificultava o sepultamento de seus mortos. Ainda assim, convertiam famílias inteiras, membros da elite, comerciantes e fazendeiros. Junto com eles, vinham parte dos seus agregados e trabalhadores agrícolas, que se sentiam atraídos pela maneira calorosa de acolhimento e principalmente pela sua admissão de forma igualitária em relação aos "ilustres" (Leonard, 1963, p. 121 apud Ramalho, 1976, p. 58). Nas cidades, convertiam-se comerciantes, artesãos, operários e militares e católicos e não católicos que já viviam sob a influência das ideias liberais na sociedade brasileira, geralmente brancos. Vários foram os embates jurídicos que acabaram autorizando os pastores a fazer seus casamentos e batismos e construírem os próprios cemitérios de suas denominações. É desse período o ganho de simpatia dos protestantes pelos liberais e pelos maçons (Mendonça, 1990).

Posteriormente, todos os grupos protestantes não se manifestaram contra a escravidão, beneficiando inclusive dela (Branchini, 2013). Num momento em que a população negra era rejeitada das igrejas ou das escolas católicas, os evangélicos os acolhiam. Não sem preconceitos e discriminações (Reina, 2017). Compartilhavam uma visão da época que acreditava na inferioridade cultural do povo negro, que possuía nessa perspectiva, "costumes degenerados e contrários à atitude cristã” (Branchini, 2013, p. 17). A estratégia utilizada era o Ensino Religioso como forma ensiná-los sobre submissão e obediência e também o controle social do grupo religioso, como aponta Diná da Silva Branchini (idem). Maneiras essas

\footnotetext{
${ }^{72}$ Como já dito em nota anterior, a doutrina que prevê a infalibilidade do papa.
} 
de branqueamento cultural ou nos dizeres de Roger Bastide citado pela autora, de "assimilação". A conversão significava o rompimento com a possível identidade negra anterior em favor de uma nova identidade quase exclusivamente religiosa.

Segundo Maria Goreth Santos (2014), o censo de 1872 é considerado o primeiro recenseamento da sociedade brasileira, num momento em que $15,24 \%$ da população era de escravos. Para o registro da religião havia duas opções: "católicos" e “acatólicos". 99,7\% declarou-se na primeira opção, com a ressalva de que como os escravos eram proibidos de professar as suas religiões, foram registrados automaticamente como católicos. O censo de 1890, portanto recém abolida a escravidão, apresenta uma maior distribuição da população entre: católicos romanos: $98,9 \%$; católicos ortodoxos; $0,01 \%{ }^{73}$; evangélicos: $0,13 \%$; outras seitas: $0,85 \%$; ainda houve registro de presbiterianos, islamitas ${ }^{74}$, positivistas: $1.327^{75} \mathrm{e}$ sem culto, o que já uma ideia, segundo a autora, do início de um pluralismo religioso, ainda que muito tímido na declaração.

É a instauração da República que influi de forma crucial para a consolidação e expansão dos protestantes no Brasil. Há registros de diferentes grupos religiosos que se felicitam com este acontecimento ${ }^{76}$ e já era muito grande a rede de colégios de orientação americana nesse período, o que lhes denotava grande "respeitabilidade" em relação ao resto da sociedade. Tais denominações passaram a aparentemente representar uma alternativa inovadora ao monopólio tradicional católico, mais afinadas com o pretenso desenvolvimento capitalista: ideal liberal e democrático, liberdade de expressão, individualismo (Ramalho, 1976). Os católicos, por sua vez, antes mesmo do próprio Estado, tinham como "inimigo número um" a ser combatido quando se tratava de educação escolar, o próprio protestantismo (Azzi, 2008, p. 153). Para eles, a crença protestante era considerada uma heresia, nesse sentido, eles seriam condenados eternamente. E, todos os

\footnotetext{
${ }^{73}$ Por conta da imigração de ucranianos para o Brasil no final do século XIX, daí a aparição de católicos ortodoxos.

${ }^{74}$ Certamente por conta da imigração árabe entre 1850 e 1900.

${ }^{75} \mathrm{Em} 1876$ foi fundada a Sociedade Positivista Brasileira, que depois se transformou em Igreja Positivista do Brasil.

${ }^{76}$ Como exemplo: "A convenção Baptista Brasileira, escolhendo a data da Proclamação da República, declarou por certo, ao menos cinco coisas entre outras: Primeiro: Que o regimem republicano, sendo um regimem democrático - governo do povo e para o povo - é o que está mais de acordo com os princípios do Christianismo..." (Editorial do Jornal Baptista, nov. 1925 apud Ramalho, 1976, p. 59).
} 
valores que pregavam, para a Igreja Católica eram vistos, nesse momento, como fonte geradora da crise moral que afetava o mundo ocidental e o Brasil em particular. Nos documentos oficiais, além de recomendar a escola católica, os bispos condenavam os pais que escolhessem colégios protestantes para os filhos.

O pentecostalismo conseguiu se instalar no Brasil e na América Latina apenas a partir do início do século XX, nesse período as Igrejas históricas já haviam se consolidado. Em pouco tempo, entretanto, as ultrapassam em um crescimento acelerado e impressionante ${ }^{77}$. Sua expansão ocorreu principalmente a partir de 1930 e está intensamente ligada à industrialização e urbanização ${ }^{78}$. O seu boom se deu entre os anos de 1950 e 1970. Suas pequenas Igrejas, geralmente com liderança individual, espalharam-se principalmente nas margens de núcleos urbanos, favelas e periferias, como também em pequenas cidades. Uma de suas divisões se desenvolveu no Paraná, estendendo-se primeiramente para São Paulo, com adeptos entre os imigrantes italianos, orientados por um missionário vindo das colônias italianas de Chicago. E outra, em Belém do Pará, por meio de missionários suecos e norte-americanos. A primeira era a Congregação Cristã do Brasil ${ }^{79}$ fundada em 1910 e a segunda, a Assembleia de Deus ${ }^{80}$, fundada no ano seguinte.

Embora a característica mais comum entre as denominações pentecostais seja justamente a sua diversidade (Machado, 1996, p.44), é quase impossível enumerálas ${ }^{81}$, pode-se elencar as suas principais diferenças em relação aos históricos: o

\footnotetext{
${ }^{77} \mathrm{Em} 1930$, os pentecostais representavam 9,5\% do protestantismo brasileiro, em 1974 eram mais de 70\% dessa vertente religiosa (Ramalho, 1976, p. 64). Com base no último censo, de 2010, hoje são mais de dois terços dos protestantes, cerca de $13,3 \%$ da população brasileira como um todo (Teixeira, 2014).

${ }^{78} \mathrm{~A}$ exemplo de sua origem nos Estados Unidos: “(...) possivelmente o começo foi uma escola bíblica fundada em Topeka (EUA), capital do Estado de Kansas, desde 1881 considerado um importante centro urbano. Depois o ressurgimento religioso atingiu outras cidades dos Estados Unidos (Houston, Texas, Los Angeles) que, ao lado de muitas outras, 'atravessam uma fase de desenvolvimento sumamente veloz' e estavam repletas de imigrantes das zonas rurais do país e da Europa. Os Estados Unidos eram o país das oportunidades e as cidades concentravam todas as esperanças de uma vida nova. Mas o mito de melhorar a situação social superava sempre a realidade, mesmo quando tal realidade existisse. Trata-se de um fenômeno essencialmente urbano" (Cesar, 1974 apud Ramalho, 1976, p. 66).

${ }^{79}$ Dissidência da Igreja Batista, crê na predestinação. Valoriza a cultura oral e se expandiu principalmente entre a massa trabalhadora pobre (Mendonça, 1990).

${ }^{80}$ Dissidência da Igreja Presbiteriana, a mais popular entre as pentecostais até hoje: no último censo, a Assembleia de Deus registrou 12,3 milhões de adeptos (Teixeira, 2014). É conversionista e valoriza a comunicação escrita (Mendonça, 1990). Tanto ela como a Congregação Cristã do Brasil, estimulam a participação emocionada nos rituais, o proselitismo religioso e a rigidez moral (Machado, 1996, p. 45).

${ }^{81}$ No censo de 2010 foram registradas mais de 20 denominações entre pentecostais e neopentecostais. Depois da Assembleia de Deus seguem as mais numerosas: a Congregação Cristã
} 
"batismo do Espírito Santo", os dons espirituais (como a cura, a profecia, a glossolalia e a libertação) e a crença na segunda vinda de Jesus Cristo (Ramalho, 1976) ${ }^{82}$. A importância dada às tais doutrinas fazem com que suas denominações não deem o mesmo valor à construção de escolas como fizeram os grupos protestantes históricos. De acordo com Machado, na segunda metade do século XX, tais denominações romperam os limites do mundo popular e passaram a ganhar adeptos também nas camadas médias brasileiras.

Nos anos de 1960, chegaram ao Brasil as transformações ocorridas logo antes nos Estados Unidos, denominados por alguns como neopentecostalismo e por outros de movimento carismático. Com adeptos principalmente entre a classe média norteamericana $^{83}$, tais grupos passaram a observar a subordinação aos poderes, também pregado pelo pietismo, mas que havia sido deixado de lado pelo movimento anterior. Diferentes denominações históricas passaram a experimentar a experiência pentecostal. No Brasil, entretanto, tais igrejas, principalmente a Batista e a Metodista, recusaram-se a aceitar levando a vários cismas.

A divisão esquemática de Freston (1993), que divide o pentecostalismo brasileiro em três "ondas", pode ser muito útil para resumir e, como colocado por Machado, para resgatar a plasticidade do movimento pentecostal: a primeira coincide com a origem e crescimento do pentecostalismo mundialmente, dá ênfase à glossolalia $\mathrm{e}$ tem como principais representantes: Congregação Cristã do Brasil e a Assembleia de Deus; a segunda onda ocorre na década de 1950 com a Cruzada Nacional de Evangelização ${ }^{84}$, destaca-se pela importância dada ao dom da cura: as principais denominações são a Igreja do Evangelho Quadrangular, Brasil para Cristo e Deus é Amor; a terceira enfoca o exorcismo ou "libertação das forças malignas" 85 e tem

do Brasil, com 2.289.634, a Igreja Universal do Reino de Deus, com 1.873 .243 e Igreja do Evangelho Quadrangular, com 1.808.389 (Teixeira, 2014).

${ }^{82} \mathrm{Os}$ considerados primeiros adeptos do Pentecostalismo defendiam que "falar em línguas", a chamada glossolalia, era um dos sinais do batismo do Espírito Santo. Foi o que ocorreu numa das reuniões em uma igreja pobre de negros em Los Angeles, em 1906 quando um menino de oito anos o fez e foi seguido de outras pessoas (Mendonça, 1990, p.47; Machado, 1996, p. 44 e 45).

${ }^{83} \mathrm{~A}$ universidade teve papel importante nesses debates e a partir desse período se tornará nos Estados Unidos um lugar privilegiado de militância religiosa e evangelização (Machado, 1996).

${ }^{84}$ Idealizado por dois missionários norte-americanos, o "circo gospel" tinha louvores à base de guitarra, foi um evento que juntou centenas de fiéis sob uma lona em São Paulo em 1953.

${ }^{85} \mathrm{Na}$ pesquisa realizada por Maria das Dores Campos Machado, a centralização no "demônio" era mais intensa nas falas dos entrevistados dos segmentos populares e com menor grau de instrução. Eram os que mais recorriam às práticas de exorcismo (Machado, 1996, p. 201). 
na Igreja Universal do Reino de Deus, de 1977, e a Igreja Internacional da Graça de Deus, de 1980, os principais exemplos.

Como observa Maria das Dores Campos Machado, qualquer comportamento que se aproxime das formas tradicionais de religiosidade, isto é, ligados à cultura brasileira e católica, tais como o sincretismo, adoração a santos e devoção à Maria, são veementemente condenados pelo pentecostalismo. Para se proteger das "forças malignas", prega-se a observância de rígidas regras como as ligadas ao vestuário, a proibição do uso de bebidas e cigarros e das práticas sexuais fora do casamento e é mantido um rígido controle da comunidade (Machado, 1996, p. 83). Que objetiva não só a busca da perfeição cristã, como distinção com o católico e busca evangelizá-lo a partir do próprio exemplo.

Falando especificamente da relação desenvolvida dos protestantes brasileiros com a educação, pode-se afirmar que a prática religiosa e educativa praticamente se confundia para os primeiros missionários que aqui chegaram. Percebiam-se enquanto propagadores de uma nova fé cristã e as escolas que construíam geralmente eram uma das primeiras e mais importantes obras de suas missões. Uma vez que, uma sociedade de analfabetos não condizia com a atividade dos conversos que precisariam ser capazes de ler a Bíblia e alguma literatura religiosa. Mais ainda, a educação era vista como decisiva para uma visão de mundo:

Para a tradição do protestantismo americano, religião, democracia política, liberdade individual e responsabilidade são concebidas como parte de um todo, que está envolvido por uma inflexível fé na educação. (Willems, 1967 apud Ramalho, 1976, p. 70).

Por isso, também acreditavam na educação enquanto principal propulsora de mobilidade social. Tal sentimento era mais comum entre os batistas, presbiterianos e metodistas. Dessa forma, constituiriam a "civilização cristã", a "realização do Reino de Deus na Terra". Apesar de na prática ter sido muito difícil para um grupo minoritário liderado por estrangeiros e patrocinados por eles a encampar tais iniciativas. No entanto, soma-se a essa concepção de sociedade que sustentavam, a crença que a construção de escolas boas, eficientes, bem organizadas, com instalações modernas seria muito considerada pelas elites que matriculariam seus filhos ali e passariam a respeitar tais denominações.

(...) é justamente no campo da educação que o evangelho produz os seus frutos seletos e superiores, homens preparados para falar com o poder à consciência 
nacional (Crabtree, História dos Batistas do Brasil, 1962 apud Ramalho, 1976, p. 69).

Como acreditavam na salvação individual, a única maneira de transformar a sociedade seria pela transformação de cada ser humano, essa seria a ação política possível e desejável (Ramalho, 1976, p. 63). Para daí, por meio dos colégios, formarem uma elite com os valores evangélicos capaz de influir ativamente na sociedade. Mesmo que não se convertessem ao protestantismo, mais tarde, quando ocupassem cargos importantes, levariam consigo os valores protestantes, contribuindo para a sua expansão. Isso, em grande medida, foi atingido. Alguns trechos redigidos pelo missionário que fundou e foi o primeiro diretor do Colégio Batista do Rio de Janeiro são interessantes para perceber tais objetivos:

o Evangelho tem uma mensagem; os Baptistas têm uma mensagem educacional para o mundo. A razão é que eles têm várias doutrinas distintivas. Elles seguem as Escripturas como a única regra de fé e pratica, e creem no progresso social, mediante a regeneração individual; na democracia pura, na liberdade de consciência; na separação entre o Estado e a Igreja; na evangelização do mundo todo. Sua mensagem educacional toma o seu caráter, desta crença fundamental. (...) o modo de levar esta mensagem educacional evangélica ao mundo é por incorporá-lo concretamente em alguns collegios. (...) um número razoável de bons collegios evangélicos pode fazer um serviço incalculável e atingir com sua influência todo o ambiente educacional nestes paizes latino-americanos (Shepard, 1929, apud Ramalho, 1976, p. 75).

Os colégios das denominações históricas pareciam condizer com os novos anseios modernos. E como ainda havia pouca regulamentação, principalmente no início do século XX, tinha-se espaço para novos experimentos pedagógicos e possibilidades de aplicação de diferentes práticas de ensino. Tais escolas iam surgindo na medida em que havia uma confluência de fatores positivos para tal investimento: quando começa a haver pessoal capacitado, recursos econômicos provindo das igrejas originárias que mandaram suas missões, discriminações políticas e religiosas, necessidade de novas profissões, surgimento de pequenas indústrias, crescimento do comércio externo etc. (Ramalho, 1976, p. 74). Apesar de geralmente oferecerem o primário, o maior investimento foi no ensino secundário. Dado que recebia os filhos das classes média e alta, o que era uma boa oportunidade de convertê-los ou colocá-los em contato com a "cultura evangélica", por conseguinte, norteamericana e passar a exercer influência em camadas sociais que detinham algum poder político. Isso, é claro, não sem que houvesse esforço da Igreja Católica em continuar a manter seu antigo monopólio. Para os filhos dos protestantes havia 
programas de bolsa de estudo. Em menos de 50 anos, todos os grandes centros do país foram cobertos por colégios protestantes.

As missões conflitavam na maneira de realizar tal tarefa: afirmavam a liberdade de crença, ao mesmo tempo em que valorizavam o "ardor evangelístico" para a propagação de sua fé. Dependendo da denominação, tende-se para um lado ou para outro, principalmente no que tange à condução dos colégios. O fato é que, conforme foram se abrindo para os não-protestantes, deixavam cada vez mais de lado a veia evangelizadora (Ramalho, 1976, p. 77), apesar do grande sucesso que obtinham. A elite brasileira estava menos interessada no protestantismo enquanto religião e mais na educação que ofereciam (Mendonça, 1990, p. 74). Viam, segundo Mendonça, o sistema religioso como corolário do sistema educacional.

A prática educativa presente no Brasil nesse período era considerada pelos educadores norte-americanos que vinham com as missões autoritária e vertical, como uma prática que não estimulava a participação crítica dos alunos durante as aulas. Achavam que pedagogia valorizava a memorização e era monótona. A ênfase dada era nas línguas, na literatura e na história em detrimento das ciências físicas e naturais que eram apresentadas quase sem uso de laboratórios e experimentação, o que era algo negativo para eles. Ainda na visão dos missionários norte-americanos, a influência europeia, principalmente francesa, dos programas não os aproximava da realidade brasileira. E o número de matérias era visto como excessivo e pouco se relacionavam umas com as outras. Acreditavam que não se dava tanta importância à formação de professores. Outros pontos negativos eram que a coeducação não era comum, a educação tinha pouco sentido prático e o secundário era elitista, já que os trabalhos industriais e manuais eram desvalorizados. Por fim, não se dava tanta importância à educação física.

Um colégio presbiteriano ${ }^{86}$ em 1890 foi utilizado como escola padrão de ensino primário e normal pelo governo de São Paulo para as suas escolas públicas estaduais. Isso se deu por meio da incorporação na secretaria de Horace Lane, então

\footnotetext{
${ }^{86} \mathrm{O}$ Mackenzie, por exemplo, atendia no seu início alunos impossibilitados de frequentar as escolas públicas por preconceito político ou religioso: pais abolicionistas e/ou republicanos e/ou ainda protestantes. Esta escola garantia desde o início a liberdade social, religiosa e política de seus alunos e tinha no seu regimento que não se faria distinção dos alunos quanto a sua raça. Possuía educação evangélica aberta a todas as religiões.
} 
diretor do colégio, Marcia Bown, que dirigia a escola Normal e outras quatro professoras, dando origem ao chamado "grupo escolar" (Ramalho, 1976, 1976, p. 87). Outras denominações que tiveram suas escolas destacadas e influenciaram em muito a vida das elites nas localidades que se instalaram foram os Batistas ${ }^{87}$ e os Metodistas. Essa última denominação realizou em 1953 em um de seus colégios cursos de aperfeiçoamento para professores do Instituto Nacional de Estudos Pedagógicos, atual Instituto Nacional de Estudos e Pesquisas Educacionais Anísio Teixeira (INEP). Fernando Azevedo é um dos que nota a importância de tais escolas não só para a mudança dos métodos, como também para a intensificação do ensino, enfatizando inclusive a difusão do ensino popular por meio das escolas dominicais (Azevedo, 1963 apud Ramalho, 1976).

Para Ramalho (1976), a aceitação, ou pelo menos tolerância em relação à expansão de tais colégios, se deu porque não se constituíram enquanto ameaça para o que fundamentava a sociedade brasileira. Ela mesma, ao longo do tempo, ia reafirmando os princípios liberais tão caros a tais colégios e às denominações que faziam parte. Ao mesmo tempo, a Igreja Católica via tais grupos religiosos como minorias, apesar de nunca deixar de criticá-los. Uma vez que, os protestantes em geral, como visto, eram mais abertos à educação sexual, à valorização da mulher e à Democracia liberal, aspectos ligados à Modernidade, na visão católica da época, contrários à doutrina de Cristo. E, por último, defendiam, na visão dos católicos, a hegemonia pró-Estados Unidos, que contrariava os interesses nacionais (Azzi, 2008, p. 154). Ao passo que, como observa Antônio Gouvêa Mendonça (1990), gradualmente os programas educacionais foram perdendo espaço e a segunda estratégia, conversionista, foi ganhando mais apoio.

Acreditava-se que a leitura da Bíblia conduziria ao desenvolvimento pessoal e social, daí uma de suas ações ser a própria distribuição do livro sagrado. As Igrejas Presbiterianas foram as que mais se expandiram no século XIX. As metodistas e as batistas tiveram um crescimento inicial lento, muito por terem se instalado em cidades de ampla influência católica. A primeira canalizou a maior parte de seus

\footnotetext{
${ }^{87}$ As aulas de "cultura religiosa" eram dadas em cursos avulsos, acreditavam respeitar a liberdade de consciência, mas buscavam inculcar os princípios religiosos que levariam a uma "boa moral de uma vida digna, útil e patriótica". Tinham movimentos intensivos de educação popular para quem não pudesse fazer os cursos regulares (Ramalho, 1976).
} 
investimentos para as escolas, e como a própria denominação metodista reconheceu, "esqueceu-se" de evangelizar. E a segunda ao contrário, por meio do sucesso de seus colégios, investiu na construção de mais e mais igrejas, o que levou a um grande crescimento durante o século XX. Enquanto as elites eram educadas nas boas escolas protestantes e recebiam as influências do pragmatismo capitalista protestante e uma outra parte também pelas escolas católicas, os pobres eram objeto de evangelização direta e dependiam exclusivamente da escola pública.

\section{4}

\section{Continuidades nas disputas}

Durante a Ditadura Civil-Militar, a disciplina de Ensino Religioso foi inserida pela primeira vez no ensino primário e médio e a LDB de 1971 obrigou o ensino de Moral e Cívica que reunia nessa época a doutrina de segurança nacional, conforme se concebia pela Escola Superior de Guerra e o catolicismo nesse momento conservador, quem a normatizou inclusive foi um arcebispo, Luciano José Cabral Duarte, trazendo à tona a ideia de "religião natural" que levaria ao conhecimento de Deus pela razão $\left(\right.$ Cunha, 2009) ${ }^{88}$. Esse foi um período de acirramento do enfoque privilegiado para o ensino superior e as elites, em detrimento da crescente demanda educacional. Foi marcante nesse período a expansão do ensino privado, a institucionalização do ensino profissionalizante, o tecnicismo pedagógico, o autoritarismo e forte centralização, além da desestruturação da formação de professores.

Em 1985, para a Constituinte houve um movimento pela educação pública laica que levou uma emenda popular feita por sindicatos de professores e instituições culturais. O Ensino Religioso também foi anexado em diferentes emendas encaminhadas por diferentes correntes políticas. A CNBB teve papel fundamental na aprovação da disciplina enquanto facultativa a ser ofertada nos horários regulares das escolas públicas de Ensino Fundamental. De outro lado, a Igreja Católica atuava também como no exemplo trazido por Maria Luiza Marcílio, relatada por um secretário de educação de São Paulo entre 1984 e 1986:

havia uma demanda muito grande por ensino médio na zona leste. O Padre Ticão era radical, não marcava audiência. Ele pegava a comunidade, botava no ônibus, criança, mulher, todos, e ia pra secretaria; entrava na secretaria cantando hinos religiosos. E

\footnotetext{
${ }^{88}$ Tal decreto só foi revogado em 1993.
} 
assim, nós o atendíamos. Não havia ensino médio na zona leste. O Padre Ticão chegou lá e disse: 'Professor Renato, o senhor tem de abrir as escolas à noite. $2^{\circ}$ grau à noite'. $\mathrm{E}$ aquilo foi uma guerra com as diretoras das escolas. Mas nós fizemos. E passou a haver ensino médio à noite, por essa pressão da comunidade, via padre Ticão (Marcílio, 2005, p. 124).

A Constituição de 1988 não utiliza o termo "laico" em si mesmo para qualificar o Estado, fala em sua neutralidade religiosa. Além de garantir a liberdade de culto e de crença. Em contrapartida, legisla sobre assistência hospitalar religiosa e o Ensino Religioso facultativo nas escolas públicas, dispõe sobre colaborações que podem ocorrer entre Estado e Igrejas em ações de interesse público, dá imunidade tributária a qualquer templo e abre a possibilidade de utilização de recursos públicos também para as escolas confessionais ${ }^{89}$.

Ao longo da década de 1990 alterou-se a taxa de analfabetismo e o nível e escolarização da população adulta brasileira. A última Lei de Diretrizes e Bases da Educação Nacional de 1996, pautou-se na concepção dos direitos fundamentais de educação de qualidade para todos. Tornaram-se objetivos da educação o pleno desenvolvimento do educando, o preparo para o exercício da cidadania e a sua qualificação para o trabalho (Marcílio, 2005). Além disso, a busca pelo pluralismo de ideias e concepções pedagógicas, o apreço à tolerância, o respeito às diversidades, a gratuidade e garantia do padrão de qualidade (idem, p. 432). Como na Constituição, também não há uma menção explicita ao termo laicidade.

Durante a discussão da última LDB, aprovada em 1996, mais uma vez o debate foi acirrado e diversos atores tiveram papel ativo, entre religiosos e não-religiosos. A CNNB foi um deles. O texto aprovado falava em Ensino Religioso "sem ônus para os cofres públicos" e previa duas formas possíveis: o confessional, de acordo com a opção religiosa do aluno e o interconfessional, resultante de um acordo entre as diversas instituições religiosas. Nesse momento, criou-se o Fórum Nacional

\footnotetext{
${ }^{89}$ Em seu artigo 213 que diz: "Os recursos públicos serão destinados às escolas públicas, podendo ser dirigidos a escolas comunitárias, confessionais ou filantrópicas, definidas em lei, que: (EC no 85/2015) I - comprovem finalidade não-lucrativa e apliquem seus excedentes financeiros em educação; (...) § 1o Os recursos de que trata este artigo poderão ser destinados a bolsas de estudo para o Ensino Fundamental e médio, na forma da lei, para os que demonstrarem insuficiência de recursos, quando houver falta de vagas e cursos regulares da rede pública na localidade da residência do educando, ficando o Poder Público obrigado a investir prioritariamente na expansão de sua rede na localidade. (...)" (CF, 1988, p. 125). A título de exemplo, o financiamento de escolas confessionais também ocorre na França, como citado no capítulo um, e no Canadá.
} 
Permanente do Ensino Religioso (FONAPER) $)^{90}$ que defende o interconfessionalismo e exerceu pressão junto aos governos estaduais e municipais para que efetivassem o Ensino Religioso em seus sistemas educativos, além de realizar concursos públicos para docentes. Visto que mesmo após anos da aprovação da lei a disciplina de Ensino Religioso quase não era oferecida.

Em 1997, segundo Roseli Fishmann (2006) a CNBB divulgou um documento com o que acreditava ser o "ideal” para o Ensino Religioso, a iminente visita do então Papa João Paulo II também exerceu pressão. Assim foi feito, o Congresso aprovou seis meses depois após a promulgação da LDB pelo Executivo, a seguinte mudança ${ }^{91}$ : embora continuasse oferta obrigatória e demanda facultativa, o Ensino Religioso passou a ser compreendido como "integrante da formação básica do cidadão" (Cunha, 2013, p. 76). Na prática ficou a critério de cada estado definir o conteúdo da disciplina, se confessional ou interconfissional e os recursos públicos passaram poder ser utilizados para custear a carreira de docente dessa disciplina.

\section{5}

\section{As disputas por diferentes projetos educacionais}

Um olhar em perspectiva histórica e sociológica nos ajuda a compreender parte da complexidade da relação entre escola pública e religião dando conta de um processo que se constrói não de forma linear, mas por meio da interposição de diferentes atores, lugares e tempos. Assim, observamos que num primeiro momento de hegemonia católica havia grande interesse dessa instituição na educação a reboque do tradicional monopólio da atividade educativa pelos jesuítas iniciado praticamente no nascedouro do que viria a se tornar o Brasil. Isso, de um lado, por meio da expansão das escolas confessionais católicas destinadas à elite e de outro, na medida em que o ensino público começa a ganhar destaque, na defesa do Ensino Religioso. São dois caminhos que confirmam a estratégia institucional da Igreja Católica, e é interessante porque é por esse viés que tal religião atua, em influenciar a vida política brasileira durante toda a primeira metade do século $\mathrm{XX}$. Em contrapartida, a atuação das igrejas protestantes históricas e principalmente as

\footnotetext{
${ }^{90}$ Originou-se do Grupo de Reflexão do Ensino Religioso (GRER) da própria CNBB (Cunha, 2013, p. 75).

${ }^{91}$ Por meio do substitutivo apresentado pelo deputado padre Roque Zimermann (PT-PR) que juntou outros dois projetos.
} 
pentecostais e neopentecostais se dará de forma mais direta, individualmente ou por meio de pequenos grupos, algo muito característico da maneira dessas denominações atuarem, o que nos ajudará a compreender a continuidade de suas atuações na esfera educacional contemporaneamente em duas dimensões no capítulo que se segue.

Se ao proclamar a República, a Igreja aceita inicialmente a laicidade do Estado, afinal também ela não estava se beneficiando totalmente do lugar de religião oficial, já que a Coroa intervia na sua atuação em detrimento de Roma, tal aceitação não se dá com o ensino. Laicidade no ensino público é vista como uma afronta à religião católica e aos seus adeptos. Em contrapartida, ela começará a se valer da ideia de "nação católica" e do "caráter nacional do catolicismo no povo", isto é, de enfatizar na marca identitária brasileira o catolicismo para manter sua autoridade no espaço público. Será por meio de sua atuação na sociedade pouco secularizada que a Igreja Católica buscará as credenciais para disputar suas demandas no Estado laico.

A educação escolar aparece como o meio de difusão para os processos de "recatolização", "romanização" ou "reconversão", termos muitas vezes utilizados como sinônimos, da sociedade brasileira. Isto é, torná-la alinhada aos preceitos da hierarquia eclesiástica oficial. Em detrimento de uma prática religiosa católica popular até então muito comum Brasil afora e devedora, em certa medida, do antigo regime do Padroado e de sua escassez de padres até o momento da proclamação da República. Além disso, tal instituição vale-se também de uma diversidade religiosa ainda pouco aparente em fins do século XIX e início do XX e não economizará esforços para manter os estereótipos criminalizantes ligados às religiões afrobrasileiras e espíritas e também acusar os primeiros protestantes que aqui chegam de heréticos.

O primeiro marco para o início do reconhecimento da diversidade religiosa brasileira se deu ainda no Império por conta da chegada dos ingleses e posteriormente outros imigrantes protestantes. Algo que só irá se consolidar muito tempo depois, na Constituição de 1988. O pensamento positivista gestado nesse período inicial e muito presente nos primeiros anos republicanos funcionou como um anteparo à influência católica no Estado nesse curto espaço de tempo. Nota-se, no entanto, que a virada da Revolução de 1930 que colocou Getúlio Vargas na 
presidência é outro momento importante para a retomada do poderio católico no espaço público. A laicidade, apesar de garantida constitucionalmente, não se materializou aí enquanto um valor a ser defendido. Ou melhor, teve nesse período uma acepção diferente a do momento imediatamente anterior. Vargas, entretanto, atua de maneira parcimoniosa em relação à Igreja Católica, assim lhe concede alguns favores como a reinserção do Ensino Religioso nas escolas públicas, um dos seus primeiros atos enquanto presidente, ao mesmo tempo em que abre espaço para a expansão da rede de colégios protestantes, a essa altura muito bem quistos por uma elite liberal que queria se modernizar.

Pode-se dizer que, nesse ínterim entre o fim da Primeira República até o golpe de 1964, passando aí por diferentes momentos ora democrático, ora autoritário, o campo educacional é fortemente disputado. Os Pioneiros da Escola Nova com a sua defesa da escola pública de modelo único gratuita e obrigatória, da função educativa do Estado, da laicidade no ensino e da coeducação inauguram um novo olhar diante do problema educacional e a sua inserção na agenda pública pela primeira vez enquanto um direito de todos e não privilégio de alguns. Buscam exercer sua influência nas diferentes instâncias de poder como o Conselho Nacional de Educação, o Ministério da Educação, a universidade e a imprensa. Desse modo, encontram nos intelectuais católicos comprometidos à época, com um modelo dual de sociedade, que visava chegar numa sociedade cristã, um grande contraponto. Eram vastas as frentes de atuação católica do período: por via das suas escolas, dos seus intelectuais e instituições, publicações na imprensa, incentivo aos professores católicos que fizessem concurso para atuar no ensino público, pela promoção da vida familiar e pela defesa do Ensino Religioso na escola pública.

Concomitantemente, em menor escala, a presença das escolas protestantes contrasta com o modelo educacional católico, o primeiro também para as elites e comprometido com a busca da formação do "Reino de Deus na Terra". Entre os protestantes tinha-se uma visão do Brasil bastante etnocêntrica, como um lugar "atrasado", por conta de sua histórica relação com o catolicismo. Algo que se justificava na defesa do cumprimento do "destino manifesto". Visavam construir uma sociedade basicamente nos moldes norte-americanos, com valores democráticos, liberdades individuais, responsabilidade individual pela própria 
salvação e separação entre Estado e Igreja. A associação com a sociedade norteamericana para os católicos era contra os interesses nacionais. Outro momento de influência protestante dessa vez atuando diretamente no Estado se deu em São Paulo quando professores presbiterianos foram chamados para padronizar o ensino normal e primário no final do século XIX tendo como base a sua escola confessional onde trabalhavam.

A questão racial para a Igreja Católica do período subsumia à ideia de sincretismo de uma maneira parecida com a clássica discussão da miscigenação brasileira. Isso ao evitar conflitos em favor de uma aparente conciliação como no mito da democracia racial. O paradigma do sincretismo, visto como integrador das diversidades étnicas e culturais na ótica católica, era uma maneira de evitar tais questões e ressaltar a primazia da identidade católica enquanto a identidade dos brasileiros, uma vez que mesmo no sincretismo o status de religião era dado a tal instituição. Isso desde a omissão em relação à escravidão e a contribuição para que se perpetuasse até posteriormente na assistência aos libertos, o que começa a mudar nos anos 1950 apenas chegando mais recentemente na atuação da Pastoral Afrobrasileira apoiada pela CNBB e a intepretação da Nossa Senhora Aparecida como "Senhora Quilombola", por exemplo (Silva, 2011) $)^{92}$. Os grupos protestantes também se omitiram em relação ao sistema escravagista. Há, no entanto, a menção em um dos exemplos de escolas confessionais pesquisadas como vimos, a presbiteriana, que já no século XIX constava do seu regimento a não distinção dos alunos quanto a sua raça. No geral, como chama atenção Patrícia Birman (2011), diferente da histórica associação de parte do movimento negro a partir das identidades dos cultos afro-brasileiros, os evangélicos esvaziam as identidades afrobrasileiras $^{93}$. Isso para rejeitar o lugar hierárquico com que tais identidades são geralmente dispostas na sociedade. Seu enfoque então é o da igualdade e por isso,

\footnotetext{
${ }^{92}$ Como Vagner Gonçalves da Silva (idem) explica, o diálogo entre o catolicismo e o Candomblé geralmente se dá pela inserção de elementos africanos nos rituais católicos numa perspectiva de "enculturação da liturgia", o exemplo mais claro disso trazido pelo autor é a "missa afro". ${ }^{93} \mathrm{Um}$ exemplo em que isso fica muito claro é o trazido por Morgane Laure Reina (2017) relatado por uma de suas entrevistadas: uma jovem evangélica resolveu parar de alisar o cabelo e começou a trançá-los numa maneira de reivindicar a sua identidade negra. Durante o culto foi exposta diretamente pelo pastor em público que se justificou dizendo que ela havia "cedido ao demônio" (idem, p. 261).
} 
acabam diabolizando a diferença, produtora de desigualdades ${ }^{94}$. Assim, o tratamento igualitário se dará pela conversão, o que, de acordo com Birman, envolve a ruptura com os entes diabólicos ${ }^{95}$. Apesar dessa visão geral, tem surgido um debate que vai de encontro a essa percepção feito por diferentes movimentos negros evangélicos independentes desde a década de 1970 no Brasil $^{96}$.

Com isso, vamos entendendo que a relação entre religião e educação no Brasil não é nova e mais ainda, quase em nenhum período se deu de maneira lisa, sem disputas. Então, o que há de novo nessa relação na contemporaneidade? Essa é uma pergunta que será respondida no capítulo seguinte, sem pretensão de esgota-la é claro. Isso com a ajuda da observação de dois lugares em que tais conflitos se manifestam. A consolidação da diversidade religiosa brasileira, especialmente ao que tange à entrada protestante, primeiramente dos históricos e mais recentemente dos pentecostais e neopentecostais perturba a naturalizada acomodação entre Igreja Católica e Estado colocando em xeque a até então quase inquestionável laicidade estatal. Com isso, compreendo o período atual como um momento de inflexão, tal transição religiosa denota no mínimo novos atores no espaço público, novos comportamentos dos antigos e uma configuração mais complexa no ambiente escolar público brasileiro.

A secularização e a Modernidade definitivamente não são processos sequenciados. A modernização brasileira se deu, entre outras coisas, sem que a influência da Igreja Católica tivesse cessado, o que em grande medida levou à construção da ideia de laicidade a partir também da contribuição do próprio clero católico. Como vimos

\footnotetext{
${ }^{94}$ Numa perspectiva, por exemplo, da "irmandade cristã" como nas frases trazidas por Branchini (2013) "somos todos filhos de Deus" ou "Deus não se importa com a cor da pele".

${ }^{95}$ Já no Censo de 2000, Antônio Flávio Pierucci (2006) observava que, apesar de os negros serem maioria nas religiões afro-brasileiras em relação ao conjunto geral da população, isto é, proporcionalmente.“(...) se, compreensivelmente, ainda não é maior no Brasil de hoje o número de negros evangélicos do que o número de negros católicos, longe disso, é fato que há muito mais negros evangélicos [em termos absolutos] do que negros espíritas, do que negros umbandistas, do que negros no Candomblé, do que negros nas outras religiões e negros e declarando sem religião" (idem, p. 27), o que, como observa Vagner Gonçalves da Silva (2011), para algumas lideranças evangélicas as políticas públicas que envolvam etnicidade poderia ter essas igrejas como parceiras preferenciais.

${ }^{96}$ Alguns dos grupos são o Movimento Negro Evangélico (MNE); Associação Nacional do Movimento Negro Evangélico (MONEBA) (Reina, 2017); pastoral da Negritude do Conselho Latino americano de Igrejas (CLAI); Sociedade Cultural Missões Quilombo; Ação e Reflexão Martin Luther King; Aliança de Negras e Negros Evangélicos do Brasil (ANNEB) (Branchini, 2013). Também pela via da música, o black music gospel (Pinheiro, 2007 apud Reina, 2017) e o rap gospel (Novaes, 2012).
} 
no capítulo anterior, a laicidade é instituída no Brasil a partir da regulação dos direitos e deveres da Igreja Católica e não da regulação dos direitos e deveres de todas as outras religiões. Sua retirada do Estado contribuiu inclusive para que as esferas se diferenciassem, a começar pela própria sociedade civil. Se a Igreja Católica se manteve por algum tempo contra tudo o que representava esse novo momento, o individualismo, por exemplo, os intelectuais da Escola Nova e as Igrejas protestantes históricas com suas escolas confessionais pressionavam para que o Brasil entrasse nos trilhos da modernização. Também essa instituição precisou se rever com o seu arggiomento no Vaticano II mais à frente na década de 1960.

Como Weber já havia alertado, o processo de racionalização crescente atinge as mais diferentes esferas, o que não quer dizer que elas não possam concorrer entre si. Já a autonomização é algo que no período estudado ainda estava em jogo, principalmente da esfera educacional, percebida pelos católicos muitas vezes diretamente como educação cristã, religiosa e moral ou as englobando e, pelos protestantes, como tendo uma função conversionista, a sua prática religiosa era uma prática educativa. Na sociedade brasileira, a influência das religiões não diminuiu, modificou-se, isto é, experimentou um processo de secularização que implicou menos no declínio e mais na mudança do lugar institucional das religiões. Logo, torna-se oportuno compreender a laicidade enquanto um valor em disputa pelos próprios indivíduos na sua ação, não apenas como um dispositivo jurídico resultado de um consenso constitucional que separa Estado e religião. No mundo da vida, no entanto, um e outro se constroem mutuamente.

A crise moral, o desmoronamento das instituições vigentes e desorientação das consciências individuais, muitas vezes interpretada pelas igrejas como uma crise também da família tradicional pode ser uma das interpretações possíveis da crise da modernidade. Um mundo cada vez mais complexo e cheio de incertezas pode ter na religião uma boa lente. No período estudado, o catolicismo aparecia como a âncora para a garantia da ordem social e moral, para a estabilidade e disciplina. O protestantismo em suas variadas vertentes colocava-se como uma nova forma de lidar com esse "mundo novo", pautado no mérito, nas relações impessoais de trabalho e no individualismo. Desse modo, apresentam-se como apoio e fornecem 
recursos materiais e simbólicos para dar sentido à vida, como atestou Regina Novaes (2017) e tantos outros, e enfrentar os problemas infelizmente presentes nas camadas populares brasileiras por conta especialmente das desigualdades sociais.

Daí a escolha de no próximo capítulo ampliar o olhar para controvérsias que se dão em torno não só das religiosidades no ambiente escolar, também no campo da moralidade, algo que já vinha sendo disputado anteriormente e que ganha novos tons. Uma vez que, de diferentes formas, moral e religião são mais ou menos correlacionadas numa justificativa educacional. Durante o período em que vigorou o Regime Militar nota-se uma aliança entre Igreja Católica e Estado para manter nas escolas públicas as disciplinas de Ensino Religioso e de Moral e Cívica, essa última que havia também figurado no currículo anteriormente na Ditadura do Estado Novo. O período autoritário que compreende 1964 até a redemocratização é também quando ocorre o boom dos pentecostais nas favelas e periferias urbanas e a consolidação das cidades como o espaço de moradia para a maioria da população brasileira que, pela primeira vez, deixava de habitar maciçamente o campo. Além disso, esse é um momento de acirramento das atuações não hegemônicas do laicato católico e também entre o próprio clero, mais conectados com as questões sociais brasileiras, a começar pelo analfabetismo estrutural.

Em resumo, são contrapostos diferentes projetos educacionais que vislumbram diferentes sociedades possíveis e vice e versa, a tradicional e/ou a moderna. A educação confessional católica inspirada no modelo europeu, mais academicista, erudito e autoritário conecta-se às velhas elites rurais que fundamentam hierarquias e obediências, à família patriarcal, aos "bons costumes" e à ordem social; a educação confessional protestante, mais ligada a um conhecimento cientifico prático e aberta por exemplo, à educação sexual, à igualdade de oportunidades educacionais entre meninas e meninos, à democracia liberal; a Escola Nova, mais próxima do segundo exemplo, destaca-se pela defesa da escola pública de modelo único para todos, adequando o sistema educativo aos ventos democráticos $\mathrm{e}$ republicanos que vinham acompanhados de profundas mudanças na ordem econômica por meio da industrialização e urbanização da sociedade e também as impulsionavam. Até aí, a via de acesso para o tipo de sociedade que se disputava era a educação escolar. Esse não era o caso dos pentecostais que ao focarem nas 
suas doutrinas não deram o mesmo valor à construção de escolas como os protestantes históricos, preferiram a conversão direta tendo como público alvo inicial os mais pobres das cidades. Mesmo essas denominações, por meio de seus missionários proselitistas, passaram a inculcar a ideia de "fé na educação" entre os seus novos fiéis. Não se pode deixar esquecer, a prática religiosa evangélica é profundamente ligada à leitura e interpretação da Bíblia e de outros livros religiosos, daí o incentivo à escolarização, a começar pelo processo de alfabetização não tão comum ainda nesse período entre as camadas populares. Uma vez que a educação escolar pública ainda não era extensamente presente no território nacional. Como também a partir da perspectiva ascética da salvação que tinha no sucesso uma das manifestações da escolha de Deus. Estudar era um caminho para a mobilidade social.

Verifica-se historicamente um projeto para as camadas populares e outro para as camadas médias e altas da sociedade brasileira. Em um primeiro momento, era destinada à elite, geralmente branca, uma educação ilustrada que visava ao ensino superior e que depois foi longamente priorizada ao longo do monopólio católico educacional. Aos mais pobres, indígenas, negros e mais à frente, colonos, a educação era meramente religiosa. Seguiram-se a contratação de preceptores, as aulas-régias na maioria das vezes para quem pudesse pagar, os mais pobres recebiam uma educação oral e o catecismo. As meninas da elite começaram a ser educadas muito tempo depois, passando inicialmente a ter contato com uma educação meramente religiosa. Em diferentes períodos os escravos e seus descendentes foram proibidos de frequentar a escola, não eram nem reconhecidos, quanto mais sua cultura e sua religião encoberta no sincretismo hierárquico. $\mathrm{Ou}$ então eram incentivados nas escolas protestantes a receber o Ensino Religioso como forma de regenerar-se.

Por grandes momentos estagnou-se, mesmo quando o Estado brasileiro começou de fato a pensar as políticas educacionais: o secundário geralmente pago era frequentado pela elite e o primário era destinado ao povo. Parte responsável por essa divisão foram as próprias religiões católica e protestantes que passaram a se dedicar a abrir escolas confessionais por todo o Brasil. Além disso, a própria Igreja Católica tentou inibir enquanto pôde o investimento em um ensino público gratuito 
para todos justificando-se na "liberdade de ensino", e alegando que o Estado teria o monopólio da tarefa educacional se assim não fosse. Como também condenando qualquer escola que não fosse católica, pois teria um "ensino ateu”. Essa instituição religiosa cedeu à política de incentivo ao ensino público apenas quando houve a garantia de inserção do Ensino Religioso mesmo que facultativo. Não sem criticar o ensino profissionalizante, mais à frente incentivado durantes os dois regimes autoritários mais recentes, como uma maneira de laicizar o ensino.

As escolas católicas e protestantes tinham um objetivo muito claro que era a formação das elites dirigentes. Nesses casos, os valores religiosos estavam geralmente presentes, mas não se deixava de lado a formação do que se considerava uma boa educação, seja nos moldes europeus ou norte-americanos. Aos mais pobres e/ou negros era ofertada à conversão direta dos pentecostais e quando muito a escola pública, na medida em que a sua rede se amplia tendo como uma disciplina facultativa o Ensino Religioso, na prática quase sempre de confissão católica. $\mathrm{O}$ incômodo com os escolanovistas era tal, visto que seu projeto de educação era único, para todos.

Não é exagero dizer que se apostava nas religiões especialmente para as camadas populares e minorias como um instrumento civilizador, por vezes visto como uma maneira de manter a antiga ordem social vigente e segurar as mudanças que se avizinhavam, especialmente no que tange à autonomização dos indivíduos. Tal incentivo era interessante para influenciar condutas e comportamentos, daí as suas acepções morais, de valores e atitudes. Desse modo, essa era a defesa mínima para tal grupo social. Já entre a elite a inspiração poderia até ser religiosa, mas isso não impedia o acesso a uma educação ampla e de qualidade, justificada na ideia de que esses seriam os futuros dirigentes. No fundo, os diferentes grupos disputavam o projeto de sociedade que queriam construir de acordo com o que acreditavam ser o melhor caminho.

Contemporaneamente, as escolas confessionais têm perdido cada vez mais força para as escolas privadas ligadas estritamente ao mercado, o que já se iniciava no momento da discussão da primeira LDB quando se juntaram ao grupo católico os donos das escolas particulares. De lá para cá, a força política desse grupo cresceu enormemente, uma vez que a sua rede se expandiu em todo o território nacional, 
principalmente a partir da Ditadura de 1964, o que também pode ser um dos efeitos da diminuição da transmissão da religião de herança e do aumento dos "sem religião".

As escolas confessionais eram estratégicas na formação de uma sociedade com valores católicos ou protestantes, na possível influência que as elites poderiam exercer no espaço público munidos de tais princípios no futuro. Aí reside a importância em compreender também tais escolas para efeitos deste trabalho. Ao se discutir os diferentes projetos educacionais como no caso da primeira metade do século XX no Brasil ao fim e ao cabo o que se discute é o sentido da escola pública e isso se deu ativamente por toda a sociedade e por uma diversidade cada vez maior de instituições laicas ou religiosas. É o que ocorre também com o debate polêmico do Ensino Religioso que ora vai e ora volta, tem-se mais uma vez a escola pública na ordem do dia. Isso, no seu sentido mais caro, na disputa de significado do que compõe de fato a educação e resgatando a sua concepção "pública". 


\section{A disputa moral e religiosa que ocorre na escola pública contemporânea brasileira}

As disputas sociais que ocorrem para a constituição do que se entende por escola pública, seu currículo, sua finalidade, etc, se dão em diversos níveis observáveis, sendo dois os aqui escolhidos: o do "chão da escola", isto é, do dia a dia de professores, gestores, alunos e famílias; como também no nível da construção de propostas legislativas e resoluções para o currículo. Isso se dá, dependendo do contexto, com mais ou menos distância e influência um do outro.

Partindo-se do princípio de observação das falas de professores em uma escola pública municipal carioca ${ }^{97}$, ainda que de maneira modesta, como também de outras pesquisas empíricas, faremos uma discussão sobre tais situações que envolvem a moralidade e as religiões que adentram o ambiente escolar público no seu cotidiano. Elas nos servirão como pistas para evidenciar as disputas. A outra dimensão de análise trazida, a dos debates que ocorrem mais propriamente no campo político, atualizará o que foi iniciado no capítulo anterior. Veremos em que medida as disputas religiosas e morais adentram as discussões sobre a legislação e as políticas educacionais mais recentes, especialmente em relação ao currículo. Será um panorama sobre uma contemporaneidade múltipla e complexa.

\section{1 O chão da escola: uma escola pública municipal da Zona Sul do Rio de Janeiro e algumas outras pelo Brasil}

O Rio de Janeiro é um dos únicos estados brasileiros em que a maioria dos habitantes já não se declara como católica ${ }^{98}$. 45,8\% da população afirmou-se como católica no último Censo e 29,4\% disse professar alguma das religiões protestantes, sendo que $15,8 \%$ desse total pertence a uma das religiões pentecostais. Esse é um dos estados em que os evangélicos têm importante presença, assim como em todo

\footnotetext{
${ }^{97}$ Numa pesquisa coordenada pelo professor do Departamento de Ciências Sociais da PUC-Rio, Marcelo Burgos que teve o objetivo de compreender a rede de proteção à infância e adolescência a partir da perspectiva da vulnerabilidade escolar materializada em situações de infrequência e evasão escolar. Realizou-se um trabalho de campo em uma escola pública; um Conselho Tutelar; a Promotoria de Infância e Juventude; e também em um CRASS (Centro de Referência Assistência Social). A Rocinha, o recorte territorial do estudo, faz parte da área de abrangência das instituições. ${ }^{98}$ Juntamente com Rondônia, com $47,55 \%$ e Roraima, com $49,14 \%$ da população declarando-se como católica.
} 
o resto da região sudeste (IBGE, 2012). Além disso, destaca-se o número de pessoas sem religião, 15,6\% da população. Dos que se declararam pertencentes às religiões afro-brasileiras, especialmente Umbanda e Candomblé, parte significativa está situada no estado do Rio de Janeiro (idem), 0,9\% de sua população.

Em um survey realizado em 2010 com 323 responsáveis pedagógicos de seis escolas públicas localizadas na mesma região da escola aqui apresentada, a grande maioria deles moradores da Rocinha, chegou-se aos seguintes dados sobre religião: 59,3\% dos responsáveis declarou-se como católicos; seguidos dos evangélicos, 21,1\%; e sem religião, 13\% (Burgos e Rossi, 2014). Chamou-se atenção para a importância da igreja como dimensão central da sociabilidade para tais famílias, $70 \%$ dos católicos a frequentavam pelo menos uma vez por mês e $91 \%$ dos evangélicos frequentavam a igreja pelo menos uma vez por semana. Tais informações ganham mais importância quando se nota o baixo grau de sociabilidade da maioria dos responsáveis entrevistados pela pesquisa apresentada. A média de católicos desse grupo específico é ligeiramente maior do que a média do estado do Rio de Janeiro.

A Escola Municipal Cartola ${ }^{99}$ está localizada na Zona Sul carioca, em um bairro de classe média alta, numa rua residencial. Atende principalmente alunos provenientes das favelas da região, particularmente a Rocinha. Possui um contingente de quase 800 estudantes, todos do Ensino Fundamental, divididos nos turnos matutino e vespertino. Foram entrevistados ${ }^{100} 9$ docentes de diferentes disciplinas: História, Língua Portuguesa, Inglês, Teatro e Matemática ${ }^{101}$, todos atuam no $2^{\circ}$ segmento do Ensino Fundamental, isto é, dão aulas para estudantes com idades entre 11 e 15 anos em média. As perguntas selecionadas para efeito deste trabalho foram as seguintes: "como é a sua relação com os alunos?", "como você percebe a presença da religião na escola?" e, à medida que o tema dos valores aparecia na fala dos

\footnotetext{
${ }^{99}$ Nome da escola fictício.

${ }^{100}$ Aproveito para agradecer enormemente aos colegas estudantes da graduação de Ciências Sociais da PUC-Rio que participaram das entrevistas e das transcrições, são eles: Ana Laura Cannizza, Bruno Delecave, Caroline Bernardoni, Guido Dowsley, Renata Thomaz e Yago Reis e também a Mariana Junqueira, mestranda do Programa de Pós-Graduação em Ciências Sociais da PUC-Rio.

${ }^{101}$ Todos graduados nas disciplinas que ministram, alguns com a formação em nível de pósgraduação. Alguns atuam também no Estado ou na rede particular, outros, apenas no Município. Com idades e tempo de serviço variados. Seis mulheres e três homens.
} 
entrevistados, já que esta não foi uma pergunta prevista anteriormente, questionavase “quais seriam os valores ensinados?".

Apesar de tocarem em diversos assuntos, percebi seis possíveis pontos de análise que serão significativos na medida em que nos aproximam de uma discussão mais ampla entre religião, moralidade e escola. Isto é, funcionarão aqui como disparadores para complexificar a interface proposta. Acionando-se outras pesquisas que corroboram com o encontrado na Cartola ou que tragam novos enfoques. O ponto de partida é a naturalização do catolicismo enquanto parte da cultura; o segundo aspecto, em contrapartida ao primeiro, tem a ver diretamente com as percepções dos professores em relação às mudanças no campo religioso no dia-a-dia com os seus alunos. Sim, eles percebem que a configuração da maioria dos seus educandos atualmente é outra, seja em relação a eles mesmos ou em relação ao passado brasileiro de "nação católica". A terceira categoria são as percepções dos professores em relação especificamente aos seus alunos evangélicos, como os percebem e os diferenciam dos outros e de si mesmos. $\mathrm{O}$ quarto ponto são as suas percepções sobre a intolerância religiosa na escola; o quinto sobre o ensino de valores, de uma moralidade específica defendida por eles como importante. A última categoria se refere à própria opinião dos professores da relação entre religião e escola ou, pelo menos, a maneira que elaboram tal assunto.

\subsection{1}

\section{Dada a "maioria católica brasileira"}

O catolicismo muitas vezes se apresenta como uma "bagagem" para a maioria dos brasileiros, fez e ainda faz parte da nossa formação sociocultural: a maioria dos feriados e festas tem uma origem nessa religião, as interjeições como "ai meu Deus", "ave-Maria", "nossa Senhora" são muito difundidas nas falas das pessoas, independentemente de serem adeptas ou não a alguma religião, inclusive no ambiente da escola pública (Setton e Valente, 2015). Nesse sentido, é de se esperar que haja uma naturalização por parte das pessoas deste assunto, principalmente quando elas fazem parte dos grupos estabelecidos. Desse modo, é "natural" que se associe, por exemplo, como foi o caso da professora Adriana ${ }^{102}$, o seu papel enquanto catequista com o papel de professora do Ensino Fundamental e sua

\footnotetext{
${ }^{102}$ Os nomes dos professores aqui utilizados são fictícios.
} 
transmissão de alguns valores e ensinamentos "de dentro" da religião para os seus alunos da escola municipal Cartola, mas não especificamente da sua, a católica. Destaca-se o "efeito de invisibilidade do catolicismo", como colocado por Emerson Giumbelli (2007). Uma vez que ele ainda se estende à ordem cultural no Brasil. Duas das professoras, fazem essa consideração. A ideia de "maioria católica" aparece para justificar os feriados e as festas. Desse modo, não é à toa que as únicas professoras que declararam espontaneamente a sua religião pertenciam a essa instituição.

Somado a isso, pode-se dizer que o ponto de partida é geralmente o da crença de um Deus, em geral, um Deus cristão. Como aponta André Droogers (1987), uma "religiosidade mínima brasileira" percebida nos meios de comunicação de massa e no cotidiano das pessoas em ambientes seculares. Contemporaneamente, persiste a ideia de um "fundo" religioso de toda brasileira e brasileiro e isso também pode ser percebido na escola. Cláudia às vezes, por exemplo, fala sobre qual o "nosso papel (...) como cristão de um modo geral" em suas conversas com os alunos. Reforçase, dessa maneira, o argumento de Birman (2003), trazido no primeiro capítulo: religião e sociedade se constroem mutuamente, dessa forma, os ambientes são ditos como seculares, mas não podemos pensar de antemão que os indivíduos e a cultura são seculares, apenas que experimentam ventos secularizantes, na expressão de Regina Novaes (2004). Em detrimento da religião institucionalizada, ganha espaço no "chão da escola" uma forte religiosidade entre as pessoas (Setton e Valente, 2015).

\subsection{2}

\section{"Também porque a gente tem é um bom número de alunos evangélicos, né?"}

Sabendo então desse "solo católico", os professores não deixam de perceber as mudanças no campo religioso brasileiro, por meio de seus alunos. Isso se dá em dois aspectos: a maior presença de alunos evangélicos e também daqueles que aparentam ser mais distanciados de qualquer religião. Em geral, eles enxergam parte significativa dos seus alunos como adeptos às denominações protestantes, ou, ao menos, pertencentes a famílias evangélicas. Observou-se ainda que, individualmente, os adolescentes, alunos da Cartola, não cultivam uma religiosidade "no sentido de ter uma fé", como colocou uma das professoras, o que 
ela se ressente. Entretanto, atentou-se que há muitos católicos na Rocinha, apesar da percepção da maioria evangélica, e um ou outro que professa alguma das religiões afro-brasileiras. Além disso, como exposto pelo professor Felipe, em relação a outras regiões como a Baixada Fluminense, essa escola possui uma menor incidência de alunos evangélicos. Uma configuração que tem sido típica do estado do Rio de Janeiro, como vimos no início do capítulo. Ao ser perguntada sobre a sua atuação, uma professora coloca:

não é porque eu sou uma católica, não boto minha religião de jeito nenhum, eles sabem, entendeu? Deus me livre botar pra rezar aqui... (risadas) Nada disso, nem na época da eleição, por causa do Crivella ${ }^{103}$, não comentei nada.

Os alunos evangélicos se destacam mais do que os outros, o que não quer dizer necessariamente que sejam maioria quando, por exemplo, se coteja com os dados do survey trazido no início. O fato de se sobressaírem pode criar esse efeito entre os professores.

Em seu trabalho sobre "ciclos festivos" em escolas públicas no Recife, Maria Edi da Silva (2011) aponta de que forma geralmente aparecem as religiões na escola: os afro-brasileiros tem a imagem vitimizada; os católicos são naturalizados, vistos como hegemônicos e de presença constante; os espíritas são apaziguadores e caridosos geralmente; e, por último, os evangélicos são os novos protagonistas e reivindicam direitos, principalmente argumentando por meio da Bíblia. A despeito disso, são os que mais se fazem presentes no ambiente escolar. Em relação ao Nordeste mais católico ${ }^{104}$, o Rio de Janeiro contrasta uma vez que, por aqui evangélicos e afro-brasileiros podem se encontrar com mais frequência também na escola pública. Embora lá, como colocado, o primeiro grupo religioso já requeira direitos. Já numa escola pública municipal de Santo André, região pertencente ao grande ABC paulista, pesquisada por Gabriela Abuhab Valente (2015), constata-se que havia na escola uma reprodução das hierarquias religiosas: os católicos em primeiro lugar, os evangélicos na sequência e as religiões afro-brasileiras inferiorizadas grande parte das vezes, em detrimento de uma verdade bíblica, letrada e legitimada (idem, p. 54).

\footnotetext{
${ }^{103}$ Prefeito do Rio de Janeiro eleito em 2016, pertencente ao Partido Republicano Brasileiro (PRB), pastor licenciado da IURD.

${ }^{104}$ Apesar da continuada redução do catolicismo em todo o Brasil, o Nordeste brasileiro possui $71,3 \%$ da sua população declarada como católica, perdendo apenas para o sul, com $77,4 \%$, segundo dados do Censo de 2010 do IBGE (IBGE, 2012).
} 
Outra constatação citada por alguns professores da escola municipal Cartola, os alunos se afastam das religiões. Falamos de estudantes adolescentes, com idade entre 11 e 15 anos. É difícil inferir que já apresentem um comportamento mais ligado a experimentações e rupturas em relação à família, como foi observado por Novaes (2004) no caso de jovens entre 15 e 24 anos. Pode significar uma não adesão à instituição ou identidade religiosa, mas um caminho próprio, como apontado por Cecília Loreto Mariz e Maria das Dores do Campo Machado (1998), ao falar da categoria "sem religião" do censo do IBGE. Ao mesmo tempo, torna-se imprescindível relativizar os sentidos do pertencimento religioso: Clara Mafra (2013), a partir da hipótese de Mariz (2012 apud Mafra, 2013), discorre sobre um novo sentido dado à religião por conta da maior influência dos evangélicos entre os brasileiros para ajudar a explicar o aumento dos declarantes "sem religião" no último censo, principalmente entre os jovens. Considerando-se que, para se "ter religião" é preciso "frequentar uma igreja", e isso não está acontecendo, então era melhor se declarar como "sem religião". O sentido do pertencimento é outro, dá-se geralmente entre os protestantes por uma escolha e não por uma herança como é no catolicismo $^{105}$. Nas pistas das autoras, a hipótese é a de que haja um encontro geracional de professores que nasceram e cresceram em um país cuja díade do ser brasileiro e do ser católico era geralmente verdadeira. Para tais alunos, tal relação não se dá mais de uma forma correlata, e o conceito de pertencimento já é outro. Em suma, esta é a contextualização do cenário: uma naturalização do catolicismo, na mesma medida de uma percepção das mudanças no campo religioso brasileiro pelos próprios professores.

\subsection{3}

\section{“Ah, não posso fazer isso porque a minha mãe não deixa, porque a gente vai pra igreja"}

Lidar com os alunos evangélicos para os professores pesquisados da escola municipal Cartola parece algo novo, embora cada um, à sua maneira, possua as suas estratégias. Normalmente, eles são generalistas quando falam desse grupo, o que denota uma dificuldade em conhecer o mundo dos seus alunos, inclusive na sua diversidade religiosa. Geralmente, fala-se em "evangélicos" ou “crentes". Ronaldo

\footnotetext{
${ }^{105}$ Embora já se perceba atualmente um protestantismo e pentecostalismo "de herança".
} 
Almeida (2017) aponta que nos últimos anos o termo "evangélico"106 também está sendo disputado entre aqueles que se autodeclaram assim. Muitas pessoas têm inclusive preferido se denominar como "cristãos", dado o estigma adquirido pela primeira palavra, algo que se percebe também com o termo "crente" (Mendonça, 1990). Uma coisa é notável: os evangélicos são um grupo plural e é contraproducente generalizá-los, uma vez que isso pode revelar preconceitos com relação a esse segmento religioso na sociedade brasileira como um todo. Como no caso da professora Tatiana que, ao falar da visão de seus alunos a partir do protestantismo, chama as religiões dos seus alunos de "crendices".

Os alunos evangélicos são notados pelas falas do tipo "ah, não posso fazer isso porque a minha mãe não deixa, porque a gente vai pra igreja”, por meio de comportamentos, as roupas que utilizam - "saia debaixo do joelho"-, ou por serem mais quietos e disciplinados. Os estudantes evangélicos são percebidos ainda pela associação comum da maioria deles, principalmente os pentecostais, ser mais pobre, afinal precisam de uma maneira de "se agarrar a alguma coisa na vida pra conseguir continuar”, como explanou a professora Flávia. Ela relaciona a maior presença de igrejas na Rocinha à pobreza desse espaço social. Vários autores percebem um maior crescimento do pentecostalismo nas periferias, subúrbios e favelas Brasil afora (Birman, 2011, Neri, 2011; Mafra, 2013), mas como atenta Ricardo Mariano (2011), a pobreza ou a privação social não são os únicos fatores que explicam a expansão dessas denominações especificamente nesse estrato social. Embora o pentecostalismo possa ajudar os fiéis a lidar com a situação econômica nas camadas populares, como colocado por Cecília Loreto Mariz (1991). Isso, especialmente numa estratégia para a criação de motivação, valores ou o desenvolvimento de um estilo de vida, tal adesão não ocorre apenas como "resposta" à situação nessa camada. Chamo atenção para a retomada histórica feita no capítulo anterior, se católicos e posteriormente protestantes históricos escolheram o investimento nas escolas privadas confessionais para a formação de uma elite influenciada pelos seus valores, aos pobres foi ofertada a conversão

\footnotetext{
${ }^{106}$ Assim Ronaldo Almeida sintetiza a categoria "evangélicos": "um segmento religioso formado por pessoas na maioria das vezes honestas e confiáveis nas relações face a face, mas pouco tolerantes com religiões e morais alheias, e cujas lideranças costumam ser percebidas com desconfiança, sendo algumas consideradas ambiciosas e arrivistas (Almeida, 2007, 174). Também criminosas, acrescento, hoje" (Almeida, 2017).
} 
principalmente pelos grupos missionários pentecostais. Nesse sentido, torna-se importante a análise da oferta religiosa em perspectiva.

Comparando a visão que os professores observados por Silva (2011) no Recife possuem em relação aos seus alunos evangélicos e as observadas na escola municipal Cartola no Rio de Janeiro, pode-se dizer que os primeiros veem a escola como um local de fuga para esse grupo de estudantes, como um canal de libertação. Para os professores cariocas observados, os alunos evangélicos são mais disciplinados - comportados e corretos como colocado por Adriana - e isto é visto como algo positivo, já que se contrapõem à ideia de aluno "problema", entendida como o aluno bagunceiro, "favelado". Geralmente, os que dizem não professar nenhuma, são mais bagunceiros. Uma possível explicação para a diferença nas duas escolas pode ser a passagem pelo ritual do batismo pelos alunos mais velhos, já no segundo segmento do Ensino Fundamental ${ }^{107}$, como é o caso da observação feita no Rio. A professora Cláudia notou as diferenças do batismo evangélico. Maria Edi Silva (2011) esclarece que há uma grande mudança de comportamento entre os alunos batizados e dos não batizados, quando ocorre tal ritual, geralmente aos 12 anos, as cobranças aumentam e os comportamentos se modificam. Aí se dá a passagem para o pertencimento oficial à religião. É como se um - na escola de primeiro segmento ${ }^{108}$ observada por Silva no Recife - fosse o momento anterior do outro - na escola municipal Cartola no Rio de Janeiro. No mais, as percepções giram em torno dos comportamentos, das condutas, dos estilos de vida e da condição social e o lugar onde moram tais alunos.

As estratégias utilizadas para lidar com eles são as mais diversas, desde explicar que se pode fazer uma determinada disciplina como é o caso do Teatro, mesmo sendo evangélico; a utilizar frases bíblicas em sala de aula em frases para trabalhar questões de linguagem e interpretação; ou desvincular festas de seu sentido religioso original, como é o caso da Festa Junina que se tornou "Festa na Roça"; até mesmo diminuir as notas quando a redação de um aluno é sempre sobre um tema bíblico. Maria Edi da Silva observa em sua pesquisa que as crianças evangélicas geralmente são proibidas pela família de participarem não só da festa

\footnotetext{
${ }^{107}$ Refere-se do $6^{\circ}$ ao $9^{\circ}$ ano, alunos já são adolescentes.

${ }^{108}$ Refere-se do $1^{\circ}$ ao $5^{\circ}$ ano, alunos ainda são crianças.
} 
junina, também das relacionadas ao carnaval e ao Natal. A proibição possivelmente fica mais difícil no caso dos adolescentes da escola municipal Cartola. A hipótese de Silva é a de que aquilo que a escola propõe a partir de um caráter lúdico, passa a ter um viés devocional para as famílias dos alunos evangélicos. Ao utilizar a perspectiva de análise do reconhecimento, esta autora conclui que a escola pública não tem contemplado a diversidade religiosa dos seus educandos, embora ela também observe a criação de estratégias para a representação das outras religiões que não a da maioria.

Allan de Carmo Silva (2013) também observa na escola que pesquisa em Nova Iguaçu, na Baixada Fluminense, que na Festa na Roça não se fez alusão a nenhum santo católico. Sua hipótese é que assim ocorreu para evitar embates entre professores e responsáveis pedagógicos. Como também se deu na distribuição de "doces de Cosme e Damião" realizada geralmente por católicos, candomblecistas e/ou umbandistas. Segundo o que esse autor constata, são proibidas pelos pais e mães dos alunos evangélicos. A estratégia de alguns deles era adiar tal distribuição para o dia das crianças no mês seguinte ou então distribuir para quem aceitasse do lado de fora dos portões da escola. Na escola pública de Santo André observada por Valente não se viu a presença de símbolos religiosos durante as comemorações.

Em alguns casos, os professores pesquisados dizem precisar ficar mais atentos às palavras que utilizam. A remissão ao "diabo", "capeta”, “demônio" em sala de aula é geralmente um problema e os que são vistos como "macumbeiros" são vinculados a tais figuras, além do que seja referência ao povo negro especificamente. $\mathrm{O}$ pentecostalismo reconhece as religiões afro-brasileiras em seus aspectos mágicos como a manifestação do "diabo", assim, rejeitam tais religiões por considerarem-nas demoníacas e não falsas ou mentirosas (Campos e Mariz, 1998). Reginaldo Prandi (1992) relaciona os dois segmentos - o pentecostal e afrobrasileiro - ao processo de "remagicização", isto é, de valorização da magia que se deu no Brasil nos últimos anos do século XX. Se as interpretações são diferentes, isso implica em um novo conflito. Em geral, entretanto, esse grupo de alunos é visto pelos professores da escola municipal Cartola como uma questão. 


\subsection{4}

\section{“Então, eu vejo que tem intolerância de tudo quanto é, sabe?”}

O uso de palavras com um viés negativo pelos alunos nos remete à percepção dos professores sobre o preconceito, a discriminação e a intolerância religiosa no ambiente escolar. Essa é uma discussão que merece ser notada e foi bastante citada pelos professores entrevistados. Ainda parece corriqueira ${ }^{109}$ a ideia de "macumba", ou "macumbeiro" como algo pejorativo. A música da capoeira ainda é a "música de macumba”. Mais uma vez, são as religiões espíritas e afro-brasileiras as mais citadas por serem discriminadas. A maioria que se referiu ao tema, o percebe como algo negativo, apesar de só abordarem tal assunto quando ocorre alguma situação específica, entendem-na como uma oportunidade pedagógica. Cláudia, falou o seguinte:

Eu percebo uma, uma religião sendo muito massacrada. Que é a questão do espiritismo. Isso até o jogo de capoeira aqui embaixo, quando eles escutam, eles: "Ah, lá [vem], a música de macumba!" Então, a religião do espírita, o Espiritismo, o Candomblé, a Umbanda, ela é muito ainda malvista entre eles. Também porque a gente tem é um bom número de alunos evangélicos, né? E os evangélicos, eles têm essa coisa mais, mais pautada, nessa, nessa, nessa, [de] ser contra, né? O espiritismo. De achar que, nesse sentido, é coisa realmente do diabo.

E Tatiana destaca o preconceito contra os alunos evangélicos:

(...)eu vejo muita intolerância, inclusive tem um aluno que é da igreja (...) que os alunos sacaneiam muito ele, por que parece que na Rocinha ele deve andar muito com aquelas roupas, sabe? (...) E ai chamam ele de "pastor", ai ele faz bagunça e a sala "pô, só na igreja que você se comporta", "é, pastor". (...) então, eu vejo que tem intolerância de tudo quanto é, sabe? Tem mais em relação as religiões afro, mas tem com evangélico, entendeu?

Ou então contam com os momentos no currículo oficial em que se deveria tratar a história e a cultura africana e indígena, Cláudia vê seu trabalho como "tentar desconstruir algumas coisas". Em um dos casos, tais situações são vistas como uma "brincadeira". Pode-se dizer que metade dos professores que abordou o tema associou os alunos protestantes como autores de tais discriminações, a outra metade falou de uma maneira mais geral dos alunos.

\footnotetext{
${ }^{109}$ Uma fala de um dos pesquisados de Caputo (2012) para se referir a isso: "nunca me discriminaram, a não ser aquele preconceito 'normal' de me chamarem de macumbeiro e de acharem que macumbeiro sempre está pronto para fazer mal para alguém” (idem, p. 201).
} 
Nos últimos anos têm ganhado destaque pesquisas que se debruçam sobre o tema da intolerância religiosa no ambiente escolar, que se dão, apesar das mudanças no campo religioso, em "solo católico" (Giumbelli, 2007, p. 175). Rachel de Souza da Costa Oliveira (2014) focou nos casos que envolviam os adeptos da Umbanda. A escola para o grupo pesquisado dessa autora aparece como um espaço cerceador e uniformizador, os evangélicos e também os "sem religião" são os principais autores, incluídos aí professores e alunos. Os episódios se materializam na "histórica depreciação, subalternização e marginalização da religião" (Oliveira, 2014, p. 82) e os sentimentos dos estudantes eram os de "chateação, incompreensão, diminuição e constrangimento" (idem, p. 97) em situações tidas geralmente como "brincadeiras" e "chacotas" (idem, p. 84). Nesse sentido, muitos ainda não se sentem à vontade para expor sua religião, outros preferem o embate direto.

Já Stela Guedes Caputo (2012) que estudou crianças do Candomblé, destaca a estratégia que elas normalmente possuem. Por se sentirem envergonhadas, tornamse "invisíveis" para escapar da discriminação e escondem o que podem para não serem associadas à religião que praticam. Apesar da discriminação acontecer em diferentes lugares, a escola é lembrada como “o pior deles" (Caputo, 2012, p. 197). Joycimar Lemos Barcellos Zeferino (2016) também traz exemplos de situações de intolerância na escola em que pesquisa, não só em relação a alunos adeptos das religiões afro-brasileiras, embora principalmente eles sejam os principais alvos. Relata a dificuldade dos funcionários da escola em respeitar os rituais e preceitos ou o relativo espanto quanto a eles, o que geralmente acarreta dias de aula perdidos e também situações desencadeadas pelos próprios alunos de zoarem as religiões uns dos outros como ocorre na Cartola.

Tanto Zeferino, quanto Caputo e Oliveira observam escolas no estado do Rio de Janeiro. Maria Edir Silva relativiza e afirma que no calendário escolar os elementos afro-brasileiros ganham espaço em datas especificas, geralmente o carnaval e o dia da consciência negra, isso no caso da escola que pesquisou no Recife. Para esta autora, ora eles são caracterizados de maneira positiva, ora de forma negativa. É interessante notar, no entanto, que a maioria das pesquisas que focam nas crianças e adolescentes pertencentes às religiões afro-brasileiras e a relação que desenvolvem com a escola pública partem dos terreiros e daí chegam às escolas, 
esse é o caso de Caputo e também de Oliveira. Sem dúvida, isso ocorre dada a dificuldade de tocar nesse assunto pela via da própria escola. Há uma objeção em tornar esse um problema da escola, ele é visto muito mais como um problema dos grupos religiosos que sofrem preconceitos, discriminações e intolerâncias.

Como abordado por uma professora da Cartola, apenas os professores que possuem alguma ligação com o tema da história e da cultura afro-brasileira e indígena acabam ensinando sobre tais temas aos alunos. Situações como essa são comuns em outras pesquisas e muitas vezes a questão religiosa é um impedidor. Na escola pesquisada por Allan do Carmo Silva, por exemplo, uma professora teve dificuldade de realizar um projeto relacionado ao dia da consciência negra, sem que deixasse de lado as questões ligadas às religiões afro-brasileiras. Ele não pôde ser realizado por ir de encontro à religião predominante naquela escola, sendo necessário que no ano seguinte tal tema fosse inserido aos poucos por esta professora. A orientadora educacional evangélica disse ao pesquisador que a inserção da temática no currículo escolar trouxe muitos pontos que se distanciavam da sua religião, daí a sua proposta era a de não se aprofundar neles. Gabriela Valente também verifica isso em sua pesquisa numa escola pública no estado de São Paulo, uma professora presbiteriana não terminou de ler um livro para os seus alunos quando viu que a grande heroína da história era Yemanjá, uma Orixá. Tal final foi considerado por ela algo "estranho". Essa autora chama atenção que os princípios pessoais e suas percepções sobre quais cidadãos gostariam de formar, influenciam os professores, deixando os valores religiosos evidentes.

Reginaldo Prandi (1992) afirma que as religiões afro-brasileiras se iniciam como religiões étnicas e se tornam religiões para todos, na medida em que acreditam que cada seguidor deva ocupar o seu lugar de direito no mundo. Apesar de permanecer com tal marcação como religiões originalmente ligadas a um grupo específico ainda hoje. Um dos movimentos da mudança no campo religioso brasileiro também tem sido o retraimento ou o fraco crescimento da declaração de adeptos dessas religiões nos últimos censos do IBGE, no de 2010 representava $0,3 \%$ da população (Teixeira, 2014). Faz-se a ressalva da dificuldade em estimar tais grupos ainda contemporaneamente, embora pudesse se imaginar que eles experimentariam mais tranquilidade em se declarar como tais, quando comparamos a outros momentos 
históricos de perseguição institucionalizada, como apontado no capítulo anterior. Faustino Teixeira afirma que as circunstâncias históricas de constituição dessas religiões no Brasil e o aspecto sincrético que veio daí até esse momento fazem com que muitas pessoas se declarem como "católicas” ou “espíritas” (Prandi, 2013 apud Teixeira, 2014). A Umbanda e as variantes do Candomblé não são apenas alvos de combate, também objetos do proselitismo evangélico (Prandi, 1992). E se é verdade que tais religiões são geralmente ligadas às camadas populares e é na escola pública que tais camadas estão, é esse um dos espaços propícios ocorram casos de preconceitos, discriminação e intolerância religiosa.

\subsection{5}

\section{"A gente, às vezes, acaba tendo que fazer mais o outro lado dos valores, do que é certo"}

A quinta categorização a ser elencada é um achado da pesquisa apontado pelos próprios professores da escola municipal Cartola. Ao longo das primeiras entrevistas, geralmente ao se falar das famílias dos estudantes muitas vezes percebidas como ausentes, evocava-se a ideia de uma "crise de valores". Eles manifestam a necessidade de ensinar princípios aos seus alunos, por acreditarem que esta também é uma função sua enquanto professor ou então porque percebem que a família não faz isso. Uma vez que "faltam" os pais ou por terem baixa escolaridade ou por precisarem se ausentar por conta do trabalho.

No entanto, se o significado de "valores" parece um pouco amplo e abstrato, busquei que eles exemplificassem. O caminho de argumentação de cada um foi muito subjetivo, mas algumas generalizações podem ser feitas: falam de honestidade, respeito, felicidade, acreditam que seus alunos xingam e brigam muito, exprimem sobre a importância de não roubar, acreditam que exista muito machismo entre eles, falam sobre a importância dos estudos e do trabalho, da criação de sonhos, de perspectivas, de futuro. Em geral, valores "de como tem que se agir, ser, como você tem que se portar" como resume uma das professoras. São condutas, comportamentos, atitudes e regras que qualificam como necessárias. Um exemplo é a fala da professora Mariana: “Assim, senta na cadeira, faz silêncio, não é pra ficar andando na sala, respeita seu colega, não é pra xingar, não é pra puxar o cabelo da sua colega, sabe? Assim, o básico do básico”. 
Segundo a professora Cláudia, há na questão dos valores um grande descompasso. As crianças dessa geração estão num caminho e a escola está em outro, no meio estão os professores tentando juntar as duas coisas. Mas, não tem se conseguido chegar nesse "meio", pois os professores, ela incluída, não conseguem "entender como eles entendem". Ela exemplifica falando sobre o poder de decisão que os jovens possuem nas relações hetero ou homoafetivas estabelecidas entre eles, na sua opinião, muitas vezes sem estar preparados para tal. São valores diferentes de uma realidade que ainda a choca. Isso porque muitas vezes os próprios professores "não querem se debruçar sobre algumas questões", dada a vida corrida que possuem, apesar de muitas vezes isso significar uma escolha, como ela coloca. A ideia de que para ser alguém é preciso estudar também não é muito mais defendida entre os seus alunos que pertencem a essa geração "mais recente".

Para uma das professoras, os alunos trazem "os valores do Nordeste", entendidos por ela como a crença na educação, o respeito aos mais velhos, também machismo e homofobia, uma visão deveras reducionista. Outros valores que são comentados são os relacionados à competitividade de uma sociedade capitalista na qual todos estão inseridos. Fala-se com os alunos do Ensino Fundamental na escola pesquisada, sobre a seletividade e a concorrência no mercado de trabalho, as dificuldades da vida. E ainda se ensina sobre o que é visto como "certo" e o que é "errado": roubar é errado, entrar no tráfico é errado.

Um professor "passa valores" pela sua prática enquanto indivíduo. Uma professora reflete que conhece muito pouco sobre o mundo que seus alunos vivem e, por isso se sente numa situação complicada de dizer o que é certo, embora acredite na necessidade do ensino de valores. O professor Mauro dá conselhos: "não vale a pena ser traficante, nem ser dono do morro", que "isso ai é vida errada". Geralmente, associa-se os comportamentos dos alunos da escola ao lugar em que vivem: a favela. Esse é um espaço idealizado pelo senso comum escolar como um lugar pobre, com moradores imigrantes do Nordeste, com famílias geralmente ausentes, fazem a ressalva, por conta do trabalho geralmente, com filhos que são violentos e não sabem se comportar, mais recentemente, com evangélicos. Os valores seriam então conselhos e dicas imprescindíveis mais para esses alunos que para quaisquer outros e possuem um caráter civilizador, ora mais ora menos, "de 
dentro" da religião, como colocado por uma professora quando questionada se ela trabalha a partir de uma moralidade com os seus alunos e se ela se utiliza de sua vivência religiosa para tal:

não é bem religiosa, porque eu fico falando em religião, Deus me livre, né? Ainda mais pra um bando de crentes que eu digo "vocês são uns bando de crente, eu não sou não", mas eu converso com eles mas não trago nada da minha religião, eu trago coisas dentro da religião né? O que ele tem que ser? Ele tem que ser honesto, tem ser justo então eu passo essas coisas, o que pra vocês, deve ser, um caminho errado então eu procuro passar isso, tá? Como eles tem que se portar e o que a vida pra eles... como devem se portar em situações na vida, que eles não vão ter papai e mamãe a vida inteira.

Muitas vezes quando se defende o Ensino Religioso enquanto disciplina, se dá pelo viés do ensino de valores aos alunos. Isso foi constatado por Silva (2013) entre os seus entrevistados, além da defesa do uso da religião para a promoção de "valores éticos", percebidos pelo autor ligados apenas à religião predominante entre os profissionais da escola por ele pesquisada, apesar de estarem envoltos numa perspectiva de "valores comuns". Zeferino (2016), ao se aprofundar na discussão do Ensino Religioso especificamente na rede municipal do Rio de Janeiro, aponta que atualmente as escolas públicas municipais que ofertam tal disciplina são apenas as integrais e a proposta é de ampliar tal modalidade de ensino para toda a rede até o ano de 2020, o que implica também em ampliar a oferta de Ensino Religioso.

Como se trata de uma disciplina facultativa, é oferecida como alternativa aos alunos que não optem pelo Ensino Religioso Confessional, a chamada "educação em valores" ${ }^{110}$. A pesquisadora observou que, na prática, por se tratar de uma disciplina ministrada pelos professores polivalentes, comumente eles acabam encarando-a como um horário que deveriam estar "livres" e como possuem alunos cuja responsabilidade é deles, aproveitam o tempo da maneira que acreditam ser menos onerosa. Dessa forma, incentivam os alunos, por meio de tarefas que eles provavelmente não gostam de cumprir, a mudarem a sua opção e participarem da disciplina de Ensino Religioso dada no mesmo horário.

Para além do Ensino Religioso enquanto disciplina, Valente também encontrou em sua pesquisa a fala de uma professora católica que acreditava na importância de se

\footnotetext{
${ }^{110}$ Aqueles tidos como universais, como consta no caderno pedagógico da disciplina: perseverança, autonomia, respeito, solidariedade, amizade, verdade, compreensão, cooperação, honestidade e ainda temas como preconceito, discriminação e cultura de paz (Zeferino, 2016, p. 84).
} 
tratar alguns assuntos pertinentes à religião, mas sem "incutir" a prática religiosa. O objetivo seria então o de "despertar" nos estudantes a busca por um suporte e segurança trazidos pela religião. Isto é, na visão dessa professora, trazer a religiosidade que possuíam enquanto indivíduos, sem remeter à institucionalidade da religião. A laicidade da escola seria um empecilho para isso, confessa. Tal enfoque aproximou-se muito de uma das professoras da escola municipal Cartola, quando listava os valores "de dentro" da religião: bondade, honestidade, fé etc. e de outra professora que se referiu ao "temor a Deus" como algo que falta entre seus alunos. Em contraposição a tal perspectiva, a pesquisadora observa uma professora presbiteriana que tem na sua profissão o sentido de "missão", de socializar aqueles que seriam "carentes" de valores, por serem marginalizados econômica e socialmente e que prioriza o conhecimento enquanto fundamento da educação.

\subsection{6 \\ "'Ah, mas por que, professora, que esse feriado existe, se nem todo mundo é católico? É uma boa pergunta, né?"}

O último enfoque é o do olhar sobre a relação entre escola e religião feita pelos professores pesquisados. Não se teve problema sobre religião em sala de aula, preferiu-se não comentar, falou-se que se o assunto tivesse aparecido no texto discutido, aí se falaria. Uma professora lembrou que a escola é laica. Essa dimensão da vida das pessoas, inclusive do professor e de seus alunos é compreendida como um tabu. A professora Vanessa disse que "a questão da diversidade é a questão do momento (...), em todos os aspectos: do gênero, das religiões e tal”. Os alunos, afirma, perguntam sobre tudo, comentam sobre tudo o que acontece e querem saber a opinião do professor. Como quando, e ela exemplifica: sobre uma propaganda em que um casal de meninas se beija e ela diz que tal questão não tem nada a ver com o tema que ela estava trabalhando naquele momento. Na sua visão, o seu papel não é o de "defender essa posição ou aquela posição, porque, senão eu já tô tomando partido, mas é difícil, é difícil, né." São questões, como a trazida no exemplo, Vanessa coloca, que estão muito em evidência nos dias de hoje, o que requer um cuidado maior para conduzir tais debates, “(...) tentando uma certa neutralidade.”

Os professores possuem estratégias: assumem sua própria crença para contrapor os alunos, busca-se explicações históricas ou o que se compreende como "comuns" a todas as pessoas, afinal, como coloca a mesma professora: todo mundo busca uma 
"energia positiva, que se chama Deus nessa ou naquela religião, uma tem vários deuses, outras não”. Outrossim, possuir uma religião é percebido, em geral, como algo positivo pelos professores. Há aí uma associação direta entre ser religioso é igual a ser bom ${ }^{111}$. Uma vez que, ela é, muitas vezes, vista como uma "aliada", leva a uma maior disciplina e mais "limite", como colocaram. O ponto de referência para a comparação será geralmente o catolicismo, como já dito anteriormente, dado o seu caráter de invisibilidade na cultura brasileira. A religião possui uma natureza "salvacionista" ou "redentora" na perspectiva dos professores da escola municipal Cartola e isso é recorrente em outros estudos também (Zeferino, 2016; Cavaliere, 2006; Cavaliere, 2007; Cunha, 2013 entre outros).

Allan do Carmo Silva percebeu em sua pesquisa em escolas públicas da cidade de Nova Iguaçu que grande parte de seus pesquisados aprovavam a prática de orações entre professores e com os alunos, a apresentação de alunos em dias festivos com músicas religiosas, textos religiosos fixados em sala de aula entre outras coisas. $\mathrm{O}$ espaço escolar foi percebido como um local em que se afixavam cartazes e outras decorações com teor religioso, principalmente do segmento predominante dos profissionais e das famílias de alunos daquela escola, o protestante. Uma outra situação de grande presença de símbolos religiosos em uma escola pública também foi a observada por Luiz Antônio Cunha (2013): eram exibidos uma Bíblia, um crucifixo e uma imagem de Nossa Senhora Aparecida, além de vários cartazes com salmos bíblicos, nesse caso, a predominância era católica. Já na escola paulista observada por Valente (2015), a presença religiosa era mais sutil e difusa, uma vez que diferente do que foi percebido em Nova Iguaçu por Silva e também por Cunha, não havia referência às religiões em cartazes ou na decoração daquela escola, esse foi o caso da Escola Municipal Cartola.

O ensino de valores é um dilema para os professores, a presença da religião entre os alunos, o fato deles morarem em favelas como a Rocinha, a discussão em sala de aula de temas que consideram "polêmicos", como e exemplificado por uma professora: a questão da diversidade e do gênero. O trabalho de Ana Maria

\footnotetext{
${ }^{111}$ Sobre o ensino religioso facultativo na LDB, por exemplo, Sá Carneiro e Giumbelli (2006) questionam: se tal disciplina é definida como um componente curricular importante porque integra a formação para a cidadania, poderia sugerir o pressuposto de que uma pessoa "religiosa" seria melhor cidadã, porque professa uma crença, em detrimento de outras que não.
} 
Capitanio (2014) especificamente sobre a relação entre crenças religiosas e gênero no ambiente de uma escola pública municipal localizada no $\mathrm{ABC}$ paulista constatou que os dois aspectos estão constantemente entrelaçados e impregnados nas práticas das professoras ${ }^{112}$. Os professores da Cartola se questionam qual o papel da escola nessas situações e qual o seu próprio papel enquanto professores. Muitas vezes, ocorre um impasse quando o conhecimento escolar se choca com o das crenças, o conhecimento trazido pelos próprios alunos. Um dos nossos professores fala de um dilema de autoridade: a palavra do professor e a do pastor. Muitas vezes o segundo possui a importância de uma verdade última, já que embasada no livro sagrado. Se pensarmos na escola como o espaço do desencantamento por excelência, há mesmo uma dificuldade aí. Como dialogar com as crenças que os alunos trazem de suas vivências religiosas?

Valente e Setton (2015) constatam que a religiosidade é acionada na escola pública pesquisada pelos professores como suporte, como uma necessidade para garantir algum alívio e força espiritual, afim de ajudar na atuação em sala de aula. Ela preenche uma lacuna institucional, já que há um vazio nesse aspecto. Daí a estratégia individual de: se nada é identificado para resolver os problemas pedagógicos, o jeito é apelar para as próprias crenças religiosas. Como definem as autoras, constata-se o "uso pedagógico do religioso" (Setton e Valente, 2015, p. 188). A religião não só é vista como redentora para os alunos, também para os professores. Isso é percebido pelo trabalho de Capitanio, as professoras estudadas por ela se viam como vulneráveis à violência dentro da escola, por vezes compreendida como indisciplina, e a partir daí justificavam ações como a oração no início das aulas e o constante uso do discurso religioso. Uma maneira, na visão de Capitanio, de controlar o comportamento dos alunos. E na percepção das professoras, uma forma de afastar o "mal" da escola e lhes possibilitar ter paciência e autocontrole durante as aulas. Uma prática que era comum na época em que essas professoras estavam nos bancos escolares, daí o não estranhamento de tais atitudes.

\footnotetext{
${ }^{112}$ Algumas práticas citadas por Capitanio: “as repressões pelos modos de sentar das meninas 'para não mostrar a calcinha', o estranhamento da possibilidade do tom de voz dos meninos ser baixo (...), a imposição de limites dos movimentos dentro de sala de aula, a preocupação com a organização das carteiras e do material escolar entre outras" (Capitanio, 2014, p. 62).
} 


\subsection{7 \\ O "nós" versus "eles"}

As falas dos professores da escola municipal Cartola podem ser lidas sob um enfoque em que tais adultos observam seus alunos, adolescentes, diferenciando-se deles. Ou seja, numa perspectiva de separação entre "nós" versus "eles", acabam então por se definir relacionalmente. Seus alunos são o "outro" que mora na favela, que é de uma classe social mais baixa, que é acostumado com a violência e por tudo isso é agressivo e não sabe "se comportar", que possui uma família pouco presente, que é carente de valores e é, mais recentemente, evangélico, autor dos preconceitos, discriminações e intolerâncias religiosas na escola em que atuam. Eles, os professores pertencem a uma camada da população mais privilegiada em relação aos primeiros e "pisam" no solo católico, mesmo que ativamente não sejam adeptos dessa instituição religiosa, mas no sentido de participarem dessa cultura tradicionalmente.

Logo, é de especial importância o não conhecimento do mundo dos seus alunos, principalmente da sua diversidade religiosa no tocante aos estudantes evangélicos em geral. Por vezes, o preconceito religioso se vincula ao social. $\mathrm{O}$ viés da região de localização da escola pesquisada atuou fortemente para tais respostas. Como exemplo da escola observada por Silva, localizada na Baixada Fluminense, há uma grande diferença: ali os professores e gestores eram evangélicos, na Cartola eram apenas os alunos. Na primeira situação era "natural” ser evangélico e na segunda, o "natural" está mais ligado a uma tradição do catolicismo enquanto identidade da maioria, invisível. Assim como na sociedade brasileira como um todo, como salientam Christina Vital da Cunha, Paulo Victor Leite Lopes e Janayna Lui (2017), percebe-se um preconceito generalizado em relação aos evangélicos dada a associação direta deste grupo em que pese o comportamento extremista e conservador principalmente dos seus líderes religiosos e políticos, os “"outros” em relação ao 'nós' - que significariam os católicos, seus rituais, estética e gramáticas" (idem, p. 125).

A interrogação em relação ao desconhecido é esperada, afinal é preciso compreender: geralmente os evangélicos vivem em um "mundo separado", não apenas do ponto de vista ético, como também o de uma rotina de vida (Silva, 2011, 
p. 53) e mais ainda, de visão de mundo. Além disso, é injusto esperar dos professores que eles sejam profundos conhecedores das diferenças. Entretanto, é inevitável que a nova realidade traga mudanças para a rotina da escola, especialmente na relação professor-aluno e aluno-aluno. Ainda mais quando lembramos que é principalmente nas camadas populares que está na escola pública, onde estão os evangélicos pentecostais e os afro-brasileiros em que se observa uma tensão, não a única e não só desses grupos religiosos, mas muito importante de ser destacada. Está aí a disputa.

Quando Weber (1982) fala da emancipação da esfera religiosa em detrimento de outras, para o que é pertinente aqui, a intelectual, ele afirma que elas estarão em constante tensão, quando não numa concorrência de visões de mundo que se pretendem últimas para os mesmos aspectos da vida individual e social. $\mathrm{O}$ autor reconhece a força da ética religiosa ao perceber na saída puritana da vocação a afinidade eletiva para o desenvolvimento do capitalismo. Uma ética que se construiu como religiosa e que se deslocou dessa origem em grande medida. Talvez seja por isso que os professores reconheçam a religião como uma aliada no processo educacional, como tendo uma afinidade eletiva. No entanto, têm dúvidas sobre os limites do seu próprio papel, esta é realmente uma questão em aberto e de suma importância.

Os aspectos iluminados por Talal Asad (2010) podem ser relevantes nesse momento. Para este autor, a separação entre símbolo e significado é Ocidental e a própria definição do que é religião é também histórica. O símbolo não é veículo para a evocação de alguma concepção sobre algo, é a própria concepção. A sua crítica a Geertz é que este autor separaria dois níveis: o cultural, onde estariam os símbolos e o social e o psicológico. Para Talal Asad, os símbolos não se separam dos estados mentais. Assim, poderíamos compreender com este autor que a própria construção dos valores em si mesma se dá de maneira conjunta. Há influência da religião e, do que se considera civilizado que, claro, tem a ver com uma construção histórica da qual grande parte dos alunos da escola municipal Cartola não fazem parte. Ao falarem de honestidade, felicidade, respeito, os professores explicitam as concepções que possuem sobre tais símbolos. Portanto, há uma discricionariedade, uma vez que depende do repertório de cada professor, da sua idade, da sua posição 
pessoal sobre os temas, da maneira como compreende a sua profissão, da disciplina que leciona para elencar alguns dos possíveis aspectos e da sua própria subjetividade. Nada disso está separado. Tal conjunção de fatores, de um lado, é inevitável e imprescindível, tem a ver inclusive com a autonomia do professor em sala de aula. De outro, significa que não há um consenso sobre como agir em relação a determinados assuntos, afinal é muito difícil delimitar as fronteiras entre o que é ou não papel da escola.

A mudança no campo religioso brasileiro e, por conseguinte, na sociedade como um todo, apesar de percebida, ainda é uma novidade para esses professores. É um "problema" novo. No passado, esta não parecia ser uma questão. O sincretismo hierárquico as "encobria", e pouco era percebido, pelo menos por parte de uma camada estabelecida da população, como algo negativo. Com as religiões evangélicas, especialmente as pentecostais, isso não é mais possível. Elas reconhecem as religiões afro-brasileiras de forma antagônica em seus aspectos mágicos e requerem um pertencimento religioso exclusivo.

\section{2}

\section{As recentes propostas legislativas e resoluções para o currículo e a disputa moral e religiosa}

As políticas públicas, que são executadas no chão da escola são resultados muitas vezes de disputas de diferentes grupos que geralmente possuem diversas perspectivas da sociedade que querem construir, aliás de "tipos" de indivíduos querem formar para essa sociedade. Um exemplo claro disso foram as duas fases de debate em que católicos e escolanovistas buscaram defender os seus pontos de interesse para a escola pública brasileira, como vimos. Nesse momento, aprofundaremos em algumas propostas legislativas e resoluções que se conectam às discussões feitas há pouco e onde também se dão as disputas entre religião, moralidade e escola.

As legislações, normas e orientações ${ }^{113}$ que foram sendo criadas no âmbito educacional pós 1988 são em grande medida fruto de consensos entre o espaço da

\footnotetext{
${ }^{113}$ Nos dois anos seguintes à aprovação da LDB, foram definidos os Parâmetros Curriculares Nacionais (PCNs) que versaram sobre os temas transversais não pertencentes a nenhuma disciplina específica, devendo ser tratados por todos os professores. Alguns deles: ética, pluralidade cultural e orientação sexual. Posteriormente em 2013, foram publicadas as Diretrizes Curriculares Nacionais
} 
política, a partir do Poder Executivo - do Ministério da Educação -, de diferentes movimentos sociais e também do conhecimento acadêmico acumulado em torno dos temas discutidos. Se as definições de ética, valores, cidadania, democracia, cultura entre outras na Constituição, no Estatuto da Criança e do Adolescente (ECA) e na LDB pareciam inicialmente amplas, buscou-se, ao longo dos anos qualificar tais conceitos a partir de determinadas perspectivas. Recorrentemente, o que se define é qual o papel que a escola, incluindo o papel dos gestores e professores, deve desempenhar na formação das crianças, jovens e adultos e, para além disso, que tipo de sociedade se aventa para o futuro. Sem esgotar com isso tal definição, uma vez que ela é percebida enquanto processo, isto é, está sempre em permanente construção. Leva-se em conta a multiplicidade dos indivíduos a serem formados, as diversidades e diferenças culturais e sociais as quais tais indivíduos experimentam fundamentalmente percebendo a educação escolar enquanto um direito.

A Base Nacional Comum Curricular é o mais recente documento educacional previsto para delimitar o currículo. O Plano Nacional de Educação aprovado como lei em 2014 aponta como uma de suas metas para os próximos dez anos a construção desse documento, que diferente dos outros tratados até agora possui status de lei ${ }^{114}$. Para tanto, foi montada no ano seguinte uma comissão de especialistas e professores de todas as disciplinas de diferentes redes ao redor do Brasil que fizeram uma primeira versão da BNCC para toda a educação básica. Em seguida, ela foi disponibilizada ao público para receber sugestões e críticas e uma segunda versão foi apresentada. Foram realizados seminários estaduais e a versão final foi disponibilizada para votação do Conselho Nacional de Educação.

Constituiu-se, como colocou Marcelo Baumann Burgos (2015), uma oportunidade única para que a sociedade participasse amplamente do debate sobre o currículo. Seu objetivo foi o de balizá-lo numa perspectiva de garantir um mínimo comum a todas escolas brasileiras públicas e privadas. Sem, no entanto, tornar-se um

(DCNs) em que se regulamenta, entre outras coisas, a Educação das Relações Étnico-Raciais e para o Ensino de História e Cultura Afro-Brasileira e Africana e a Educação em Direitos Humanos.

${ }^{114} \mathrm{Na}$ sua meta 7, a primeira estratégia: "estabelecer e implantar, mediante pactuação inter federativa, diretrizes pedagógicas para a educação básica e a base nacional comum dos currículos, com direitos e objetivos de aprendizagem e desenvolvimento dos (as) alunos (as) para cada ano do Ensino Fundamental e médio, respeitada a diversidade regional, estadual e local" (PNE, 2014). 
documento engessado, uma vez que previu uma parte diversificada que deve ser tarefa das redes estaduais para garantir que as diferenças regionais possam também compor o currículo. Embora isso também tenha levado a controvérsias ${ }^{115}$. Ainda sob o governo de Dilma Roussef houve uma primeira polêmica sobre o currículo de História ${ }^{116}$ e também, o que nos interessará mais de perto, em relação à inserção do currículo de Ensino Religioso, o que persistiu no governo de seu vice que se alçou presidente, Michel Temer em agosto de 2016. Somada a ela também houve o debate da inserção ou não das discussões de gênero em diferentes momentos na BNCC que também será aprofundado ${ }^{117}$.

\subsection{1}

\section{Gênero e seus debates e "ideologias"}

Os documentos normativos educacionais têm buscado ao longo do tempo ampliar o papel da escola para a formação dos indivíduos em suas diversas dimensões. Os Parâmetros Curriculares Nacionais (PCNs) trouxeram a orientação sexual como um dos seus temas transversais. Com isso, buscou-se inspirar uma discussão que tratasse das diversidades sexuais e do debate de gênero dentro das escolas públicas brasileiras, independente de delimitar tais discussões como pertencentes a uma determinada disciplina ou outra.

Foi proposto em 2011 o programa "Escola sem homofobia", um dos "braços" do projeto "Brasil sem homofobia" do Governo Federal, lançado em 2004. Um dos seus objetivos era o de formar educadores para as questões ligadas à gênero e sexualidade, e assim

'contribuir para desconstrução de imagens estereotipadas sobre lésbicas, gays, bissexuais, travestis e transexuais, e promover como ganho a convivência e o respeito em relação ao diferente'. Seu público-alvo, como indicado no mesmo documento, era toda a 'comunidade escolar e, em especial, alunas/os do ensino fundamental $\left(6^{\circ}\right.$

\footnotetext{
${ }^{115}$ A Associação Nacional de Pós-graduação e Pesquisa em Educação (ANPED) e a Associação Brasileira de Currículo ( $\mathrm{ABdC}$ ), por exemplo, posicionaram-se contra o documento por acreditarem, entre outras coisas que a Base era um projeto homogeneizador e centralizador (idem, p. 23).

${ }^{116} \mathrm{O}$ currículo da primeira versão dessa disciplina que trazia história ocidental de base europeia apenas no Ensino Médio foi acusado de "obscurantista", pois "mutila os processos históricos globais" na fala de Ronaldo Vainfas. E priorizava a história das Américas e da África, com isso "equivale a um decreto ideológico de refundação do Brasil" nos dizeres de Demétrio Magnoli (idem, p. 22). Na segunda versão foi modificado e já trazia as bases da história ocidental com a Grécia Antiga desde o $2^{\circ}$ segmento do Ensino Fundamental.

117 A construção desse documento se deu num período muito conturbado para a política nacional nos últimos três anos. A elaboração oficial teve início em 2015, durante o governo Dilma Rousseff. Desde lá, a pasta da Educação já teve seis ministros diferentes e o país, dois presidentes e um processo de impeachment.
} 
ao $9^{\circ}$ ano) e do ensino médio' (2010, p. 11 apud Vital da Cunha e Leite Lopes, 2012, p. 110).

Quando estava para ser lançado, iniciou-se uma campanha de deputados e senadores, mas não só eles, identificados como religiosos e conservadores que passaram a chamar o material educativo do programa ${ }^{118}$ de "kit anti-homofobia" ou "kit gay", foi assim que ficou conhecido. Eles alegavam que por meio da distribuição do material haveria um "estímulo ao homossexualismo e à promiscuidade" 119 dentro das escolas e assim justificavam a sua tomada de posição. A pressão foi tanta que a distribuição do material e a capacitação prevista para os professores foram interrompidas pelo Executivo. $\mathrm{O}$ material educativo havia sido desenvolvido pela ONG Comunicação em Sexualidade (ECOS) e foi fruto de uma articulação entre o Ministério da Educação, ativistas do movimento LGBT e educadores de diversas partes do Brasil. Segundo Christina Vital da Cunha e Paulo Vitor Leite Lopes, uma das figuras centrais do debate foi o então deputado federal Jair Bolsonaro (PP/RJ), que à época se declarava como católico ${ }^{120}$, mais conhecido pelos seus posicionamentos a favor da Ditadura Militar. Além dele, a bancada evangélica e a católica ${ }^{121}$ também se articularam para questionar tal política. Ao final, acertou-se com o governo que as bancadas religiosas seriam ouvidas em todos os programas ou iniciativas do Executivo que tratassem das "questões de costumes" ou "comportamentais" (idem, p. 142).

Em 2014, ainda sob o Governo de Dilma Roussef, foram vetados no PNE os temas identidade de gênero e sexualidade nas escolas, o que se seguiu em vários Planos de estados e municípios ${ }^{122}$. Outra vez a pressão das bancadas religiosas foi importante, além delas, a CNBB divulgou nota à época afirmando que "a ideologia

\footnotetext{
${ }^{118}$ Composto por "1) um caderno de orientação para o educador, o "Caderno Escola Sem Homofobia'; 2) uma série de seis boletins elaborados com uma linguagem juvenil, voltado para a distribuição entre os estudantes; 3) um cartaz de divulgação do projeto na escola, em que se estimulava que a comunidade escolar procurasse ter mais informações sobre o projeto; 4) cartas de apresentação para os gestores e educadores, apresentando o projeto e indicado as melhores formas de trabalhá-lo; 5) e três vídeos educativos que, acompanhados por suas respectivas guias de discussão, poderiam funcionar como estimuladores, pontos iniciais de debate" (idem, p. 109).

${ }^{119}$ Disponível em: https://novaescola.org.br/conteudo/84/conheca-o-kit-gay-vetado-pelo-governofederal-em-2011 . Acesso em: 03 mar. 2018.

${ }^{120}$ Atualmente pertencente ao PSC. Em 2016 foi batizado no rio Jordão em Israel seguindo a tradição da maioria das igrejas evangélicas.

${ }^{121}$ Alguns deles: João Campos (PSDB/GO), Magno Malta (PR/ES), Marco Feliciano (PSC/SP), Eros Biodini (PTB/MG) e Roberto Lucena (PV/SP).

${ }^{122}$ Disponível em: http://www.ebc.com.br/educacao/2015/07/entenda-por-que-e-importantediscutir-igualdade-de-genero-nas-escolas. . Acesso em: 03 mar. 2018.
} 
de gênero desconstrói o conceito de família, que tem seu fundamento na união estável entre homem e mulher" ${ }^{123}$. A justificativa das bancadas era parecida, tal discussão "deturparia os conceitos de homem e mulher, destruindo o modelo tradicional de família" ${ }^{24}$. Falar sobre gênero seria uma tarefa dos pais e não da escola. Cedeu-se à pressão também dos grupos religiosos que diziam temer a invasão da escola por cartilhas voltadas para o público LGBT, uma alusão ao projeto de 2011.

A discussão de gênero na Base Nacional Comum Curricular foi uma das suas grandes polêmicas. A primeira versão previa como um dos seus princípios orientadores a promoção do respeito sem que houvesse diferentes discriminações, uma delas a de gênero. Tal discussão já era diretamente explicitada desde a Educação Infantil, passando por diferentes disciplinas - Linguagens, Arte, Educação Física e Biologia - no Ensino Fundamental e também no Ensino Médio em Biologia e Sociologia. A segunda versão diferenciou-se da primeira no Ensino Fundamental, a discussão de gênero aparece também em um dos tópicos da disciplina de Ensino Religioso ${ }^{125}$ e fazendo parte de um dos "temas integradores", o de "direitos humanos e cidadania". Além de se acrescentar em um tópico da Geografia dessa etapa de ensino. A terceira versão, já sob o governo de Michel Temer ${ }^{126}$, suprimiu a disciplina de Ensino Religioso e manteve como princípio norteador da Base o respeito e a valorização dos indivíduos, na sua diversidade incluindo aí a de gênero e também nas discussões específicas das disciplinas já citadas durante o Ensino Fundamental, acrescentando a de História.

Posteriormente, em junho de 2017, foi realizada na Câmara dos Deputados uma audiência pública para debater a exclusão das expressões "orientação sexual" e

\footnotetext{
${ }^{123}$ Disponível em: https://apublica.org/2016/08/existe-ideologia-de-genero/ . Acesso em: 03 mar. 2018.

${ }^{124}$ Disponível em: http://ultimosegundo.ig.com.br/educacao/2015-12-26/exclusao-de-genero-doplano-nacional-de-educacao-e-retrocesso-diz-educador.html . Acesso em: 03 mar. 2018.

${ }^{125}$ Uma de suas perspectivas: "ideias e Práticas religiosas/não religiosas: aborda as experiencias e manifestações religiosas nos espaços e territórios; as práticas celebrativas, simbólicas, rituais, artísticas, espirituais; a atuação das lideranças religiosas; as instituições religiosas e suas relações com a cultura, política, economia, saúde, ciência, tecnologias, meio ambiente, questões de gênero, entre outros" (MEC, 2016, p. 171 e 172). E especificamente como uma habilidade do nono ano: "elaborar questionamentos referentes a existência humana e as situações limites que integram a vida, articulados as questões socioambientais, geopolíticas, culturais, religiosas, de gênero e sexualidade, dentre outras" (idem, p. 480).

${ }^{126} \mathrm{O}$ Ensino Médio, que constava nas duas primeiras versões foi retirado, com a justificativa da Reforma do Ensino Médio decretada por esse governo.
} 
"identidade de gênero" da BNCC. Os representantes do MEC buscaram um ponto de equilíbrio entre os divergentes. De um lado, representantes de movimentos da sociedade civil, mais especificamente da população LGBT e também da educação defendiam a inclusão explícita do assunto na normativa. Falou-se que sem uma orientação clara, tal discussão ficaria a critério dos professores individualmente e nem garantiria que esse tema entrasse na sua formação. De outro, representantes de movimentos religiosos e do Escola sem Partido alegaram que "gênero" é um conceito subjetivo e repudiaram a sua presença na Base ${ }^{127}$.

Três meses depois, as frentes parlamentares evangélica, mistas Católica Apostólica Romana, em Defesa da Vida e da Família e mista da Família elaboraram um ofício pedindo ao presidente que retirasse o conceito de gênero da Base Nacional Comum Curricular $^{128}$. A justificativa era a consonância com as famílias brasileiras, tal solicitação serviria para "livrar as crianças de serem submetidas a uma ideologia destinada a desconstruir suas identidades" ${ }^{129}$. Cedendo às críticas, a quarta versão da Base, entregue ao CNE para votação inseria a discussão de gênero e sexualidade na disciplina de Ensino Religioso de uma maneira mais direta que na versão anterior.

Descritas como habilidades para o nono ano do Ensino Fundamental, ou seja, para adolescentes geralmente entre 14 e 15 anos que deveriam "discutir as distintas concepções de gênero e sexualidade segundo diferentes tradições religiosas e filosofias de vida" e "discutir as diferentes expressões de valorização e de desrespeito à vida, por meio da análise de matérias nas diferentes mídias" ${ }^{130}$. Tal tema com essa abordagem, no entanto, acabou não passando na votação do CNE. Desse modo, o documento final da BNCC para a Educação Infantil e o Ensino

\footnotetext{
${ }^{127}$ Disponível em: http://www2.camara.leg.br/camaranoticias/noticias/EDUCACAO-ECULTURA/536038-MINISTERIO-BUSCA-EQUILIBRIO-PARA-ABORDAGEM-DEGENERO-NA-BASE-CURRICULAR.html . Acesso em: 08 mar. 2018.

${ }^{128}$ Disponível em: http://www1.folha.uol.com.br/educacao/2017/04/1873366-ministerio-tiraidentidade-de-genero-e-orientacao-sexual-da-base-curricular.shtml . Acesso em: 25 fev. 2018.

${ }^{129} \mathrm{O}$ documento foi assinado pelo assinado pelos deputados federais Takayama (PSC-PR), Givaldo Carimbão (PHS-AL), Allan Rick (DEM - AC), presidente da Frente e o senador Magno Malta (PRES). Disponível em: http://www.cartaeducacao.com.br/reportagens/base-nacional-comumcurricular-e-alvo-de-grupos-religiosos/ e https://oglobo.globo.com/sociedade/educacao/cne-retiragenero-orientacao-sexual-da-base-curricular-22179063\#ixzz585e82lhC . Acesso em: 25 fev. 2018. ${ }^{130}$ Essa versão não foi divulgada publicamente pelo governo. No entanto, alguns jornais tiveram acesso ao texto. Disponível em: http://educacao.estadao.com.br/noticias/geral,base-curricularinclui-temas-como-genero-e-sexualidade-em-area-de-ensino-religioso,70002110265 . Acesso em: 24 fev. 2018.
} 
Fundamental, aprovado no final de 2017, não tocou no assunto, embora no minuto final o conselheiro do CNE que presidiu a comissão tenha tentado retomar todos os trechos suprimidos sem sucesso ${ }^{131}$. Uma das declarações do atual ministro da Educação, Mendonça Filho, foi que a Base Nacional Comum Curricular não estaria exposta a nenhuma "prisão à ideologia de gênero"132.

Em contrapartida, não se pode perder de vista a diversidade da atuação dos grupos religiosos. As Católicas Pelo Direito de Decidir (CDD $)^{133}$, por exemplo, encomendaram uma pesquisa ao IBOPE em 2017 sobre a percepção dos brasileiros e brasileiras em relação ao aborto e a educação sexual e a igualdade de gênero nas escolas. Falemos sobre o segundo e o terceiro assunto: apenas $9 \%$ dos entrevistados disseram não preferir que os alunos das escolas públicas recebam educação sexual em algum momento da sua trajetória escolar e $84 \%$ deles concordaram totalmente ou em parte que os professores discutissem com os alunos sobre a igualdade entre mulheres e homens. Especificamente entre o público respondente católico, 77\% concordou com tal discussão em sala de aula e entre os evangélicos, 59\%.

Tem ganhado notoriedade o uso do termo "ideologia de gênero" que, como vimos, estava presente tanto na fala do ministro da educação, como na nota da CNBB. Uma das primeiras vezes que tal expressão foi utilizada publicamente se deu em 1998 em uma Conferência Episcopal da Igreja Católica realizada no Peru intitulada "A ideologia de gênero - seus perigos e alcances". Os livros que a inspiram são Agenda de gênero (1996) de Dale O’ Leary, uma militante pró-vida ${ }^{134}$ que havia participado das Conferências da ONU de Mulheres. Em seu livro afirma que a partir desse momento histórico tal entidade assumiu a perspectiva de gênero trazida pelas feministas para pautar as políticas dos direitos das mulheres na ONU, o que via com grande preocupação. Além dele, o outro livro é o Ideologia de gênero: o gênero

\footnotetext{
${ }^{131}$ Em resolução o CNE disse que "emitirá orientações específicas sobre orientação sexual e identidade de gênero" posteriormente. Disponível em: : https://oglobo.globo.com/sociedade/educacao/conteudos-sobre-genero-sexualidade-na-basecurricular-podem-ficar-para-depois-22178446\#ixzz585eXhKu3 . Acesso em: 24 fev. 2018.

${ }^{132}$ Disponível em: http://educacao.estadao.com.br/noticias/geral,base-curricular-nao-tem-prisao-aideologia-de-genero-diz-ministro,70002127315 . Acesso em: 24 fev. 2018.

${ }^{133}$ Movimento fundado em 08 de março de 1993 por pessoas católicas e feministas. É uma Organização Não Governamental que se apoia nas práticas e teorias feministas para promover mudanças culturais e religiosas. Produzem academicamente e nas mídias, fazem advocay, dão cursos, palestras, oficinas, para saber mais: http://www.catolicasonline.org.br/ .

${ }^{134} \mathrm{Nesse}$ contexto, quer dizer contra a legalização do aborto.
} 
como ferramenta de poder (2010) de Jorge Scala, que no Brasil ganhou o seguinte título: Ideologia de gênero - o neototalitarismo e a morte da família em 2015. Esse autor apresenta os estudos de gênero desqualificando-os e apontando que são danosos para a sociedade.

A partir daí se difundiu o uso entre determinados grupos da Igreja Católica, numa justificativa de que os valores judaico-cristãos estariam sendo ameaçados pelo conceito de gênero e pelas mudanças no comportamento das mulheres. Mais à frente, difundiu-se também por grupos evangélicos, entre pastores e políticos por meio de vídeos, falas, cartilhas, que destacam a ameaça do gênero às crianças e à família. Com isso, qualquer menção aos termos "gênero", "orientação sexual", "diversidade sexual", "nome social" e "educação sexual" passaram a ser vistos como problemas.

Aos poucos vamos percebendo que tem havido uma retomada da disputa da discussão moral no que tange ao ambiente escolar brasileiro, especialmente no seu currículo. Se antes ela aparecia na luta contra a coeducação e a defesa do Ensino Religioso pela Igreja Católica em relação aos Pioneiros da Escola Nova, atualmente tal disputa se dá com a parceria de deputados evangélicos, que tem tomado a frente em tais discussões, mas não são eles, grupos teoricamente secularizados também se colocam em tal disputa. Geralmente atua-se por meio do poder legislativo na sua função de fiscalizar o Executivo. Tais atores utilizam como justificativa a necessidade de representação dos anseios da maioria da população brasileira. São retomadas a defesa do conceito tradicional de família, como vimos também anteriormente, em detrimento de uma atualização que se deu entre estudiosos e também nos movimentos sociais, especialmente o feminista e o LGBT.

\subsection{2}

\section{Ensino Religioso: ainda em disputa}

O que materializa de maneira mais direta a relação entre escola pública, religião e moralidade é certamente a inserção facultativa do Ensino Religioso. Como vimos no capítulo anterior, essa foi uma disciplina extensamente disputada no campo educacional brasileiro. O fato é que ela foi, por assim dizer, "sobrevivendo" aos diferentes momentos históricos de maneira quase ininterrupta. $\mathrm{O}$ único período em que não foi prevista nas escolas foram os 30 primeiros anos da República. Foram 
duas as últimas controvérsias que envolveram o Ensino Religioso mais recentemente: um processo no Supremo Tribunal Federal (STF) e a inserção ou não da disciplina na Base Nacional Comum Curricular.

O corte temporal para compreender o primeiro episódio é o ano de 2008, quando foi assinada a Concordata Brasil-Santa Sé. Isso numa justificativa de consolidar as relações entre os dois Estados. Um dos seus artigos ${ }^{135}$ abriu a possibilidade de interpretação do Ensino Religioso como sendo confessional. Já que o texto diz "o Ensino Religioso, católico e de outras confissões religiosas (...)”, o que também pode ser percebido a partir da lógica explicativa, a modalidade confessional como uma entre outras. Se o texto inicial da LDB detalhava como seria o Ensino Religioso de oferta obrigatória e demanda facultativa ${ }^{136}$ e foi derrubado no ano seguinte pelo Congresso, deixando a cargo dos estados brasileiros a definição curricular específica, a Concordata Brasil-Santa Sé poderia ser vista também como uma invasão da legislação federal naquilo que caberia aos sistemas de ensino estaduais estipularem.

À época, o Conselho Nacional de Juventude (CONJUVE) se manifestou de forma contrária. Outras manifestações públicas apontadas por Luiz Antônio Cunha (2009) foram a de Roseli Fischmann ${ }^{137}$ que em um texto publicado no Jornal da Ciência, da Sociedade Brasileira para o Progresso da Ciência (SBPC), afirma que caso assinada a Igreja Católica teria um status jurídico diferenciado em relação às outras religiões e formas de crer e não crer e a dificuldade da Concordata ser revertida, já que se constitui como um acordo bilateral. E também a carta enviada ao então presidente Lula, seu vice, os presidentes da Câmara, do Senado e do STF e a parlamentares evangélicos pelo pastor presidente da Catedral Presbiteriana e do

\footnotetext{
${ }^{135}$ Em seu artigo 11: “a República Federativa do Brasil, em observância ao direito de liberdade religiosa, da diversidade cultural e da pluralidade confessional do País, respeita a importância do ensino religioso em vista da formação integral da pessoa. $\$ 1^{\circ}$. O ensino religioso, católico e de outras confissões religiosas, de matrícula facultativa, constitui disciplina dos horários normais das escolas públicas de Ensino Fundamental, assegurado o respeito à diversidade cultural religiosa do Brasil, em conformidade com a Constituição e as outras leis vigentes, sem qualquer forma de discriminação" (Brasil, 2010).

${ }^{136}$ Como foi visto no capítulo anterior: 1) confessional, de acordo com a opção religiosa do aluno ou de seu responsável; 2) interconfessional, resultado de um acordo entre as diferentes entidades religiosas.

${ }^{137}$ Professora e pesquisadora da Educação da Universidade de São Paulo, possui grande vivência no espaço público relacionada ao tema do Ensino Religioso. Para saber mais: Fischmann (2006), onde faz o resumo de sua trajetória.
} 
Presbitério do Rio de Janeiro Guilermino Silva da Cunha. Afirmou a sua inconstitucionalidade especialmente no que tange ao Ensino Religioso nas escolas públicas e solicitou que o documento não fosse aprovado. Outrossim, o FONAPER, apesar de ter representantes católicos, manifestou-se contra o acordo, uma vez que historicamente defende a modalidade interconfessional. Entidades como a Associação Brasileira de Antropologia e a Sociedade Brasileira de Sociologia também se colocaram publicamente contra (Giumbelli, 2011).

A resolução foi aprovada nas duas casas legislativas em 2009 e se tornou decreto no ano seguinte, o que lhe garantiu fazer parte do ordenamento jurídico brasileiro. Segundo nos conta Cunha (2013), foi utilizado como moeda de troca de deputados evangélicos para que se também votassem a favor do Projeto de Lei Geral da Religiões ${ }^{138}$, atualmente em tramitação no Senado, o que na visão de Emerson Giumbelli (2011) demonstra, de um lado, o poder da Igreja Católica em regular a autonomia e a difusão da religião no Brasil, assuntos centrais do acordo para além da definição do Ensino Religioso Confessional. Pois tal proposta legislativa se aproxima em muito ao texto da Concordata, embora com algumas ressalvas. E de outro, corrobora o protagonismo dos evangélicos que reagiram às pretensões da Igreja Católica.

No mesmo ano, a Procuradoria Geral da União entrou como uma Ação Direta de Inconstitucionalidade (ADI) 4439 no STF pedindo a interpretação jurídica para a disciplina de Ensino Religioso de forma harmoniosa à laicidade prevista na Constituição, levando-se em conta a LDB e a então recente Concordata. Uma vez que, começava-se a realizar concursos para professores de Ensino Religioso Confessional, que receberiam salários provenientes de recursos públicos, como já tinha sido o caso do estado e da capital do Rio de Janeiro ${ }^{139}$, por exemplo.

\footnotetext{
${ }^{138} \mathrm{Com}$ um texto apoiado por organizações religiosas, especialmente as evangélicas, o PL 160/2009 previa regulamentar os dispositivos constitucionais que tratam da liberdade de crença. Buscava a isonomia em relação ao Estatuto Jurídico dado à Igreja Católica no Brasil desde a Concordata Brasil Santa Sé firmada em 2008.

${ }^{139} \mathrm{No}$ estado o concurso para professores de ensino religioso confessional foi realizado em $2003 \mathrm{e}$ teve 500 vagas: 342 para católicos, 132 para evangélicos e 26 para os demais credos. Na capital foi realizado concurso público em 2013. As vagas foram divididas entre os que dariam aula de catolicismo, protestantes/evangélicos e religiões afro. Tal divisão foi feita nos dois casos a partir de pesquisas das próprias Secretarias de Educação Estadual e Municipal. Nota-se que mesmo nessa configuração grande parte dos professores tem adotado uma perspectiva que acreditam ser interconfessional por não concordarem com a legislação tanto no estado como no município do Rio de Janeiro (Giumbelli \& Sá Carneiro, 2006; Cavalieri, 2006; Cavalieri, 2007; Zeferino; 2016).
} 
De acordo com Giumbelli, o texto da Procuradoria Geral da União se apoia em argumentos que também são utilizados no caso de defesas da retirada de símbolos religiosos de repartições públicas. E além disso, a partir de um livro de três autoras (Diniz, Linço e Carrião, 2010) que classifica o campo da implementação do Ensino Religioso nos estados brasileiros. Apenas uma das redes estaduais não adota tal disciplina em regime confessional ou interconfessional. Esse último, no entanto, é tratado como uma variante do primeiro. Pois, acredita-se que se ele ocorre a partir do acordo das diferentes religiões locais, isso não anula o controle que pode ser exercido de uma ou mais religião(ões) que possui(em) mais poder em relação as outras. Logo, o documento defende a modalidade não-confessional e solicita que se proíba o Ensino Religioso Confessional no Brasil. Giumbelli (2011), em outro texto em que ele especifica o caso do Rio Grande do Sul, fala da dificuldade de se definir o modelo não confessional, muitas vezes confundido com o interconfessional ou então denominado por diferentes termos como: supra confessional, ecumênico, inter-religioso (idem, p. 262). Assim se define o Ensino Religioso não confessional no texto da ADI 4439:

(...) em que o conteúdo programático da disciplina consiste na exposição das doutrinas, das práticas, da história e de dimensões sociais das diferentes religiões - bem como de posições não-religiosas, como o ateísmo e o agnosticismo, sem qualquer tomada de partido por parte dos educadores. Estes, por outro lado, devem ser professores regulares da rede pública de ensino, e não pessoas vinculadas às igrejas ou confissões religiosas (Ministério Público Federal, 2010, p. 3).

No caso do estado do Rio de Janeiro, por exemplo, os candidatos do concurso para professor de Ensino Religioso tiveram que apresentar, além do diploma de licenciatura em qualquer disciplina, um certificado dado pela instituição religiosa a que pertenciam, o que deu vantagem às instituições religiosas tradicionais, a começar pela Igreja Católica, que detém até hoje no Brasil o modelo do que significa religião. Numa entrevista realizada por Emerson Giumbelli e Sandra de Sá Carneiro (2004), a coordenadora de Ensino Religioso da Secretaria Estadual do Rio de Janeiro na época, declaradamente católica e indicada ao cargo pela diocese da cidade, falou da dificuldade encontrada pelas outras denominações que não fossem a católica ou as evangélicas:

Nós não tínhamos o CNPJ [Cadastro Nacional da Pessoa Jurídica] deles, não sabíamos se eram pessoas jurídicas reconhecidas. Não sabíamos o que aquela entidade estava querendo com a escola, qual era o papel dele para chegar à escola. 
Não era o professor e sim quem estava assinando por ele. A OMEB [Ordem dos Ministros Evangélicos do Brasil] já fez a inscrição no Estado, o Leste 1 (CNBB) e o Rabinado, todos já são reconhecidos pelo Estado. Mas não se tem das outras, o concurso é recente, começou tudo agora, tudo novo. Então eles, pacientemente, se submeteram a esta exigência da Secretaria, até para nos salvaguardar, e gradativamente foram trazendo as documentações (idem, p. 68).

Se pensarmos na histórica dificuldade das religiões afro-brasileiras em se registrar no Brasil, vê-se que a igualdade não era estabelecida na partida ainda nesse momento. Como colocado no primeiro capítulo a partir do olhar de Montero (2011), para que uma religião fosse aceita no Brasil, ela deveria se aproximar dos moldes tradicionais mais ligados à Igreja Católica. Possuir um "CNPJ" é um deles. Mais à frente o documento de defesa da ADI explicita:

(...) na prática, as escolas públicas brasileiras, com raras exceções, são hoje um espaço de doutrinamento religioso, onde, por vezes, os professores são representantes das igrejas, tudo financiado com recursos público (Ministério Público Federal, 2010, p. 6).

(..) na verdade, a laicidade impõe que o Estado se mantenha neutro em relação às diferentes concepções religiosas presentes na sociedade, sendo-lhe vedado tomar partido em questões de fé, bem como buscar o favorecimento ou o embaraço de quaisquer crenças, ou grupo de crenças (idem, p. 12).

Com tal ação, iniciou-se um movimento que reuniu diferentes organizações da sociedade civil intitulado "Educação e laicidade", que lançou um manifesto pedindo ao STF que aplicasse integralmente os limites constitucionais ao Ensino Religioso nas escolas públicas. Destacam as situações em que o Ensino Religioso é apresentado como disciplina obrigatória e não facultativa pelas escolas ou então quando é diluído em outras matérias numa proposta de transversalidade ${ }^{140}$. E apontam que a inserção dessa matéria na Constituição brasileira se deu naquele contexto por conta de um "lobby religioso" numa justificativa civilizatória, o que atualmente poderia ser substituída por "soluções laicas" como a que trata as Diretrizes Nacionais para a Educação em Direitos Humanos, que podem contemplar os temas da diversidade e do pluralismo religioso brasileiro. E alertam

\footnotetext{
${ }^{140}$ Como é o caso de São Paulo, por exemplo. No primeiro segmento do Ensino Fundamental o ensino religioso é abordado como um tema transversal, o que para Cunha (2009) infligiria o seu caráter facultativo previsto. Para saber mais sobre o caso desse estado ver: LUI, Janayna de Alencar. "Em nome de Deus": um estudo sobre a implementação do ensino religioso nas escolas públicas de São Paulo. Programa de Pós-Graduação em Antropologia Social da Universidade Federal de Santa Catarina, 2006.
} 
para o aumento de conflitos possíveis dentro de sala de aula e o gasto de dinheiro público com o Ensino Religioso ${ }^{141}$.

Além disso, inúmeras organizações solicitaram participar da ADI enquanto entidades com grande interesse na questão jurídica que se travava, algumas delas merecem destaque ${ }^{142}$ : CNBB, FONAPER, Conferência dos Religiosos do Brasil (CRB), Associação Nacional de Educação Católica do Brasil (ANEC), Ação Educativa, Ecos Comunicação e Sexualidade, Associação Brasileira de Ateus e Agnósticos, União dos juristas católicos do Rio de Janeiro (UJUCARJ), Associação dos juristas católicos do Rio Grande do Sul, União dos Juristas Católicos de São Paulo (UJUCASP). Umas, como a as duas primeiras, presentes em outras disputas ou então que já participaram da construção de uma política pública. Outras aparentemente novas nesse campo de disputas, pelo menos nos limites que esse trabalho pôde acompanhar, tais como as associações de juristas presentes, todas de juristas católicos.

Em março de 2015, foi realizada uma audiência pública convocada pelo STF com representantes das 31 entidades religiosas ou ligadas à Educação que solicitaram presença $^{143}$. Apenas 8 delas manifestaram-se contra o parecer apresentado pela

\footnotetext{
${ }^{141}$ Disponível em: http://www.cartaeducacao.com.br/reportagens/conservadorismo-e-religiaopautam-debate-sobre-educacao-com-secretario-de-sp/ . Acesso em: 09 mar. 2018.

${ }^{142}$ As outras: Grande Loja Maçônica do Estado do Rio de Janeiro, Conectas Direitos Humanos, Comitê Latino Americano e do Caribe para a Defesa dos Direitos da Mulher (CLADEM), Relatoria Nacional para o direito humano à educação da plataforma de direitos humanos econômicos, sociais, culturais (Plataforma DHESCA Brasil), Instituto de Biótica, Direitos Humanos e Gênero (ANIS).

${ }^{143}$ Algumas delas: Conselho Nacional de Secretários de Educação (CONSED), Confederação Nacional dos Trabalhadores em Educação (CNTE), Confederação Israelita do Brasil (CONIB), Conferência Nacional dos Bispos do Brasil (CNBB), Convenção Batista Brasileira (CBB), Federação Espírita Brasileira (FEB), Federação das Associações Muçulmanas do Brasil (FAMBRAS), Federação Nacional do Culto Afro-Brasileiro (FENACAB), Igreja Assembleia de Deus - Ministério de Belém, Convenção Nacional das Assembleias de Deus - Ministério de Madureira, Liga Humanista Secular do Brasil (LIHS), Sociedade Budista do Brasil (SBB), Ação Educativa, Instituto de Bioética, Direitos Humanos e Gênero (Anis), Associação Nacional de Advogados e Juristas Brasil-Israel (ANAJUBI), Arquidiocese do Rio de Janeiro, Associação InterReligiosa de Educação e Cultura (ASSINTEC), Centro de Raja Yoga Brahma Kumaris, Comissão Permanente de Combate às Discriminações e Preconceitos de Cor, Raça, Etnia, Religiões e Procedência Nacional, Comitê Nacional de Respeito à Diversidade Religiosa da Secretaria de Direitos Humanos da Presidência da República, Conectas Direitos Humanos, Fórum Nacional Permanente do Ensino Religioso (FONAPER), Igreja Universal do Reino de Deus, Observatório da Laicidade na Educação, deputado Marcos Feliciano, membro da Comissão de Constituição e Justiça e de Cidadania, da Comissão de Direitos Humanos e Minorias e da Frente Parlamentar Evangélica e o senador Magno Malta da Frente Parlamentar Mista Permanente em Defesa da Família. Disponível em: Disponível em:http://www.stf.jus.br/portal/cms/verNoticiaDetalhe.asp?idConteudo=293563 . Acesso em: 10 mar. 2018.
} 
Procuradoria Geral da União, isto é, defenderam a constitucionalidade do Ensino Religioso Confessional. Nota-se que, apesar de algumas lideranças evangélicas se pronunciarem a favor do Ensino Religioso enquanto disciplina optativa para o Ensino Fundamental público, essa ainda é uma pauta ostensivamente da Igreja Católica. Em tempos de mudança religiosa brasileira, tal atuação tem sido uma maneira de tentativa de manutenção da hegemonia simbólica católica no ensino, mas não mais com a força da sociedade como em tempos anteriores. Bispo Macedo da IURD, por exemplo, falou que não cabia às igrejas evangélicas atuarem para o Estado estabelecer proibições consideradas religiosas. Na sua visão, que se faz como um contraponto à da Igreja Católica, o Estado não deveria ser instado a tratar de temas como o do Ensino Religioso, por exemplo (Almeida, 2017).

No entanto, a presença de associações de juristas católicos na audiência da ADI demonstra que a elite jurídica brasileira ainda é tradicionalmente católica, quando comparada, por exemplo, com a elite política, cada vez mais não só do legislativo, como também do Executivo. Como afirma Ronaldo Almeida (2017), ainda é pequena a incidência de evangélicos no Judiciário. Se as lideranças evangélicas políticas tentam subsidiar pautas como a do Escola sem Partido, como veremos à frente, e luta contra o "gênero" e a "diversidade sexual" nos documentos de educação, embora no último caso haja também atuação da bancada católica na Câmara Federal, a defesa do Ensino Religioso é, em grande medida, do grupo católico. Sua atuação, como ocorria nos tempos passados, se dá de maneira institucional, bastante diferente da atuação dos evangélicos.

Em maio de 2016 foi lançado pelo Conselho Nacional do Ministério Público o Roteiro de atuação do Ministério Público: Estado Laico e Ensino Religioso nas escolas públicas, com o objetivo de fornecer subsídios às instâncias estaduais do Ministério Público na atuação contra as violações à Constituição pelos sistemas educacionais estaduais brasileiros. Tal documento conclui como a ADI, que à época estava em curso: apenas o Ensino Religioso não confessional facultativo harmoniza com a laicidade do Estado. Enfatiza-se a necessidade de ofertas alternativas aos alunos que optarem por não realizar tal matéria. Além disso, a defesa do Ensino Religioso que respeite e estimule o conhecimento sobre a diversidade cultural religiosa do Brasil e o direito de não crença numa abordagem que fundamente 
dimensões históricas, sociais e antropológicas e visem, no limite, combater o preconceito, o racismo e as discriminações. Para a reflexão de valores e princípios éticos, elenca-se uma abordagem que seja filosófica. Constituiu-se como um guia de ação nessa área para fomentar a discussão do Ensino Religioso e regularizá-la nos estados a partir de uma ótica comum ao Ministério Público.

No entanto, o caminho do STF foi outro. Depois de sete anos, em setembro de 2017, a ADI foi julgada improcedente, apesar de ter sido uma votação acirrada, foram seis votos contra cinco a favor. Entendeu-se que o Ensino Religioso pode ter natureza confessional - vinculado às religiões - nas escolas públicas brasileiras ${ }^{144}$. Logo, se a ADI foi apenas rejeitada e nada foi acrescentado para auxiliar o entendimento da lei, ficou-se como antes. Advogou-se que há como ensinar sobre uma religiosidade específica sem que haja proselitismo versus a perspectiva de que a única maneira de não infringir a laicidade do Estado seria pela via não confessional e sem a contratação de professores creditados pelas religiões. Discordou-se também em relação à atuação do MEC quanto ao estabelecimento de parâmetros curriculares e conteúdos mínimos para tal disciplina. $\mathrm{E}$ ainda no sentido dado à própria ideia de laicidade e neutralidade do Estado em relação à fé, como sendo a total ausência ou o reconhecimento das religiões no espaço público ${ }^{145}$.

A segunda controvérsia, que se deu mais atualmente e foi concomitante da discussão da ADI 4439, foi o "entra e sai" do conteúdo referente à disciplina de Ensino Religioso da Base Nacional Comum Curricular. Na LDB, em seu artigo 14, constam os conhecimentos e saberes que constituem a Base Nacional Comum na Educação Básica, um deles é o Ensino Religioso. E assim foi feito. Nas duas primeiras versões da Base o FONAPER teve grande atuação no grupo encarregado do Ensino Religioso, compondo a comissão de especialistas. Na sua primeira versão, a disciplina foi inserida no grupo das ciências humanas. Uma vez que buscava-se realçar o seu caráter histórico e filosófico e contribuir no estudo da diversidade cultural religiosa a partir do olhar dos direitos humanos. Além disso, diferenciava-se do Ensino Religioso ministrado até então, identificado com um viés

\footnotetext{
${ }^{144}$ Cf:http://www.stf.jus.br/portal/cms/verNoticiaDetalhe.asp?idConteudo=357099 e ainda: https://oglobo.globo.com/sociedade/educacao/stf-decide-que-escolas-publicas-podem-ter-ensinoconfessional-21878145. Acesso em: 10 mar. 2018.

${ }^{145}$ Disponível em: https://brasil.elpais.com/brasil/2017/08/31/politica/1504132332_350482.html . Acesso em: 10 mar. 2018.
} 
proselitista. A sua proposta se dizia não confessional e tinha como objeto o "conhecimento religioso"146. O seu objetivo era o de "compreender as diferentes vivencias, percepções e elaborações relacionadas ao religioso e ao não religioso" (MEC, 2016, p. 285). Desse modo, valia-se de um olhar interdisciplinar congregando abordagens e temas numa perspectiva ora sociológica, antropológica, histórica e ora geográfica, como também dos direitos humanos e da Filosofia.

A segunda versão como vimos, é que apresenta pela primeira vez a discussão de gênero na disciplina de Ensino Religioso, que foi destacado das outras ciências humanas. Buscava atentar para as produções de identidades e o respeito às diferenças de gênero, classe social, religião, raça e outras, aumentar a capacidade de leitura de mundo ${ }^{147}$. Na prática, os objetivos de aprendizagem mudam muito pouco de uma versão para outra. O Ensino Religioso foi retirado da terceira versão da Base, a legislação brasileira foi utilizada como justificativa, além de facultativo, caberia aos sistemas de ensino à sua regulamentação. Desde o início, a regulação da disciplina de Ensino Religioso dividiu opiniões.

No final de novembro de 2017, a quarta versão da BNCC foi enviada ao CNE com uma parte dedicada à regulamentação do Ensino Religioso e teve uma comissão especifica do Conselho para esse assunto, além de ter sido objeto de diversas audiências públicas ao redor do Brasil. Uma das justificativas para o seu retorno foi a decisão tomada há dois meses pelo STF, que manteve a legislação como antes ${ }^{148}$. A mesma utilizada para fundamentar a retirada da disciplina na sua terceira versão. A última exposição da Base foi entregue ao CNE para votação prevendo a inserção

\footnotetext{
${ }^{146}$ Divididos em três eixos: 1) "ser humano, considerando as corporeidades, as alteridades, as identidades, as imanência-transcendência, os valores e os limites éticos, os direitos humanos, a dignidade"; 2) "conhecimentos religiosos, considerando os mitos, os ritos, os símbolos, as ideias de divindades, as crenças, os textos sagrados orais e escritos, as filosofias de vida, as ideologias e as doutrinas religiosas"; 3) práticas religiosas e não religiosas, considerando suas manifestações nos diferentes espaços, os territórios sagrados e as territorialidades, as experiencias religiosas e não religiosas, as lideranças religiosas, o ethos, as espiritualidades, as diversidades, a política, a ecologia" (idem, p. 285).

${ }^{147}$ Dessa vez os eixos de formação eram os seguintes: Letramentos e capacidade de aprender; Leitura do mundo natural e social Ética e pensamento crítico; Solidariedade e sociabilidade. Além disso, por toda essa versão buscou-se identificar os temas integradores que dialogam com os objetivos do ensino religioso: 1) economia, educação financeira e sustentabilidade; 2) culturas indígenas e africanas; 3) culturas digitais; 4) direitos humanos e cidadania - englobando educação para o transito, idosos, questões de diversidade, gênero e sexualidade, segurança alimentar; 5) educação Ambiental (MEC, 2016, p. 318).

${ }^{148}$ Disponível em: http://educacao.estadao.com.br/noticias/geral,ensino-religioso-na-basecurricular-ainda-tera-discussao-a-parte,70002122041 . Acesso em: 09 mar. 2018.
} 
da discussão de gênero e sexualidade como um dos componentes da matéria de Ensino Religioso, como colocado acima. O documento foi aprovado no dia 15 de dezembro de $2017^{149}$ e posteriormente homologado pelo Ministério da Educação. O Ensino Religioso terminou sendo colocado como uma área específica numa perspectiva que parte das Ciência(s) da(s) Religião(ões) que investigam os fenômenos religiosos nas diferentes culturas e sociedades enquanto uma maneira humana de responder os enigmas do mundo, da vida e da morte. Especificamente em relação ao Ensino Religioso no Ensino Fundamental definiu-se:

Cabe ao Ensino Religioso tratar os conhecimentos religiosos a partir de pressupostos éticos e científicos, sem privilégio de nenhuma crença ou convicção. Isso implica abordar esses conhecimentos com base nas diversas culturas e tradições religiosas, sem desconsiderar a existência de filosofias seculares de vida (MEC, 2017, p. 434).

Objetiva problematizar os preconceitos e combater a intolerância, a discriminação e a exclusão. Seus objetivos de aprendizagem se aproximam da ética e visam à orientação de condutas individuais ${ }^{150}$. O texto, no entanto, é mais simples em relação à primeira versão da Base e também, em menor escala, da segunda. Mantém praticamente a antiga estrutura programática, apenas de forma mais direta. Dá ênfase aos princípios éticos, o que é diferente da abordagem interdisciplinar das religiões e filosofias de vida propostas pela primeira versão. Esse pode ser um reflexo da virada dada em relação ao documento como um todo a partir da mudança de governo em 2016, a BNCC aprovada foi criticada por manter um modelo conteudista, o que fere a sua proposta constitucional de "mínimo comum".

\subsection{3}

\section{Civismo, moral e ética}

A ética, atualmente um dos temas transversais e amplamente lembrada nos documentos oficiais de educação como importante para a chamada formação

\footnotetext{
${ }^{149}$ Corre na Câmara um PL, de número 4486/2016 do deputado federal Rogério Marinho (PSDB/RN) que visa que a BNCC seja aprovada pelo Congresso Nacional.

${ }^{150}$ Suas competências: "1) Conhecer os aspectos estruturantes das diferentes tradições/movimentos religiosos e filosofias de vida, a partir de pressupostos científicos, filosóficos, estéticos e éticos; 2) Compreender, valorizar e respeitar as manifestações religiosas e filosofias de vida, suas experiências e saberes, em diferentes tempos, espaços e territórios; 3) Reconhecer e cuidar de si, do outro, da coletividade e da natureza, enquanto expressão de valor da vida; 4) Conviver com a diversidade de crenças, pensamentos, convicções, modos de ser e viver; 5)Analisar as relações entre as tradições religiosas e os campos da cultura, da política, da economia, da saúde, da ciência, da tecnologia e do meio ambiente; Debater, problematizar e posicionar-se frente aos discursos e práticas de intolerância, discriminação e violência de cunho religioso, de modo a assegurar os direitos humanos no constante exercício da cidadania e da cultura de paz" (idem, p. 435).
} 
cidadã, é outro dos temas imprescindíveis para pensarmos a interface entre religião, moralidade e escola. Luiz Antônio Cunha (2009) esclarece que a ética entrou para os currículos brasileiros com o nome de moral para substituir a religião. Só em 1993, que foi revogada a lei de 1969 que tratava da obrigatoriedade da então disciplina Moral e Cívica tão representativa do período da Ditadura Militar. Até aí ela permaneceu como um "enxerto curricular", nos dizeres do autor. No entanto, seus defensores ainda existem e tem inspirado vários projetos de lei que visam à reintrodução da disciplina com diferentes nomes ou combinação deles - Moral, Civismo, Cidadania, Ética, Direitos e Deveres - mas muito próximas em seus objetivos e conteúdos.

Daniela Patti do Amaral (2007) fez uma pesquisa sobre tais projetos entre os anos de 1997 e 2006. Encontrou 13 proposições que se dividiram entre o Senado e a Câmara Federal, sendo uma delas de um deputado pastor ${ }^{151}$. A justificativa em geral era a de que com tal disciplina se resgataria os valores perdidos pela sociedade e tal constatação era um consenso manifestado pela maioria das pessoas. Acreditam que a ética abordada como um tema transversal não seria suficiente, daí as proposições. As disciplinas que propõem o ensino da Ética, da Cidadania e da Moral e Cívica confrontam, na visão dos políticos que as encampam, os modelos inadequados veiculados principalmente pelos programas de televisão. Além disso, oferecem respostas ao crescimento do envolvimento dos jovens com as drogas e o tráfico e das adolescentes grávidas, à falta de respeito e aos desvios de comportamento dos jovens, segundo constam os projetos (Amaral, p. 2007, p. 367 e 368).

Entre o período de 2007 e 2017 foram encontrados ao todo 44 Projetos de Lei nas duas Casas Legislativas, 37 na Câmara e 7 no Senado Federal, o que são em média 4 projetos propostos por ano e representam um grande aumento em relação à década

\footnotetext{
${ }^{151}$ O Projeto de Lei n. 772 de 2003 proposto pelo deputado Pastor Frankerbergen (PTB/RO) de Roraima. Exemplo que resume muito bem as propostas por conter todos os elementos que aparecem nelas combinados: “(...) voltado ao resgate e à consolidação dos valores morais, patrióticos e sociais, através de todas as atividades escolares, inclusive quanto ao desenvolvimento de hábitos democráticos, movimentos de juventude, estudos de problemas brasileiros, atos cívicos, promoções extraclasse e orientação dos pais (...) a difusão de valores fundamentais ao interesse social, aos direitos e deveres dos cidadãos, de respeito ao bem comum e à ordem democrática, através da preservação do espírito religioso, da dignidade da pessoa humana e do amor à liberdade com responsabilidade, sob a inspiração de Deus" (idem, p. 358).
} 
anterior $^{152}$. Tais PLs foram agregados em pelo menos dois projetos diferentes ao longo dos 10 anos. Mais uma vez os nomes das disciplinas variam: "Ética e Cidadania", "Cidadania", "Educação Cívica", "Educação, Moral e Cívica", “Organização Social e Política do Brasil”, "Valores Éticos e de Cidadania” entre outros. Além disso, acrescenta-se em alguns casos noções de Direito ${ }^{153}$, "Ética Social e Política", "Direitos e Deveres". Algumas das justificativas foram a "formação do caráter" "com apoio na moral, na dedicação à família e à comunidade", o aumento da corrupção, a possibilidade de construção nos jovens de uma postura ética no dia a dia e na atividade política. Ou mesmo a ideia do "caos" generalizado, por conta das drogas e do álcool, da violência e dos acidentes de trânsito, inclusive causados pelos próprios jovens, da "falta de humanidade", “do desrespeito ao patrimônio público e ao próximo", da "falta ou perda dos valores éticos universais fundamentais", justificativas bem parecidas com as encontradas por Amaral. Ainda para preencher o vazio deixado pela exclusão das antigas disciplinas Educação Moral e Cívica e Organização Social e Política do Brasil.

Uma novidade em relação à década anterior é a ressalva que aparece em alguns dos PLs: fala-se de uma atenção em isentar tais disciplinas "de ideologias", que elas sejam "o mais imparcial possível” para que o pensamento político se construa a partir da própria consciência do educando, o que pode ser uma explicação para o diferencial do acréscimo do ensino dos "direitos e deveres", das atribuições dos parlamentares e o funcionamento dos três poderes, às vezes do Sistema Nacional de Segurança. Indicam uma percepção sobre a cidadania como o conhecimento das leis brasileiras, ser cidadão é ter o conhecimento das leis que regem o Brasil e atuar como fiscais dos representantes eleitos. Acrescenta-se que com isso, contribui-se também para a construção do "espírito nacionalista e patriótico", por meio de

\footnotetext{
${ }^{152}$ Um Projeto de Lei que pode ser destacado como exemplo representativo é o PL 4838/2012, proposto pelo deputado Eliseu Padilha (PMDB/RS) da inserção de da disciplina Ética e Cidadania no Ensino Fundamental e médio e também como optativa no ensino superior. Tem nas suas justificativas: "Grande parte dos problemas que afligem os brasileiros no séc. XXI estão relacionados à falta ou a perda dos valores éticos universais fundamentais, para um convívio social saudável e promissor. O egoísmo, o individualismo exacerbado, a ganância desmedida, a injustiça, o caos urbano, a miséria social, a violência nas cidades e no trânsito, a corrupção, entre tantos outros problemas que assolam o nosso cotidiano, reflete a falta de uma constelação de valores éticos indispensáveis à vida em sociedade e responsáveis por conter as paixões individuais e fazer prevalecer o bem comum" (Padilha, 2012).

${ }^{153}$ Tais como: constitucional, administrativo, do consumidor, das crianças e dos Adolescentes ou de forma genérica "leis brasileiras".
} 
conteúdos que abarquem as datas e símbolos cívicos - hinos nacional e da Bandeira, por exemplo.

Por outro lado, a ideia de ética se cola muito à percepção de uma "boa conduta, honestidade", "visão mais crítica" da realidade, "rigor no combate à corrupção". E ainda com isso, aumentaria a responsabilização dos jovens pelos seus atos, uma vez que saberiam as consequências deles e não entrariam e conflito com a lei. As propostas direcionam-se para todas as etapas de ensino, mas principalmente para o segundo segmento do Ensino Fundamental e o Médio, especialmente o ensino público. Os adolescentes e jovens são vistos como futuros trabalhadores, futuros eleitores, responsáveis pelos seus atos que vão desde a possibilidade de entrada no tráfico, o uso de drogas e álcool, o envolvimento com acidentes de trânsito, ainda a percepção deles como sendo desinteressados em matéria de política e participação social, daí as proposições.

Os conceitos de ética, moral, civismo e cidadania, como vimos, têm sido extensamente disputados. De um lado estão aqueles que, como anteriormente se pautava a Igreja Católica na "crise dos valores", defendem uma perspectiva de ensino de um determinado tipo de comportamento na sociedade, ligado à ordem, à disciplina e à manutenção do status quo, que podem se relacionar mais ou menos às visões religiosas dos legisladores. De outro, há uma disputa de tais conceitos a partir de uma perspectiva da Democracia, significando não só o cumprimento dos direitos, como também o incentivo, especialmente dos jovens, à participação ativa na sociedade, começando inclusive pela escola. A passagem de uma ética e moral religiosas para seus correlatos democráticos não é dada e ainda está em curso na medida em que a sociedade brasileira se seculariza.

\subsection{4}

\section{Escola sem Partido: entre conservadores e religiosos}

Ganhou destaque nos últimos anos o movimento Escola sem Partido (ESP), que se traduziu em diversas proposições legislativas ao redor do Brasil em Assembleias Legislativas e Câmaras de Vereadores, e também no Senado e na Câmara Federal. Esse é um movimento fundado por um procurador de Justiça de São Paulo, Miguel 
$\mathrm{Nagib}^{154}$, que existe desde 2004 e só mais recentemente cresceu em adeptos a apoiadores dentre políticos e pessoas da sociedade civil ${ }^{155}$, especialmente a partir da discussão que envolvia o tema gênero aqui explicitada nos planos de educação e também durante as manifestações a favor e contra o processo de impeachment da presidente Dilma Roussef. O autor que se declara como católico teve a ideia de criar um movimento quando sua filha um dia chegou da escola dizendo que o seu professor de História tinha comparado Che Guevara com São Francisco de Assis. Para Nagib, "as pessoas que querem fazer a cabeça das crianças associam as duas coisas e acabam dizendo que Che Guevara é um santo" 156 que à época escreveu uma carta aberta ao professor e passou a distribuí-la no estacionamento da escola da filha, que acabou não surtindo efeito, mas o impulsionou a criar uma associação, inspirado num site norte-americano que reunia denúncias de "doutrinação" nas escolas realizadas por professores.

Prevê "deveres do professor", tais como o de "não se aproveitar da audiência cativa dos alunos para promover os seus próprios interesses, opiniões, concepções, preferências ideológicas, religiosas, morais, políticas e partidárias" ou ainda "o professor respeitará o direito dos pais a que seus filhos recebam a educação moral que esteja de acordo com suas próprias convicções" (Escola sem Partido) ${ }^{157}$. Possui como alguns dos seus argumentos a "neutralidade religiosa do Estado" e a "liberdade de crença" e busca coibir o que chama de "doutrinação" realizada por professores dentro das quatro paredes das salas de aula. Em contrapartida, foi apelidado pelos professores de "lei da mordaça" e foram criados vários movimentos, o que ganhou mais notoriedade foi o movimento de Professores Contra o Escola sem Partido ${ }^{158}$, que passou a atuar por meio de sites, debates e

\footnotetext{
${ }^{154}$ No site do Programa esse é o único nome que aparece e em todas as audiências públicas consultadas é ele o único porta-voz do movimento.

${ }^{155} \mathrm{De}$ acordo com o mapa colaborativo lançado pelo movimento Professores Contra o Escola sem Partido, existiam em 04 de março de 2018, 143 projetos de lei tramitando ou aprovados em todo o Brasil que se inspiram no Escola sem Partido de alguma forma - ou são "tipo" Escola sem Partido, ou restringem ou proíbem a discussão de gênero nas escolas, ou ainda criminalizam o "assédio ideológico. 12 em âmbito federal, 25 em âmbito estadual e 106 em municípios. Disponível em: https://www.google.com/maps/d/u/0/viewer?mid=1 AbaBXuKECclTMMYcvHcRphfrK9E\&ll=15.800615699999982\%2C-47.863225899999975\&z=8 . Acesso em: 04 mar. 2018.

${ }^{156}$ Disponível em: https://brasil.elpais.com/brasil/2016/06/23/politica/1466654550_367696.html . Acesso em: 04 mar. 2018.

${ }^{157}$ Disponível em: http://www.programaescolasempartido.org/. Acesso em: 04 mar. 2018.

${ }^{158}$ Iniciado como uma página no facebook e hoje atua como um movimento, define-se como "um grupo de estudantes e professores que se opõem aos projetos de lei incentivados por este movimento [ESP] que tramitam em várias casas legislativas do país. Para combater este retrocesso buscamos na
} 
publicações contra tal proposta. Além disso, coletando informações de professores ao redor do Brasil em relação às suas formas de resistência e oposição em sala de aula e fora dela. Mais recentemente, esse grupo se aproximou da "Frente Gaúcha Escola sem Mordaça" "159 e criou o Movimento Educação Democrática (MDE), que tem uma proposta de articulação nacional de grupos já existentes e de criar uma agenda propositiva para a educação, para além do contraponto ao Escola sem Partido $^{160}$.

O primeiro estado a ter o seu Projeto de Lei aprovado foi Alagoas ainda em $2015^{161}$.

Tal PL colocou educadores, sindicato dos trabalhadores da educação e intelectuais em contraponto a religiosos e adeptos do Movimento Brasil Livre (MBL) ${ }^{162}$ naquele estado. Foi julgado inconstitucional pelo Supremo Tribunal Federal (STF) em 2017. Interessante notar algumas falas lado a lado, um cientista social, professor da Universidade Federal de Alagoas (UFAL):

Alagoas tem os piores indicativos do país, e a Assembleia acha que vai resolver o problema assim? (...) O estado tem a taxa mais alta de crimes contra homossexuais do país, como não discutir isso em sala de aula? Como não discutir também a religião, se Alagoas é um dos estados com maior número de manifestações de matriz africana? ${ }^{163}$

página e neste blog informar e produzir conteúdo de análise e reflexão sobre o crescimento e organização do ESP, visando fundamentar nossos argumentos para desconstruir o apoio que eles conquistaram nos anos" uara saber mais: https://professorescontraoescolasempartido.wordpress.com/ .

${ }^{159}$ Definem-se como: "A Frente Gaúcha Escola sem Mordaça, composta por entidades representativas de educadores, estudantes, profissionais atuantes na educação superior, cultura, pesquisa, comunicação, direito, ações comunitárias e pelos movimentos sociais, constitui-se como um espaço coletivo suprapartidário e plural, que visa promover debates e manifestações, em defesa da Democracia e da justiça social, sobretudo no que diz respeito à Educação". Para saber mais: https://www.facebook.com/frentegauchaescolasemmordaca/ .

${ }^{160}$ Definem-se como: “A associação foi criada para reunir pessoas de todo Brasil e articular grupos na mobilização por uma educação democrática e pela escola pública”. Para saber mais: https://www.facebook.com/pg/moveducacaodemocratica/about/?ref=page_internal .

${ }^{161}$ Batizado de "Escola Livre", o Projeto de Lei 7800/2016 teve autoria do deputado estadual Ricardo Nezinho (PMDB). Além dele, outros 15 projetos de lei municipais foram também aprovados, entre propostas inspiradas no ESP e/ou que tratavam da restrição ou proibição da discussão de gênero nas escolas de acordo com o mapa colaborativo já citado, mas não serão discutidos aqui, uma vez que os projetos são muito parecidos. Segundo reportagem do Nexo Jornal, o município de Santa Cruz do Monte Castelo, no norte do Paraná o projeto foi aprovado e passou a vigorar em 2015. Teve cartazes pregados nas paredes das salas de aulas. Disponível em: https://www.nexojornal.com.br/expresso/2017/09/05/O-que-aconteceu-com-as-propostas-da-

Escola-sem-Partido-pelo-Brasil . Acesso em: 05 mar. 2018.

${ }^{162}$ Define-se em sua página no Facebook como "O Movimento Brasil Livre é uma entidade que visa mobilizar cidadãos em favor de uma sociedade mais livre, justa e próspera". Tem ganhado muito espaço em todo o Brasil principalmente a partir da campanha de Impeachment de Dilma Roussef em 2016 e especialmente entre os jovens. Para saber mais: http://mbl.org.br/ .

${ }^{163}$ Disponível em: http://g1.globo.com/al/alagoas/noticia/2016/04/entenda-o-que-o-projeto-escolalivre-muda-no-ensino-estadual-em-alagoas.html . Acesso em: 05 mar. 2018. 
E a constatação do arcebispo de Maceió:

Estamos lutando favoravelmente aqui em Maceió desde quando o plano diretor entrou em discussão na Câmara de Vereadores. O Escola Livre vem ajudar na formatação do que a Igreja pensa de como deve ser a educação nas escolas de Alagoas (idem).

Em geral os projetos de lei propostos nos três níveis - federal, estadual e municipal - são muito parecidos. Já que o movimento Escola sem Partido disponibiliza modelos de projetos de lei e de decretos, além de um parecer de constitucionalidade de autoria de Nagib e fontes normativas a serem consultadas que em tese suportam a causa pretendida. Desse modo, faz-se jus a um olhar mais acurado nas propostas legislativas em nível federal, especialmente as que se encontram na Câmara dos Deputados. Uma vez que o PL do Senado, de número 193/2016, de autoria do Senador Magno Malta (PR/ES), foi retirado em novembro de 2017 pelo próprio autor. Isso teria ocorrido como um pedido do próprio movimento, uma vez que foi percebido que o projeto teria mais chance da passar na Câmara que no Senado e assim seguiria direto para o plenário ${ }^{164}$.

É de 2015 o Projeto de Lei 867 proposto na Câmara dos Deputados pelo Deputado Izalci (PSDB/DF), membro da bancada evangélica, que busca instituir o Programa Escola sem Partido, atualmente apensado ao projeto 7180 de 2014, que aguarda parecer do relator da comissão especial instaurada em maio de 2016. O PL proíbe a "doutrinação política e ideológica" de professores e gestores em relação aos seus alunos e solicita aos docentes que não façam propaganda religiosa, ideológica ou político-partidária e nem favoreçam ou prejudiquem os alunos por conta de suas convicções e apresente as principais "versões, teorias, opiniões e perspectivas" ao falar sobre questões políticas e socioculturais. Pauta-se, entre outras coisas, na liberdade de aprender e na liberdade de consciência e de crença dos alunos e no direito deles em sabê-lo. Reconhece a "vulnerabilidade do educando como parte mais fraca da relação de aprendizado". E afirma o direito dos pais para que os seus filhos recebam a educação moral de acordo com as convicções dos primeiros. Prevê ainda que as Secretarias de Educação e o Ministério Público recebam reclamações quando houver descumprimento. Como justificativa, o texto do projeto traz a

\footnotetext{
${ }^{164}$ Disponível em: https://oglobo.globo.com/sociedade/magno-malta-retira-de-tramitacao-nosenado-projeto-do-escola-sem-partido-22092617 . Acesso em: 05 mar. 2018.
} 
percepção de que professores e autores de livros didáticos ${ }^{165}$ tem favorecido suas "correntes políticas e ideológicas" a fim de que os alunos adotem "padrões de julgamento e de conduta moral - especialmente moral sexual - incompatíveis com os que lhes são ensinados por seus pais ou responsáveis".

Um dos argumentos utilizado é a citação da Convenção Americana sobre Direitos Humanos de 1969, mais conhecida como Pacto de San José, que em seu $12^{\circ}$ artigo prevê que os pais ou tutores têm o direito de que os seus filhos recebam a educação religiosa e moral de acordo com as suas próprias convicções. Essa é uma carta internacional feita num contexto de ditaduras na América Latina, dessa forma, seu objetivo principal, como esclarece Fernando de Araujo Penna (2017), foi o de proteger o indivíduo, a família, o espaço privado contra as intervenções indevidas especialmente do Estado. Nesse caso, mães, pais e responsáveis possuem o direito de educar seus filhos de acordo com os seus próprios valores no âmbito privado. A escola pública é compreendida pelo Programa, a partir das vontades privadas. Outras cartas como o $\mathrm{ECA}^{166}$, a $\mathrm{LDB}^{167}$ e a própria Constituição Federal ${ }^{168}$ são extensamente referidos. Além disso, retoma-se à laicidade do Estado - entendida como manter-se neutro em relação a todas as religiões - para defender que não se pode promover uma determinada moralidade, a partir de uma percepção do legislador de que "a moral é em regra inseparável da religião".

\footnotetext{
${ }^{165} \mathrm{Um}$ blog que ficou muito famoso entre adeptos do Escola sem Partido, especialmente pais, mães e responsáveis de estudantes, foi o "De olho no Livro Didático" que busca falar sobre "políticas educacionais e ocorrências de doutrinação nos materiais didáticos, literários e pedagógicos". Para saber mais: http://deolhonolivrodidatico.blogspot.com.br/ . Um exemplo que nos é caro é a matéria que fala sobre "doutrinação" de alunos no Candomblé e na Umbanda por livros didáticos aprovados pelo MEC para o triênio 2016/18. Ou ainda o modelo de notificação extrajudicial que pode ser utilizado para processar professores que ensinem sobre a "ideologia de gênero" feitos pelos procuradores Guilherme Schelb e Miguel Nagib do Escola sem Partido e disponibilizados no site.

${ }^{166} \mathrm{Seu}$ artigo $5^{\circ}$ onde se lê que "nenhuma criança ou adolescente será objeto de qualquer forma de exploração" e seu $53^{\circ}$ artigo que fala sobre o direito das crianças e adolescentes em ser respeitados pelos seus educadores.

${ }^{167}$ Seu $2^{\circ}$ artigo que coloca como uma das finalidades da educação o preparo do educando para o exercício da cidadania.

168“"o princípio constitucional da impessoalidade" da Administração pública; a "neutralidade política e ideológica", da "isonomia" do Estado e do "pluralismo político e de ideias"; o artigo $5^{\circ} \mathrm{em}$ seu VI inciso que trata da inviolabilidade da liberdade de consciência e de crença e o artigo 19, inciso I que veda ao Estado estabelecer cultos religiosos ou igrejas, subvencioná-los, impedir o seu funcionamento ou mesmo manter relações de dependência ou aliança, salvo em casos de interesse público, de acordo com site do Programa. Todavia, o artigo $1^{\circ}$ da Constituição de 1988 apenas fala em pluralismo político, não há menção à neutralidade política e ideológica do Estado. Um dos compromissos da Constituição é que as diferentes correntes ideológicas podem conviver harmoniosamente.
} 
Nesse momento há na Câmara sete Projetos de Lei agregados: o 7181/2014, o já citado 867/2015, o 1859/2015, о 5487/2016, o 6005/2016, o 8933/2017 e o principal e mais antigo ao qual todos os outros se vinculam, o 7180/2014. Juntos eles formam um "pacote" de projetos de lei inspirados no Escola sem Partido, para reforçá-lo em determinados pontos ou então contrapô-lo. Esse último foi proposto pelo deputado Erivelton Santana (PSC/BA), pertencente à bancada evangélica e versa sobre a "precedência aos valores de ordem familiar sobre a educação escolar nos aspectos relacionados à educação moral, sexual e religiosa". Mais uma vez é citada a Convenção Americana sobre Direitos Humanos de 1969 como justificativa. Para o legislador, as convicções pessoais e valores familiares - tidos como privados - são superiores ao currículo escolar e ao trabalho pedagógico - públicos. O PL 7181 é de autoria do mesmo deputado e busca instituir os parâmetros curriculares nacionais numa vigência decenal reforçando a defesa dos respeitos das convicções dos alunos e dos seus pais e/ou responsáveis em detrimento da educação escolar no que tange à educação moral, sexual e religiosa. O PL 1859/2015, assinado por nove deputados ${ }^{169}$, alguns deles da frente parlamentar evangélica, propõe acrescentar no $3^{\circ}$ artigo da LDB o seguinte parágrafo:

A educação não desenvolverá políticas de ensino, nem adotará currículo escolar, disciplinas obrigatórias, ou mesmo de forma complementar ou facultativa, que tendam a aplicar a ideologia de gênero, o termo 'gênero' ou 'orientação sexual (PL 1859/2015).

Justifica-se por ser a família a "base da sociedade" que o Estado deve proteger a partir das garantias constitucionais. Indica o privilégio da instituição familiar na educação e o paradoxo de "um sistema educacional concebido com o objetivo especifico de destruir a própria família como instituição". Isso por meio de uma das "ameaças mais graves à família": a criação do conceito de "identidade de gênero" e de "orientação sexual". Cita-se como exemplo o texto do Plano Nacional de Educação (PNE) de 2014, aqui já explicitado, que foi rejeitado pelo Congresso Nacional por especificar em diferentes momentos a promoção da diversidade e igualdade de gênero e o combate aos preconceitos relacionados ao gênero e à orientação sexual, dentre outros. Ainda, são apresentados autores como Judith

\footnotetext{
${ }^{169}$ São eles: Alan Rick (PRB/AC), Antonio Carlos Mendes Thame (PSDB/SP), Antonio Imbassahy (PSDB/BA), Bonifácio de Andrada (PSDB/MG), Celso Russomanno (PRB/SP), Eduardo Cury (PSDB/SP), Izalci (PSDB/DF), Givaldo Carimbão (PROS/AL) e João Campos (PSDB/GO).
} 
Butler, Karl Marx, Friedrich Engels e Kate Millet, além de Conferências da ONU e algumas ONGs para concluir que

o que verdadeiramente está acontecendo é que o conceito de 'gênero' está sendo utilizado para promover uma revolução cultural sexual de orientação neo-marxista com o objetivo de extinguir da textura social a instituição familiar (idem).

E que, ao fim e ao cabo, num mundo de completa igualdade não haverá mais “opressão de gênero" e também a existência das famílias, o que faria com que a educação se tornasse tarefa exclusiva do Estado: "todos teriam que ser educados como bissexuais e a masculinidade e a feminilidade deixariam de ser naturais" (idem).

O PL 5487/2016 proposto pelo deputado Professor Victório Galli (PSC/MT) explicita sobre a proibição de orientação e distribuição de livros às escolas públicas que falem sobre "orientação de diversidade sexual para crianças e adolescentes". Já o Projeto de Lei de número 6005/2016, proposto pelo deputado Jean Wyllys (PSOL/RJ), apresenta o programa "Escola livre", que se constitui como uma "resposta" ao ESP contrapondo-se a todos os seus preceitos. Fala da construção de uma "escola para a democracia" em que se valorize a pluralidade de ideias, o debate, a análise crítica, a não discriminação, o respeito às crenças e as não crenças e à laicidade. Por último, reforçando os cinco primeiros projetos de lei, o 8933/2017, de autoria do deputado federal Pastor Eurico (PHS/PE) busca instituir que o ensino sobre educação sexual deva ser realizado apenas mediante à autorização dos pais ou responsáveis dos alunos. Justifica-se a partir da percepção da desvalorização de "valores humanos básicos, principalmente aqueles relacionados à família”. E também a interpretação do que se tem apresentado como educação sexual nas escolas pelos últimos governos tem sido uma "distorção, quando não uma completa negação, do plano que a maioria das famílias brasileiras cristãs entende como correto para a sexualidade humana". Coloca a escola como tendo uma função "subsidiária" na educação das novas gerações e

Posicionamo-nos, dessa forma, ao lado da família. Buscamos deixar claro que educação sexual se trata em casa, com os pais, que conhecem a sensibilidade e particularidade de seus filhos. A educação moral é da família - e a escola, bem como a sociedade, deve perceber esse limite (PL 8933/2017).

Em resumo, o que está em jogo é a disputa sobre a precedência dos deveres do Estado em relação à educação escolar e aí se entende a composição de currículos - 
seus parâmetros, diretrizes e bases -, a construção dos projetos políticos pedagógicos das escolas, a relação professor-aluno ou os deveres e direitos dos pais e/ou responsáveis dos estudantes no que tange mais especificamente à educação moral, sexual e religiosa. A quem cabe o quê? Quase nada se fala dos direitos dos próprios estudantes, isto é, crianças, adolescentes e jovens.

Entre 2015 e 2017 foram realizadas 22 audiências públicas na Câmara dos Deputados, que envolveram direta ou indiretamente o assunto "Escola sem Partido". Ocorreram audiências públicas sobre a parcialidade dos livros didáticos aprovados pelo MEC, sobre "doutrinação ideológica", "assédio ideológico" praticado por professores, introdução do tema de gênero e orientação sexual nas escolas e sua retirada da Base Nacional Comum Curricular, liberdade de opinião de ministro religioso e professor ${ }^{170}$, também muitas audiências, a grande maioria delas, especificamente para debater o Escola sem Partido. Foram convidadas pessoas de diferentes espaços, desde professores universitários a representantes de movimentos da sociedade civil e entidades do terceiro setor ${ }^{171}$ e do próprio Ministério da Educação e do Fórum Nacional de Educação (FNE), deputados, vereadores, estudantes e professores da educação básica, jornalistas e advogados. Houve ainda debates em algumas capitais e uma reunião da comissão com o MBL para entrega de documentos. Além do tema ter sido lembrado em outras ocasiões como no Seminário sobre a população LGBT no Congresso e numa audiência pública da Comissão de Defesa dos Direitos da Mulher.

De um lado, entre os adeptos do ESP, um dos aspectos centrais é o enfoque dado aos direitos dos pais em relação à educação moral, sexual e religiosa dos filhos. Além disso, afirmam que querem restabelecer os direitos dos estudantes, daí a proposição de que se afixem os cartazes nas salas de aulas. Acredita-se na parcialidade de livros didáticos e de professores, na autoridade que possuem para

\footnotetext{
${ }^{170}$ O PL 6314/05 do deputado Takayana (MDB/PR) que propõe a alteração do Código Penal para excluir os crimes de injúria e difamação quando se tratar de opinião de professor e ministro religioso. ${ }^{171}$ Como por exemplo a própria associação Escola sem Partido, presente como convidado em grande parte das audiências, o Movimento dos Professores Contra o Escola sem Partido, a União Brasileira de Estudantes Secundaristas (UBES), a União Brasileira dos Estudantes (UNE), a Associação Nacional Pró-Vida e Pró-Família, a Confederação Nacional dos Trabalhadores em Educação, a União Nacional dos Dirigentes Municipais de Educação (UNDIME), a Campanha Nacional pelo Direito à Educação, o Fórum Nacional Permanente de Ensino Religioso (FONAPER) ,Todos pela Educação, o Conselho Nacional de Igrejas Cristãs do Brasil e a Ação Educativa.
} 
influenciar, estimular, incutir e impor aos alunos aquilo que pensam. A isso se chamaria "doutrinação", "lavagem cerebral", "propaganda político-partidária", algumas das expressões utilizadas nas audiências. A educação de valores e moral são entendidas como pertencentes apenas ao âmbito privado, dessa forma esse não seria papel dos professores. Uma vez que assim se faria uso político e ideológico da sala de aula, o que muitas vezes acaba sendo priorizado em detrimento dos conteúdos programáticos oficiais. Em contraponto, o Estado brasileiro estaria privilegiando a defesa de agendas que vão de encontro à proteção da família e à "moralidade cristã". Daí a necessidade de se limitar o que os professores podem ou não falar em sala de aula. Critica-se ainda o modo como a cultura afro-brasileira é ensinada nas escolas, tendo as religiões com essa origem privilégio por serem tratadas como elementos da cultura, vantagem que outras religiões não possuem no currículo. E ainda que a proposta do Projeto não deve ser confundida como tendo motivações religiosas, essa foi uma das falas do relator da comissão especial, o deputado Flavinho (PSB/SP) em uma das audiências públicas:

Desde a primeira audiência pública que nós tivemos, sempre se levanta a questão religiosa, só que não é disso que esta comissão trata. Esta comissão analisa seis projetos de lei que visam proteger os direitos dos educandos (Deputado Flavinho, audiência pública de 15 de fevereiro de 2017) ${ }^{172}$.

De outro lado, entre os que se colocam de forma contrária, acredita-se no papel da escola como contribuinte na diminuição de preconceitos e discriminações especialmente dos grupos minoritários e, por conseguinte, na construção do respeito às diversidades. Isso pode ser feito ao se abordar determinados assuntos em sala de aula. Para além disso, percebem que alguns deles podem aparecer inclusive no currículo oficial e faz diferença o enfoque a ser dado, como no exemplo trazido por Thays Oliveira, diretora da União Brasileira dos Estudantes Secundaristas (UBES) em uma das audiências, a questão da escravidão e sua relação com o racismo e também as religiões afro-brasileiras ${ }^{173}$. A escola aparece como o espaço do confronto de ideias e de convivência das diferenças. Reiteradamente, afirma-se que existem outros temas mais urgentes para a agenda educacional e que a discussão

\footnotetext{
${ }^{172}$ Disponível em: http://www2.camara.leg.br/camaranoticias/noticias/EDUCACAO-ECULTURA/523211-RELATOR-DO-ESCOLA-SEM-PARTIDO-DIZ-QUE-PROPOSTA-NAOTEM-MOTIVACAO-RELIGIOSA.html. Acesso em: 07 mar. 2018.

${ }^{173}$ Disponível em: http://www2.camara.leg.br/camaranoticias/noticias/EDUCACAO-ECULTURA/522852-PROJETO-SOBRE-ESCOLA-SEM-PARTIDO-DIVIDE-OPINIOES-DEDEBATEDORES.html . Acesso em: 07 mar. 2018.
} 
trazida pelo Escola sem Partido não é um problema da educação no Brasil. As práticas abusivas dos professores já possuem previsão de punições. Lembra-se dos recentes movimentos dos estudantes pela melhoria da educação, as ocupações estudantis. Interessante notar que numa das audiências públicas a secretaria geral do Conselho Nacional de Igrejas Cristãs do Brasil, a pastora Romi Benke, colocouse contra a proposta, dizendo que o real objetivo do Escola sem Partido era o de suprimir ideias divergentes e o debate sobre questões sociais e de gênero no ambiente escolar.

\section{3}

\section{A reforma moral e a mudança na cultura escolar}

Por meio do elenco das duas dimensões escolhidas de análise e do mapa das disputas que é montado a partir daí, vê-se a multiplicidade de atores e pontos que estão em jogo quando se relacionam escola pública, religiões e moralidades. São apresentados diversos aspectos da vida social e individual, que podem ser vistos a partir da ótica de diferentes morais seculares ou religiosas e também a partir das lutas políticas de variados movimentos sociais e de garantias de direitos requeridos por distintos grupos da sociedade, isto é, igrejas, parlamentares, partidos, minorias religiosas e/ou políticas, famílias, associações, movimentos da sociedade civil, entidades corporativas, instâncias estatais etc. Todas afirmam estar pensando no que acreditam ser o melhor em matéria educativa para as crianças e adolescentes enquanto estudantes, embora possuam muitas vezes visões concorrentes. É inegável a importância da virada de atuação pública dos parlamentares evangélicos que, por meio das disputas morais no currículo e na defesa do controle da atuação de professores, acabam por chamar atenção para o debate da escola pública. Vai-se aos poucos tornando a educação uma agenda em disputa.

No "chão da escola" a realidade já não é de hegemonia católica. Apresenta-se um novo público, como vimos os estudantes evangélicos se destacam. Entre professores e alunos são ensinados diferentes valores, o que também aparece nas definições de currículo: civilizacional, com distintas moralidades e éticas, ligados à Democracia, à sociedade de mercado, a religião pode aparecer como um dos aspectos. A maior ou menor presença de elementos religiosos em sala de aula depende muito do professor e/ou do gestor da instituição. Um outro desafio é o do 
ensino da História e da cultura afro-brasileira nas escolas públicas. Os elementos afro são associados às religiões afro-brasileiras e permanecem sendo demonizados, muitas vezes vistos nas escolas como meras brincadeiras, é daí que vem a correlação entre racismo e intolerância religiosa. Por isso é tão importante a atuação de ações internas às denominações, tais como os movimentos evangélicos e também católicos negros no sentido de relativizar tal identidade. Uma vez que crianças e adolescentes candomblecistas e umbandistas ainda são os que mais sofrem casos de intolerância religiosa.

Com o protagonismo dos evangélicos, ganha espaço novamente discussões de cunho moral e familiar no espaço público. A narrativa da "crise dos valores" introduzida na primeira metade do século XX no Brasil pela Igreja Católica, numa tentativa de conter a modernização na sociedade brasileira é atualizada. A chamada “ideologia de gênero", por exemplo, tem sido associada por grupos religiosos e/ou conservadores à destruição das famílias e interferências na orientação sexual dos jovens. Existe uma sobreposição de forças que se aliam no presente: conservadores, tradicionais e religiosos católicos e evangélicos e também não religiosos que, numa retórica de inúmeras crises - econômica, política, educacional - acabam encontrando terreno fértil ${ }^{174}$. Como atenta Ronaldo Almeida (2017), falamos de um conjunto relativamente variado de discursos, valores, ações e posicionamentos políticos que possuem interesses parciais e conjunturalmente comuns.

A nuance observada por esse autor da atuação dos evangélicos pentecostais é a disputa por uma "moralidade pública" (Casanova, 1994 apud Almeida, 2017) no caso brasileiro. Isto é, para além da ordem deles, uma luta para que ela seja inscrita à ordem legal do país, pode-se dizer, uma moral pública de cunho privatista. Um ponto interessante que dá novos tons às disputas aqui elencadas do gênero, do Ensino Religioso Confessional, da Moral e Cívica e do Programa Escola sem Partido é a observação de Almeida de que, a despeito dos projetos serem ou não aprovados, eles têm apresentado um efeito catalizador e canalizador para gerar

\footnotetext{
${ }^{174}$ Pode-se citar em oposição aos conservadores evangélicos especificamente, grupos progressistas caracterizados pela defesa de minorias, postura crítica em relação aos extremistas e conservadores, leitura localizada da Bíblia. Atuam principalmente na internet, geralmente como coletivos e são evangélicos de diferentes faixas etárias e denominações (Vital da Cunha, Lopes e Lui, 2017, p. 125). Como também a linha progressista da Igreja Católica originária da Teologia da Libertação que segue atuando até hoje.
} 
resultados nas eleições proporcionais. Indo além, tais disputas no espaço público têm modificado a cultura escolar na ponta, na relação entre professor e alunos como vimos, ainda que de uma maneira tímida.

A família é colocada como o bastião da moralidade e se requer a sua prioridade na educação dos filhos, um único modelo numa infinidade de diferenças das famílias brasileiras. Essa defesa também foi uma tarefa da Igreja Católica no passado, que a colocava na frente do Estado ao se falar no direito de educar. Contemporaneamente, os grupos conservadores e/ou religiosos, principalmente evangélicos, têm requerido o direito das famílias sobre a educação moral, sexual e religiosa dos seus filhos. Esses últimos atuam de forma capilar, quando comparados à atuação institucional da Igreja Católica que, aos poucos, vai perdendo a cena quando temos a referência do seu passado hegemônico na influência da política educacional.

Não se pode negar ainda que pisamos em "solo católico" e a defesa do Ensino Religioso Confessional e o controle do avanço da "ideologia de gênero" nas escolas são duas das grandes pautas para a educação ${ }^{175}$. Ela só é menor quando comparada historicamente, mas ainda hoje é muito influente politicamente, não há dúvida. Embora essas disputas também sejam travadas internamente, o movimento das Católicas pelo Direito de Decidir e a Diversidade Católica ${ }^{176}$ ilustram bem isso, o que também ocorre com as igrejas evangélicas, por exemplo, a partir das denominações chamadas de inclusivas que fazem um contraponto no universo protestante $^{177}$.

As propostas de disciplinas como o Ensino Religioso ou a Moral e Cívica, que vez ou outra aparecem novamente, são apresentadas como formas de solucionar problemas, como o uso e o tráfico das drogas, a violência, a criminalidade e a ausência das famílias. São percebidas como "preventivas", mas uma solução

\footnotetext{
${ }^{175}$ Segundo Vital da Cunha, Lopes e Lui (idem), o deputado Givaldo Carimbão (PROS/AL), presidente da Frente Parlamentar Católica, declarou em 2015 que um dos temas prioritários era justamente a luta contra a inserção da discussão de gênero nas escolas.

${ }^{176}$ Definem-se como "um grupo de leigos católicos que procura conciliar a fé cristã e a diversidade sexual e de gênero, promovendo o diálogo e a reflexão, a oração e a partilha, compreendendo que a salvação de Cristo e sua mensagem são para todos, sem distinção (...)". Para saber mais, cf: http://www.diversidadecatolica.com.br/.

${ }^{177}$ Para saber mais, cf: OLIVEIRA, L. G. S. "O Senhor é meu pastor e ele sabe que eu sou gay": etnografando duas igrejas inclusivas na cidade de São Paulo. Dissertação de Mestrado, Pontifícia Universidade Católica do Rio de Janeiro, Departamento de Ciências Sociais, 2017. 118p.
} 
simples diante de questões tão complexas e que parecem não ter saída, ligadas em grande medida à nossa profunda desigualdade social, o que pode acabar colocando em segundo plano tais questões sociais e os problemas mais propriamente escolares que podem ser atacados por meio de ações mais efetivas. É como se tudo fosse resolver com a mudança na ética individual, algo que não se corrigiu nessa geração e irá ser corrigido na seguinte. Uma das pontuações possíveis é: qual o lugar que a escola deve ocupar na formação especialmente para os jovens?

A partir do cenário contemporâneo coloca-se em debate a percepção da escola como apenas parte do Estado ou como o encontro entre Estado e sociedade, isto é, o seu sentido de espaço público. Disputa-se qual o papel que a escola deve ocupar na reprodução social e/ou na sua transformação. Especialmente está em jogo a atuação dos professores: educadores ou especialistas, repassadores de conteúdo ou mediadores de diferentes conhecimentos. Daí a discussão da neutralidade, do que pode ser percebido como doutrinação, ideologia ou como ponto de vista, opinião versus a liberdade de cátedra do professor e a sua autonomia, a definição da sua ética profissional ${ }^{178}$. Disputa-se também a visão que se tem dos estudantes no processo de ensino e aprendizagem: passivos, "parte fraca" ou sujeitos ativos.

Com isso, é questionado o sentido da escola: um local voltado para apreensão do conhecimento científico e formação para o mercado de trabalho, um espaço para a socialização, um serviço a ser prestado, um direito a ser garantido. Visões essas que às vezes aparecem nos discursos dos atores sociais como excludentes ou como complementares. Traz-se à tona o lugar da escola, em especial a pública, nas sociedades democráticas, o seu papel ou não no combate aos preconceitos, na ampliação de visão de mundo apresentada inicialmente pela família. Disputam-se as fronteiras da escola em falar sobre os tabus existentes: a sexualidade, as discussões relacionadas ao gênero, as religiões. Isto é, o mundo dos alunos e alunas, não mais filhos, percebidos antes de mais nada enquanto adolescentes e jovens.

Outrossim, disputam-se os sentidos dados à Democracia. O processo de ampliação dos direitos que tem como marco a Constituição de 1988 é associado a crescente

\footnotetext{
${ }^{178}$ Sobre tal disputa a partir de um olhar jurídico ver tese: TRAVINCAS, A. C. T. A tutela jurídica da liberdade acadêmica no Brasil: a liberdade de ensinar e seus limites. Programa de PósGraduação em Direito. PUCRS, 2016. 300p.
} 
polarização política brasileira ao que se identificaria com a "esquerda", que é geralmente vinculada aos movimentos sociais, especialmente o feminista, a partidos específicos e são utilizados para explicar a "destruição da família". Mais recentemente, o discurso anticorrupção que vimos ser uma das motivações para proposições de disciplinas nas escolas públicas que tratem de ética, cidadania e civismo têm encontrado ressonância nas explicações de que "a esquerda brasileira usa, há anos, as escolas para doutrinar crianças e adolescentes e, por isso, é necessária uma ação para reverter o quadro" ${ }^{179}$.

Há uma coincidência temporal, por assim dizer, do processo ainda em curso de reconhecimento e afirmação dos direitos, especialmente das populações excluídas e minorias, como também da acusação de “doutrinação político-ideológica” nas escolas pelos professores. Isso se beneficia por uma percepção negativa dada à política contemporaneamente. Escola então não deveria ser um lugar de política como também de nada que fosse contrário às convicções dos pais e responsáveis dos estudantes. Embora se perceba, e pudemos ver nos exemplos empíricos, tudo isso adentra os seus muros inclusive pelos próprios alunos, adolescentes e jovens, que questionam, querem saber dos mais variados assuntos e têm nos professores uma referência.

\footnotetext{
${ }^{179}$ Essa é uma fala do deputado Lincoln Portela (PRB/MG) em uma das audiências públicas sobre o Programa Escola sem Partido. Disponível em: http://www2.camara.leg.br/camaranoticias/noticias/EDUCACAO-E-CULTURA/534255VEREADORES-DE-SAO-PAULO-E-DA-BAHIA-DEFENDEM-PROJETO-DA-ESCOLA-SEMPARTIDO.html Acesso em: 07 mar. 2018.
} 


\section{5 \\ Conclusão}

A laicidade institucional no Brasil, definida no período de proclamação da República, não significou o fim da influência da Igreja Católica no Estado, mas foi um momento inaugural para que se iniciassem as disputas no então nascente campo educacional brasileiro. Antes disso, essa instituição monopolizava o ensino, uma vez que essa era uma de suas funções no pacto colonial por meio da atuação dos jesuítas, o que continuou, não sem algumas tensões, durante o Império. $O$ catolicismo popular cheio de práticas sincréticas constituiu-se enquanto elo de um povo que se formava e teve nesse compartilhamento ${ }^{180}$ a gênese para a constituição de sua identidade nacional.

Concomitantemente, o novo momento levou, de um lado, a Igreja Católica a retomar a sua oficialidade por meio do processo de romanização e, de outro, a incessante busca de afastamento da sua influência na educação, primeiro pelos positivistas e posteriormente pelos seus herdeiros, os Pioneiros da Escola Nova como vimos no capítulo dois. No entanto, a sua força na sociedade dava credenciais para que essa instituição defendesse publicamente as suas demandas para a educação brasileira. Estava em jogo a continuidade da hegemonia católica ou o esvaziamento do religioso no espaço público. Embora já se pudesse observar a presença protestante que também possuía um projeto educacional e de sociedade, mas ainda não representava uma ameaça ao domínio católico.

O projeto para a modernização do Brasil passava pela expansão da escola pública. O projeto de "recatolização" do povo brasileiro nos moldes da Santa Sé também passava por essa instituição, daí a constante defesa do Ensino Religioso e aos poucos ganhava força a "fé na educação" trazida pelos primeiros missionários protestantes. Por outro lado, a formação de uma elite dirigente que tomasse contato com os valores religiosos católicos ou protestantes parecia também ser uma via de acesso para influenciar politicamente a constituição de uma sociedade futura pautada por preceitos cristãos, o que justificava a expansão das escolas

\footnotetext{
${ }^{180}$ No período da escravidão e posteriormente até pelo menos a primeira metade do século XX, os escravos negros e seus descendentes não tinham escolha, essa era a única forma de conseguir que alguns elementos de sua cultura original mantivessem vivos. Apesar da influência ter sido mútua não pode perder de vista as relações de poder aí imbricadas.
} 
confessionais. As católicas como uma "saída" encontrada, já que o ensino agora era laico, num período em que educação para a oficialidade católica significava também uma educação religiosa, e as protestantes como um dos principais programas de conversão. A primeira vez que se fazia a defesa da escola pública como um direito de todos e dever do Estado, uma escola que fosse laica e gratuita poderia ser um problema para o projeto de sociedade católico de então. Apenas no final dos anos 1950 e início dos anos 1960 começa a haver uma pressão interna de grupos de leigos e de parte do clero para um olhar focado na realidade brasileira, especialmente educacional, que ainda tinha um grau de analfabetismo muito grande nesse período.

Com a Ditadura Militar, ganhou força novamente a ala conservadora tanto da Igreja Católica como também entre os protestantes. A “ordem moral” funcionou como uma âncora para a manutenção da sociedade, como já havia ocorrido especialmente durante a Ditadura do Estado Novo. O Ensino Religioso continuava e, além dessa disciplina, retomou-se a matéria de Moral e Cívica nas escolas públicas. Até aí, tem-se a velha disputa em relação à escola: Igreja Católica atuando fortemente versus grupos secularizados.

A Constituição de 1988 representou um novo paradigma. A secularização da sociedade brasileira estava em curso e a Igreja Católica deixou de ser uma das únicas religiões que tinham a possibilidade de atuar no espaço público. Ou seja, a histórica relação entre essa instituição e Estado, a constituição da identidade nacional calcada por um catolicismo sincrético e uma sociedade ainda maciçamente católica tinham feito com que a influência política desta religião persistisse. Ocorreu, no entanto, que sua influência passou a ser dividida em fins do século XX e início do XXI por uma cada vez maior diversidade de religiões na medida em que elas cresciam em adeptos Brasil afora. A sociedade brasileira estava em processo de mudança, e, assim segue, no que tange à adesão religiosa, cada vez menos católica e mais diversa, mais protestante, especialmente mais pentecostal e também mais sem declaração a qualquer denominação religiosa institucional. Além disso, a própria Igreja Católica havia mudado a sua atuação a partir do Vaticano II passando a reconhecer o direito à liberdade religiosa. E não mais pautar a construção de uma 
sociedade nos moldes cristãos de uma maneira tão explícita como pudemos observar em relação à disputa pela política educacional ao longo do capítulo dois.

A exemplo do que historicamente ocorreu com o catolicismo, também havia acontecido uma virada na atuação pentecostal e de algumas denominações evangélicas que passaram a atuar mais fortemente no espaço público, especialmente na mídia e na política. Desse modo, pela primeira vez o pluralismo religioso foi um dos pontos fundamentais para a constituição da cidadania, deixando para trás o antigo sincretismo hierárquico. E a laicidade institucional construída anteriormente para a regulação dos direitos e deveres da Igreja Católica, como pontuou o primeiro capítulo, nesse novo momento de mudança no campo religioso brasileiro, pôde ser questionada. Sua instituição foi imprescindível a partir da Proclamação da República, como também ocorreu na América Latina, para que se iniciasse o processo de afirmação da diversidade religiosa brasileira mesmo que ainda pequena, mas já existente. Entretanto, é a consolidação do pluralismo religioso muito tempo depois que leva finalmente à defesa da laicidade para além de um dispositivo jurídico, como um valor social. O momento atual é o da disputa de sentido que deve ser dado à laicidade e/ou neutralidade religiosa do Estado brasileiro e também a definição dos limites e dos parâmetros para a cooperação entre Estado e religião previstos na Constituição. A Ação Direta de Inconstitucionalidade sobre o Ensino Religioso Confessional foi uma recente oportunidade de explicitação dos possíveis significados destes conceitos.

Católicos continuam a atuar no espaço público, mas protestantes de diferentes vertentes incluídas nas tradições históricas e pentecostais também se fazem mais presentes do que nunca. Além deles, novos atores da sociedade civil diversificam tal disputa. Tudo isso fica muito claro quando se observa as atuais disputas que se dão no campo moral, dos valores, condutas e atitudes no espaço escolar, também no que tange ao currículo quando se quer instituir determinado tipo de Ensino Religioso ou falar ou não falar sobre gênero e diversidade sexual dentro de sala de aula como vimos no capítulo três. Cada vez mais o que está em jogo é a "disputa das almas" dos estudantes, especialmente dos adolescentes que cursam o segundo segmento do Ensino Fundamental nas escolas públicas brasileiras. 
A Igreja Católica tenta manter sua hegemonia simbólica na educação retomando a discussão histórica do Ensino Religioso de uma forma atualizada e aciona diferentes entidades para defender a vertente confessional. Todavia, chama atenção a visibilidade dos políticos do legislativo federal que fazem parte das bancadas evangélicas ou querem se aproximar desse eleitorado quando adotam pautas que inicialmente não são suas, como o Escola sem Partido, mas que se alinham ao discurso da defesa da moral e do direito privado das famílias em relação à educação dos filhos em detrimento da atuação do Estado por meio da escola. A Igreja Católica, em muitos momentos, de protagonista na disputa, passou a ser coadjuvante. Na outra ponta, revezam-se novos e outros não tão novos assim grupos secularizados ligados aos movimentos sociais como o feminista e o LGBT ou da própria academia como o Observatório da Laicidade da Educação (OLÉ) da Universidade Federal do Rio de Janeiro (UFRJ), por exemplo. Ou ainda entidades que representam um diálogo inter-religioso como o FONAPER ${ }^{181}$ e que defendem a educação pública desde ONGs a movimentos e organizações sociais.

Outra dimensão em que as disputas aparecem é a própria escola pública na sua relação entre professores e alunos. São várias as realidades possíveis. Embora seja preciso destacar as situações de intolerância religiosa que geralmente possuem como alvos os estudantes identificados com as religiões afro-brasileiras e os principais autores estudantes e funcionários evangélicos, mas não só, também os sem religião que ocorrem em diferentes contextos. A ecologia do lugar em que a escola está situada é um fator que pode influenciar em muito a configuração dos seus atores. Esse foi o caso do trabalho de campo realizado que, apesar de ter sido feito num caráter exploratório, já demonstra uma singularidade e nos coloca para pensar.

Por se tratar de uma escola pública municipal localizada numa área de maior poder aquisitivo da cidade do Rio de Janeiro e por atender a um público que mora em sua esmagadora maioria em uma favela específica, apresentou a seguinte relação: alunos que se destacam como evangélicos e professores que se diferenciam a partir do pertencimento ao "solo" católico tradicional. Ou seja, uma geração que cresceu ainda num período de hegemonia dessa religião. Como vimos em outro exemplo,

\footnotetext{
${ }^{181}$ Apesar de englobar especialmente representantes de religiões cristãs.
} 
isso já não acontece numa escola pública localizada na Baixada Fluminense em que a maioria dos funcionários era evangélica e por isso trazia à tona esse pertencimento, em outra escola pública no Recife onde a presença do catolicismo nas atividades culturais era forte a ponto dos alunos evangélicos por meio de suas famílias demandarem por reconhecimento.

Além disso, na escola pesquisada, notou-se que há entre os professores o esforço de ensinar aos seus alunos o que compreendem por valores que podem ter uma maior, menor ou nenhuma relação com a adesão religiosa do próprio professor, quando ela existe. No geral, não há um consenso quanto a isso, tais ensinamentos partem muito da subjetividade dos professores, que compreendem fazer parte de seu papel de educadores falar sobre como ser e agir. Dão-se de uma forma intuitiva, na medida em que situações específicas ocorrem e há uma oportunidade pedagógica.

Em comum nas duas dimensões de análise há uma preocupação com a construção moral dos jovens. Algumas vezes contrapondo-se a um mundo fora da família e da escola como sendo hostil, com violência e drogas e também seletivo, do qual tais estudantes devem ser protegidos. Desse modo, acredita-se no fator positivo da religião na vida deles e isso aparece entre os professores. Em outros contextos de pesquisa também trazidos havia uma expectativa de que a religião fosse "salvar" os alunos do mundo hostil de que falávamos, como da indisciplina escolar, por exemplo. Há também uma atualização da "crise de valores" tão enunciada pelos católicos anteriormente, a crise de uma sociedade que se modernizava e apresentava novos moldes de família e novas relações de trabalho. A proteção dos jovens requerida no caso dos projetos de lei contemporâneos pesquisados se extrema, colocam-se contra tudo o que for diferente de uma conduta moral ensinada pelos seus pais ou responsáveis.

O que está em jogo atualmente não é a retirada das religiões no espaço público, mas a regulação da sua presença. Isso só se tornou possível por conta da constituição da cidadania a partir da ideia de direito à diferença, ao reconhecimento delas. É o pluralismo religioso que faz com que se institua tal interpretação da Constituição brasileira e um novo comportamento dos atores e das instituições tanto no âmbito da arena política, como no próprio "chão da escola". A novidade é que o 
reconhecimento e o ganho de visibilidade dos evangélicos possibilitou questionar antigas naturalizações.

Nesse sentido, o Estado contemporaneamente passa a ser um garantidor do pluralismo religioso e para tal deve reconhecer a diversidade de religiões desde as mais institucionalizadas e com mais poder, até as menos, mas que devem ter igual possibilidade de atuar no espaço público se assim quiserem, apesar de essa ser uma tarefa complexa. É o que também defende Regina Novaes (2012) quando chama a atenção para o significado do Estado laico na sua visão: a defesa por este Estado da diversidade religiosa, um processo que é relacional e que, para além da perspectiva do respeito e da valorização, traz à tona a diversidade como um direito.

De outra monta, as próprias religiões enquanto instituições da sociedade civil e constituidoras de culturas também passam a possuir responsabilidades na medida em que atuam publicamente. O respeito mútuo e aos diferentes grupos, principalmente às minorias, é um deles. É importante também levar em conta as suas diferenças internas, não as tratar como um todo homogêneo, é por aí que se iniciam processos de mudanças, atualizações e diálogos. Há um papel educativo das próprias religiões em propagar ou não preconceitos, discriminações ou intolerâncias. Um papel que é político, mas pode se manifestar na vida das pessoas individualmente como algo crucial, que também aparece no ambiente escolar, na relação de estudantes uns com os outros e entre professores e aqueles.

A nova disputa que se institui no campo educacional - nas práticas de professores, gestores, alunos e famílias e também em relação ao currículo oficial - se dá com novos atores. Diferentes grupos da sociedade civil mais ou menos institucionalizados defendem a ausência de relação do Estado brasileiro com as religiões com a justificativa do Estado laico ou o reconhecimento delas numa outra perspectiva de laicidade; a Igreja Católica ainda disputa sua hegemonia simbólica de forma institucional, mas não mais com a força de uma sociedade brasileira que reconhece na sua cultura apenas o catolicismo com o status de religião; e as igrejas evangélicas, que possuem em comum a sua pluralidade apenas, cruciais para esse novo momento, tornam-se presentes e tem sido protagonistas na reforma moral brasileira que está em curso. Agem de modo a influenciar as tomadas de decisão 
com base em sua moralidade, nem sempre em concordância, já que sua atuação se dá geralmente de maneira orgânica, por isso, consegue ser mais capilar.

No que tange à relação entre Estado e Religião, de certa forma, testemunhamos, ao contrário do que se poderia imaginar de antemão, um aprofundamento democrático. Novos atores no espaço público implicam maior representatividade de diferentes vozes, nem sempre antes ouvidas. Ao mesmo tempo em que impulsionam novas organizações numa maneira de reagir diante de tal realidade para criação e defesas de diferentes demandas, podendo impedir o despotismo da maioria. Há muitos grupos que se orientam por diferentes religiões e também outros tantos que atuam de maneira secularizada, todos eles podendo se associar ou disputar suas pautas. Há ainda as atuações individuais que se dão a partir das crenças e critérios de justiça de cada um. Se existe uma frente parlamentar evangélica e uma outra católica apostólica romana, haverá também uma em defesa dos povos tradicionais de matriz africana; se existe o Programa Escola sem Partido, haverá também o Movimento Educação Democrática e por aí vai. O importante é que todos "pisem no solo" democrático.

É inegável também que signifique um acirramento das disputas, o que sem dúvida pode ser bastante profícuo e um grande desafio. Isso se pensarmos na Democracia enquanto o lugar do conflito para a construção de consensos que levam a novos conflitos e novos consensos e assim sucessivamente, um processo que é contínuo, de construção como um sistema de governo, também como uma cultura. Isso também demonstra uma passagem no caso brasileiro de uma lógica social conciliatória para uma voltada para o conflito, principalmente ao que tange às demarcações de identidades. E a discussão do que deve ser ensinado na escola, a partir das atitudes, comportamentos, falas e também do próprio conteúdo pelos professores e professoras ao redor do Brasil, recoloca questionamentos enquanto sociedade: que se pense, por uma via, o que se tem de valores que nos são comuns e, por outra, quais são as diferenças que nos formam e que devem constar no currículo escolar. A escola pública aparece como o lugar de excelência de abertura para o reconhecimento, o conhecimento e o diálogo das diferenças tratadas não como tabus, mas como objetos de disciplinas e como aspectos das realidades dos estudantes, esses, percebidos enquanto sujeitos. Como realizar tal diálogo nos 
diferentes espaços é o que permanece em aberto. Não se pode perder de vista, insisto, é a relação da escola pública com a Democracia. Algo que não está dado e precisa por isso mesmo ser defendido, como lembrou Marcelo Burgos (2014).

A Constituição de 1988 explicita que a educação é uma tarefa do Estado e da família que deve ser feita em colaboração com a sociedade. Logo, ocorre num regime de mais ou menos complementaridade, contribuição, também concorrência e disputa. Ela não fala, no entanto, da proeminência de uma entidade sobre a outra. Embora saibamos que há uma separação clara, pelo menos constitucionalmente e analiticamente, do que é mundo privado em relação ao que pertence ao público. Cada vez mais, no entanto, tais fronteiras são atenuadas ${ }^{182}$. Uma vez que muitas das pautas dos movimentos sociais identitários, por exemplo, demandam por regulações e direitos que adentram às casas das pessoas e às vidas das famílias e também visam a mudar práticas e costumes enraizados nas relações sociais marcadamente assimétricas. A escola pública, por sua vez, não pode ser percebida apenas como braço do Estado, é também o encontro com a sociedade, daí que decorrem as disputas. Assim, é preciso que se construa "o lugar público da escola na vida brasileira" (idem, p. 9). As recentes discussões relacionadas ao currículo que vimos no capítulo três são um passo para isso, uma forma de trazer à tona a agenda da escola pública brasileira novamente.

Retomam-se os velhos objetivos da instituição escolar e o dos professores em particular: o do ensino, no sentido da apreensão de habilidades e ferramentas para a compreensão do mundo e possibilitar a entrada na universidade e/ou no mercado de trabalho; e o da educação, numa perspectiva de formar as novas gerações a viver em sociedade. Isto é, apresentar aos estudantes o mundo público, para além das interpretações particulares vindas do ambiente familiar. Pensar nessas duas tarefas como interdependentes, indispensáveis e igualmente importantes é crucial para que no Brasil a escola pública ganhe ares de um lugar de construção de uma sociedade democrática (idem). Todavia, é preciso também diferenciar as duas funções e aprofundá-las no dia a dia das salas de aula. Há certa dificuldade de professores em se perceberem também enquanto educadores na prática. Muitas vezes preferem se

\footnotetext{
${ }^{182}$ Embora historicamente no Brasil, a distinção entre o público e o privado nunca tenha sido tão clara, vê-se pelos trabalhos clássicos do início da Sociologia brasileira.
} 
resguardar no rótulo de apenas especialistas em uma determinada disciplina e reclamar às famílias dos seus alunos, "educação vem de casa". Esse também é um pensamento compartilhado no senso comum e o Programa Escola sem Partido, por exemplo, é um dos grupos que advoga por essa perspectiva.

Outras tantas, como é o caso dos professores entrevistados da escola municipal Cartola, há uma tentativa por parte deles de conversarem com os estudantes sobre determinados valores que subjetivamente acreditam ser importantes. Relacionamse geralmente às formas de agir, comportar-se e a cultivar alguns sentimentos específicos etc. Porém, tal divisão muitas vezes é utilizada como uma via de atuação que privilegia o lado educador em detrimento do ensino de conteúdos, não houve como saber se esse era o caso da escola pesquisada. Uma vez que falamos da educação escolar de crianças e adolescentes que, em geral, possuem muitas dificuldades em sala de aula, por conta dos mais variados fatores já exaustivamente trabalhados pela literatura e sobre os quais não se nutre tantas expectativas de sucesso escolar. Alguns professores então focam numa relação mais próxima de aconselhamentos e/ou suporte emocional e afetivo, por exemplo, justificando-se na ideia de que "falta atenção em casa". Poderíamos nos questionar sobre os resultados e desempenhos dos estudantes das escolas públicas brasileiras, que ainda não são satisfatórios para se pensar numa educação no seu sentido mais amplo, a realidade ainda é tão precária e são tantos os problemas que parecem prioritários. Não deveria se priorizar o básico?

Não há dúvida quanto a importância da escola no ensino de habilidades e competências especificas que dão credenciais para a atuação no mercado, mas o seu sentido educativo pode não ser tão lembrada assim de primeira, especialmente numa sociedade como a brasileira bastante individualista e competitiva em que o mercado educacional destaca a importância da primeira função. No entanto, ela é vital. Alain Touraine (1997) afirma que é a função educação que encoraja a diversidade cultural de seus alunos e favorece atividades que formam e afirmam a sua personalidade individual (idem, p. 363). Uma escola pública voltada para crianças e adolescentes vistos antes de mais nada enquanto sujeitos de direitos é aquela que consegue aproximar os aspectos do mundo dos seus alunos. Isso, compreendendo as suas diferenças, valorizando-as, e desigualdades, buscando 
corrigi-las, com a linguagem e as ferramentas do conhecimento científico que fazem parte da constituição da instituição escolar no seu fundamento. E que levam à autonomia dos indivíduos e resguardam também a autonomia da própria instituição escolar contra possíveis arbítrios (idem, p. 370). A escolarização de qualidade enquanto direito compõe os dois aspectos que devem estar presentes e interligados na formação de professores, no cotidiano da escola e nos currículos oficial e oculto.

A escola republicana francesa, que inspirou o sistema educacional brasileiro, principalmente a partir do olhar dos Pioneiros, é, para Durkheim (2012), a instituidora do social. Isso, na medida em que desenvolve um conjunto de estados físicos, intelectuais e morais exigidos pela sociedade em geral e específicos a que cada um irá desenvolver. Com isso, a tarefa educacional que primeiramente poderia ser pensada é o direito da família na esfera privada, passa a caber também ao Estado, para Durkheim. Tal instância torna-se responsável pela definição dos princípios comuns que irão constar dos currículos. Daí a função da escola de reprodutora do social e que também se modifica na medida em que novas necessidades surgem na sociedade. O professor é o porta-voz da sociedade na escola republicana e o seu objetivo é a construção de igualdade, por isso uma de suas tarefas é a de deixar para trás tudo o que há de específico em cada um, a igualdade nesse caso também é de partida, e construir uma nova base pautada no universalismo da cultura nacional. Por isso é tão forte a associação entre escola republicana e laicidade no contexto francês, como também já vimos.

Fazendo a crítica desse modelo que se encontra em crise atualmente, Touraine defende a ideia de laicidade como uma forma de salvaguarda contra Estados que não aceitam a prática de religiões ou opiniões minoritárias. A escola pública laica contemporaneamente, na sua visão, assume a heterogeneidade e a diversidade em detrimento de uma unidade de tipo comunitária. O seu ponto de partida é o reconhecimento da diversidade social e cultural do público que adentra a escola. Guardadas as devidas diferenças de contexto, isso também ocorreu no Brasil principalmente a partir do período de massificação escolar iniciado na década de 1970, que representou a entrada dos mais pobres e a saída da classe média para as escolas privadas. Esse período coincidiu com o início da mudança mais decisiva no 
campo religioso brasileiro, a chegada e crescimento das igrejas pentecostais entre as camadas populares.

Para Touraine, as antigas separações entre vida pública e privada da qual a laicidade originalmente é devedora e da instrução pública e familiar tem efeitos negativos, pois favorecem as crianças e adolescentes dos meios socialmente estabelecidos e destrói a capacidade de formação do sujeito. Sua defesa é o da escola que tem por finalidade a formação dos indivíduos, a escola do Sujeito voltada para a formação e o reforço da "liberdade do sujeito pessoal" (idem, p. 358), ou seja, levar em conta as procuras individuais e coletivas dos indivíduos; que dá importância central à diversidade histórica e cultural e ao reconhecimento do Outro (idem, p. 359); e que busque corrigir ativamente as desigualdades, tendo uma visão realista e não idealizada das situações coletivas e pessoais. Daí a escola ter um papel ativo de democratização. Uma preocupação próxima a de Dewey (1936) que vê na escola, um dos principais espaços para uma práxis democrática, por isso a escola deve ser ela mesma produtora de consensos, mais do que apresentar consensos externos a ela como defendia Durkheim (Burgos, 2014). Desse modo, as experiências dos jovens são trazidas para o ambiente escolar e o professor ganha outro papel, o de mediador de diferentes conhecimentos.

Em contraposição a Durkheim, Touraine afirma que "é necessário renunciar a uma educação-para-a-sociedade. Em vez de arrancar a criança a uma parte de si mesma, a mais intima, para transformar em civilizado (...), é necessário recompor a sua personalidade (...)" (Touraine, 1997, p. 362). Muitas vezes, a ideia de laicidade é acionada para reduzir a tarefa educacional à transmissão de conhecimentos e há uma recusa em encarregar-se dos problemas dos estudantes, geralmente muito difíceis de resolver. No contexto brasileiro isso também é comum, e o fato da escola pública estar isolada institucionalmente é um grande agravante dessa situação. "Não se deve falar sobre", "essa não é a minha função", "é preciso ser neutro" são algumas das falas de professores para tangenciar determinados assuntos ou mesmo mantê-los como tabus. Ao mesmo tempo, tais profissionais estão exatamente no meio das disputas entre Estado, famílias e sociedade e têm sido muito pressionados por todos os lados. Touraine fala da importância da independência da atuação dos professores, que deveria ser tal como a dos magistrados. 
Pensando na primazia da formação dos sujeitos, Touraine defende o ensino das religiões na escola pública francesa:

A escola deve, pelo contrário, entrar naquilo que constitui uma parte importante da personalidade dos alunos. O ensino das religiões. Das suas crenças como da sua história, não é certamente um atentado à laicidade, pelo contrário, é o silencio imposto sobre as realidades religiosas que é um atentado inaceitável ao espirito de objetividade e de verdade de que a escola laica se reclama e que não deverá mais estar ausente de escolas ditas religiosas que é necessário proteger ainda mais a clausura diretamente da clausura comunitária (idem, p. 363).

É claro que tal defesa se dá num contexto recente de conflitos étnicos e religiosos nos países europeus, por conta da sua população neorrepublicana que se volta especificamente aos cidadãos europeus mulçumanos. A virada que pode ser considerada extrema de autores como esse e tantos outros franceses que tem se debruçado na crise da escola republicana, especialmente a crise da forma escolar, pode ser explicada por conta do caráter sagrado que tomou tal instituição na França. Não é sem motivo, porém, que a igualdade de partida defendida por Durkheim e pelos formuladores da escola republicana no século XIX se deu com tanta veemência. Ela se fazia necessária para contrapor o modelo dual anterior que se pautava na formação de elites, não que isso não tenha acontecido posteriormente, mas no resguardo da chave do mérito. Outrossim, a defesa da laicidade se deu para que enfim a Igreja Católica cessasse a sua influência no Estado francês, principalmente no ensino. O momento atual é outro e requer da escola que se reconheçam as diferenças dos jovens que adentram aos seus muros, e possa agir de maneira mais equitativa.

No Brasil, os conflitos não são tão demarcados assim, mas eles existem e têm se mostrado cada vez mais concentrados. Por aqui quase nunca houve silêncio das religiões dominantes, houve sim silenciamentos históricos de determinadas crenças e grupos. Uma forma do Estado ser o garantidor da diversidade religiosa de que falávamos pode ser justamente pela via da escola pública. Se essa é uma questão, dentre tantas outras como a política, a sexualidade por exemplo, que está no dia a dia dos adolescentes, pode-se trazer tal tema. Nunca, no entanto, esquecendo-se da razão da existência da instituição escolar, a educativa. Por isso há necessidade de regulação do currículo, por exemplo, para a disciplina facultativa de Ensino Religioso. O papel da escola é o de ampliar a visão de mundo dos estudantes, trazer 
novos pontos de vista por meio de diferentes conhecimentos. Nesse sentido, a interpretação do STF em relação ao Ensino Religioso Confessional foi uma oportunidade perdida, decidida na contramão do que as pesquisas que falam sobre Ensino Religioso Confessional versam. Uma vez que, na linha do que diz Touraine, chancelou-se a "clausura comunitária", ou como colocaria Richard Sennet (2012), reforçou-se "tribalismos" e comportamentos do tipo "nós contra eles". A escola, no entanto, deve se apropriar das questões que dizem respeito à vida de seus alunos e agir contra discriminações, preconceitos e intolerâncias. Uma maneira possível é tratando no currículo do "outro", não apenas do "nós".

A aposta de Touraine é a de que conhecendo o "outro" por meio da escola é mais possível que se reconheça a importância da garantia dos direitos de cada um. Sennet (idem), imbuído da preocupação com a cooperação num mundo cada vez mais "tribal" se pergunta se a experiência direta com o outro poderia enfraquecer estereótipos. Duas situações de pesquisa diferentes trazidas chegam a resultados opostos: o caso de brancos e negros que conviveram durante a Segunda Guerra Mundial e os primeiros passaram a ser menos racistas e a constatação de outro autor sobre o afastamento da vizinhança de pessoas que tiveram a experiência direta da diversidade. Ou seja, os resultados podem ser diversos. Para Sennet, "o tribalismo une solidariedade com aqueles que se parecem e agressão aos que são diferentes" (Sennet, idem, p. 14). A desigualdade social é um dos primeiros potenciais desativadores da cooperação e aumenta as distâncias entre as pessoas. A sua conclusão mais à frente é a de que a verdadeira cooperação prescinde de saber quem é o outro na sua subjetividade, apenas é preciso que se saiba da sua abertura para cooperar. A falta de entendimento recíproco não deve ser um impedidor de nos relacionar uns com os outros.

A escola é um lugar de mediação de culturas, de trocas dialógicas, de convivência, do aprender a viver juntos. A diferenciação feita por Sennet de simpatia e empatia - a primeira como sendo "sei perfeitamente como se sente" e a segunda "estou atento a você" - é um potencial exercício não só da escola em relação aos seus alunos, mas dos adultos em geral em relação aos jovens. Especialmente em relação ao segundo sentimento, porque desperta o indivíduo para uma conversa dialógica na qual a discussão não resulta na identificação de um terreno comum, mas na 
atenção e receptividade em relação aos outros, na capacidade de ouvir bem e atentar de perto para o que as pessoas dizem e interpretar antes de responder resultando numa conversa mais cooperativa. Pode-se conscientizar mais de seus próprios pontos de vista e ampliar a compreensão recíproca. Olhar para fora gera um vínculo social melhor do que partir da ideia de que os outros estão refletidos em nós mesmos. Esse olhar para fora pode ser dado num incentivo da própria escola.

Logo, a escola deixa de ser o lugar apenas da transmissão de conhecimento e passa a ser o lugar da troca, da comunicação intercultural, do diálogo. Touraine destaca a importância da expressão oral ou escrita e da sua compreensão. E Sennet da escuta atenta, da abertura para cooperar. Torna-se imprescindível olhar para os estudantes e compreendê-los como sujeitos ativos nas suas diversas dimensões, desde o lugar onde vivem, a situação social, de gênero e raça, da idade e da fase da vida em que estão, como também da religião que professam, da família que possuem, das histórias particulares e coletivas que trazem consigo. E principalmente para o tipo de relação que se trava com eles no dia a dia. Isto é, "desmassificar" a instituição escolar. Mais do que os consensos a escola pode ser o lugar do ensino das controvérsias, ou seja, os variados pontos de vista sobre algo, as diferentes visões de mundo, a pluralidade de opiniões. Dessa forma, busca-se a formação de autonomia entre os alunos, o que requer de um lado uma formação mais especifica para professores e de outro a consolidação do lugar público da escola pública no Brasil. Embora se aposte na criação de bens comuns, uma tarefa modesta, mas ainda assim de igual importância á trazida por Sennet, da busca pela compreensão recíproca. Uma agenda de pesquisa futura é o foco nos próprios adolescentes a partir da busca do que compreendem como importante que a escola possa abordar, como também a trajetória de estudantes e de suas famílias e a relação que estabelecem com as religiões e a escola. 


\section{6 \\ Referências bibliográficas}

AÇÃO EDUCATIVA ACESSORIA, PESQUISA E INFORMAÇÃO (Org.). A ideologia do movimento Escola sem Partido: 20 autores desmontam o discurso. São Paulo: Ação Educativa, 2016. 168p.

ALMEIDA, R. A onda quebrada: evangélicos e conservadorismo. Dossiê Conservadorismo, Direitos, Moralidades e Violência, Cadernos Pagu, n. 50, não paginado. 2017. Disponível em: <http://dx.doi.org/10.1590/18094449201700500001>. Acesso em: 23 jan. 2018.

Dez anos do "chute na santa": a intolerância com a diferença In: SILVA, V. G. (Org.). Intolerância religiosa: impactos do neopentecostalismo no campo religioso afro-brasileiro. São Paulo: Editora da Universidade de São Paulo, 2007. p. 171-189.

; BARBOSA, R. J. Transição religiosa. In: ARRETCHE, M. (Org.). Trajetórias das desigualdades: como o Brasil mudou nos últimos 50 anos. 1 ed. São Paulo: Editora Unesp; CEM, 2015. p. 335-367.

AMARAL, D. P. Ética, moral e civismo: difícil consenso. Cadernos de Pesquisa, v. 37, n. 131, p. 351-369, mai./ago. 2007. Disponível em: < http://www.scielo.br/pdf/\%0D/cp/v37n131/a0737131.pdf>. Acesso em: 10 jan. 2017.

ARIÈS, P. História Social da Criança e da Família. Tradução de Dora Flasckman. $2^{\circ}$ ed. Rio de Janeiro: Zahar, 2012. 196 p.

ASAD, T. A construção da religião como uma categoria antropológica. Tradução de Bruno Reinhardt e Eduardo Dullo. Cadernos de campo, São Paulo, n. 19, p. 1-384, 2010.

AZZI, R. A favor da família contra a educação sexual. In: ; GRIP, V. K. História da Igreja no Brasil: ensaio de interpretação a partir do povo, t. II/3-2: terceira época: 1930-1964. Petrópolis, RJ: Vozes, 2008. p. 142-152.

Escola católica versus ensino leigo e protestante. In:

GRIP, V. K. História da Igreja no Brasil: ensaio de interpretação a partir do povo, t. II/3-2: terceira época: 1930-1964. Petrópolis, RJ: Vozes, 2008. p. 153-163.

Educação cívica e militar. In: ; GRIP, V. K. História da Igreja no Brasil: ensaio de interpretação a partir do povo, t. II/3-2: terceira época: 1930-1964. Petrópolis, RJ: Vozes, 2008. p. 296-305.

A Escola Nova e a educação tradicional. In: ; GRIP, V. K. História da Igreja no Brasil: ensaio de interpretação a partir do povo, t. II/3-2: terceira época: 1930-1964. Petrópolis, RJ: Vozes, 2008. p. 306-326.

BARROS S. P. Escravos, libertos, filhos de africanos livres, não livres, 
pretos, ingênuos: negros nas legislações educacionais do XIX. Educação Pesquisa, v. 42, n. 3, p. 591-605, São Paulo, jul./set. 2016. Disponível em: http://www.scielo.br/pdf/ep/v42n3/1517-9702-ep-42-3-0591.pdf. Acesso em: 28 fev. 2017.

BASILE, M. O. N. C. As questões religiosa e militar. In: LINHARES, M. Y. História Geral do Brasil. 9 ed. Rio de Janeiro: Campus, 1990. p. 277-281.

BASILIO A. L. Base Nacional Comum Curricular é alvo de grupos religiosos. Carta Capital. 10 out. 2017. Disponível em: http://www.cartaeducacao.com.br/reportagens/base-nacional-comum-curricular-ealvo-de-grupos-religiosos/. Acesso em: 25 fev. 2018.

$\begin{array}{lllll} & \text { Enem: Justiça derruba critério que zera redação que viola direitos } \\ \text { humanos. } & \text { Carta } \quad \text { Capital. } 25 & \text { out. } 2017 . & \text { Disponível em: }\end{array}$ http://www.cartaeducacao.com.br/reportagens/enem-justica-derruba-criterio-quezera-redacao-que-viola-direitos-humanos/. Acesso em: 08 mar. 2018.

BRANCHINI, D. S. A propósito dos 125 anos da lei áurea: inserção negra no segmento evangélico. Revista da Faculdade de Teologia da Igreja Metodista, v. 18, n. 1, 1 sem. 2013. São Bernardo do Campo, SP : Editeo / Umesp. p. 13-24

BRASIL. Constituição (1988). Brasília: Senado Federal, Coordenação de Edições Técnicas, $2016 . \quad$ Disponível em: <https://www2.senado.leg.br/bdsf/bitstream/handle/id/518231/CF88_Livro_EC91 _2016.pdf> . Acesso em 02 de março de 2018. 496p.

Lei de Diretrizes e Bases da Educação. Lei 9.394, de 20 de desembro de 1996. Disponível em: http://www.planalto.gov.br/ccivil_03/Leis/L9394.htm . Acesso em 02 de março de 2018.

Parâmetros Curriculares Nacionais: introdução aos parâmetros curriculares nacionais. Secretaria de Educação Fundamental. Brasília: MEC/SEF, 1997. Disponível em: <http://portal.mec.gov.br/seb/arquivos/pdf/livro081.pdf>. Acesso em: 02 mar. 2018. 126p.

Lei 10.639, de 9 de janeiro de 2003. Disponível em: <http://www.planalto.gov.br/ccivil_03/leis/2003/L10.639.htm> . Acesso em: 02 mar. 2018. <https://www.planalto.gov.br/ccivil_03/_ato2007-2010/2008/lei/111645.htm> . Acesso em: 02 mar. 2018.

- Diretrizes Curriculares Nacionais Gerais da Educação Básica. Ministério da Educação. Secretaria de Educação Básica. Diretoria de Currículos e Educação Integral. Brasília: MEC, SEB, DICEI, 2013. Disponível em: $<$ http://portal.mec.gov.br/index.php?option=com_docman\&view=download\&alia $\mathrm{s}=15548$-d-c-n-educacao-basica-nova-pdf\&category_slug=abril-2014pdf\&Itemid=30192> . Acesso em: 02 mar. 2018. 562p. 
$\begin{array}{ccc}\text { Disponível } & 1 \text { versão Base Nacional Comum Curricular. } 16 \text { de set. } 2015 . \\ \text { em: } & <\text { http://historiadabncc.mec.gov.br/documentos/BNCC- }\end{array}$ APRESENTACAO.pdf>. Acesso em: 20 fev. 2018. 302p.

. $2^{\mathrm{a}}$ versão Base Nacional Comum Curricular. 3 mai. 2016. Disponível em: $\quad\langle$ http://historiadabncc.mec.gov.br/documentos/bncc-2versao.revista.pdf $>$. Acesso em: 20 fev. 2018. 652p.

. $3^{\mathrm{a}}$ versão Base Nacional Comum Curricular. abr. 2017.

. Base Nacional Comum Curricular. 06 abr. 2017. Disponível em: $<$ http://portal.mec.gov.br/index.php?option=com_docman\&view=download\&alia s=79601-anexo-texto-bncc-reexportado-pdf-2\&category_slug=dezembro-2017pdf\&Itemid $=30192>470 p$.

BERGER, P. A dessecularização do mundo: uma visão global. Religião e Sociedade. Rio de Janeiro, 21(1): 9-24, 2000.

BIRMAN, P. Introdução. In: (Org.) Religião e espaço público. São Paulo: Attar, 2003. p. 11-24.

. Percursos afro e conexões sociais: negritude, pentecostalismo e espiritualidades. In: TEIXEIRA, F; MENEZES, R. (Orgs.). As religiões no Brasil: continuidades e rupturas. Petrópolis: Vozes, 2006. p. 189-205.

Só Deus resolve: Desafios evangélicos à ordem mundana. In: BURITY, J.; ANDRADE, P. Religião e Cidadania. (Orgs.). 1 ed. São Cristóvão (SE): Editora UFS; Recife (PE): Fundação Joaquim Nabuco, 2011. p. 17-33.

BLANCARTE, R. América Latina: Entre pluri-confesionalidad y laicidad. Civitas, v. 11, n. 2, p. 182-206. Porto Alegre, mai/ago, 2011. Disponível em: < http://revistaseletronicas.pucrs.br/ojs/index.php/civitas/article/view/9644/6738>. Acesso em:03 abr. 2017.

BOMENY, H. M. Quando os números confirmam impressões: desafios na educação brasileira. CPDOC, p. 1-29. Rio de Janeiro, 2003.

BRANCHINI, D. S. A propósito dos 125 anos da lei áurea: inserção negra no segmento evangélico. Caminhando: Revista da Faculdade de Teologia da Igreja Metodista, v. 18, n. 1, p. 13-24, 1 sem. São Bernardo do Campo, 2013.

BRANDÃO, C. R. Ser católico: dimensões brasileiras - um estudo sobre a atribuição de identidade através da religião. In: SACHS, V. et al. Brasil \& EUA: religião e identidade nacional. Rio de Janeiro: Graal, 1988. p.27-58.

BRÍGIDO, C. STF decide que escolas públicas podem ter ensino confessional. O Globo. 27 st. 2017. Disponível em: Acesso em: 10 mar. 2018. Disponível em: https://oglobo.globo.com/sociedade/educacao/stf-decide-que-escolas-publicaspodem-ter-ensino-confessional-21878145\#ixzz5CF8BbdMr. Acesso em: 10 mar. 2018. 
BRUM, E. Escola Sem Pinto. El País. 17 abr. 2017. Disponível em: https://brasil.elpais.com/brasil/2017/04/17/opinion/1492435392_872941.html . Acesso em: 14 fev. 2018.

BURGOS, M. B. Introdução - Afirmação institucional da escola democrática e o mundo do aluno. In: (Org.). A escola e o mundo do aluno: estudos sobre a construção social do aluno e o papel institucional da escola. 1 ed. Rio de Janeiro: Garamond, 2014. p. 9-35.

; ROSSI, L. O valor da Educação Escolar para as famílias: confronto entre a percepção dos responsáveis e o senso comum escolar. In: (Org.). A escola e o mundo do aluno: estudos sobre a construção social do aluno e o papel institucional da escola. 1 ed. Rio de Janeiro: Garamond, 2014. p. 45-62.

Base Nacional Comum: o currículo no centro do debate público. Boletim CEDES, p. 18-26. ago/dez, 2015. Disponível em: http://www.cis.pucrio.br/cis/cedes/bn/setembro_dezembro_2015/3-base-nacional-comum_marceloburgos.pdf . Acesso em: 25 fev. 2018.

CAFARDO, R. Base Curricular inclui temas como gênero e sexualidade em área de ensino religioso. $O$ Estado de São Paulo. Disponível em: http://educacao.estadao.com.br/noticias/geral,base-curricular-inclui-temas-comogenero-e-sexualidade-em-area-de-ensino-religioso,70002110265. Acesso em: 24 fev. 2018.

; TOLEDO, L. F. Ensino religioso na base curricular ainda terá discussão à parte. O Estado de São Paulo. 16 dez 2017. Disponível em: http://educacao.estadao.com.br/noticias/geral,ensino-religioso-na-base-curricularainda-tera-discussao-a-parte,70002122041 . Acesso em: 09 mar. 2018.

CANCIAN. N. Ministério tira 'identidade de gênero' e 'orientação sexual' da base curricular. Folha de São Paulo. 06 abr. 2017. Disponível em: http://www1.folha.uol.com.br/educacao/2017/04/1873366-ministerio-tiraidentidade-de-genero-e-orientacao-sexual-da-base-curricular.shtml . Acesso em: 25 fev. 2018.

CÂMARA DOS DEPUTADOS. Projetos de Lei. Disponível em: <http://www2.camara.leg.br/>. Acesso em: 22 fev. 2018.

CAMBI, F. História da Pedagogia. Tradução de Álvaro Lorencini. São Paulo, Fundação Editora Unifesp, 1999. 701p.

CAMPOS, R. B. C. Pesquisando o invisível: percursos metodológicos de uma pesquisa sobre uma pesquisa sobre sociabilidade infantil e diversidade religiosa. Teoria e Sociedade, $\mathrm{n}^{\circ}$ 17.1, janeiro/junho, 2009 p.148-175.

. Um estranho no ninho: uma experiência protestante em escola laica no Recife. In: BURITY, J; ANDRADE, P. (Orgs.). Religião e Cidadania. 1ed. São Cristóvão (SE): Editora UFS; Recife (PE): Fundação Joaquim Nabuco, 2011. p. 157-176. 
; MARIZ, C. L. O pentecostalismo muda o Brasil? Um debate das Ciências Sociais brasileiras com a Antropologia do Cristianismo. In: SCOTT, P.; CAMPOS, R. \& PEREIRA, F.(Org). Rumos na Antropologia no Brasil e no mundo: geopolíticas disciplinares, Recife, ABA publicações e editora da UERJ, 2014, p. 191-214.

CAPITANIO, A. M. Gênero e crenças religiosas: sentidos da docência entre professoras do ensino fundamental I. Tese de Doutorado, Programa de PósGraduação em Educação, Faculdade de Educação da Universidade de São Paulo, 2014. 170p.

CAPUTO, S. G. Educação nos Terreiros: e como a escola se relaciona com as crianças de candombe. 1 ed. Rio de Janeiro: Pallas, 2012. 296p.

CÂMARA NOTÍCIAS. Ministério busca equilíbrio para abordagem de gênero na base curricular. 06 jun. 2017. Disponível em: http://www2.camara.leg.br/camaranoticias/noticias/EDUCACAO-ECULTURA/536038-MINISTERIO-BUSCA-EQUILIBRIO-PARAABORDAGEM-DE-GENERO-NA-BASE-CURRICULAR.html . Acesso em: 08 mar. 2018

Relator do Escola sem Partido diz que proposta não tem motivação religiosa. 15 fev. 2017. Disponível em: http://www2.camara.leg.br/camaranoticias/noticias/EDUCACAO-ECULTURA/523211-RELATOR-DO-ESCOLA-SEM-PARTIDO-DIZ-QUEPROPOSTA-NAO-TEM-MOTIVACAO-RELIGIOSA.html. Acesso em: 07 mar. 2018.

$\begin{array}{ccc} & \text { Projeto sobre escola sem partido divide opiniões de debatedores. } 08 \\ \text { fev. } & 2017 . & \text { Disponível }\end{array}$ http://www2.camara.leg.br/camaranoticias/noticias/EDUCACAO-ECULTURA/522852-PROJETO-SOBRE-ESCOLA-SEM-PARTIDO-DIVIDEOPINIOES-DE-DEBATEDORES.html . Acesso em: 07 mar. 2018.

Vereadores de São Paulo e da Bahia defendem projeto da Escola sem Partido. 09 mai. 2017. Disponível em: http://www2.camara.leg.br/camaranoticias/noticias/EDUCACAO-ECULTURA/534255-VEREADORES-DE-SAO-PAULO-E-DA-BAHIADEFENDEM-PROJETO-DA-ESCOLA-SEM-PARTIDO.html Acesso em: 07 mar. 2018.

CARVALHO, E. A. G. Religião e sexualidade: um entrave para a educação sexual nas escolas. $40^{\circ}$ Encontro annual da ANPOCS. Caxambu, 2016.

CARVALHO, M. Exclusão de gênero do Plano Nacional de Educação é retrocesso, diz educador. IG. 26 dez. 2015. Disponível em: http://ultimosegundo.ig.com.br/educacao/2015-12-26/exclusao-de-genero-doplano-nacional-de-educacao-e-retrocesso-diz-educador.html . Acesso em: 03 mar. 2018. 
CATÓlICAS PELO DIREITO DE DECIDIR; IBOPE INTELIGÊNCIA. Percepções sobre aborto e educação sexual. 2017.

CAVALIERI, A. M. O mal-estar do ensino religioso nas escolas públicas. Cadernos de Pesquisa, São Paulo, n. 131, p. 303-332. mai/ago, 2007. Disponível em: < http://www.scielo.br/pdf/cp/v37n131/a0537131.pdf>. Acesso em 20 jan. 2017.

Quando o Estado pede socorro à religião. Revista Contemporânea de Educação, v. 1, n. 2, não paginado. Rio de Janeiro. 2006. Disponível em: < https://revistas.ufrj.br/index.php/rce/article/view/1503/1352>. Acesso em: 20 jan. 2017.

COMUNICAÇÕES DO ISER. Ensino Religioso no Estado do Rio de Janeiro: Registros e Controvérsias, n. 60. Rio de Janeiro: ISER, 2004. 154p.

CONSELHO NACIONAL DO MINISTÉRIO PÚBLICO. Roteiro de atuação do Ministério Público: estado laico e ensino religioso nas escolas públicas. Brasília, $2016 . \quad$ Disponível em: <http://www.crianca.mppr.mp.br/arquivos/File/publi/cnmp/roteiro_atuacao_ensin o_religioso_nas_escolas_publicas.pdf >. Acesso em: 10 fev. 2018.

COUTO, M. Magno Malta retira de tramitação no Senado projeto do Escola Sem Partido. O Globo. 21 nov. 2017. Disponível em: https://oglobo.globo.com/sociedade/magno-malta-retira-de-tramitacao-no-senadoprojeto-do-escola-sem-partido-22092617\#ixzz5CFC7Cd5D . Acesso em: 05 mar. 2018.

CUNHA, V. C.; LOPES, P. V. L. Religião e política: uma análise da atuação de parlamentares evangélicos sobre direitos das mulheres e de LGBTs no Brasil. Rio de Janeiro: Fundação Heinrich Böll, 2012. 230p.

; LUI, J. Reavaliando categorias sociais: como pensar os evangélicos na sociedade e na política no Brasil contemporâneo. In: Religião e Política: medos sociais, extremismo religioso e as eleições 2014. Rio de Janeiro: Fundação Heinrich Böll; Instituto de Estudos da Religião, 2017. p. 111-134.

CUNHA, L. A. A educação na concordata Brasil-Vaticano. Educação \& Sociedade, Campinas, v. 30, n. 106, p. 263-280, jan.-abr. 2009.

Educação e religiões: a descolonização religiosa da escola pública. Belo Horizonte: Mazza Edições, 2013. 122p.

. A luta pela ética no ensino fundamental: religiosa ou laica? Cadernos de Pesquisa, v. 39, n. 137, p. 401-419, mai/ago. 2009. Disponível em: < http://www.scielo.br/pdf/cp/v39n137/v39n137a05.pdf>. Acesso: 10 jan. 2017.

CURY, C. R. J. Ideologia e Educação Brasileira. São Paulo: Cortez e Moraes, 1978. 201p. 
DALLABRIDA, N. Das escolas paroquiais às PUCs: República, recatolicização e escolarização. In: STEPHANOU, M.; BASTOS, M. H. C. (Orgs.). Histórias e Memórias da educação no Brasil, v. III. Petrópolis, RJ: Vozes, 2005. p. 77-86.

DE OLHO NOS PLANOS. Entenda a polêmica sobre a discussão de gênero nos planos de educação. EBC. 07 jul. 2016. Disponível em: <http://www.ebc.com.br/educacao/2015/07/entenda-por-que-e-importantediscutir-igualdade-de-genero-nas-escolas>. Acesso em: 03 mar. 2018.

DEWEY, J. Democracia e educação: introdução à filosofia da educação. Tradução de Godofredo Rangel e Anísio Teixeira. 3. ed., São Paulo: Nacional, 1959. 416p.

DOMINGOS, M. F. N.. Escola e Laicidade: o modelo francês. Interações - Cultura e Comunidade, v. 3 n. 4, p. 153-170, 2008. Disponível em: < http://www.ce.ufpb.br/ppgcr/arquivos/producoes/producao_4.pdf $>$. Acesso em: 22 jan. 2017.

DROOGERS, A. A Religiosidade. Mínima Brasileira. Religião e. Sociedade, Rio de Janeiro, 14/2, p. 62-86, 1987.

DIP, A. Existe “ideologia de gênero"? Agência Pública. 30 ago. 2016. Disponível em: <https://apublica.org/2016/08/existe-ideologia-de-genero/ >. Acesso em: 03 mar. 2018.

DUARTE, L. F. D. Aonde caminha a moralidade? Cadernos Pagu, n. 43, p. 1927, jul/dez. 2013. Disponível em: < http://www.scielo.br/pdf/cpa/n41/03.pdf>. Acesso em: 06 abr. 2017.

DURKHEIM, E. Educação e sociologia. Petrópolis, RJ: Vozes, 2012. 120p.

FERREIRA, P.; MARIZ R. CNE retira gênero e orientação sexual da Base Curricular. O Globo. 12 dez. 2017. Disponível em: $<$ https://oglobo.globo.com/sociedade/educacao/cne-retira-genero-orientacaosexual-da-base-curricular-22179063\#ixzz5CF1qZLWVStest> . Acesso em: 25 fev. 2018.

FILHO, P. V.; MENDONÇA, A. G. Introdução ao Protestantismo no Brasil. Edições Loyola: São Paulo, 1990. 270p.

FISCHMANN, Roseli. Ainda o ensino religioso em escolas públicas: subsídios para a elaboração de memória sobre o tema. Revista Contemporânea de Educação. v. 1, n. 2, não paginado. Rio de Janeiro, 2006. Disponível em:< https://revistas.ufrj.br/index.php/rce/article/view/1506/1355>. Acesso em: 03 abr. 2017.

FREYRE, G. Casa-grande \& Senzala: formação da família brasileira sob o regime da economia patriarcal. 51 a ed. Global Editora: São Paulo, 2006. 727p.

GIUMBELI, E. Crucifixos Invisíveis: polêmicas recentes no Brasil sobre símbolos religiosos em recintos estatais. Anuário Antropológico, v. 10, n. 1, p. 75-102. 2011. Disponível em: <http://journals.openedition.org/aa/1019>. Acesso em: 04 abr. 2017. 
. Religião, Estado, modernidade: notas a propósito de fatos provisórios. Estudos avançados, v. 18, n. 52, p. 47-62. 2004.

A presença do religioso no espaço público: modalidade no Brasil. Religião e Sociedade, Rio de Janeiro, v. 28, n. 2, p.80-101. 2008.

. Ensino religioso e assistência religiosa no Rio Grande do Sul. Civitas, Porto Alegre, v. 11, n. 2, p. 259-283, mai/ago. 2011.

O acordo Brasil-Santa Sé e as relações entre estado, sociedade e religião. Ciencias Sociales y Religión/Ciências Sociais e Religião, a. 13, n. 14, p. 119-143. Porto Alegre, set. 2011.

; CARNEIRO S. S. Religião nas escolas públicas: questões nacionais e a situação no Rio de Janeiro. Revista Contemporânea de Educação (publicação eletrônica da Faculdade de Educação da UFRJ), n. 2, não paginado. 2006.

Um projeto de cristianismo hegemônico. In: SILVA, V. G. (Org.). Intolerância religiosa: impactos do neopentecostalismo no campo religioso afrobrasileiro. São Paulo: Editora da Universidade de São Paulo, 2007. p. 149-169.

GUYON, R.; B., Falaize. Entretien avec Philippe Portier. La controverse est la condicition de la production toujurs provisoire et dépassable, de valeurs. In: L'école et les valeurs. Charlie, et après? Diversité, n. 182, 4 trimestre, p. 7-40. 2015.

HOLANDA, S. B. Raízes do Brasil. 26ª ed. São Paulo: Companhia das Letras, 1995.

INDOLI, R. O que aconteceu com as propostas da Escola sem Partido pelo Brasil. Nexo Jornal. 05 set. 2017. Disonível em: https://www.nexojornal.com.br/expresso/2017/09/05/O-que-aconteceu-com-aspropostas-da-Escola-sem-Partido-pelo-Brasil Acesso em: 05 mar. 2018.

INSTITUTO BRASILEIRO DE GEOGRAFIA E ESTATÍSTICA. Censo Demográfico 2010: Características gerais da população, religião e pessoas com deficiência. Rio de Janeiro, 2010. p. 1-215.

LEITE, L.; COLÉN, R. Entenda o que o Projeto Escola Livre muda no ensino estadual em Alagoas. G1 Alagoas. 28 abr. 2016. Disponível em: http://g1.globo.com/al/alagoas/noticia/2016/04/entenda-o-que-o-projeto-escolalivre-muda-no-ensino-estadual-em-alagoas.html . Acesso em: 05 mar. 2018.

LIMA, D. Educação, Igreja e ideologia: uma análise sociológica da Lei de Diretrizes e Bases. Rio de Janeiro, Francisco Alves, 1978. 139p.

LUI, J. A. Entre crentes e pagãos: ensino religioso em São Paulo. Cadernos de Pesquisa, v. 37, n. 131, p. 333-349, mai/ago. 2007. Disponível em: < http://www.scielo.br/pdf/cp/v37n131/a0637131.pdf>. Acesso em: 05 abr. 2017.

MACHADO, M. Aluno é barrado em escola municipal do Rio por usar guias do candomblé. G1 Rio, Rio de Janeiro, 02 set. 2014. Disponível em: 
<http://g1.globo.com/rio-de-janeiro/noticia/2014/09/aluno-e-barrado-em-escolamunicipal-do-rio-por-usar-guias-do-candomble.html>. Acesso em: 24 jan 2018.

MACHADO, M. D. C. Carismáticos e pentecostais: adesão religiosa na esfera familiar. Campinas, SP: Autores Associados; São Paulo, SP: ANPOCS, 1996. $221 \mathrm{p}$.

MAFRA, C. Números e narrativas. Debates do NER, Porto Alegre, a. 14, n. 24, p. 13-25, jul./dez. 2013. Disponível em: <http://seer.ufrgs.br/index.php/debatesdoner/article/view/43557/27413>. Acesso em: 04 abr. 2017.

Os Evangélicos. Rio de Janeiro: Jorge Zahar Ed., 2001. Disponível em: $\quad<$ http://www.teoriaedebate.org.br/index.php?q=materias/politica/osevangelicos-e-politica-reflexoes-necessarias-sobre-o-brasil-de-hoje > Acesso em: 04 abr. 2017.

MAGGIE, I. Menina apedrejada: fanatismo e intolerância religiosa no Rio de Janeiro. G1 Rio, Rio de Janeiro, 18 jun. 2015. Disponível em: <http://g1.globo.com/pop-arte/blog/yvonne-maggie/post/menina-apedrejadafanatismo-e-intolerancia-religiosa-no-rio-de-janeiro.html $>$. Acesso em: 24 jan 2018.

MAGNANI, J. G. C. A Etnografia como prática e experiência. Horizontes Antropológicos, Porto Alegre, ano 15, nº 32, julho/dezembro. 2009. p. 129-156.

MANIFESTO dos educadores - Mais uma vez convocados. In: MAGALDI, A. M.; GONDRA, J. G. (Orgs.). A reorganização do campo educacional no Brasil: manifestações, manifestos e manifestantes. Rio de Janeiro: 7 letras, 2003. p. 157177.

MANIFESTO dos Pioneiros da Educação Nova. A reconstrução educacional no Brasil. In: MAGALDI, A. M.; GONDRA, J. G. (Orgs.). A Reorganização do Campo Educacional no Brasil: manifestações, manifestos e manifestantes. Rio de Janeiro: 7 Letras, 2003. p. 125-146.

MARCÍLIO, M. L. Origens 1554-1870. In: História da escola em São

Paulo e no Brasil. São Paulo: Imprensa Oficial do Estado de São Paulo: Instituto Fernand Braudel, 2005. p. 3-92. . O "século" da escola 1870-1990. In: História da escola em São Paulo e no Brasil. São Paulo: Imprensa Oficial do Estado de São Paulo: Instituto Fernand Braudel, 2005. p. 93-336.

MARIANO, R. Laicidade à brasileira: Católicos, pentecostais e laicos em disputa na esfera pública. Civitas, v. 11, n. 2, p. 238-258. Porto Alegre, mai/ago, 2011. Disponível em:< http://revistaseletronicas.pucrs.br/ojs/index.php/civitas/article/view/9647/6619>. Acesso em: 04 abr. 2017.

Expansão e ativismo político de grupos evangélicos conservadores: Secularização e pluralismo em debate. Civitas, v. 16, n. 4, p. 710-728, Porto Alegre, 
out/dez.

2016.

Disponível

em:

<http://revistaseletronicas.pucrs.br/ojs/index.php/civitas/article/view/9647/6619>.

Acesso em: 23 jan. 2018.

- Sociologia do crescimento pentecostal no Brasil: um balanço.

Perspectiva Teológica, a. 43, n. 119, p. 11-36. Belo Horizonte, jan/abr, 2011.

Disponível

em:

$<$ http://oldsociologia.fflch.usp.br/sites/oldsociologia.fflch.usp.br/files/Sociologia

$\% 20$ do\%20crescimento\%20pentecostal\%20no\%20Brasil.pdf >. Acesso em: 23 jan. 2018.

MARIZ, C. L.; MACHADO, M. D. C. Mudanças recentes no campo religioso brasileiro. Antropolítica. Niterói, n. 5, p. 21-43, 2 sem. 1998.

Secularização e dessecularização: comentários a um texto de Peter

Berger. Religião e Sociedade, Rio de Janeiro, v. 21, n. 1, p.25-39. 2000.

A religião no enfrentamento da pobreza no Brasil. Revista Crítica de Ciências Sociais, n. 33, p. 11-24, out. 1991.

MARIZ, R. Conteúdos sobre gênero e sexualidade na Base Curricular podem ficar para depois. O Globo. 07 dez. 2017. Disponível em: https://oglobo.globo.com/sociedade/educacao/conteudos-sobre-generosexualidade-na-base-curricular-podem-ficar-para-depois22178446\#ixzz5CF3bPSMw . Acesso em: 24 fev. 2018.

MARTIN, M. STF decide que escola pública pode promover crença específica em aula de religião. El País. 27 set. 2017. Disponível em: https://brasil.elpais.com/brasil/2017/08/31/politica/1504132332_350482.html . Acesso em: 10 mar. 2018.

MAZZI, C. Aluno é impedido de frequentar escola com guias de candomblé. 03 set. 2014. Disponível em: https://educacao.uol.com.br/noticias/2014/09/03/rjaluno-e-impedido-de-frequentar-escola-com-guias-de candomble.htm?cmpid=copiaecola. Acesso em: 14 fev. 2018.

MIRANDA, M. C. T. Educação no Brasil: Esboço de estudo histórico. Imprensa Universitária, Recife: 1966. 94p.

MINISTÉRIO PÚBLICO FEDERAL. Ação Direta de Inconstitucionalidade 9934. Disponível em:< http://redir.stf.jus.br/estfvisualizadorpub/jsp/consultarprocessoeletronico/Consulta rProcessoEletronico.jsf?seqobjetoincidente=3926392> Acesso em: 10 fev. 2018.

MONTERO, P. Introdução. In: (Org.). Religiões e controvérsias públicas: experiências, práticas sociais e discursos. São Paulo: Editora Terceiro nome, Campinas: Editora Unicamp, 2015. p. 11-26.

O Campo Religioso, Secularismo e a Esfera Pública no Brasil. Boletim CEDES, p. 1-7. out./dez., 2011. Disponível em:< http://www.cis.pucrio.br/cis/cedes/PDF/out_2011/campo.pdf>. Acesso em: 02 mai. 2017. 
Religião, laicidade e secularismo: um debate contemporâneo à luz do caso brasileiro. Cultura y Religión, v. II, p. 132-150. 2013. Disponível em: < $<$ https://religiaoeesferapublica.wordpress.com/2015/09/28/religiao-laicidade-esecularismo-um-debate-contemporaneo-a-luz-do-caso-brasileiro/>. Acesso em: 02 mai. 2017.

NOTÍCIAS STF. Ministro Roberto Barroso abre audiência pública sobre ensino religioso nas escolas públicas. 15 JUN. 2015. Disponível em:http://www.stf.jus.br/portal/cms/verNoticiaDetalhe.asp?idConteudo=293563 . Acesso em: 10 mar. 2018.

27 . STF conclui julgamento sobre ensino religioso nas escolas públicas. 2017. http://www.stf.jus.br/portal/cms/verNoticiaDetalhe.asp?idConteudo=357099 Acesso em: 10 mar. 2018.

NOVAES, R. Juventude, religião e espaço público: exemplos "bons para pensar" tempos e sinais. Religião e Sociedade, Rio de Janeiro, v. 32, n. 1, p. 184208. 2012. Disponível em: < http://www.scielo.br/pdf/rs/v32n1/a09v32n1.pdf>. Acesso em: 02 mai. 2017.

Os "evangélicos" e a política: reflexões necessárias sobre o Brasil de hoje. Teoria e Debate, ed. 158, 29 mar. 2017. Disponível em:< https://teoriaedebate.org.br/2017/03/29/evangelicos-e-a-politica-reflexaonecessaria/ > . Acesso em: 23 jan. 2018.

. Os jovens "sem religião": ventos secularizantes, “espírito de época”e novos sincretismos. Notas preliminares. Estudos avançados, v.18, n. 52, p. 321330, 2004.

O GLOBO. Paes recebe aluno barrado em escola no Rio por usar guia do candomblé. https://oglobo.globo.com/rio/paes-recebe-aluno-barrado-em-escolano-rio-por-usar-guia-do-candomble-13815666 . Acesso em: 14 fev. 2018.

OLIVEIRA, N. F. A repressão policial às religiões de matriz afro-brasileiras no Estado Novo (1937-1945). Dissertação de Mestrado. Programa de Pós-Graduação em História Social, Universidade Federal Fluminense, Niterói: 2015. 173p.

OLIVEIRA, R S. C. Intolerância religiosa na escola: uma reflexão sobre estratégias de resistência à discriminação religiosa a partir de relatos de memória de adeptos de Umbanda. Dissertação de Mestrado, Pontifícia Universidade Católica do Rio de Janeiro, Programa de Pós-Graduação em Serviço Social, Rio de Janeiro: 2014. 114p.

ORO, A. P.; PETROGNANI, C. A laïcité em questão: um comentário a um texto de Luca Diotallevi. Debates do NER, Porto Alegre, ano 16, n. 27, p. 51-61, jan./jun. 2015 .

PAIVA, A. R. Católico, protestante, cidadão: uma comparação entre Brasil e Estados Unidos. Rio de Janeiro: Centro Edelstein de Pesquisas Sociais, 2010. 232p. 
PAIVA. T. Conservadorismo e religião pautam debate sobre educação com secretário de SP. Carta Capital. 06 jun. 2016. Disponível em: http://www.cartaeducacao.com.br/reportagens/conservadorismo-e-religiaopautam-debate-sobre-educacao-com-secretario-de-sp/ . Acesso em: 09 mar. 2018.

PAVARINI. Em Manaus, alunos evangélicos se recusam a ler obras como "Macunaíma" e "Casa Grande Senzala", dizendo que os livros falam sobre "homossexualismo". 12 nov. 2012. Disponível em: http://www.pavablog.com/2012/11/12/em-manaus-alunos-evangelicos-serecusam-a-ler-obras-como-macunaima-e-casa-grande-senzala-dizendo-que-oslivros-falam-sobre-homossexualismo/. Acesso em: 09 dez. 2016.

PENNA, F. A. O Escola sem Partido como chave de leitura do fenômeno educacional. In: FRIGOTTO, G. (Org.). Escola "sem" partido: esfinge que ameaça a educação e a sociedade Brasileira. Rio de Janeiro: UERJ; LPP, 2017. p. $35-48$.

PIERUCCI, A. F. "Bye bye, Brasil" - o declínio das religiões tradicionais no Censo 2000. Estudos avançados, v.18, n.52, p. 17-28. São Paulo, set/dez., 2004. Disponível em: <http://dx.doi.org/10.1590/S0103-40142004000300003>. Acesso em: 01 mai. 2016.

Ciências Sociais e religião - A religião como ruptura. In: TEIXEIRA, F.; MENEZES, R. (Orgs.). As religiões no Brasil: continuidades e rupturas. Petrópolis, RJ: Vozes, 2006. p. 17-34.

PORTIER, P. A regulação estatal da crença nos países da Europa Ocidental. Religião e Sociedade. Rio de Janeiro, v. 31, n.2, p. 11-28. 2011.

PRANDI, R. Perto da magia, longe da política: derivações do encantamento no mundo desencantado. Novos Estudos, n. 34, p. 81-91. nov. 1992.

QUEIROZ, M. I. P. Identidade nacional, religião, expressões culturais: a criação religiosa no Brasil. In: SACHS, V. et al. Brasil \& EUA: religião e identidade nacional. Rio de Janeiro: Graal, 1988. p. 59-93.

RAMALHO, J. P. Prática Educativa e Sociedade: um estudo de Sociologia da Educação, Rio de Janeiro: Zahar, 1976. 183p.

RANQUETA J. C. A. Laicidade, Laicismo e secularização: esclarecendo os conceitos. Revista Sociais e Humanas. n.1, não paginado. 2008.

REINA, M. L. Pentecostalismo e questão racial no Brasil: desafios e possibilidades do ser negro na igreja evangélica. PLURAL, Revista do Programa de Pós-Graduação em Sociologia da USP, São Paulo, v.24, n.2. 2017. p. 253-275.

ROMANELLI, O. Fatores atuantes na evolução do sistema educacional brasileiro. In: . História da Educação no Brasil: (1930/1973). 34 ed. Petrópolis, RJ: Vozes, 2009. p. 33-46. 
Organização do ensino e o contexto sócio-político após 1930. In: História da Educação no Brasil: (1930/1973). 34 ed. Petrópolis, RJ:

Vozes, 2009. p. 127-192.

SANTOS, B. I. S. [et al.] (Org.). Intolerância religiosa no Brasil: relatório e balanço. Rio de Janeiro: Klíne: CEAP, 2016. 298p.

SENADO FEDERAL. Projetos de Lei do Senado. Disponível em: <https://www 12.senado.leg.br/hpsenado>. Acesso em: 21 fev. 2018

SENNETT, R. Introdução: o estado de espírito cooperativo. In:

Juntos: Os rituais, os prazeres e a política da cooperação. Rio de Janeiro, Record: 2012. p. 13-48.

Parte um: moldando a cooperação. In: Juntos: Os rituais, os prazeres e a política da cooperação. Rio de Janeiro, Record: 2012. p. 49-162.

SILVA, A. C. Laicidade versus Confessionalismo na escola pública: um estudo em Nova Iguaçu (RJ). Dissertação de Mestrado, Universidade Federal do Rio de Janeiro, Faculdade de Educação. Rio de Janeiro, 2013. 134p.

SILVA, M. E. Diversidade religiosa na escola pública: um olhar das manifestações populares dos ciclos festivos. Dissertação de Mestrado, Universidade Federal de Pernambuco CFCH, Programa de Pós-Graduação em Antropologia. Recife, 2011. 111p

; CAMPOS, R. B. C. Ciclos Festivos na escola pública e pluralismo religioso: conflitos e interações - um ensaio por uma abordagem teórico metodológica do estudo da festa no espaço escolar. Revista da FAEEBA Educação e Contemporaneidade, v. 20, n. 35, p. 31-40. Salvador, jan./jun, 2011. Disponível em: < http://testeocs.uneb.br/index.php/faeeba/article/view/420/363>. Acesso em: 14 mar. 2017.

SILVA, V. G. Prefácio ou Notícia de uma guerra nada particular: os ataques neopentecostais às religiões afro-brasileiras e aos símbolos da herança africana no Brasil. In: _ (Org.). Intolerância religiosa: impactos do neopentecostalismo no campo religioso afro-brasileiro. São Paulo: Editora da Universidade de São Paulo, 2007. p. 9-28.

Religião e identidade cultural negra: católicos, afrobrasileiros e neopentecostais. Cadernos de campo, n. 20, p. 295-303. São Paulo, 2011.

SOARES, W. Conheça o "kit gay" vetado pelo governo federal em 2011. Nova Escola. 012 fev. 2015. Disponível em:< https://novaescola.org.br/conteudo/84/conheca-o-kit-gay-vetado-pelo-governofederal-em-2011>. Acesso em: 05 mar. 2017.

TARDELI, B. Ministério Público do MS coagiu pais a irem em palestra com pregação religiosa. Carta Capital. 27 mai. 2017. Disponível em http://justificando.cartacapital.com.br/2017/05/27/ministerio-publico-do-mscoagiu-pais-irem-em-palestra-com-pregacao-religiosa/ . Acesso em: 27 mai. 2017. 
TAYLOR, C. Uma Era Secular. São Leopoldo, RS: Unisinos, 2010. 930p.

T. B. "O professor da minha filha comparou Che Guevara a São Francisco de Assis" El País. 25 jun. 2016. Disponível em: https://brasil.elpais.com/brasil/2016/06/23/politica/1466654550_367696.html . Acesso em: 04 mar. 2018.

TEIXEIRA, F. Campo religioso em transformação. In: CUNHA, C. V.; MENEZES, R. C. (Org.). Comunicações do ISER. 69. p. 34-45. set, Rio de Janeiro, 2014. Disponível em: < http://www.iser.org.br/site/wpcontent/uploads/2015/04/Comunica\%C3\%A7\%C3\%B5es-do-ISER69.compressed.pdf> Acesso em: 04 abr. 2017.

TOLEDO, L. F; CHADE, J. Relatores da ONU classificam 'Escola sem Partido' como 'censura'. O Estado de São Paulo. 13 abr. 2017. Disponível em: http://educacao.estadao.com.br/noticias/geral,relatores-da-onu-denunciam-escolasem-partido-e-classificam-projeto-de-censura,70001737530 . Acesso em: 08 mar. 2018.

TOURAINE, A. A escola do sujeito. In: Iguais e diferentes: poderemos viver juntos? Lisboa: Instituto Piaget, 1997. p. 353-382.

VALENTE, G. A. A presença oculta da religiosidade na prática docente. Dissertação de Mestrado, Programa de Pós-Graduação em Educação, Faculdade de Educação da Universidade de São Paulo, 2015. 120p

SETTON, M. G. J. Artigos sobre o campo religioso brasileiro e a religiosidade na escola pública. Anais do XIV Simpósio Nacional da ABHR Juiz de Fora, MG, 2015. p. 180-192. Disponível em: <http://www.abhr.org.br/plura/ojs/index.php/anais/article/viewFile/1002/845>. Acesso em: 05 abr. 2017.

VELHO, G. Observando o familiar. In: NUNES, Edson (org). A aventura sociológica: objetividade, paixão, improviso e método na pesquisa social. Rio de Janeiro: Zahar, 1978, p. 36-46.

WEBER, M. Parte III: Religião. In: Ensaios de Sociologia. $5^{\text {a }}$ ed. Rio de Janeiro: LTC, 1982. p. 189-252.

ZEFERINO, J. L. B. Entre diálogos e silenciamentos: o que dizem os professores sobre a religião no cotidiano das escolas? Dissertação de Mestrado, Pontifícia Universidade Católica do Rio de Janeiro, Programa de Pós-Graduação em Educação, Rio de Janeiro: 2016. 158p 